

\section{DISCLAIMER}

This report was prepared as an account of work sponsored by an agency of the United States Government. Neither the United States Government nor any agency Thereof, nor any of their employees, makes any warranty, express or implied, or assumes any legal liability or responsibility for the accuracy, completeness, or usefulness of any information, apparatus, product, or process disclosed, or represents that its use would not infringe privately owned rights. Reference herein to any specific commercial product, process, or service by trade name, trademark, manufacturer, or otherwise does not necessarily constitute or imply its endorsement, recommendation, or favoring by the United States Government or any agency thereof. The views and opinions of authors expressed herein do not necessarily state or reflect those of the United States Government or any agency thereof. 


\section{DISCLAIMER}

Portions of this document may be illegible in electronic image products. Images are produced from the best available original document. 


\section{NOTICE}

This report was prepared as an account of work. sponsored by the United States Government. Neither the United States nor the United States Energy Research \& Development Administration, nor any of their employees, nor any of their contractors, subcontractors, or their employees, makes any warranty, express or implied, or assumes any legal liability or responsibility for the accuracy, completeness or usefulness of any information, apparatus, product or process disclosed, or represents that its use would not infringe privately-owned rights

\section{NOTICE}

Reference to a company or product name does not imply approval or recommendation of the product by the University of California or the U.S. Energy Research \& Development Administration to the exclusion of others that may be suitable.

Printed in the United States of America

$$
\text { Available from }
$$

National Technical Information Service

U.S. Department of Commerce

5285 Port Royal Road

Springfield, VA 22161

Price Printed Copy $\$$, Microfiche $\$ \mathbf{3 . 0 0}$

\begin{tabular}{|c|c|c|c|}
\hline Page Range & Price. & Page Range & Price \\
\hline $001-025$ & S 3.50 & $326-350$ & 10.00 \\
\hline $026-050$ & 4.00 & $351-375$ & 10.50 \\
\hline $051-075$ & 4.50 & $376-400$ & 10.75 \\
\hline $076-100$ & 5.00 & $401-425$ & 11.00 \\
\hline $101-125$ & 5.50 & $426-450$ & 11.75 \\
\hline $126-150$ & 6.00 & $451-475$ & 12.00 \\
\hline $151-175$ & 6.75 & $476-500$ & 12.50 \\
\hline $176-200$ & 7.50 & $501-525$ & 12.75 \\
\hline $201-225$ & 7.75 & $526-550$ & 13.00 \\
\hline $226-250$ & -8.00 & $551-575$ & 13.50 \\
\hline $251-275$ & 9.00 & $576-600$ & 13.75 \\
\hline $276-300$ & 9.25 & $601-u p$ & $\cdots$ \\
\hline $301-325$ & 9,75 & & \\
\hline
\end{tabular}

Add $\$ 2.50$ for each additional 100 page increment from 601 to 1,000 pages; add $\$ 4.50$ for each additional 100 page increment over 1,000 pages: 


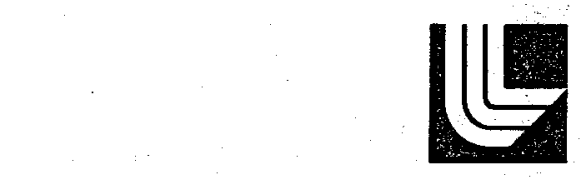

\section{LAWRENCE LIVERMORE LABORATORY}

University of Caltornia/Livermore, California/94550

\section{UCRE-50044-76-1 \\ IMPERIAL VALLEY ENVIRONMENTAL PROJECT: PROGRESS REPORT}

\section{Editors:}

Paul L. Phelps and Lynn R. Anspaugh

October 19,1976

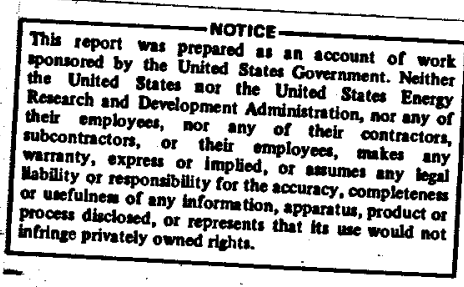





\section{Contents}

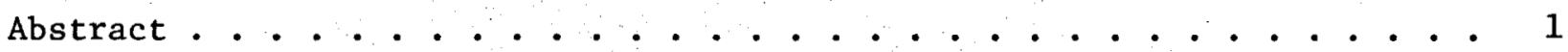

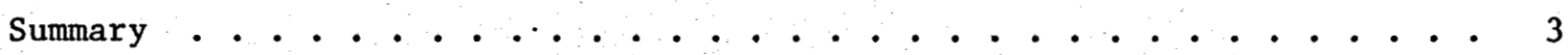

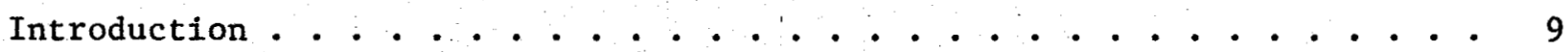

Imperial Valley Environmental Project (IVEP) Elements . . . . . . 16

Air Quality .................... 17

Water Quality ........................ 41

Ecosystem Quality ..................... 64

Subsidence and Seismicity ............. 75

Socioeconomic Effects ................... 93

Health Effects . . . . . . . . . . . . . 102

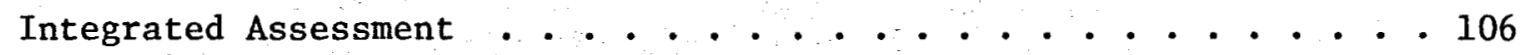

Supporting Activities . . . . . . . . . . . 174

Remote Sensing . . . . . . . . . . . . 175

Research Support Contracts ............... 182

Imperial Valley Environmental Project Advisory Panel . . . . . . . . 136

Imperial Valley Environmental Project Schedule . . . . . . . . . . 191 
$$
\pi
$$

\section{Imperial Valley Environmental Project}

Abstract 


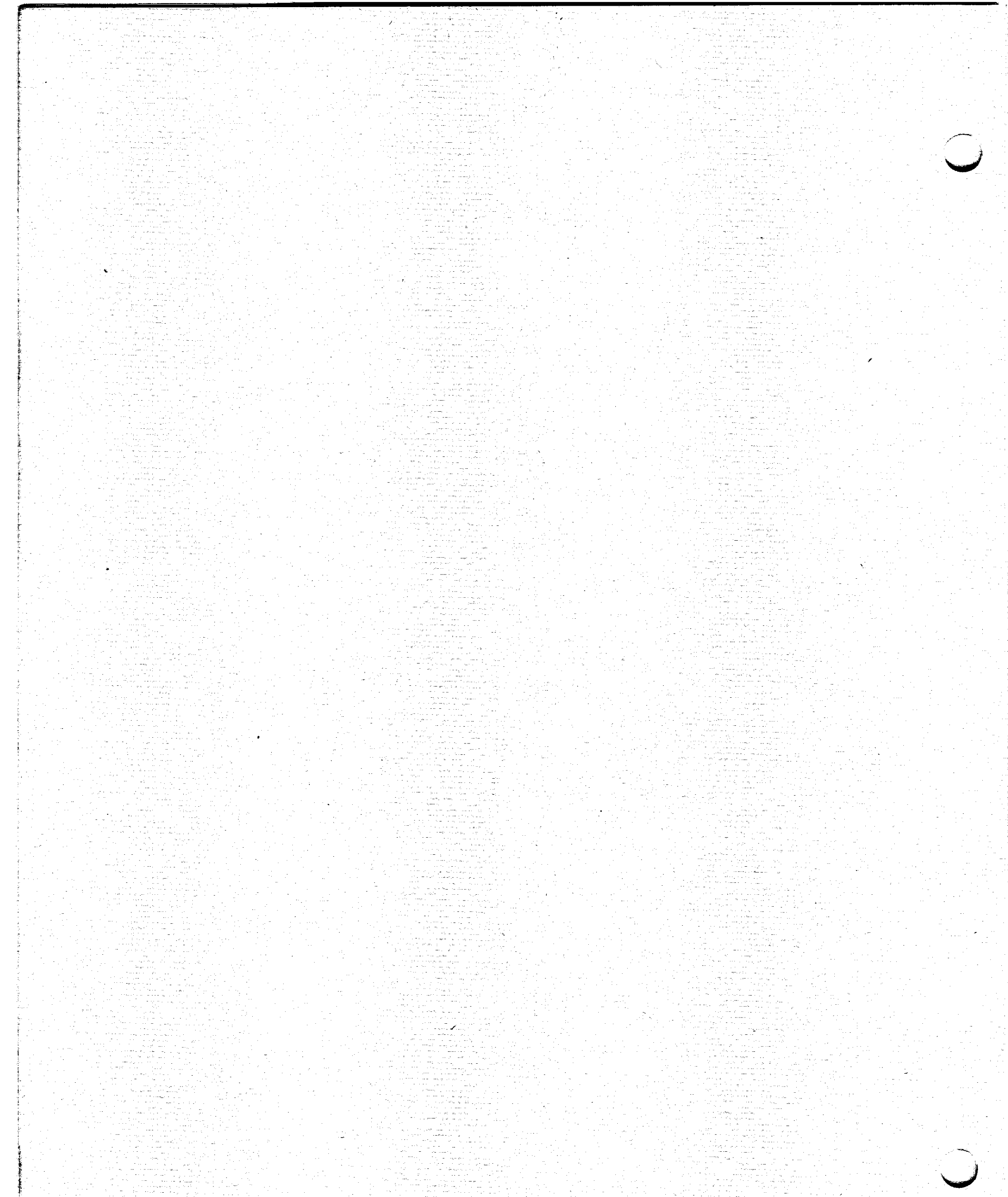




\title{
IMPERIAL VALLEY ENVIRONMENTAL PROJECT: PROGRESS REPORT
}

\author{
Abstract \\ The Imperial Valley Environmental \\ An integrated project (IVEP) was \\ Project (IVEP) was initiated by the \\ organized and consists of seven main \\ Assistant Administrator for Environ- \\ elements : \\ ment and Safety, Energy Research and \\ Development Administration (ERDA), to \\ - Air Quality \\ establish an environmental data base- \\ - Water Quality \\ line for the Imperial Valley and to \\ assess the potential environment im- \\ pact of future geothermal installations \\ in the Valley. The Lawrence Livermore \\ Laboratory (LLL) was requested by the \\ - Ecosystem Quality \\ - Subsidence and Seismicity \\ - Socioeconomic Effects \\ - Health Effects \\ Assistant Administrator for Environ- \\ ment and Safety to be the Lead \\ - Integrated Assessment \\ Laboratory to set up and manage the \\ environmental baseline program. \\ A summary of the progress in these \\ areas during the first year of this \\ project is presented.
}




\section{Imperial Valley Environmental Project}

\section{Summary}




\section{Summary}

AIR QUALITY

One of the potentially important impacts of large-scale development of geothermal resources within the Imperial Valley is degradation of air quality. Nearly all geothermal development schemes will release noncondensable gases to the atmosphere. These gases may contain $\mathrm{H}_{2} \mathrm{~S}$ and $\mathrm{NH}_{3}$.

A network consisting of six fixedlocation air-quality and meteorological monitoring stations is currently being installed in the Imperial Valley. They will be used to measure current levels of selected air pollutants and to characterize the atmospheric transport properties on a Va1ley-wide basis.

A major goal of the air quality element has been to evaluate the rate of emission of $\mathrm{H}_{2} \mathrm{~S}, \mathrm{CO}_{2}, \mathrm{H}_{2}, \mathrm{~N}_{2}, \mathrm{CH}_{4}$, and $\mathrm{C}_{2} \mathrm{H}_{6}$ from the operation of the San Diego Gas and Electric (SDGE)/

Energy Research and Development AdminIstration (ERDA) geothermal loop experimental facility at Niland. Source-term measurements have been made on a routine basls. Concentrations of $\mathrm{H}_{2} \mathrm{~S}$ have been found to vary between 1500 to $4900 \mathrm{ppm}$ by volume at the Niland facility.

Ambient baseline data and sourceterm information are being gathered and will be eventually used in atmospheric transport models to predict the annual average change in air quality throughout the entire Valley resulting from the operation of postulated geothermal power plants situated anywhere within the Valley.

\section{WATER QUALITY}

Development of geothermal resources in the Imperial Valley carries with it the possibility of contaminating surface and subsurface waters by geothermal brines. This could happen from injection into the ground of spent geothermal brines or by accidental releases. Because these brines are moderately to highly saline; the major effect would be an increase in salinity. A problem exists in differentlating any such contamination, because the surface water used in the Imperial Valley is rather highly mineralized from the Colorado River, and the agricultural practices used result in leaching of salts from the soils. It is conceivable that transient increases of salinity in drainage water resulting from agricultural practices could be confused with geothermal contamination.

To distinguish between geothermal fluids and other waters, extensive 
sampling networks have been established. Samples are being routinely collected and chemical analysis performed. The sampling program is both Valley-wide and site-specific. A complete sampling network has been established at the Niland test facility. Recently sampling has also begun in the three other major geothermal areas in the Imperial Valley: North Brawley, Heber, and East Mesa.

A significant achievement has been the discovery of an apparent "fingerprint" for water contaminated by geothermal brine. Work to-date at the Niland site has compared irrigation water, irrigation drain water, and Salton Sea water. These have somewhat similar characteristics, though the drain water and Salton Sea water are progressively enriched in sodium chloride relative to the irrigation source water. The analysis of geothermal brine shows a strikingly different compositional profile, being high in $\mathrm{K}$ relative to $\mathrm{Na}$, and very low in $\mathrm{SO}_{4}$ relative to surface waters. The brine also contains significant quantities of $\mathrm{Li}$, an element so unusual in ordinary water that it is used as a tracer in groundwater studies. The brines are also high in Mn and $\mathrm{Zn}$.

In the process of sampling, a sump was encountered containing water with very high electrical conductance. The sump (Sump 116) was located near the Sinclair $\#_{4}$ pond on Boyle Road. It was determined that the sump accumulates water from a tile system draining a nearby field. Analysis of the water indicated the pattern of elements to be anomalous relative to the normal surface water. A substantial amount of $\mathrm{Li}$ in the surface water strongly suggests an admixture of geothermal brine. In addition, the sample showed a low $\mathrm{Na} / \mathrm{K}$ ratio, high $\mathrm{Mn}$ and $\mathrm{Zn}$, and low $\mathrm{SO}_{4}$, a pattern fitting almost exactly that of geothermal brines. Evidence suggests that the old geothermal holding pond is leaking into the drainage system of sump 116. Although these data strongly suggest a definite relationship between geothermal brines and brine-contaminated surface water, it should be noted that this is a limited observation and awaits further verification.

\section{SUBSIDENCE AND SEISMICITY}

Any significant subsidence or seismic activity that might be induced by geothermal activity, primarily the production and injection of geothermal brines into the formation, would engender serious environmental concern in the Imperial Valley community. The detection of such earth movements in the presence of a high level of naturally occurring ground-surface subsidence and a degree of earthquake activity among the highest in the 
United States requires careful documentation of the present levels of activity and monitoring of any incremental surface movements.

A major accomplishment has been the installation of a high-resolution subsidence-detection network in the Salton Sea geothermal field area, centered on the SDGE/ERDA geothermal. test facility at Niland. This network will detect any local movement and has been tied in with the Valleywide network.

The Imperial Valley Environmental Project (IVEP) has contracted with the California Division of Oil and Gas to take part in a resurvey of the Imperial Valley Subsidence Detection Network. Previous data from this network have indicated a $13-\mathrm{cm}$ drop over a recent 2-year interval in the northern part of the Valley as compared to the mountains on either side of the Valley.

To obtain detailed seismic coverage in the Salton Sea area, the IVEP has contracted with the U.S. Geothermal Survey to install six seismometer stations. These units will be tied to the USGS regional network.

\section{ECOSYSTEM QUALITY}

Extensive baseline data are being collected on vegetation, soil, and animals. Site-specific collections have taken place on agricultural lands surrounding the Niland test facility.
A large number of soil and vegetation samples were collected by LLL and Environmental Protection Agency (EPA) teams. Currently, samples are being analyzed for trace metals.

In cooperation with the U.S. Fish and Wildife Service and the California Department of Fish and Game, vital organs from about 100 ducks and 20 geese were sampled at the Wildlife Refuges. A smaller number of 10 other species of birds were collected. These collections were from birds shot legally by hunters and from poached birds confiscated by law enforcement officers. Elemental analyses were performed on the various tissues.

\section{Samples in the Salton Sea area} were collected. The polychete worm Neanthes, commonly called the pileworm, is a sediment dweller and detritus converter and serves as food for every major fish in the Salton Sea: Other samples collected were the three major species of fish. All samples have been prepared for analysis of trace elements.

A network for routinely sampling agricultural products in the various Known Geothermal Resource Areas (KGRA) was established. The first samples of milk and vegetables have been collected. Trace analyses will be performed.

In the East Mesa KGRA, a team from UCLA has set up a program to sample 
desert vegetation, animals, and soil. All samples are being prepared for trace elemental analysis.

Air-pollution-effects studies have been conducted in the Imperial Valley. These involved setting up a series of experiments using exposure chambers over various agricultural crops. A mixture of gases $\left(15 \mathrm{CO}_{2}\right.$ : $1 \mathrm{H}_{2} \mathrm{~S}: 1 \mathrm{CH}_{4}: 2 \mathrm{~N}_{2}$ parts by volume added to air) prepared to simulate postulated releases from geothermal operations was used in the exposure chambers. Initial studies were conducted with lettuce plants.

\section{SOCIOECONOMIC EFFECTS}

A major effort has gone into establishing a background of data needed to do subsequent impact assessments related to socioeconomic issues raised by geothermal developments. Three baseline-characterization reports are in press and another report has been published. These reports deal with Imperial County economic characterization, Imperial County fiscal characterization, social characterization of Imperial County, and the 1972 flow of electrical energy in California and its relationship to selected county-1eve1-characteristic parameters.

Work on preliminary assessments is now underway: based upon selected development scenarios, system characterizations, and various models. The goal of this part of the program is to identify areas of primary concern for further study.

HEALTH EFFECTS

The Health Effects studies have not yet been implemented. Plans are currently being developed with the California Department of Health, and it is anticipated that the program will commence in FY 1977. Four major tasks are planned for the health effects studies:

- Publish a review of known sourceterm data and expected health effects with recommendations for needed basic research, if appropriate;

- Establish and maintain an exemplary program for reporting health statistics in Imperial County;

- Conduct studies of community response to odor pollution and perceived health effects; and

- Review occupational health programs at geothermal facilities, and examine if special health monitoring tests would be desirable.

INTEGRATED ASSESSMENT

A comprehensive report is in press; it covers the physical and - biological environments of the 
Imperial Valley. This report presents relevant background information on the Valley that will be required in making impact assessments of geothermal developments.

Underway are a set of geothermal energy scenarios that include powerdevelopment schedules, technology characterizations, and considerations of power-plant-siting criteria. Also a Gaussian air-pollution model has been modified for use in preliminary air-quality assessments. A cropgrowth model has been developed to evaluate impacts of gases released from geothermal operations on various agricultural crops. Work has also progressed on the legal analysis of geothermal legislation and the legal aspects of water-supply utilization.

Data acquired by the measurement groups (i.e., air quality, water. quality, ecosystem quality, etc.) have been entered into a data base for future retrieval and analyses. An important aspect of the Integrated Assessment element is to transfer information to government agencies, legislative bodies, and planning groups. Information on air quality is now being routinely transferred to the Air Resources Board of California. These data will be used by developers of geothermal resources in the Imperial Valley.

REMOTE SENSING

The IVEP is currently receiving remote sensing support from $E G \& G$, Las Vegas, Nevada. This effort has been directed for the most part at the Salton Sea, Heber, Brawley, and East Mesa KGRAs. However, largeformat photography of the entire Salton Trough has been completed. Thermal and multispectral imaging has been done for several selected sites in the Salton Sea KGRA. This information will serve as background data for thermal distributions and crop conditions.

\section{RESEARCH SUPPORT CONTRACTS}

Contracts to government agencies and universities totaling over $\$ 450,000$ were let in FY 1976. Although the contracts are supported by FY 1976 funds, most of the work will actually be done in FY 1977. The contracts are distributed by IVEP elements as follows:

$\begin{array}{lr}\text { - Air Quality } & 4 \\ \text { - Subsidence/Seismicity } & 3 \\ \text { - Socioeconomic Effects } & 3 \\ \text { - Ecosystem Quality } & \frac{15}{25} \\ \text { Total } & \end{array}$


Tl= 



\section{Introduction}

Paul L. Phelps

A geothermal loop experimental facility in the Imperial Valley, jointly sponsored by the San Diego Gas and Electric Company (SDGE) and the Energy Research and Development Administration (ERDA) resulted in ERDA sponsoring a program to establish an environmental data baseline for the Imperial Valley and to assess the potential environmental impact of future geothermal installations in the Valley. The Lawrence Livermore Laboratory (LLL) at the request of the Assistant Administrator for Environment and Safety of ERDA was appointed the Lead Laboratory to set up and manage an environmental baseline program. Subsequently, the Imperia1 Valley Environmental Project (IVEP) was established.

This progress report represents a summary of the goals and accomplishments of the IVEP. This report covers approximately the first year of field work in the Valley and should prove useful to developers and planners engaged in activities related to the development of geothermal resources in the Imperial Valley and elsewhere. While the progress report does contain a good deal of technical detail, it is not intended as a substitute for complete in-depth reports that are forthcoming from the various IVEP elements.

Efforts in the first year centered on development of a comprehensive plan and its initial implementation. This resulted in the following accomplishments:

- Completed detailed plans for all IVEP elements, except for Health Effects;

- Identified IVEP participants and established functional relationships;

- Negotiated over 30 contracts with various government agencies, universities, and private concerns;

- Specified and purchased complex -instrumentation for field systems;

- Established protocols for conducting environmental baseline measurements and sample collections;

- Began installation of field stations for long-term environmental sampling;

- Began conducting source-term measurements, field-baseline measurements, and sample collections;

- Planned and initiated high priority environmental effects studies;

- Wrote a comprehensive report to describe the existing physical and biological environment of Imperial Valley; 
- Developed preliminary geothermal scenarios for Imperial Valley; and

- Established an Advisory Panel to review the IVEP plans and results. The IVEP is a long-term effort to acquire complete understanding of the environmental quality in the Imperial Valley of California prior to any major geothermal developments. The purpose of this project is to ensure that the development of geothermal resources proceeds on an environmentally sound basis. Consequently, the Imperial Valley Environmental Project is committed to an intensive and comprehensive study for the establishment of an environmental baseline for the Imperial Valley as well as an understanding of the possible effects upon the environment that may be associated with the development of geothermal resources.

The IVEP is an integrated project bringing together under a single management (see Fig. 1) a11 areas of expertise needed to cover the significant issues and concerns. The areas of expertise are represented by the following sections:

- Air Quality,

- Water Quality,

- Ecosystem Quality (soil, plants, anima1s, etc.),

- Subsidence and Seismicity,

- Health Effects,

- Socioeconomics, and

- Integrated Assessment.
A strong thrust of the project is to integrate the output of the various studies into a single overall assessment. This includes not only the data obtained from the Lawrence Livermore Laboratory studies but input from all other identifiable programs as well. To this end, the Imperial Valley Environmental Project has developed a data base from information available through a number of studies relating to the long-term environmental assessment of the Imperial Valley. The Lawrence Livermore Laboratory is working closely with a number of universities and various federal, state, and county agencies and other groups to obtain the needed information. These efforts are in part funded by the Imperial Valley Environmental Project. Also, a great deal of cooperation with various other public groups has been achieved, and their programs in some cases have been reoriented to assist on problems specific to the development of geothermal resources in Imperial Valley. A summary of the participants is given in Table 1 .

Several measures are being taken to assure quality of performance and accuracy of data from the IVEP. Among these are:

- Establishment of an Advisory Pane1 made up of members from many significant sectors concerned with geothermal development. The 
Project Organization

Imperial Valley Environmental Project

LLL Lead Laboratory

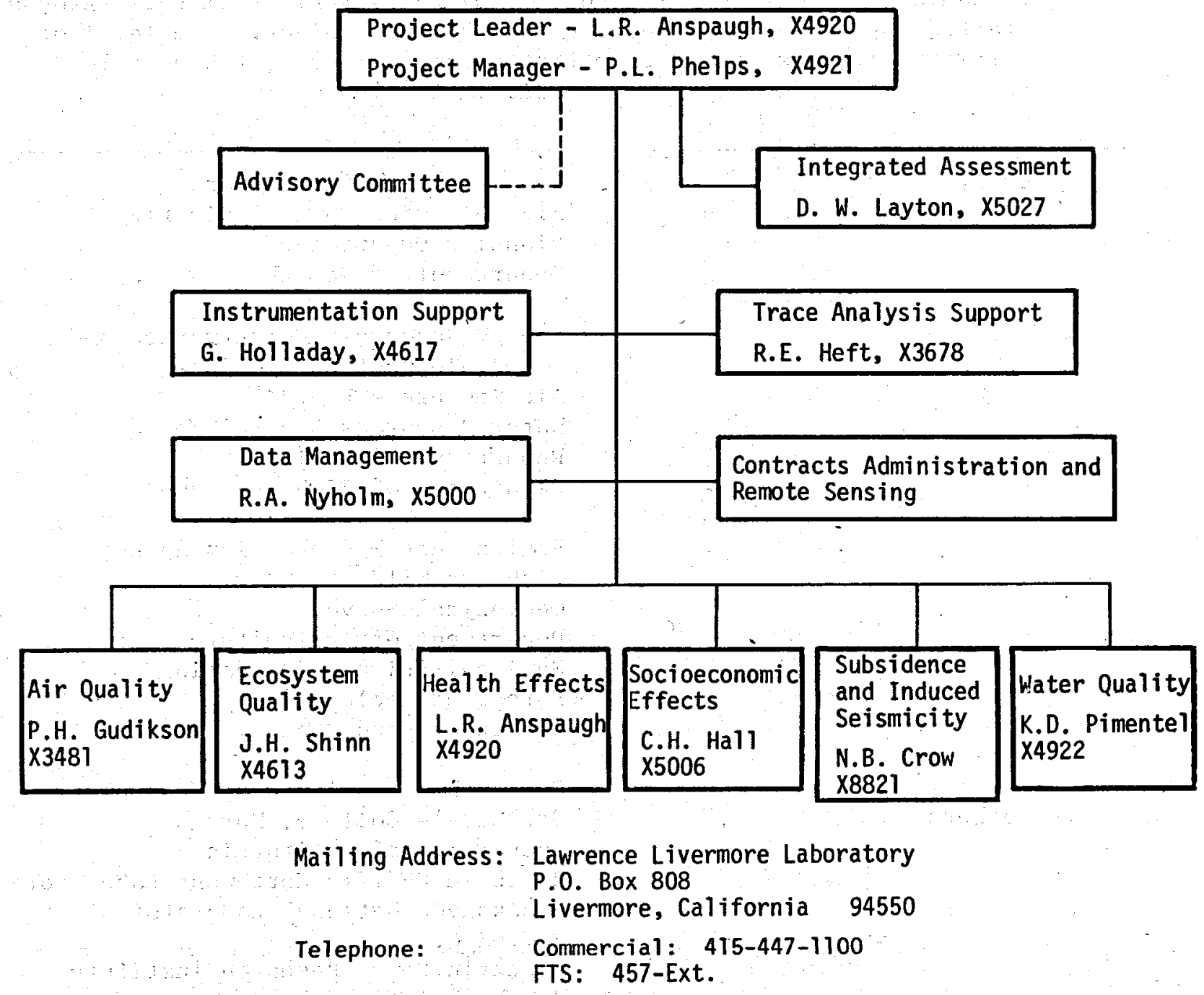

Fig. 1. Project organization of the Imperial Valley Environmental Project.

membership is 1isted under "Advisory Panel" of this report.

- Interchanging of environmental samples and standards with other laboratories and comparing results obtained by various analytical methods.
- Use of approved 1aboratories for elemental analysis, i.e., water samples are done by state certified 1aboratories.

- Calibration of instruments and standards by the California Air and Industrial Hygiene Laboratory. 
Table 1. IVEP Participants. Participants in the IVEP have been drawn from various county, state, and federal government agencies, universities and ERDA contract laboratories, geothermal developers, and utility companies. Involvement in the IVEP by individuals from these groups started in the early planning phases of the project. The level of participation has ranged from that of an advisor to taking a lead part in field and laboratory studies.

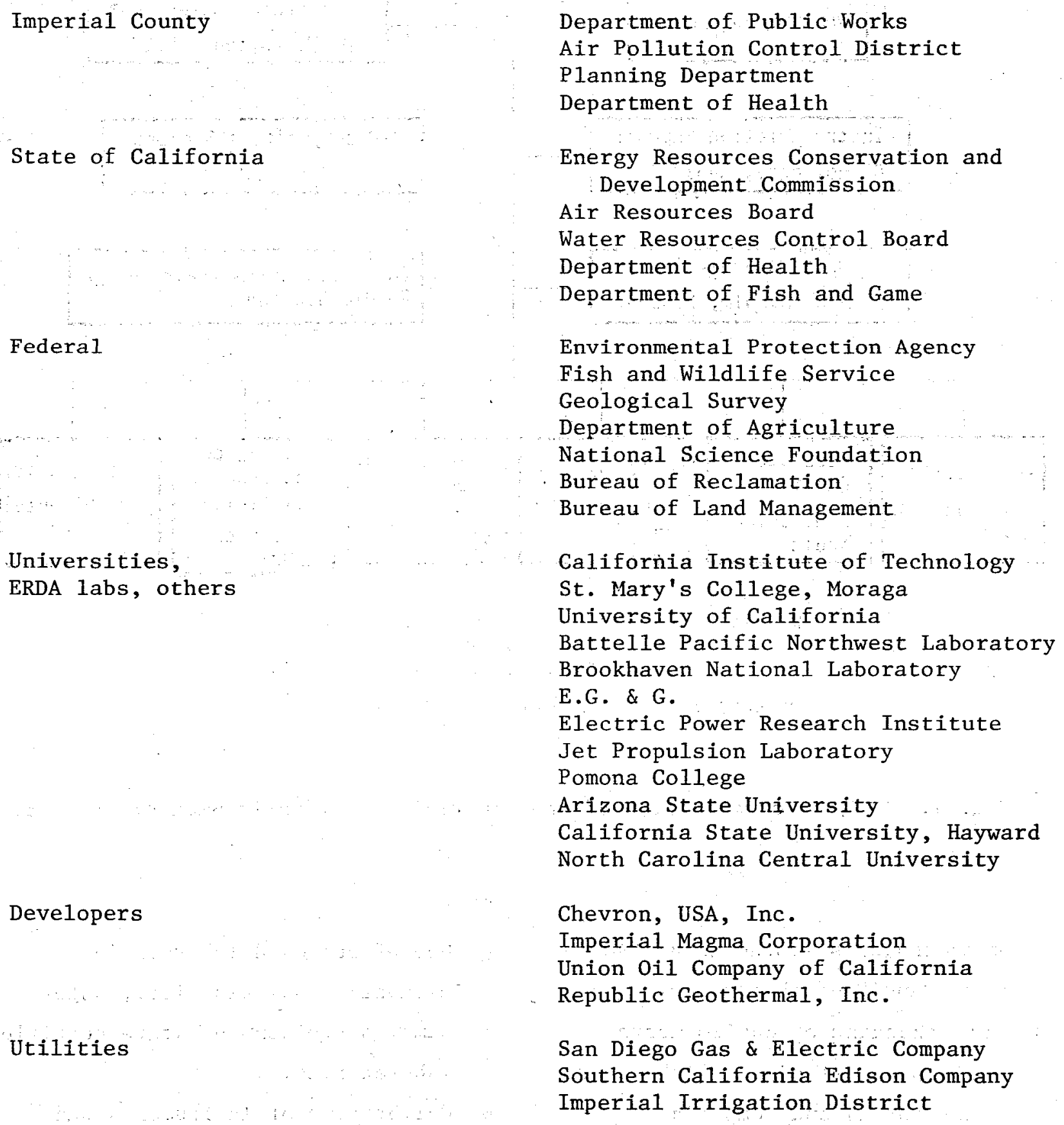

Department of Public Works

Planning Department

Department of Health

nergy Resources Conservation and

ir Resources Board

ater Resources Control Board

Department of Health

Environmental Protection Agency

Fish and Wildlife Service

Geological Survey

Department of Agriculture

National Science Foundation

Bureau of Reclamation

California Institute of Technology

. Mary's College, Moraga

Brookhaven National Laboratory

Jet Propulsion Laboratory

Pomona College

Arizona State University

California State University, Hayward North Carolina Central University

Imperial Magma Corporation

Union Oil Company of California

San Diego Gas \& Electric Company

Imperial Irrigation District 
- Calibration checks of field air quality systems by the Environmental Protection Agency.

- Periodic peer review by ERDA staff and technical consultants.

A few changes have taken place in the IVEP management structure. The Socioeconomics Effects element was previously under the direction of K. F. Haven, who since has left LLL. C. H. Hall is now responsible for this element. T. D. Palmer has also resigned his position at LLL. Currently his vacancy in the Contracts Administration and Remote Sensing element has not been filled. D. W. Layton is now in charge of the
Integrated Assessment element, replacing R. L. Ritschard, former leader for the Integrated Assessment element, and L. R. Anspaugh, former acting element leader.

Financial support for the IVEP is from the Assistant Administrator for Environment and Safety of the Energy Research and Development Administration. A major focal point for the IVEP is the Division of Technology Overview, Office of Environment and Safety. Field liaison to ERDA is maintained through the ERDA San Francisco Operations office. These relationships are shown in Fig. 2 . 


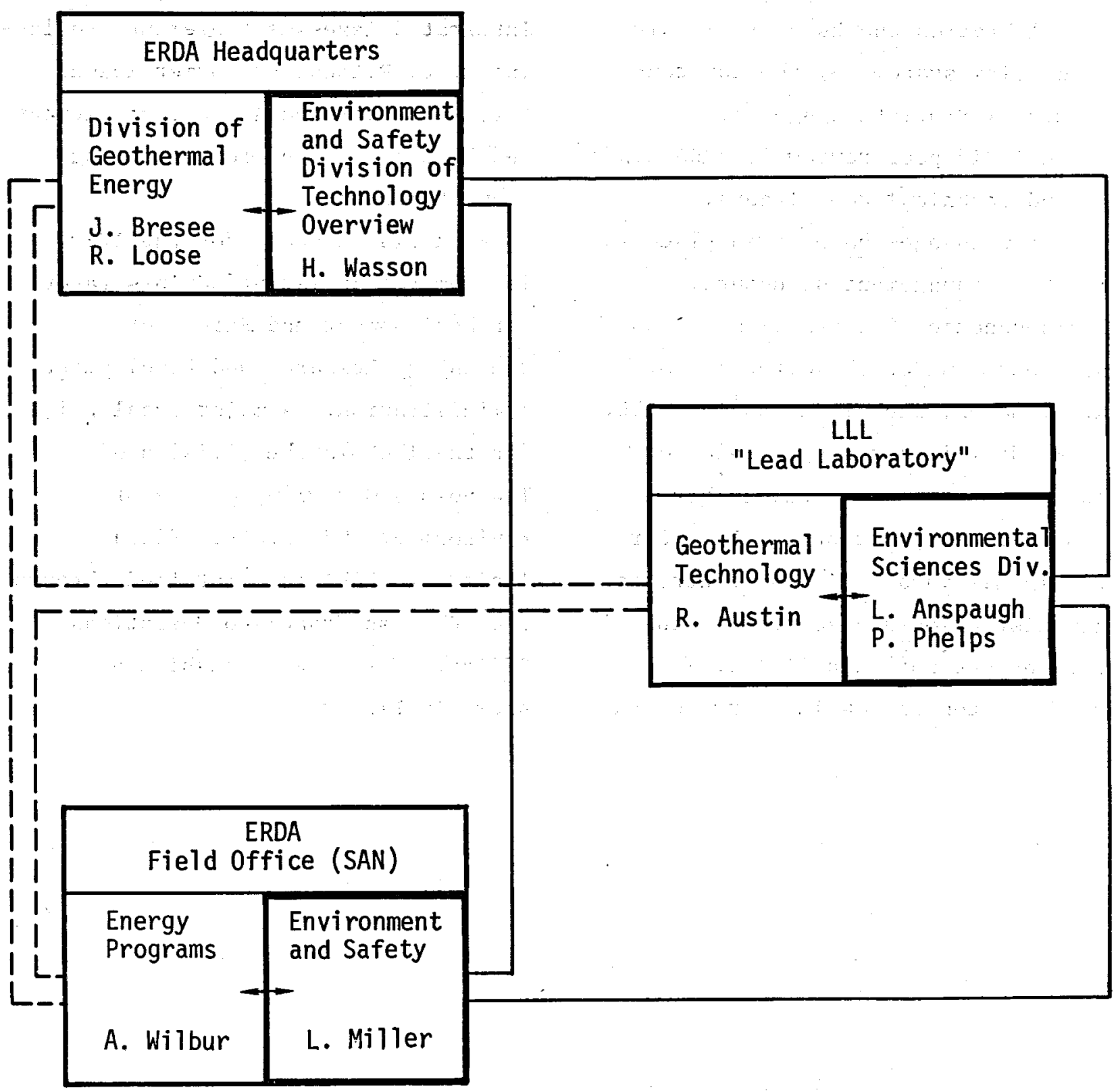

Fig. 2. Relationship of the Imperial Valley Environmental Project (IVEP) to the U.S. Energy Research and Development Administration. The IVEP is under the auspices of the Assistant Administrator for Environment and Safety of ERDA. Close coordination exists between the Geothermal Technology and Environmental groups. Names indicated are principal contacts. 
Imperial Valley Environmental Project (IVEP) Elements 



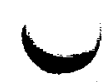

IMPERIAL VALLEY ENVIRONMENTAL PROJECT

Air Quality 
AIR QUALITY

Pau1 H. Gudiksen

Introduction

One of the potentially important impacts of large-scale development of geothermal resources within the Imperial Valley is the degradation of air quality. Nearly all geothermal development schemes will release noncondensable gases to the atmosphere. The principal constituent of the noncondensable fraction is $\mathrm{CO}_{2}$, but lesser amounts of $\mathrm{H}_{2} \mathrm{~S}, \mathrm{H}_{2}, \mathrm{CH}_{4}, \mathrm{NH}_{3}$, and $\mathrm{N}_{2}$ are generally present as well. To assess this impact, the objectives of the Air Quality Program are to:

- Measure the current levels of selected air pollutants at various locations within the Imperial Valley;

- Characterize the atmospheric transport properties on a Valley-wide basis by measuring specific meteorological parameters at several

locations;

- Characterize the concentrations of specific pollutants in the vicinity of specialized sources connected with geothermal operations and agricultural activities;

- Evaluate the rate of emissions of selected pollutants from geothermal operations;

- Measure the transport of pollutants across the northern and southern boundaries of the Valley; and
- Utilize the above data in our atmospheric transport models to predict the annual average change in air quality throughout the entire valley resulting from the operation of postulated geothermal power plants situated anywhere within the Valley.

To accomplish these objectives we have established a multidisciplinary program that requires the combined efforts of many investigators from several laboratories. The first three objectives are being addressed by the installation of six fixedlocation air-quality and meteorological-monitoring stations in the Imperial Valley and the utilization of a mobile air-quality laboratory for site-specific measurements. The monitoring systems are being assembled and fielded by LLL personnel with support from the State of California Air and Industrial Hygiene Laboratory and Air Resources Board. The Imperial Valley Air Pollution Control District will supply additional manpower to assist in the normal operation of the stations. Particulate sampling and analyses will be performed by investigators from the University of California at Davis, Rockwell International, Brookhaven National Laboratory, and Lawrence Livermore Laboratory (LLL). The U.S. Environmental Protection 
Agency (EPA) (Las Vegas) will be responsible for the conduct of the quality assurance program for the ambient-air gas analyses. The EPA will also supplement our program by making additional air-quality measurements in specific areas. In addition, airborne measurements made by EG\&G, Inc. will provide vertical profiles of pollutant concentrations. The evaluation of the emissions of pollutants also draws upon the talents of investigators from several laboratories. Measurements of specific chemical species in the noncondensable gases emitted by geothermal operations will be performed by personnel from the Battelle Pacific Northwest Laboratories, LFE Environmental Analysis Laboratories, U.S. EPA (Las Vegas), and LLL. The final objective will be to utilize these data as input to atmospheric transport models for the prediction of the impact of geothermal operations on the Valley's air quality. This wil1 be performed at LLL using advanced three-dimensional transport models.

\section{Fixed Air-Quality and Meteorological}

\section{Monitoring Stations}

We are currently in the process of installing the six stations within the Valley. Each station will provide measurements of wind speed, wind direction, temperature, relative humidity, and the concentration of
$\mathrm{H}_{2} \mathrm{~S}, \mathrm{SO}_{2}, \mathrm{O}_{3}, \mathrm{CO}_{2}$, and particles. In addition, three of the stations will be equipped with the capability to measure the concentrations of $\mathrm{NO}, \mathrm{NO}_{2}$, and $\mathrm{NO}_{\mathrm{x}}$.

The sites where the six air-quality stations will be situated are shown in Fig. 1. The selection of these sites was based on the most likely geothermal source points, the expected current ambient-air-pollutant levels, the distribution of population centers, and meteorological considerations. Two sites (Nos. 1 and 5) were chosen near the south end of the Salton Sea to define the flow entering into or exiting out of the north end of the Valley. Site No. 1 is situated about $1 \mathrm{~km}$ northwest of the San Diego Gas and Electric Company's (SDG\&E) Geothermal Loop Experimental Facility near Niland. Similarly two sites are located near the southern border at the Heber and East Mesa KGRAs (Known Geothermal Resource Area) to evaluate the flow of pollutants across the southern boundary. Another site is situated slightly north of Brawley on a Union 011 Company lease where future geotherma 1 development is expected. The latter represents a recent change in location that was requested by the Union 0il Company. The remaining site was selected within the city of Imperial to provide coverage for the central section of the Valley. 


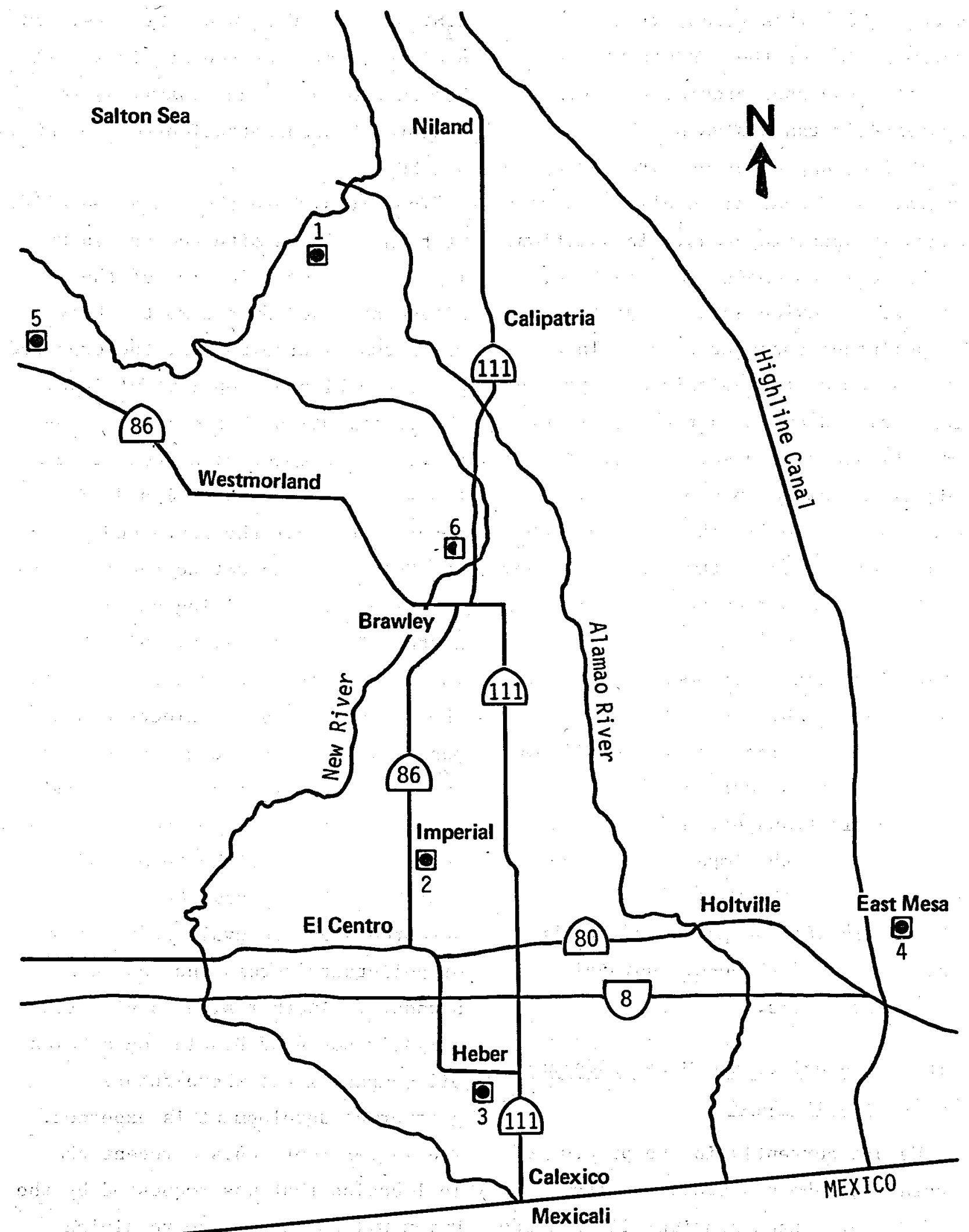

Fig. 1. Map of Imperial Valley showing the location of the air-quality stations. 
The air-quality station at Site No. 1 has been operating since June 1976. It has provided data on the ambient-air concentrations of $\mathrm{H}_{2} \mathrm{~S}$, $\mathrm{SO}_{2}$, and $\mathrm{O}_{3}$ as well as wind speed, wind direction, temperature, and relative humidity. An additional four stations have been shipped to the Imperial Valley. Two of these have been installed at the East Mesa and Heber sites (Nos. 4 and 3 , respectively). At the Brawley Site (No. 6) we are waiting for the installation of commercial power by the Union Oil Company so that we can instal1 our monitoring system. We are also setting up Station No. 5 at the southwest corner of the Salton Sea, but unfortunately that unit was severely damaged during commercial shipping from LLL to the Imperial Valley and requires major repair work. The remaining Station No. 2 is waiting at LLL for delivery of additional parts.

We expect to have Stations 1, 3, and 4 operating during November 1976 and the remaining stations on line by the end of CY 1976. This does represent a departure from our earlier estimates because of unexpected delays in parts and equipment deliveries as wel1 as the severe damage incurred by Station No. 5 during transit. In addition, the installation of commercial power at various sites has taken longer than expected because of increased workloads for the linemen caused by the occurrence of unusual rain storms. This inclement weather has also slowed our field activities.

Each station consists of an airconditioned trailer, housing the airquality instruments and the dataprocessing and recording systems. Five of the stations are also equipped with $10-m$ instrumented meteorological towers. The Heber Site No. 3 contains a 60-m tower, instrumented at 2 levels and erected by the San Diego Gas and Electric Company (SDG\&E) under Electric Power Research Institute (EPRI) funding. Each station has the capability of measuring $\mathrm{O}_{3}$, $\mathrm{SO}_{2}, \mathrm{H}_{2} \mathrm{~S}$, and $\mathrm{CO}_{2}$, while three stations will a1so be capable of measuring $\mathrm{NO}, \mathrm{NO}_{2}$, and $\mathrm{NO}_{x} \cdot \mathrm{AHi}-\mathrm{Vol}$ sampler is mounted on the roof of each trailer for mass-loading measurements. In addition, a three-stage impactor is included in each station to collect samples for elemental analysis of particles. Meteorological measurements at each station include wind velocity, temperature, and relative humidity. Solar radiation and visibility measurements will be made at one station. An acoustic sounder will also be employed for inversionheight determinations.

A photograph of a typical station with a trailer and a 10-m tower in 
the background is shown in Fig. 2 . Table 1 provides a listing of the airquality and meteorological sensors utilized in the program. Figure 3 is a schematic diagram of a typical station. Air is drawn in at a height of $5 \mathrm{~m}$ through a glass and Tefion sample train leading to the airquality instruments. The outputs from these instruments are fed into a digital cassette-tape-recording system that was designed and built

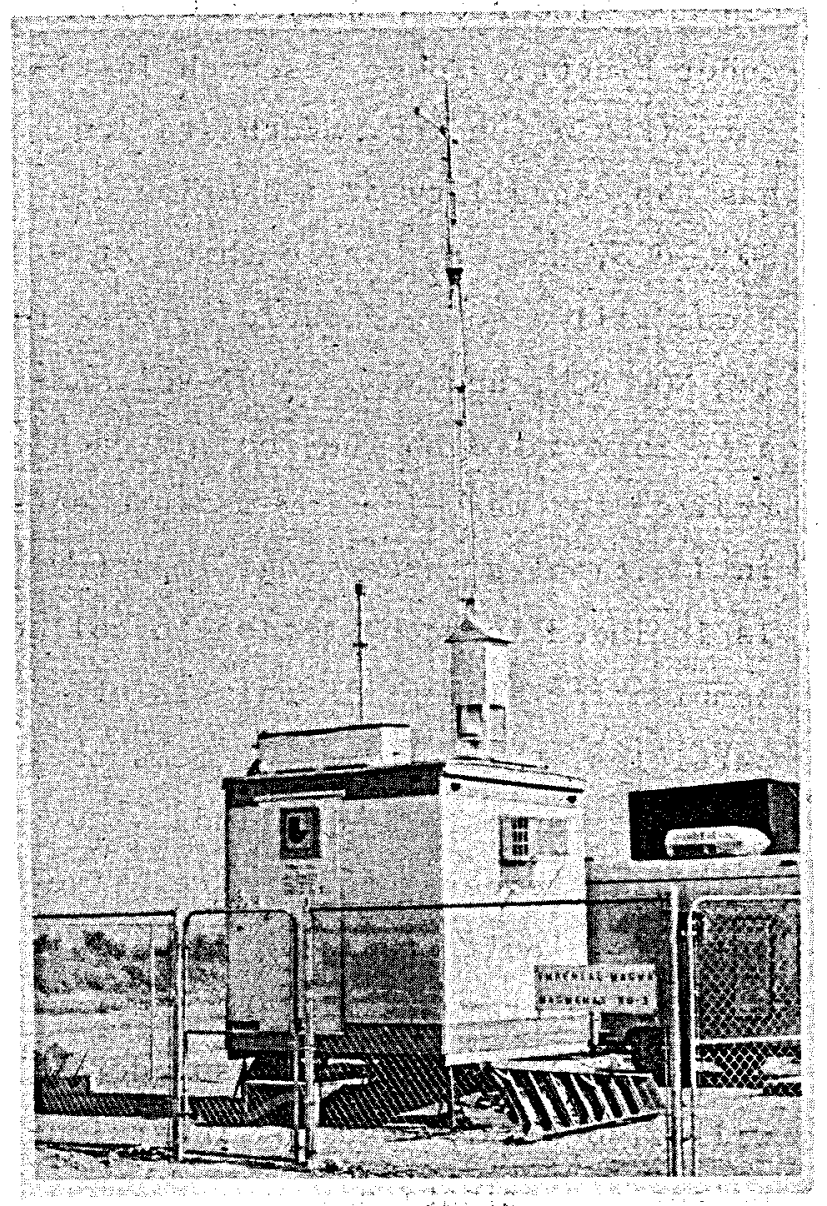

Fig. 2. Exterior view of an air-quality station showing the trailer and the 10-m meteorological tower. at LLL. This unit contains 32 channels and features dual recorders. When recording the data in all channels at 15-min intervals, the system can accumulate data for 1 month without changing cassettes. This datalogging system also includes signal conditioning for the meteorological sensors. All signals are normally averaged over 15-min periods. Peak values of all air-quality measurements are also recorded. Data in selected channels are recorded by two 6-channel strip-chart recorders. This serves as a back-up to the tape systems and provides a means for evaluating instrument performance in the field. The instruments are mounted on a dual rack as shown in Fig. 4.

The tape cassettes are being collected on a weekly basis for transport to LLL where the data can be extracted by a minicomputer to produce an IBM-compatible nine-track tape. This tape can then be used as a transfer medium to the LLL computer system for data analysis. The hardware and software for this transfer mechanism are currently available. The software development for the data analysis is presently underway.

\section{Mobile Air-Quality Laboratory}

To supplement the fixed stations for specialized studies, a mobile air-quality field laboratory is under 
Table 1. Air-quality and meteorological instrumentation used in a typical air-quality station.

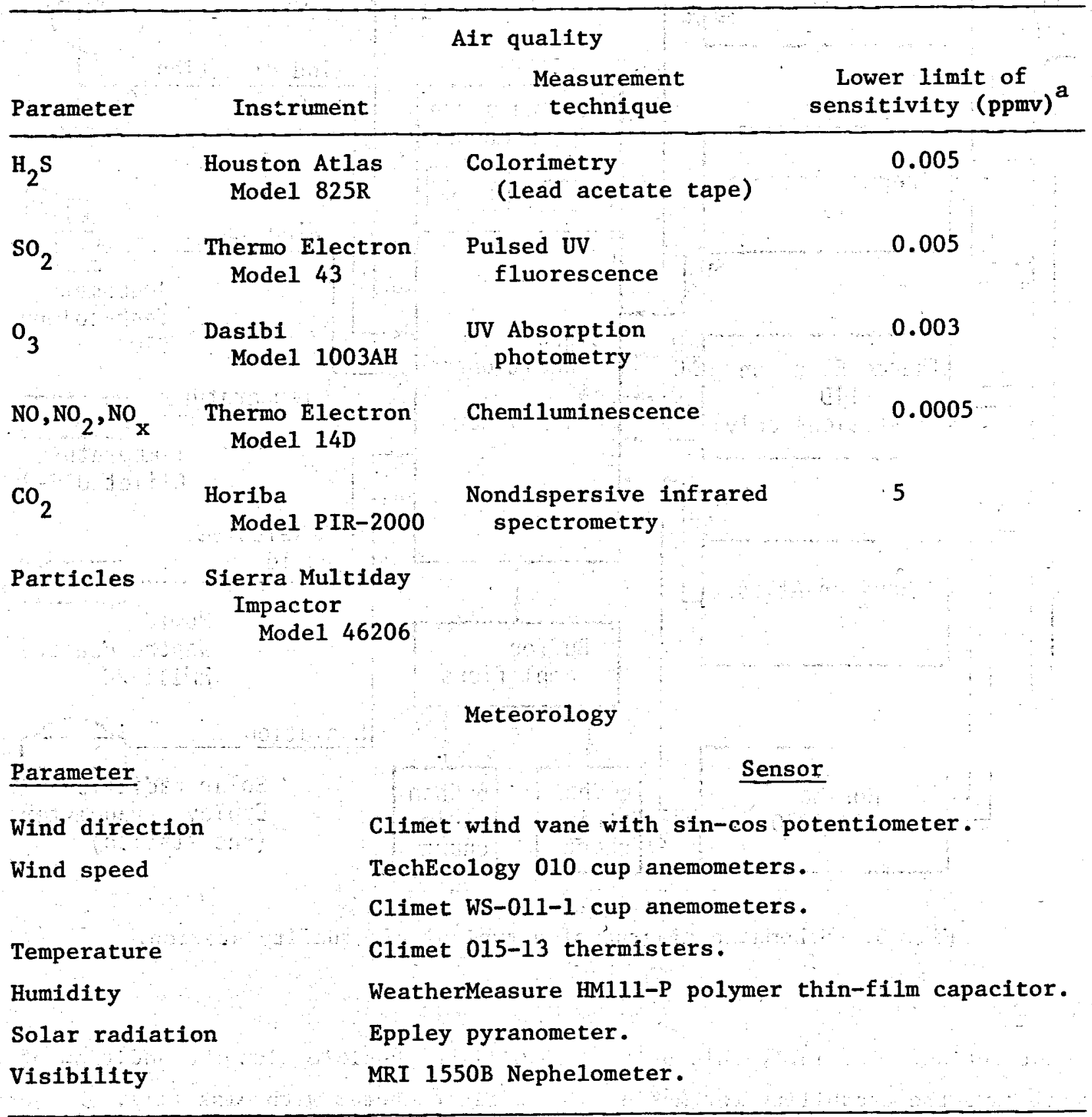

a Parts per million by volume. 


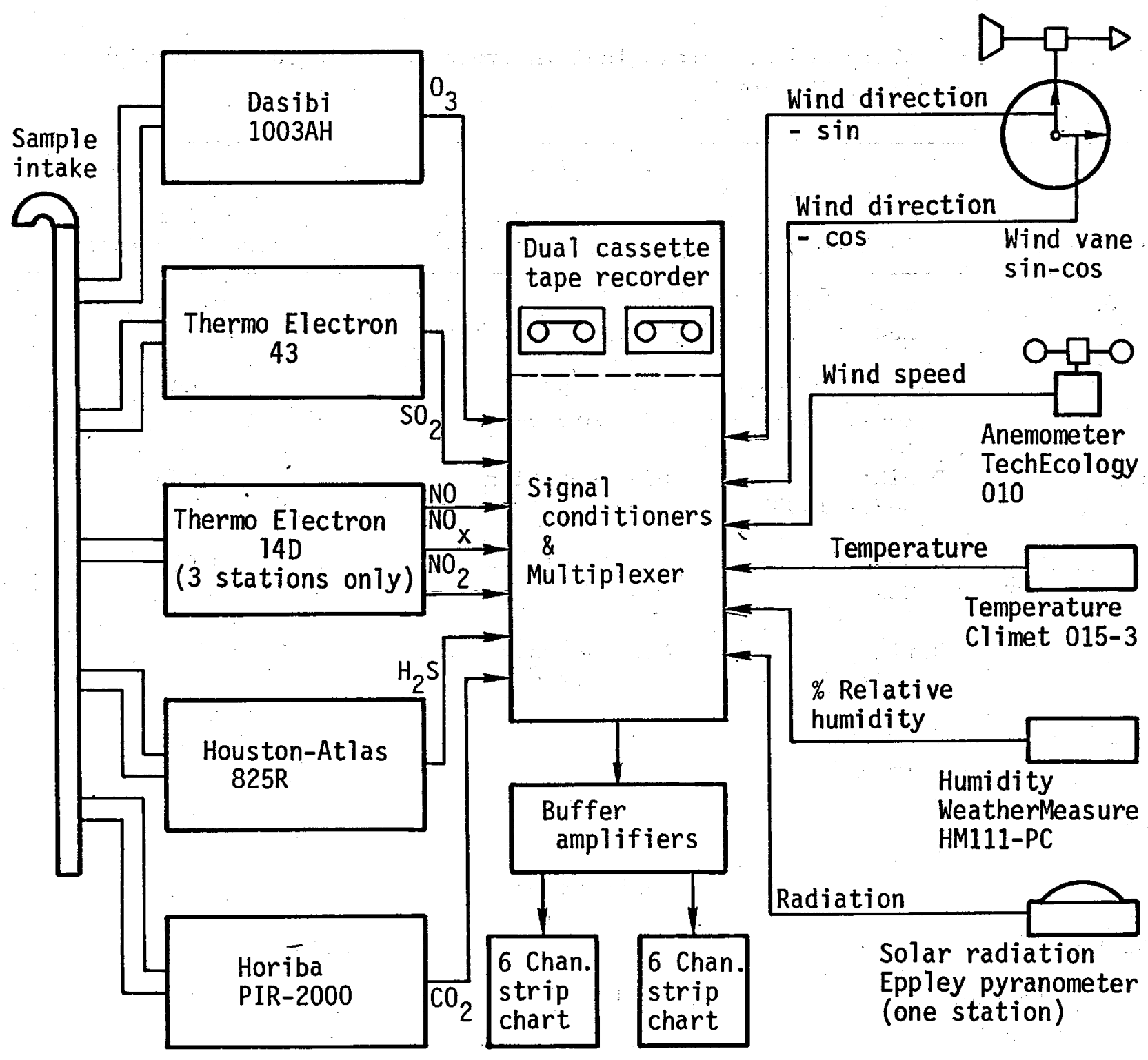

Fig. 3. Schematic diagram of a typical air-quality station.

construction. Initially this unit will have the capability for making the air-quality and meteorological measurements shown in Table 2. It is anticipated that this capability will be expanded to include an analytical chemistry laboratory for performing a variety of source measurements. Real-time processing of data will be possible with the addition of a minicomputer with disk file, magnetic-tape storage, graphics, printer, and plotter.

We selected the GMC Transmod mobile-home chassis as the base for the mobile laboratory because of its excellent road handling capabilities and a suspension system that 


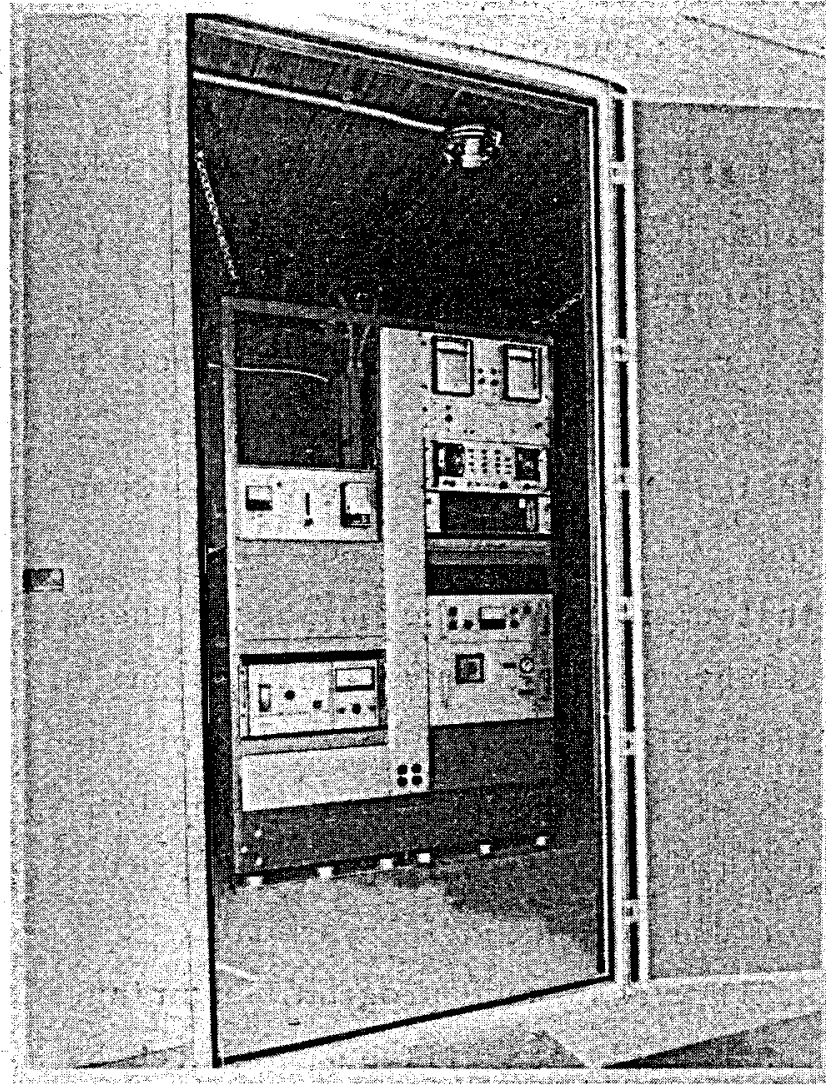

Fig. 4. An interior view of an airquality station.

\section{Gas Calibration Systems}

To calibrate the air-quality instruments in the 1aboratory and in the fleld, it was necessary to construct two gas-calibration systems that will deliver gas streams containing known concentrations of test gases. These systems operate on the dilution principle: Cylinders containing gases in relatively high concentrations ( $I$ to 50 ppmv) are diluted very accurately with clean air, referred to as zero air. One of

Table 2. Mobile air-quality laboratory capabilities.

\begin{tabular}{cc} 
Air quality & \multicolumn{1}{c}{ Meteorology } \\
\hline $\mathrm{H}_{2} \mathrm{~S}$ & Wind speed \\
$\mathrm{SO}_{2}$ & Wind direction \\
Total sulfur & $\begin{array}{l}\text { Temperature } \\
\text { Relative humidity }\end{array}$ \\
$\mathrm{O}_{3}$ & Solar radiation \\
$\mathrm{NO}$ & \\
$\mathrm{NO}_{2}$ & \\
$\mathrm{NO}_{\mathrm{X}}$ & \\
$\mathrm{CO}$ & \\
$\mathrm{CO}_{2}$ & \\
$\mathrm{CH}_{4}$ \\
Total \\
hydrocarbons \\
$\mathrm{NH}_{3}$ \\
Particles \\
\hline
\end{tabular}


these calibrators is a flexible, wide-range laboratory system for initial calibration of newly acquired instruments and recalibration of instruments returned from the field. A schematic diagram of the system is shown in Fig. 5. The zero-air system is a major component of the calibrator. Room air is passed through a series of filters, converters, and reagent beds to remove trace gases in the air stream to produce the zero air. The concentrated span gas, whose concentration is accurately known, is blended with zero air in a Teflon mixing chamber. The ratio of span gas to zero air can be accurately regulated by a combination of pressure and flow regulators and calibrated rotameters. Thus, it is possible to deliver a stream of air whose concentration of pollutant gas is accurately known and that can be varied to calibrate all ranges of the instruments. A photograph of this system is shown in Fig. 6 and is operable at this time.

For routine calibration of instruments within the air-quality stations, a field calibrator has been built. It is similar to the laboratory calibrator with appropriate modification for field adaptation. It is mounted on the bed of a pick-up truck, enabling us to deliver the calibration gas directly to the sample intake on the roof of the air-quality station.
The accuracy of these calibrators is being independently verified by the State of California Air and Industrial Hygiene Laboratory, Berkeley, California, under contract to this program. The cost of the contract is $\$ 25,000$. The scope of the work includes the calibration of the spangas cylinders, the air-quality instruments, and the output of these calibrators. It a1so includes an audit of the entire operation of the six stations. In addition, the U.S. EPA (Las Vegas) will be responsible for the conduct of a systematic quality-assurance program, ensuring that valid data will be generated by the air-quality sensors. This service will be provided at no cost to this program.

These calibrators do not include an ozone-generation capability. The State of California Air Resources Board is currently calibrating our ozone analyzers on a cooperative basis.

\section{Instrument Development}

Since no commercial instrument is currently available that is capable of low-level ammonia measurements, L. Hrubesh at -LLL is developing an ammonia monitor for our studies. It is based on the principle of the absorption of microwaves by rotating $\mathrm{NH}_{3}$ molecules in their vapor phase. The absorption process is quantized, 

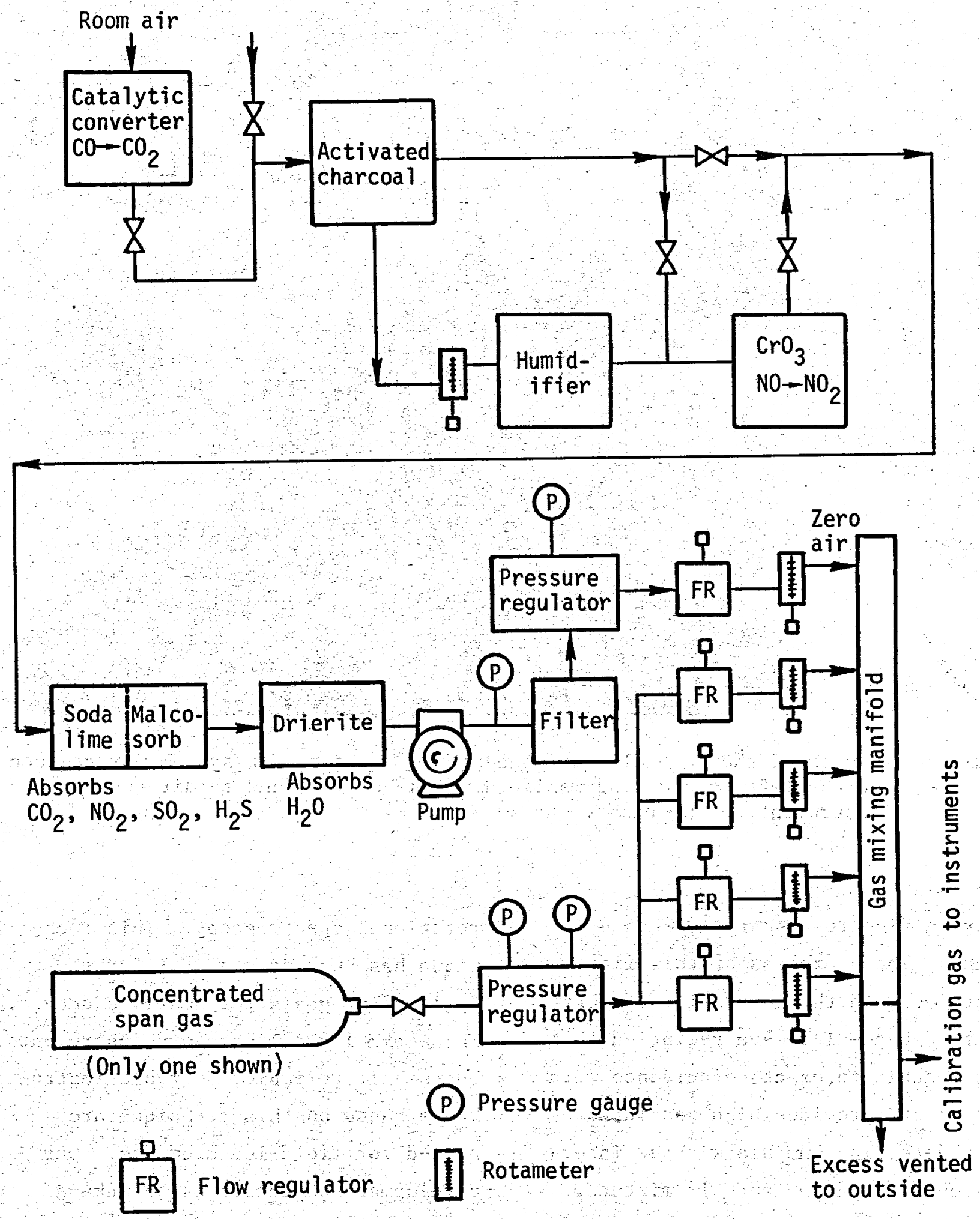

Fig. 5. A schematic diagram of the gas-calibration system for 1aboratory use. 


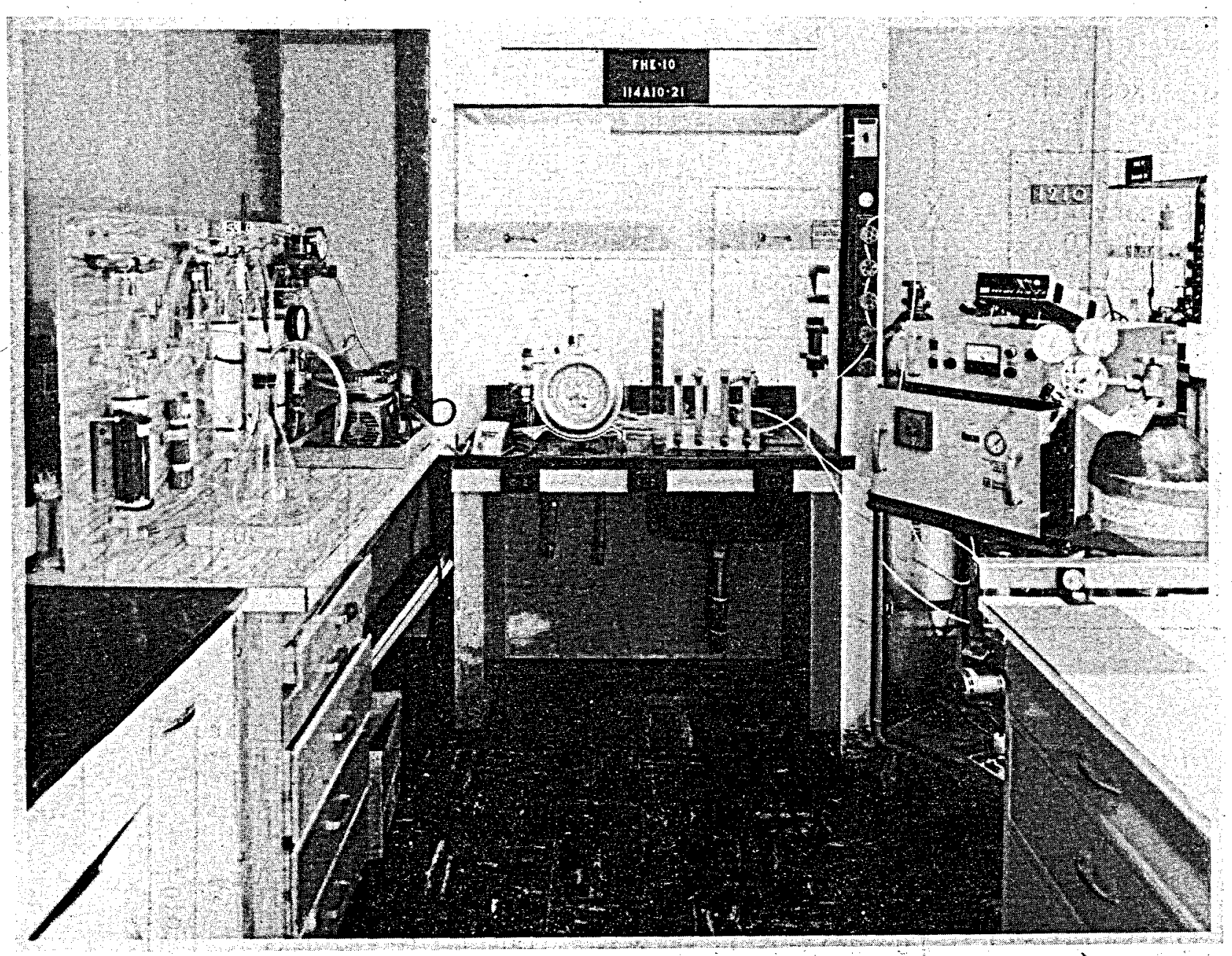

Fig. 6. A view of the gas-calibration system. The zero-air system may be seen on the left, the mixing manifold in the center, and an air-quality instrument on the right.

giving rise to a sharp resonance line. The sharpness of this line, coupled with the generation of very narrow-band-microwave radiation that is tunable to exact coincidence with the peak, provides high resolution for detecting ammonia without interference in an ambient-air mixture.

The analytical capability of this technique, not only for ammonia but for many other gases as we11, has been well established as microwave rotational spectroscopy. This technique has been used at LLL for the analysis of gases for nearly a decade. These are large laboratory instruments, but smal1, reliable, portable instruments based on this technique are needed for field measurements. Our development objective is to make a field-usable instrument specifically for ammonia gas. The microwave sources are solid-state oscillators that require little power and are 
quite amenable to portable instrumentation, but they are too unstable with regard to frequency to stay on the peak of the ammonia absorption for the long periods required as a monitor. To solve this problem we have developed an automatic stabilization scheme that locks the microwave oscillator to the line peak, ensuring long-term accuracy for the ammonia measurement. The concept has been fully proved in a breadboard mode1.

In another breadboard mode1, as little as 50 ppbramonia in air has been detected by the microwaveabsorption method. Additional sensitivity, extending the sensitivity to below 1 ppbv can be obtained by concentrating the sample with a material that can trap ammonia from an ambient flow, then release it upon heating for detection by the monitor. A device that automatically controls the trapping procedure and records the ammonia signal has already been developed and is under test. We expect to have a fully operational unit by February 1977.

\section{Ambient-Air Measurements}

Station No. 1 near the SDG\&E facility has provided us with data on the ambient-air concentrations of $\mathrm{H}_{2} \mathrm{~S}, \mathrm{SO}_{2}$, and $\mathrm{O}_{3}$ as well as wind speed, wind direction, temperature, and relative humidity since June 1976.
The concentrations of these species are extremely low within the northern end of the Valley. The concentrations of $\mathrm{H}_{2} \mathrm{~S}$ generally average about 0.005 $\pm 100 \%$ ppmv, the lower limit of sensitivity of our instruments. Periodic excursions up to 0.02 to $0.03 \mathrm{ppmv}$ have been measured. The causes of these excursions are not clear at this time, but may possibly be a result of nearby agricultural fertilizer applications. The $\mathrm{SO}_{2}$ concentrations are also low, averaging about $0.005 \pm$ $100 \%$ ppmv, the lower sensitivity of the instrument. Ozone concentrations, on the other hand, vary between 0.01 to 0.05 ppmv with maximum of 0.1 ppmv occurring occasionally. These values agree well with those measured by the State of California Alr Resources Board Mobile Monitoring Unit at an adjacent site from January through March 1976. A summary of their data is given in Table 3 . In addition, personnel from the U.S. Environmental Protection Agency (Las Vegas) have measured $\mathrm{H}_{2} \mathrm{~S}$ and $\mathrm{SO}_{2}$ concentrations from July through September 1976 at the U.S. Bureau of Reclamation facilIty at East Mesa, at the town of Niland, and at a site approximately $2 \mathrm{~km}$ south of the SDG\&E facility. All of their measurements provided values less than the detection limit of the flame-photometric detector (0.005 ppmv) with the exception of a few values that reached a maximum 
Table 3. Summary of the air-monitoring data from the State of California Air Resources Board Mobile Unit.

\begin{tabular}{|c|c|c|c|c|c|c|c|c|c|}
\hline \multirow[b]{2}{*}{ Species } & \multirow[b]{2}{*}{ Units } & \multirow[b]{2}{*}{ Monitoring period } & \multirow{2}{*}{$\begin{array}{l}\text { No. of } \\
\text { measure- } \\
\text { ments }\end{array}$} & \multicolumn{2}{|c|}{ Hourly concentrations } & \multirow{2}{*}{$\begin{array}{l}\text { Average hourly } \\
\text { concentration }\end{array}$} & \multirow{2}{*}{$\begin{array}{l}\text { Average maxi- } \\
\text { mum hourly } \\
\text { concentration }\end{array}$} & \multirow{2}{*}{$\begin{array}{r}\text { State of } \\
\text { and/or } \\
\text { sta }\end{array}$} & \multirow{2}{*}{$\begin{array}{l}\text { California } \\
\text { federal } \\
\text { adard }\end{array}$} \\
\hline & & & & Low & $\mathrm{High}$ & & & & \\
\hline $\mathrm{o}_{3}$ & ppmv & Jan 6-Mar 15,1976 & 1393 & 0 & 0.10 & 0.02 & 0.04 & 0.08 & $(1 \mathrm{hr})$ \\
\hline $\mathrm{co}$ & ppmv & Jan 8-Mar 15, 1976 & 1367 & 0 & 2 & 0.1 & 0.3 & 35 & $(1 \mathrm{hr})$ \\
\hline No & ppmv & Jan 6-Mar 15, 1976 & 1647 & 0 & 0.09 & $<.01$ & 0.02 & & \\
\hline $\mathrm{NO}_{2}$ & ppmv & Jan 6-Mar 15, 1976 & 1674 & 0 & 0.09 & 0.01 & 0.02 & 0.25 & $(1 \mathrm{hr})$ \\
\hline${ }^{\text {No }} x$ & ppmv & Jan 6-Mar 15, 1976 & 1647 & 0 & 0.11 & 0.02 & 0.04 & & \\
\hline TS & ppmy & Feb 25-Már 15, 1976 & 437 & 0 & 0.03 & $<.01$ & $<.01$ & & \\
\hline $\mathrm{H}_{2} \mathrm{~S}$ & ppmv & Feb 11-Mar 15, 1976 & 552 & 0 & 0 & 0 & 0 & 0.03 & $(1 \mathrm{hr})$ \\
\hline $\mathrm{SO}_{2}$ & ppmv & Feb 11-Mar 15, 1976 & 730 & 0 & 0 & 0 & 0 & & \\
\hline THC & ppmv & Jan 8-Mar 15, 1976 & 1367 & 1.4 & 5.1 & 1.9 & 2.8 & 0.5 & $(1 \mathrm{hr})$ \\
\hline $\mathrm{CH}_{4}$ & ppmv & Jan 8-Mar 15, 1976 & 1367 & 1.4 & 5.1 & 1.9 & 2.7 & & \\
\hline NMHC $^{a}$ & ppmv & Jan 8-Mar 15, 1976 & 1367 & 0 . & 1.1 & $<.1$ & $0.1=$ & 0.24 & $(3 \mathrm{hr})$ \\
\hline TSP & $\mu g / m^{3}$ & Jan 10-Mar 13, 1976 & 10 & 37 & 124 & 85 & & 100 & $(24 \mathrm{hr})$ \\
\hline
\end{tabular}

a Nonmethane hydrocarbons. 
of 0.05 ppmv $\mathrm{H}_{2} \mathrm{~S}$ at the East Mesa facility when the measuring point was directly downwind from a geothermalwell operation. These contributions by the Air Resources Board and the Environmental Protection Agency were performed on a cooperative basis at no cost to this program. Such measurements were extremely useful during our start-up time.

We have also collected several particulate-filter samples at various locations within the Valley. Analyses of these filters by neutron activation, $x$-ray fluorescence, and atomic absorption reveal the presence of the following elements: $\mathrm{Li}, \mathrm{Na}, \mathrm{Mg}, \mathrm{Al}$, $\mathrm{C} 1, \mathrm{~K}, \mathrm{Ca}, \mathrm{Sc}, \mathrm{Ti}, \mathrm{V}, \mathrm{Cr}, \mathrm{Mn}, \mathrm{Fe}, \mathrm{Co}$, $\mathrm{Ni}, \mathrm{Cu}, \mathrm{Zn}, \mathrm{Ga}, \mathrm{As}, \mathrm{Br}, \mathrm{Rb}, \mathrm{Sr}, \mathrm{Y}$, $\mathrm{Zr}, \mathrm{Mo}, \mathrm{Ba}, \mathrm{La}, \mathrm{Ce}, \mathrm{Nd}, \mathrm{Pb}, \mathrm{U}$, and Th.

\section{Source Measurements}

Part of our effort has been. directed toward measuring the noncondensable-gas emissions from the SGD\&E Geothermal Loop Experimental

\section{- Facility near Niland. The facility} processes the high-salinity geothermal fluids from deep wells by flashing hot water under pressure into steam in four progressively lowerpressure stages. The separated steam is scrubbed and subsequently condensed in heat exchangers where it heats a secondary fluid in a closed cycle system. The noncondensable gases present in the steam fraction are vented to the atmosphere through a 130-ft-tall stack, while the brine is returned to the geothermal reservoir by injection via another well. The noncondensable gas fraction was expected to consist primarily of $\mathrm{CO}_{2}$ and lesser amounts of other chemical species, with $\mathrm{H}_{2} \mathrm{~S}$ being the pollutant of primary interest from an environmental viewpoint.

Sampling and analysis of geothermal fluids are fraught with much difficulty because of high temperatures and pressures as well as the multiplicity of complex chemical reactions that may occur within the sampling train. The 1aboratories involved in this part of the program are: the Battelle Pacific Northwest Laboratory (BNWL), the LFE Environmental Analysis Laboratories (LFE); the U.S. Environmental Protection Agency in Las Vegas (EPA), and the Lawrence Livermore Laboratory (LLL). The chemical species of interest and the measurements made by each laboratory are given in Table 4. Considerable duplication of effort exists among the laboratories. This is specifically designed into the program because of the variety of analytical techniques that will be employed. A number of samples will be collected simultaneously for intercomparison 
Table 4. The chemical species that will be measured by each laboratory in the noncondensable gas emissions from the SDG\&E facility.

\begin{tabular}{|c|c|c|c|c|}
\hline Chemical species & LLL & LFE & BNWL & EPA \\
\hline Hydrogen sulfide & 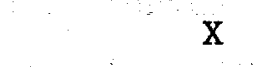 & $\mathrm{x}$ & $\mathrm{x}$ & \\
\hline Ammonia & $\mathrm{x}$ & $\mathrm{x}$ & $\mathrm{x}$ & \\
\hline Carbon dioxide & $\mathrm{x}$ & $\mathrm{x}$ & & \\
\hline Boron & $\mathrm{x}$ & $\mathrm{x}$ & . & \\
\hline Fluorides & $\mathrm{x}$ & $\mathrm{x}$ & $\mathrm{x}$ & \\
\hline Mercaptans & . & & & \\
\hline Hydrogen & $\mathrm{x}$ & & & \\
\hline Nitrogen & $\mathrm{x}$ & & & \\
\hline Total hydrocarbons & $\mathrm{x}$ & $\mathrm{x}$ & $\mathrm{x}$ & \\
\hline Methane & $\mathrm{x}$ & $\mathrm{x}$ & $\mathrm{x}$ & \\
\hline Mercury & & & $\mathrm{X}$ & \\
\hline Arsenic & & & $\mathrm{X}$ & \\
\hline Selenium & & & $\mathrm{x}$ & \\
\hline Radon & & $\mathrm{x}$ & & $\mathrm{X}$ \\
\hline Particles & & $\mathrm{x}$ & & \\
\hline
\end{tabular}

studies. A summary of most of the analytical techniques for each chemical species is shown in Table 5 .

Unfortunately, this effort has not yet yielded a large number of results. The operating characteristics of the SDG\&E facility have been most erratic since the June 1976 start-up. Furthermore, on several occasions when we attempted to sample the noncondensable emissions, the gas stream was significantly contaminated with water and brine; this caused extreme analytical difficulties. Thus, only a few measurements have been made.
These were made by LLL chemists who were operating the LLL Total Flow System adjacent to the SDG\&E facility. These two facilities are operating on the same well. Table 6 shows the range of concentrations of several chemical species that were measured. All of the $\mathrm{H}_{2} \mathrm{~S}$ measurements were made in the noncondensable emissions vented from the SDG\&E facility, while the $\mathrm{CO}_{2}, \mathrm{H}_{2}, \mathrm{~N}_{2}, \mathrm{CH}_{4}$, and $\mathrm{C}_{2} \mathrm{H}_{6}$ concentrations summarize measurements in the SDG\&E and the Total F1ow System noncondensable emissions. It should be valid to combine these 
Table 5. The analytical techniques used in the geothermal source measurements.

\begin{tabular}{|c|c|}
\hline Chemical species & Analytical t \\
\hline Hydrogen sulfide & $\begin{array}{l}\text { Electrolytic oxidation, specific ion electrode } \\
\text { flame photometry, lead acetate tape. }\end{array}$ \\
\hline Ammonia & Microwave spectrometry, specific ion electrode \\
\hline arbon dioxide & Mass spectrometry, gas chromatography. \\
\hline oron. & Specific ion electrode. \\
\hline Fluor & Specific ion electrode. \\
\hline ans & Microwave spectrometry. \\
\hline Hydro & Mass spectrometry. \\
\hline Nitrogen & Mass spectrometry \\
\hline ethane. & Mass spectrometry, gas chromatography. \\
\hline Mercury & Atomic absorption. \\
\hline Arsenic & DC plasma discharge. \\
\hline$\therefore \quad 2 \cdots$ & DC plasma discharge. \\
\hline Radon & Thermoluminiscent detection, alpha counting. \\
\hline articles & scence, atomic absorption: \\
\hline
\end{tabular}

data because the same geothermal well was tapped. The $\mathrm{H}_{2} \mathrm{~S}$ concentrations vary by at least a factor of 3 , from 1500 to 4900 ppmv. As expected, about 96 to $98 \%$ of the noncondensable gas is $\mathrm{CO}_{2}$. The contributions by $\mathrm{H}_{2}$, $\mathrm{N}_{2}, \mathrm{CH}_{4}$, and $\mathrm{C}_{2} \mathrm{H}_{6}$ are generally less than $1 \%$.

We will conduct more detailed analyses as soon as the SDG\&E facility becomes more operable: In addition, similar measurements will be made at the U.S. Bureau of Reclamation East Mesa facility, Union 0il geothermal test operations near Brawley, and at other sites that become operable during the period of this program.

\section{Airborne-Particle Studies}

The sampling and analyses of airborne particles will be performed by Investigators at the University of California at Davis under contract to LLL. The cost of the contract is 
Table 6. Concentrations of various chemical species measured in the noncondensable emissions by LLL.

\begin{tabular}{ccc}
\hline Species & $\begin{array}{c}\text { No. of } \\
\text { measure- } \\
\text { ments }\end{array}$ & $\begin{array}{c}\text { Concentration } \\
\text { (by volume) }\end{array}$ \\
\hline $\mathrm{H}_{2} \mathrm{~S}^{\mathrm{a}}$ & 11 & $1500-4900 \mathrm{ppmv}$ \\
$\mathrm{CO}_{2}{ }^{\mathrm{b}}$ & 4 & $96-98 \%$ \\
$\mathrm{H}_{2}{ }^{\mathrm{b}}$ & 4 & $<0.05-0.34 \%$ \\
$\mathrm{~N}_{2}{ }^{\mathrm{b}}$ & 4 & $0.2-0.7 \%$ \\
$\mathrm{CH}_{4}{ }^{\mathrm{b}}$ & 4 & $0.5-1.4 \%$ \\
$\mathrm{C}_{2}{ }_{6}^{\mathrm{b}}$ & 4 & $<0.03 \%$ \\
\hline
\end{tabular}

a The $\mathrm{H}_{2} \mathrm{~S}$ analyses were performed by an electrolytic oxidation technique at the sampling site immediately after sample collection.

b

These analyses were performed by mass spectrometry at LLL.

$\$ 100,000$. The tasks include the following:

- Continuous monitoring of particles at the six air-quality stations. The particles will be collected by impaction in three size groups. These are 0.1 to $0.6 \mu \mathrm{m}, 0.6$ to $3.6 \mu \mathrm{m}$, and 3.6 to $20 \mu \mathrm{m}$. Elemental analyses will be performed by ion-induced $x$-ray fluorescence: These data will form the basis for the statistical analyses of gas and particle correlations.

- Characterization of the elemental distributions in particles in source-enriched areas near geothermal operations, feed lóts, agricultural burning, fertilizer operations, as well as in particles transported across the southern border, etc.

The continuous monitoring at the fixed stations will be initiated during February 1977, while studies on the transport of particles across the border will begin during October 1976 .

The characterization of particles in source-enriched areas requires the development of portable sampling instrumentation that will perform particle-size separation between coarse and fine particles at low cost while delivering samples suitable for gravimetric and elemental determinations. Thus, the U.C. Davis investitators designed and built a two-stage stacked-filter unit for this purpose. This device uses two Nuclepore filters in series to effect separation of coarse and fine particles with a cut point at about $3 \mu \mathrm{m}$ aerodynamic diameter. The unit was tested and provided sharp separation between coarse and fine particles as indicated by elemental composition and confirmed by impactor studies. Table 7 illustrates the behavior of the stacked filter unit in this test. The unit, including pump, intake manifold, and support weighs less than $20 \mathrm{1b}$ and costs less than $\$ 100$. Eight such units are being built for this program. 
Tab1e 7. Elemental composition of coarse and fine particles as separated by a stacked filter unit.

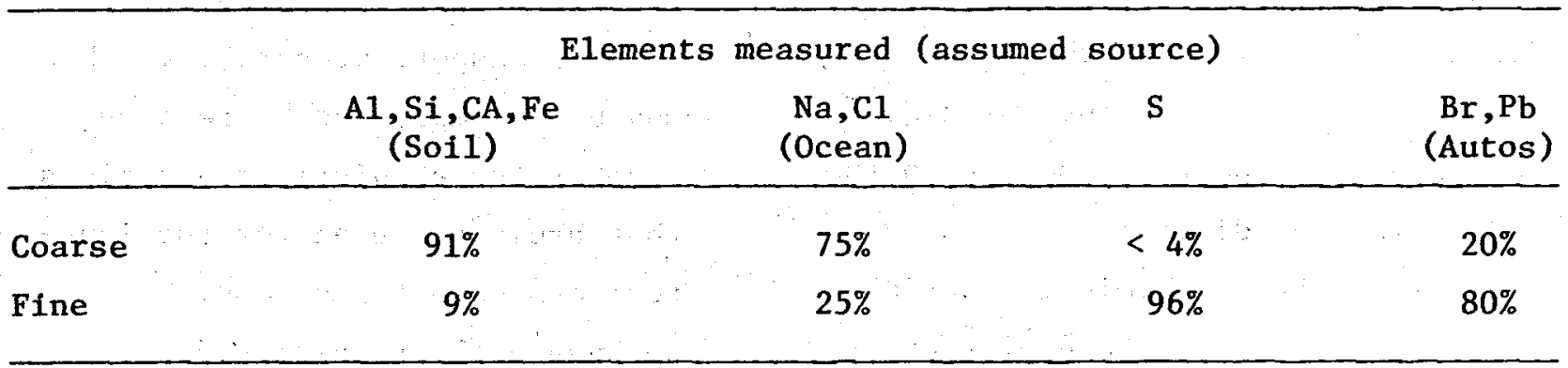

In addition to these studies, we will also collect regular 24-hr $\mathrm{Hi}$ Vol samples at each of the six stations for mass-loading determinations. Rockwell International will perform these analyses under a $\$ 1720$ contract.

We also expect to acquire a virtual impactor with a cut point of about $2 \mu \mathrm{m}$ aerodynamic diameter for a more detailed investigation of sulfur speciation in the small size fraction. Investigators from Brookhaven National Laboratory and LLL will perform the analyses on a limited number of samples.

Atmospheric Transport Modeling

To develop a predictive capability for estimating the impact on air quality resulting from the development of a given geothermal-resource region, it is necessary to resort to modeling techniques. This will be accomplished with the use of LLL advanced three-dimensional flow models. These models utilize regional topography and measured wind information to produce interpolated and extrapolated wind fields on an Eulerian grid superimposed over the topography. The wind fields are then adjusted for mass consistency to eliminate artificial convergences and divergences. These flow fields are then used as input to either the three-dimensional advection-diffusion particle-in-cell code (ADPIC), the two-dimmensional coupled-transportkinetics code (LIRAQ), or the threedimensional reactive-plume model. The particle-in-cell code is a numerical, three-dimensional, Cartesian, particle-diffusion code capable of computing the time-dependent dispersion of air pollutants under various conditions, including distorted advection fields, calm conditions, and complex topography. The code solves the three-dimensional advection-diffusion equation by the pseudo-velocity technique for a given mass-consistent wind field. This 
code is currently operational at LLL. The LIRAQ code also utilizes numerical techniques to solve the advectiondiffusion equation and the effects of photochemistry. Using the timedependent transport parameters in the two horizontal dimensions and a prescribed set of chemical reactions, the code calculates the evolution and transport of a number of chemically reactive species. This code is a1so operationa1 at LLL at this time. The reactive-plume model, presently under development by other programs at LLL applies the technique of fractional steps to the solution of the three-dimensional transport equation as well as incorporating chemical kinetics.

These codes have been developed specifically for assessing the impact resulting from relatively short-term releases on the order of hours to days. To simulate extended periods on the order of a year, the following two options are being explored by other programs:

- Stratify the meteorological data to reduce the amount of data required to present a $1-y r$ (or longer) data base without loss of informational content. This may be accomplished by categorizing the frequency and type of meteorological conditions and their order of occurrence during the period of interest.
- Reduce the running time of the code without loss of its capability for realistically simulating the major transport properties. This may be accomplished by removing some of the sophisticated options that are not needed for the longterm assessment prob̀lems.

We have not' yet initiated any effort directly related to the Imperial Valley Environmental Program in the modeling area. However, this work should commence during the coming months when the air-quality field program becomes fully operational.

Summary

The objective of the program is to predict the potential change in air quality within the Imperial Valley resulting from the possible development of geothermal resources. Thus, the program has been designed to characterize the current state of the atmosphere of the Valley from an airquality point of view and to measure the atmospheric transport properties on a Valley-wide basis. This will be accomplished by the fielding of six fixed-1ocation air-quality and meteorological stations and a mobile laboratory to make measurements of gaseous and particulate pollutants. Geothermal source emissions of noncondensable gases are also being measured. These data may then serve 
as input to our atmospheric transport models to predict the potential changes in air quality resulting from the operation of an array of postulated geothermal power piants.

We are currently installing the six air-quality stations in the Valley. The Niland station (No. 1) became operational during June 1976. Three stations will be operable during November 1976 with the remainder going on-1ine toward the end of $\mathrm{CY}$ 1976. The mobile laboratory will become available for air-quality measurements by Ju1y 1977. Geotherma1source measurements at the SDG\&E facility at Niland are underway with similar measurements to be made at the East Mesa KGRA as well as other sites where geothermal development may occur during the duration of the program. The atmospheric modeling; utilizing existing three-dimensional LLL transport models, will be performed during 1977 and 1978.

The State of California Air Resources Board diverted their mobile air-quality laboratory during January to March 1976 to the northern part of the Imperial Valley to support this program. Their data, summarized in Table 3 , show that the concentrations of gaseous pollutants are generally low, while particulate loading is fairly high. Measurements of $\mathrm{H}_{2} \mathrm{~S}$, $\mathrm{So}_{2}$, and $\mathrm{O}_{3}$ have also been made by our fixed air-quality station near
Niland (No. 1) since June 1976. Its data agree well with those of Table 3. Simllarly, the U.S. Environmental Protection Agency (Las Vegas) has confirmed that the $\mathrm{H}_{2} \mathrm{~S}$ and $\mathrm{SO}_{2}$ concentrations within the northern part of the Valley are less than 0.005 ppmv. Measurements of $\mathrm{H}_{2} \mathrm{~S}$ concentrations made by the EPA at the East Mesa KGRA also revealed concentrations that were generally less than 0.005 ppmv except when the measuring point was directly downwind from a geothermal-well operation. At such times concentrations as high as 0.05 ppmv were detected.

Preliminary source measurements of the noncondensable gases emitted from the SDG\&E facility indicate that roughly $97 \%$ is $\mathrm{CO}_{2}$ with lesser amounts of $\mathrm{H}_{2} \mathrm{~S}, \mathrm{~N}_{2}, \mathrm{H}_{2}$, and $\mathrm{CH}_{4}$. The $\mathrm{H}_{2} \mathrm{~S}$ concentrations vary considerably. A range of 1500 to 4900 ppmv has been measured.

Much of the work will be performed by organizations other than LLL. A summary of the contracts. let by the air quality program is given in Table 8. In addition, the Air Resources Board and the EPA will provide additional measurements periodically at no cost to this program. With inhouse funding the EPA will also be responsible for conducting a qualityassurance program covering the operation of the six air-quality stations. EG\&G is presently developing its 
capability, with internal funds; to perform airborne measurements of selected gaseous and particulate pollutants. This capability will provide a means for obtaining vertical profiles of pollutants throughout the Valley, a most valuable addition to the program. Sulfur speciation on particles will be investigated on a limited number of samples by investigators at Brookhaven National Laboratory and Lawrence Livermore Laboratory. 
Table 8. Contracts let by the air-quality program.

\begin{tabular}{ccccc}
\hline Name & $\begin{array}{c}\text { Organization } \\
\text { (principal } \\
\text { investigator) }\end{array}$ & $\begin{array}{l}\text { Duration } \\
\text { of work }\end{array}$ Cost & Task \\
\hline
\end{tabular}

Particulate

characterization

University of

California/Davis

(T.A. Cahill/

R.G. F1occhini)

$10 / 76-4 / 78$

$\$ 100 \mathrm{~K}$

Perform elemental analyses of particle samples collected at the six fixedlocation air-quality stations. The analyses will define the daily averaged elemental concentrations for each of three particle-size groups $(0.1-0.65 \mu \mathrm{m}$, $0.65-3.6 \mu \mathrm{m}$, and $3.6-20 \mu \mathrm{m})$.

The work will include the characterization of elemental distributions in airborne particles as a function of particle size and time in the vicinity of specialized sources such as agricultural operations, transport across the southern border, etc.

Gas calibration

State of California Air and Industrial Hyglene Lab.

(E. Jeung)

LFE Environmental Analysis Lab.

(A. Soinski) measurements (?)

Rockwe11 International (E. Perry)
9/76-10/77 \$25 K Perform calibration of span-gas cylinders, gas analyzers, and LLL-constructed gasdilution systems. Perform field audit of LLL air-quality instruments within the Imperial Valley.

6/76-12/77 \$ $15 \mathrm{~K}$. Perform chemical analyses of the noncondensable emissions from geothermal operations. These analyses include the determination of hydrogen sulfide, ammonia, carbon dioxide, boron, fluorides, total hydrocarbons, methane, radon, and particles.

11/76-12/77 $\$ 1.72 \mathrm{~K}$ Perform total mass measurements on filter stations. samples collected at the six fixed 
Table 8 (cont.).

\begin{tabular}{ccccc}
\hline Name & $\begin{array}{c}\text { Organization } \\
\text { (principal } \\
\text { investigator) }\end{array}$ & $\begin{array}{l}\text { Duration } \\
\text { of work }\end{array}$ & Cost & Task \\
\hline Manpower assistance & $\begin{array}{l}\text { Imperial Valley } \\
\text { Air Pollution } \\
\text { Control District } \\
\text { (J. Taylor) }\end{array}$ & $11 / 76-12 / 77$ & $\$ 16 \mathrm{~K}$ & $\begin{array}{l}\text { Provide part-time manpower to assist in } \\
\text { the routine operation of the six fixed } \\
\text { air-quality stations. }\end{array}$ \\
\hline
\end{tabular}


WATER QUALITY

Kenneth D. Pimentel and Neil B. Crow

\section{Overview of Water Quality Study}

One of the potentially significant environmental effects of geothermal development in the Imperial Valley is the possible contamination of surface waters by geothermal brines. Because these brines are moderately to highly saline, the major effect would be an increase in salinity. A problem exists in differentiating any such contamination, because the surface water used in the Imperial Valley is rather highly mineralized water from the Colorado River, and the agricultural practices result in the leaching of salts from the soils into drainage channels. It is conceit $\lrcorner$ ble that a transient pulse of salinity in drainage water resulting from leaching of agricultural

lands could be confused with geothermal contamination. For these reasons, we are taking water samples for chemical analysis to establish baseline levels of salinity and patterns of trace-element composition. It is believed that geothermal brines have a different composition from surface water that will enable us to distinguish between the two kinds of water.

Thus far our program has concentrated on collection of grab samples and their chemical analysis essentially data gathering. In January 1976, we established sampling networks in the Salton Sea goethermal field area, centered on the SDG\&E/ ERDA Geothermal Test Facility, and collected samples on six trips before operations at the Test Facility commenced. We also have collected samples on a Valley-wide network. During the summer, grab-sampling networks were designed and field checked, and in October 1976 sampling began in the three other major geothermal areas in the Imperial Valley: North Brawley, Heber, and East Mesa. Progress has been made toward identifying a qualified contractor to perform routine chemical analyses on these samples. In November, we will finish selecting an in situ water-quality-monitoring system and will place an order for four to six units. A mobile waterquality van has been ordered and will be equipped for field use as soon as received. Task descriptions of our program are summarized in the following section. Detailed discussions of each of these tasks follow in the remaining sections.

Summary of Progress on Project Tasks

\section{Water-Sampling Program}

Valley-wide sampling program - Instituted sampling of Valley-wide network January 1976. Network was initially sampled on a 6-week basis. 
Site-Specific Sampling Program -

Sampling instituted at the Salton Sea Geothermal Field area, centered on SDG\&E/ERDA Geothermal Test Facility, in January 1976. The network was first sampled on a 3-week basis. Sampling networks for the North Brawley, Heber, and East Mesa KGRAs have been designed and were initiated during October 1976.

\section{Recording Meter Network}

It was decided that the recording conductivity meters being constructed at LLI early in the year would not be adequate to obtain the necessary data. Presently, commercial instrumentation to measure and record a number of water-quality parameters is being investigated, and an order for four to six units will be placed in November. The units will be used to monitor variation of water quality with time, primarily in local monitoring networks as well as in intensive studies anywhere in the Valley.

\section{Ground-Water Monitoring}

The first ground-water monitoring will take place at the East Mesa geothermal field, with samples taken from witness wells drilled by the Bureau of Reclamation near goethermal wells. A program plan for installation and sampling of monitoring wells at the Salton Sea, North Brawley; and the Heber geothermal fields is being prepared.

\section{Full Water-Quality-Monitoring} Station (Mobile)

Orders have been placed for a vehicle and equipment for this station. When the vehicle and equipment arrive, they will be moved to the Imperial Valley as soon as the mobile unit is usable. Added equipment will be installed as it is received.

\section{Data Gathering}

Data is being acquired from our own field program and from outside agencies such as the U.S. Geological Survey (USGS) Water Resources Division, the Imperial Irrigation District, and others.

Data Analysis and Storage

All available data has been

' placed in the IVEP data-storage and retrieval system. A program plan is in preparation to interpret data, with emphasis on pattern recognition and modeling techniques, using digitized data systems.

Imperial Va1ley Water-System Modeling

A program plan is in preparation. We are investigating the feastbility of intensive study of small regions of the Imperial Valley, which may allow scaling-up of models to predict behavior of the Valley as a whole.

Salton Sea Study

Because of manpower shortage, a water quality study of the Salton Sea 
is not being pursued actively. The program-plan preparation is being deferred for the present.

\section{Chemical Support}

We are establishing qualitycontrol procedures, using standards from EPA and the USGS Water Resources Division. We are evaluating the performance of a number of candidate commercial analytical laboratories; when the results are received, we will be able to choose one for the bulk of our analytical work. We are also investigating alternate methods of multielement analysis to be done at LLL, which hopefully will provide less costly methods of obtaining accurate data.

Detailed Description of Progress on Project Tasks

\section{Water Sampling Program}

Valley-Wide Surface-Water-Sampling Network - Samples have been taken on the Valley-wide network, shown in Fig. 1, since January-1976. Some of these samples have been sent to chemical laboratories for analysis. Not all results have yet been received. At first samples were taken monthly, then every 6 weeks, and are now being collected again on a monthly basis.

Site-Specific Networks - In addition to the Valley-wide sampling network, site-specific grab-sampling networks have been established in the four major KGRAs in the Valley: Salton Sea, North Brawley, Heber, and East Mesa. These are shown as insets in the map in Fig. 2, and shown individually in Figs. 3, 4, 5, and 6 . Salton Sea Geothermal-Field Area - The first site-specific network for water samples was established in the Salton Sea Geothermal Field with the first samples taken in January 1976. This area was chosen because of the impending start-up of the SDG\&E/ERDA Geotherma1 Test Facility located in the area. It was also decided that the network should include the nearby test facilities situated at the Sinclair \#4 we11, approximately $1 \mathrm{mi}$ south of the Geotherma1 Test Facility. The Sinclair \#4 facility was operated by a consortium of Southern California Edison Co., Southern Pacific Land Co., and Phillips Petroleum Co.; the facility includes extensive brine-evaporation ponds that have been used intermittently over the past 10 years. The sampling sites for the Salton Sea KGRA are shown in Fig. 3.

The philosophy in choosing sampling sites was straightforward; for each of the two major types of water (irrigation water and drain water), sampling sites were established upstream and downstream of the geothermal operations. The upstream measurement provides a baseline of water 


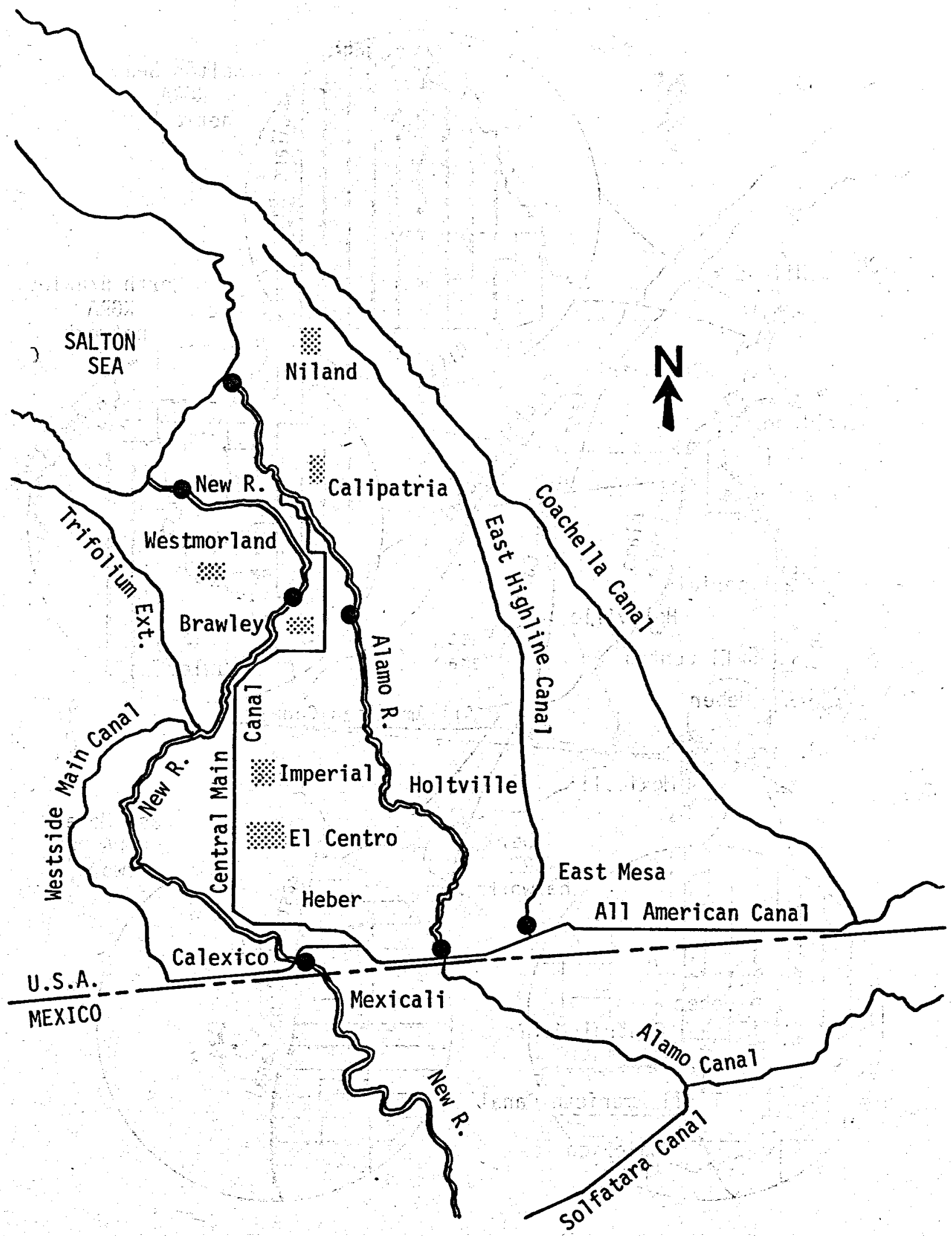

Fig. 1. Valley-wide water-sampling sites. 


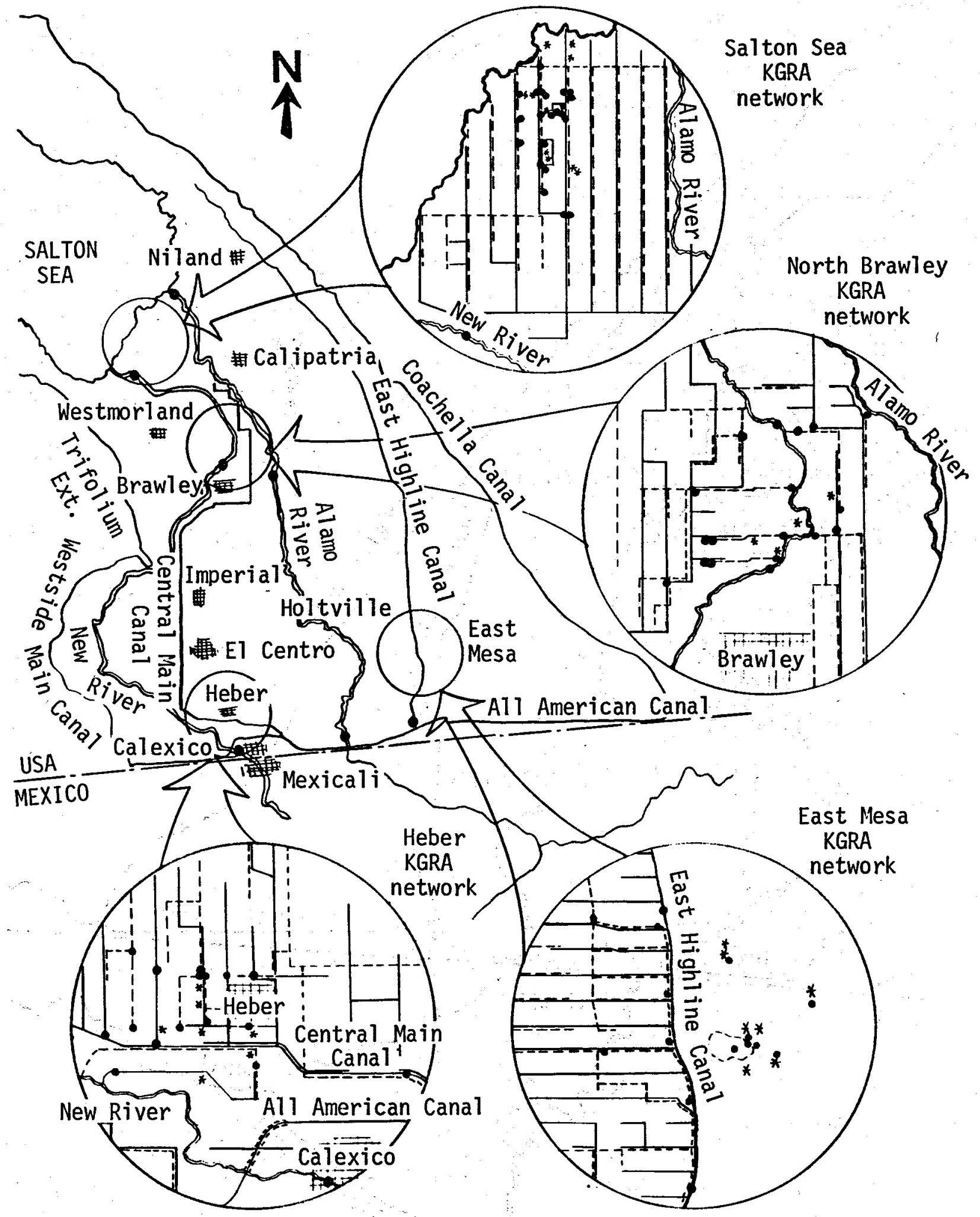

Fig. 2. Site-specific water-sampling networks in the four major KGRAs. 


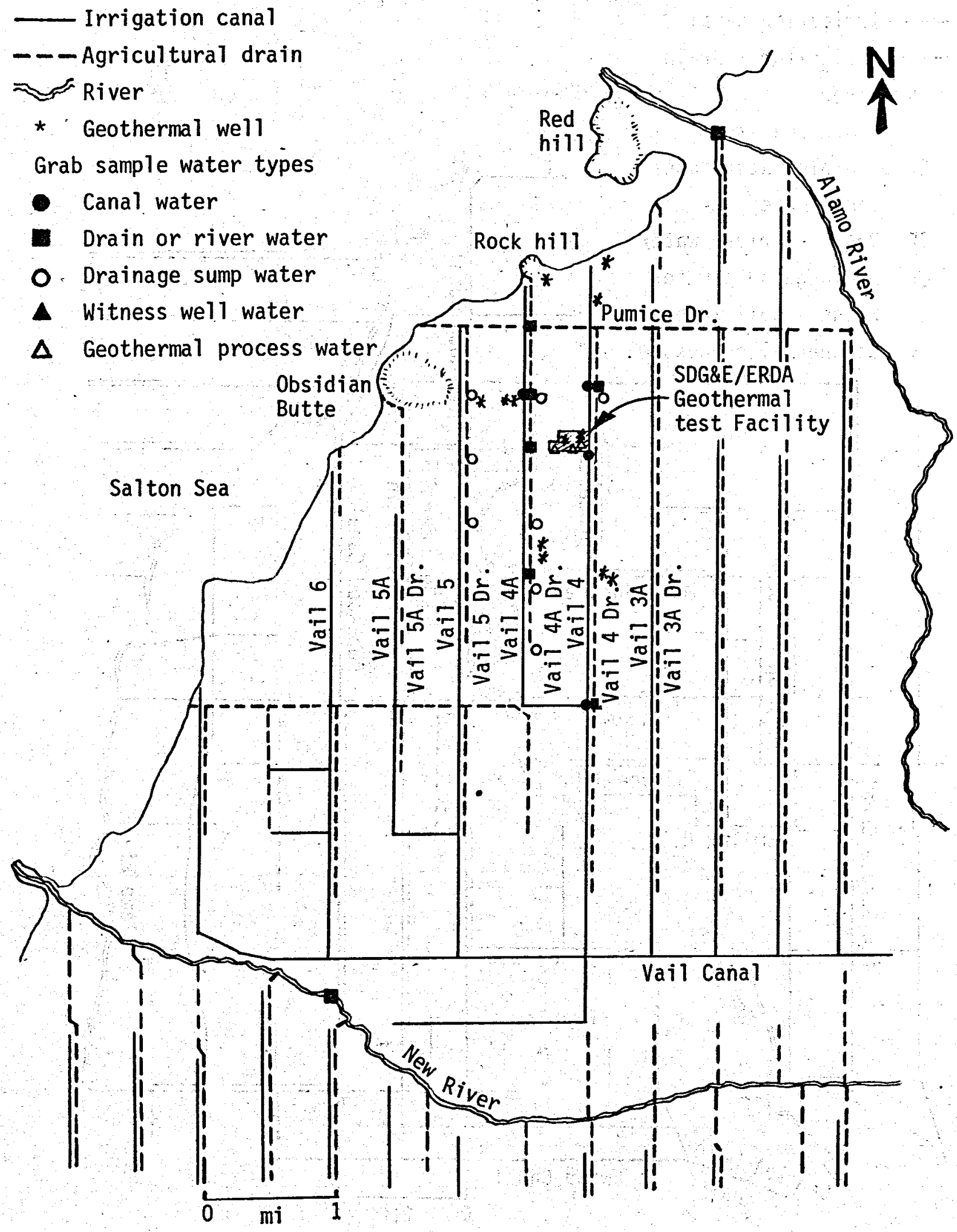

Fig. 3. Salton Sea KGRA water-sample sites. 


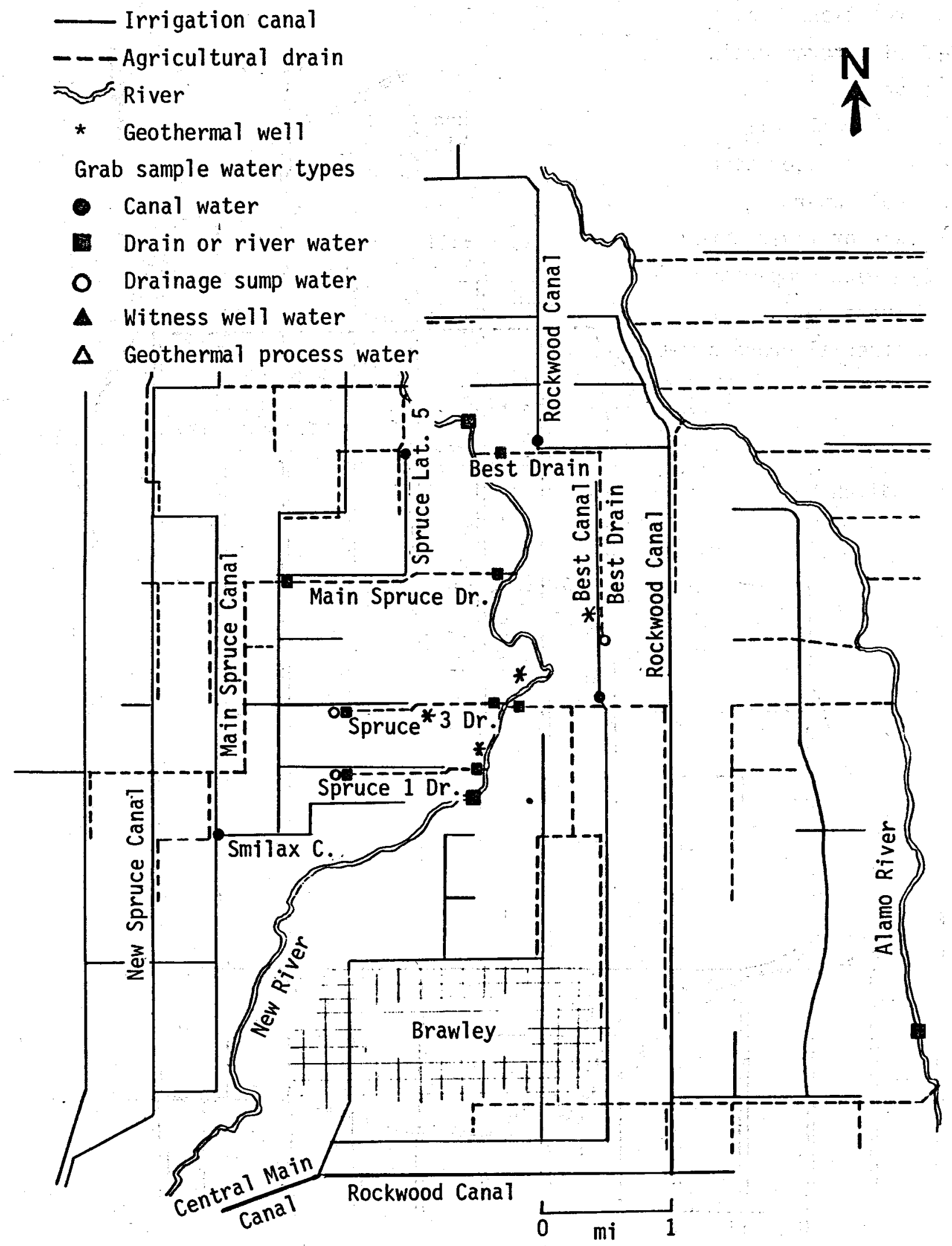

Fig. 4. North Brawley KGRA water-sample sites. 


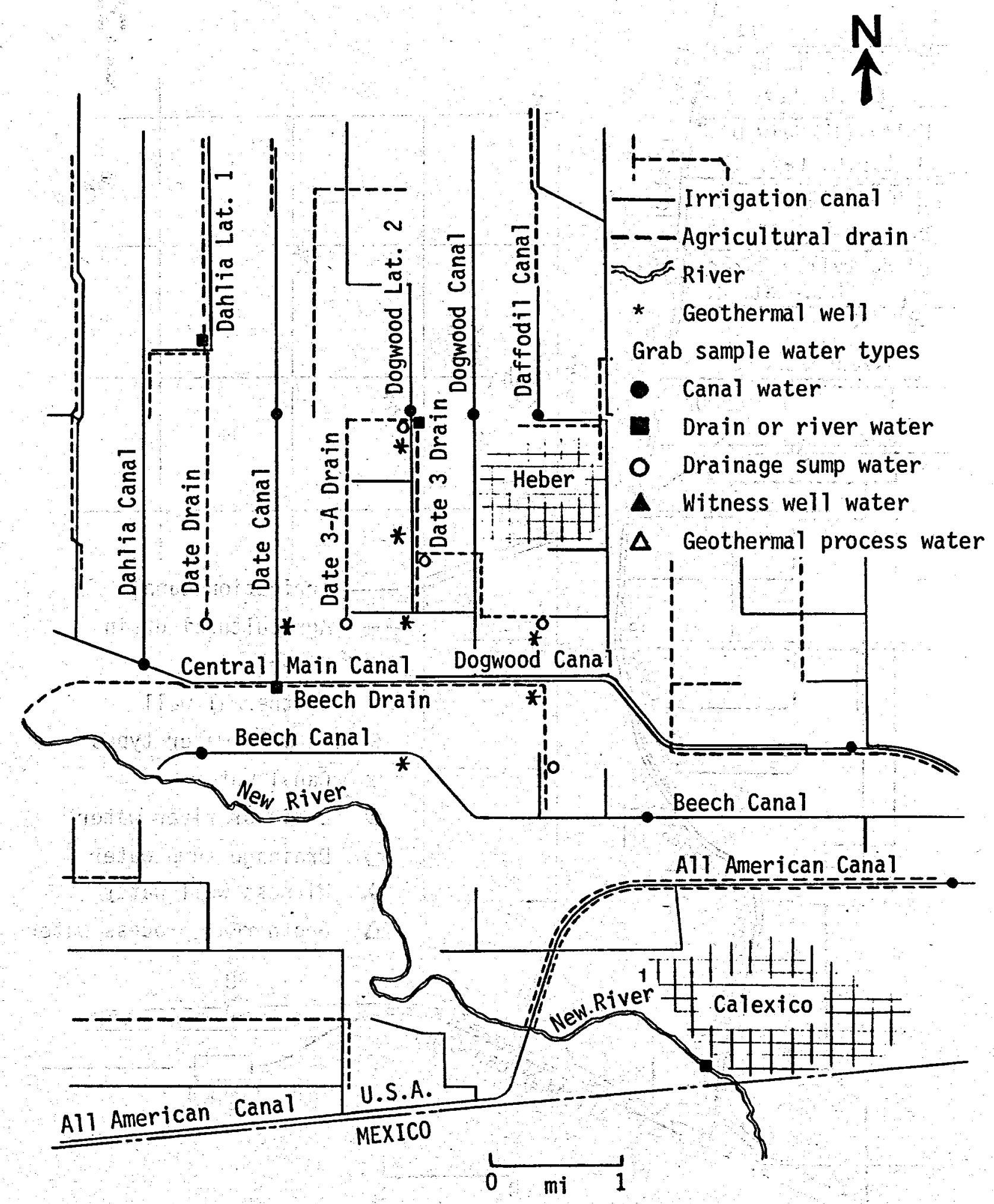

Fig. 5. Heber KGRA water-sample sites. 


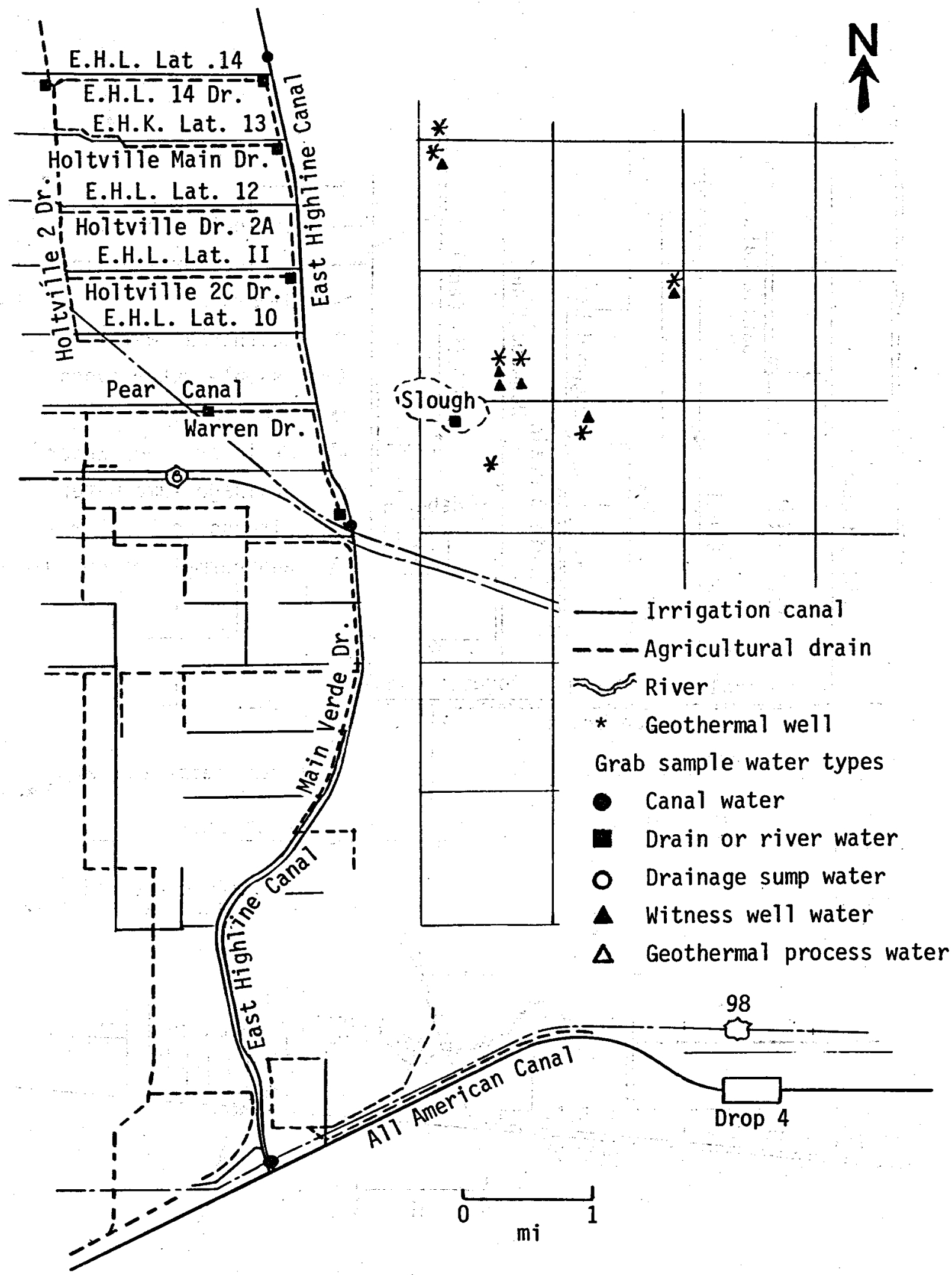

Fig. 6. East Mesa KGRA water-sample sites. 
quality in the specific watercourse sampled, and the measurement downstream indicates any additions to the water as it passes through the area. Clearly, geothermal effluents might not be the only additions to the water; baseline measurements before development have provided evidence of conditions that existed prior to startup of the SDG\&E/ERDA Facility.

Water samples have been taken regularly since January; at first, sampling was carried out at 3-week intervals and more recently at 4-week intervals. Sampling techniques are based on generally accepted practices as established by the USGS and EPA. At this time, a number of samples taken on the sampling network have been analyzed chemically. Additional samples are currently being analyzed. The list of elements for which analyses were made is shown in Table 1.

Analyses typical of those received to date are shown in Table 2. Because our purpose here is comparison of analytical data obtained from samples of water with widely differing salinity, the data are presented as percent of total dissolved solids (TDS), which enables rapid comparison among samples. In an appendix to this section, full analyses of these samples are presented.

The normal surface water of the region is represented by the samples of irrigation water, agricultura1-drain
Table 1. Chemical analyses of water samples. Complete list is for initial survey data; those with dots (•) are for routine analyses.

\begin{tabular}{lr}
\hline$-\mathrm{Na}$ & $\bullet \mathrm{As}$ \\
$-\mathrm{K}$ & $\mathrm{Ba}$ \\
$-\mathrm{Ca}$ & $\mathrm{Cd}$ \\
$-\mathrm{Mg}$ & $\mathrm{Co}$ \\
$-\mathrm{Li}$ & $\mathrm{Cu}$ \\
$-\mathrm{Cl}$ & $\mathrm{Fe}$ \\
$\mathrm{CO}_{3}$ & $\mathrm{Hg}$ \\
$\mathrm{HCO}_{3}$ & $\bullet \mathrm{Mn}$ \\
$-\mathrm{SO}_{4}$ & $\mathrm{Ni}$ \\
$-\mathrm{SiO}_{2}$ & $\mathrm{~Pb}$ \\
$\mathrm{NO}_{3}$ & $\bullet \mathrm{Rb}$ \\
$\mathrm{NH}_{4}$ & $\mathrm{Se}$ \\
\hline $\mathrm{B}_{\mathrm{F}}$ & $\bullet \mathrm{Sr}$ \\
\hline
\end{tabular}

Total dissolved solids, specific conductance, temperature, and $\mathrm{pH}$.

water, and Salton Sea water. These have somewhat similar characteristics, though the drain water and Salton Sea water are progressively enriched in sodium chloride relative to the irrigation-source water. The analysis of geothermal brine shows a strikingly different compositional profile, being high in potassium relative to sodium and very low in sulfate relative to the surface waters. The brine also contains significant quantities of 
Table 2. Chemical analyses of selected Imperial Valley waters (values shown in percent of total dissolved solids unless otherwise noted).

\begin{tabular}{|c|c|c|c|c|c|}
\hline $\begin{array}{r}\text { Chemical } \\
\text { parameter }\end{array}$ & $\begin{array}{l}\text { Irrigation } \\
\text { canal }\end{array}$ & $\begin{array}{l}\text { Agricultural } \\
\text { drain }\end{array}$ & $\begin{array}{l}\text { Contaminated } \\
\text { drainage } \\
\text { sump }\end{array}$ & $\underset{\text { brine }}{\text { Geothermal }^{1}}$ & $\begin{array}{l}\text { Salton } \\
\text { Sea }\end{array}$ \\
\hline $\mathrm{Na}$ & 20.4 & 20.8 & 15.1 & 21.9 & 28.3 \\
\hline $\mathrm{K}$ & 0.71 & 0.29 & 2.7 & 5.60 & 0.46 \\
\hline $\mathrm{Ca}$ & 9.7 & 7.5 & 14.3 & 10.1 & 2.57 \\
\hline $\mathrm{Mg}$ & 2.1 & 2.96 & 0.94 & 0.276 & 2.90 \\
\hline$\therefore$ & 0.0095 & 0.0058 & 0.069 & 0.129 & 0.000086 \\
\hline Mn & 0.00095 & 0.0064 & 0.21 & 0.44 & 0.000027 \\
\hline $\mathrm{C} 1$ & 19.0 & 24.2 & 50.9 & 58.0 & 40.5 \\
\hline $\mathrm{SO}_{4}$ & 31.8 & 35.7 & 2.87 & 0.0071 & 22.0 \\
\hline $\mathrm{Ba}$ & 0.0095 & 0.002 & 0.0025 & 0.41 & $<0.0027$ \\
\hline $\mathrm{Rb}$ & $<0.0002$ & $<0.0004$ & 0.0027 & - & - \\
\hline $\mathrm{Zn}$ & 0.00095 & 0.0003 & 0.047 & 0.26 & 0.00017 \\
\hline $\begin{array}{l}\text { Total dissolved } \\
\text { solids, mg/l }\end{array}$ & 1,052 & 5,136 & 48,106 & 266,557 & 37,082 . \\
\hline $\begin{array}{l}\text { Specific conductance, } \\
\mu \mathrm{mhos} / \mathrm{cm} \text { at } 25^{\circ} \mathrm{C}\end{array}$ & 1,650 & 6,700 & 75,000 & - & 42,100 \\
\hline $\mathrm{pH}$ & 8.2 & 7.5 & 6.7 & 5.3 & 7.7 \\
\hline $\mathrm{Na} / \mathrm{K}$ ratio & 28.7 & 71.3 & 5.5 & 3.9 & 61.0 \\
\hline
\end{tabular}

1. California Department of Water Resources, Geothermal Resources and the Water Resources of the Salton Sea Area, Bulletin 143-7, (1970). 
lithium, an element so unusual in ordinary water that it is used as a tracer in groundwater studies.: Additionally, the brines are high in manganese and zinc. The $\mathrm{pH}$ of the brines is about 5, while the average $\mathrm{pH}$ of surface water is near 8 .

In the process of sampling, we encountered a sump with water containing an unusually high concentration of dissolved solids. This sump, Sump 116 , is adjacent to an old geothermalbrine evaporation pond that is believed to be leaking into the adjacent soils. The sump is located near the northwest corner of the sinclair \#4 pond on Boyle Road 1/2 mi north of Lindsey Road. The anomalous nature of this water is shown in Fig. 7, which shows electrical conductivities determined at sampling stations in the Salton Sea KGRA. Conductivity is directly related to total dissolved solids. It should be noted that the quantity of water flowing into the sump was sma11. It was determined that the sump accumulates water from a tile system draining the field immediately east of the pond (to the right in the picture). Analysis of the water indicates the pattern of elements to be anomalous relative to the normal surface water.

We believe that the anomalous character of the contaminated water presents us with a powerful tool for detection of brine in surface water in the Salton Sea field area. It is believed that the presence of a substantial amount of lithium in a surface-water sample would be strongly suggestive of an admixture of geothermal brine. If, in addition, the analysis of a sample were to show a low $\mathrm{Na} / \mathrm{K}$ ratio, high manganese and zinc, low sulfate, and a $\mathrm{pH}$ somewhat more acidic than normal, we could say with high confidence that contamination of the water by geothermal brine had occurred. This tool is specific to the Salton Sea geothermal field area; we have very little information about brines at other fields. Caution is necessary in extrapolation to other areas. We must obtain brine samples from each field to determine whether the ratios of elements are similar to those seen at the Salton Sea field area. If some of these characteristics are typical of the brines in other areas, then very probably we can use a similar fingerprint.

Other geothermal field areas We have designed water-sampling networks for the other KGRAs in which geothermal activity is occurring; these are at North Brawley, Heber, and East Mesa. The stations have been field checked, and the first samples will be taken during October 1976. The networks are shown on Figs. 4, 5, and 6. Implementation of these site-specific networks will extend 


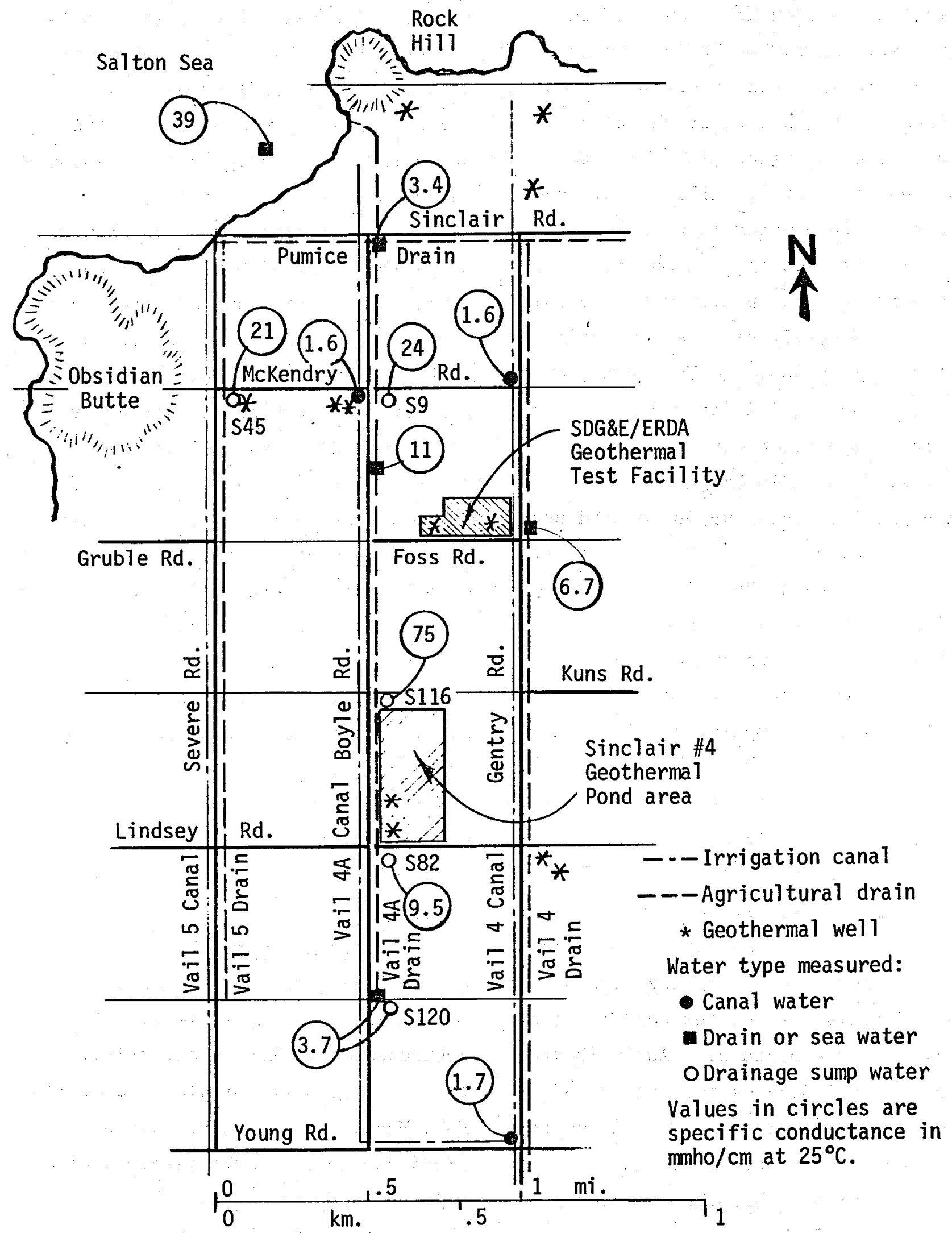

Fig. 7. Specific conductance of water samples, Salton Sea KGRA, February 1976, mmho/cm at $25^{\circ} \mathrm{C}$. 
detailed sampling to the other active KGRAs in the Imperial Valley, This will provide extensive baseline data about water quality, especially with regard to trace metals, for all geothermal areas likely to see extensive development. Note that a number of witness wells are to be sampled at East Mesa; unlike the irrigated portion of the Imperial Valley, there is no surface-water system of canals and drains east of the East Highline Cana1. However, there are better groundwater aquifers than are characteristic of the other KGRAs. Groundwater sampling will be discussed in more detail in a later section of this report.

\section{Recording Meter Network}

The design and implementation of a recording meter network in the Salton Sea KGRA and in other areas of the Imperial Valley has been beset with budgetary, manpower, and scheduling problems. Finally, in October 1976, we are seeing outside vendors and actively seeking quotations. $A$ proposal is in hand from one supplier with a trip scheduled for October 13 that should result in two more proposals from other suppliers. By the end of October, we will have decided on the equipment we need and can afford.

We have two recording conductivity-/temperature-meter systems in the final stages of construction at LLL. But since it was decided that their original design was inadequate and because of manpower shortages that have delayed their completion, we decided to look outside the laboratory to find what was available commercially. We now hope to put together four to six units for monitoring tempearture, specific conductance, $\mathrm{pH}$, flow rate, turbidity, and some specific ions. Placement of these monitoring-system units will be in the site-specific geothermal areas: Salton Sea field, North Brawley, Heber, and East Mesa. To exploit their portability, we hope to use them also in intense short-term studies that will assist in the subsequent redesign of the site-specific grab-sampling networks, to add or eliminate grab-sampling sites, and to better determine adequate grabsampling frequency. The two simpler systems in construction at LLL will be completed for use until the commercial units are obtained.

\section{Groundwater-Monitoring System}

Sampling of observation wells near the production we1ls at East Mesa, to begin in October, wil1 be the first sampling of groundwater in this program. The central part of the Imperial Valley, where the other KGRAs are situated, is underlain largely by lake beds, primarily fine silts and clays, at the depths to which groundwater wells are drilled. Because these sediments are relatively impermeable, 
yields from the few wells drilled in the vicinity of the Salton Sea, North Brawley, and Heber KGRAs are very small. Furthermore, because the fine-grained sediments are retentive of salts, the salinity of the water produced from the wells is so high - from 3000 to $10,000 \mathrm{ppm}$ TDS - that the water is not of beneficial use. At least one witness well in each KGRA will be constructed, both to document the baseline water quality in the immediate vicinity of possible geothermal production and to determine if any of the wells are leaking into the near-surface groundwater at a rate sufficient to contaminate the surface water into which the groundwater may flow. Such wells will also determine if any locally permeable rocks exist in the vicinity of the KGRAs that might contain higher quality water. These wells will be drilled to a depth of 100 to $200 \mathrm{ft}$, and cased with slotted plastic so that any water present in the rocks will drain into them. They will be sampled on the same basis as the surface-water channels in the site-specific network.

At East Mesa, where the nearsurface rocks are more permeable, ground-water sampling will be a major part of the site-specific sampling program. Because the witness we1ls are very small in diameter, it may be necessary to develop special sampling techniques, to be based on experience, for the wells. Sampling is to commence in October 1976. Mobile Water-Quality Laboratory We are presently in the process of obtaining and equipping a mobile laboratory to enable us to make chemical analyses at the time of collection, and to preserve samples more effectively for more accurate determinations in regular laboratories. We would like to measure some elements, such as nitrates, ammonia, and dissolved gases, that are ephemeral and disappear rapidly after the sample is taken. Analysis at the time of sampling will produce better results for such elements. Other elements can be measured in the field, using equipment in the van. Facilities will be installed in the van to preserve elements in the samples that might change in concentration with time unless handled in special ways. This will make possible laboratory analysis of biological parameters, for example, by refrigerating appropriate samples.

An order for the basic vehicle was placed in August 1976; capital equipment, including a power plant, refrigerator, and sampling and analytical equipment, was ordered early in September: Upon delivery of the truck, working tables and equipment 
shelves and racks will be installed, together with insulation and air conditioning to control the high temperatures characteristic of the Imperial Valley. As soon as the unit is equipped sufficiently to support sampling, it will be moved to the Imperial Valley. As other kinds of equipment are received, they will be installed in the unit.

\section{Data Gathering}

Large numbers of water samples have been taken in the Imperial Valley. Most of these have been taken and analyzed by two organizations, the Imperial Irrigation District (IID) and the Water Resources Division of the U.S. Geological Survey. The IID data include over 15 years of analyses of the common constituents and 26 years of TDS measurements at a number of points in the Valley. However, there are no trace-metal data. The U.S. Geological Survey data have been accumulated for several years and Include measurements of some trace metals We have contacted the responsible individuals in the USGS, and it is apparent that the data can be obtained in a digitized format compatible with the IVEP data-storage and management system.

We plan to continue our efforts to obtain data from all available sources.
Data Analysis

Analysis of initial analytical chemical results from grab samples taken in Imperial Valley has made apparent the need for digital techniques; the amount of data being accumulated is overwhelming and impossible to interpret by hand. Sorting, searching, and statistical routines are now being sought to aid in interpretation of the water-quality data. However, patterns are showing up that indicate surface-water contamination by geothermal fluids, as mentioned previously. Furthermore, initial results have shown which chemical elements are of importance and which can be eliminated from routine analyses; see Table 1 .

Pattern recognition and modeling are seen as important tools for understanding the water-quality data being generated and, indeed, in refining and reorienting the waterquality data being taken. We are also evaluating such techniques.

Modeling and Simulation

Mathematical modeling, and computer simulation with these models, is seen as an important part of the water-quality study, as well as all other elements of the IVEP. Models of surface and groundwater hydrology are now being sought to better understand the implications of geothermalpower development on water-quality and 
water-resource allocation problems. A direct product of modeling should be a determination of adequate grabsampling strategies - spatial and temporal frequency - for continued monitoring in the Imperial Valley. Uses of models in resource planning include testing various cooling-water supply/demand scenarios on a model of the Valley water system. Impacts on the drain-water quality and the Salton Sea are to be studied using models. For these reasons, modeling is thought to be of such importance that initial contacts have been made with a group of outside consultants experienced in water-quality and water-management models to advise us of how to proceed with construction of models for water quality and quantity in the Imperial Valley.

\section{Salton Sea Study}

Plans to sample water in the Salton Sea are not being actively pursued at present. However, occasional grab samples in the Sea will be made to document baseline levels of major and trace constituents. Equipment is now being sought that will permit sampling at precise depths in the Sea. This would permit sea-water sampling along profile transects of the Sea at various longitudes and latitudes. Data are desired to understand better the salinity and temperature distributions in the Sea, as we11 as trace-element concentrations. Sediment sampling is seen as important to document baseline chemical speciation on the sea bottom near the mouths of the Alamo and New Rivers. We plan to acquire LANDSAT imagery to study circulation patterns and surface temperatures in the Sea.

\section{Chemical Support}

In this study, as in any waterquality study, chemistry of necessity plays an important role. To date we have had chemical analysis of our samples done both by groups at LLL and by commercial analytical laboratories in Southern California, both in and outside the Imperial Valley. Agreement among the results of the analyses by various laboratories thus far has been good, in general. To find one outside laboratory whose work we can trust, we are in the final stages (note: by the time the status report is published, we expect that these samples will have been shipped) of preparing a large group of samples to send to four laboratories: one in the Imperial Valley, two in the Los Angeles region, and one to our own chemistry group at LLL. Of the samples analyzed, $40 \%$ w 111 be for quality assurance, consisting of duplicates, splits, and standards - samples containing known mineral and trace elements. The standards were obtained from the 
U.S. Geological Survey Water Resources Division and the Environmental Protection Agency. Analysis of our samples by these four groups will provide not only valuable information of the chemical constituents of the water samples we have been taking, but also indications of the errors inherent in the analyses. We will then be in a position to assess the accuracy and precision of the results obtained by the various laboratories and to choose one to perform the buik of our subsequent work.

Since expanding the grab-sampling program from the Valley-wide and Salton Sea KGRA networks (Figs. 1 and 3), we will be collecting nearly 75 samples per month if our present sampling trips continue at the same frequency. Furthermore, we will be analyzing each sample for nearly 20 chemical species; that amounts to. 18,000 analyses in FY 77 alone. For this reason, we are pursuing alternate multielement techniques expected to be avallable for production work here at LLL. Among the most promis- ing of these is the neutron activation analysis system being developed for the National Uranium Resource Evaluation (NURE) Program. Other production-oriented methods within LLL are being investigated in an attempt to avoid the extremely high costs of wet-chemical analyses. In addition, refinement of the grabsampling networks will take place when sufficient data have accumulated to allow us to cut down the number of samples taken. Special investigations, using a recently purchased automatic stream sampler will allow us to take samples at closely spaced points in time. Thus, we can assess quantitatively the variation in water-stream quality and then determine proper grab-sampling intervals. A portable spectrophotometer has been purchased for the field determination of some specific chemicals. Additionally, current ion-specific-electrode technology is being reviewed to determine what may be appropriate for use in the Imperial Valley. 
Appendix A. Chemical Analysis of Typical Imperial Valley Water.

Table A-1. Irrigation water, Vail 4 canal, Gentry at Young Roads (T12SR13E-9R), sampled $2 / 25 / 76$ (LLL).

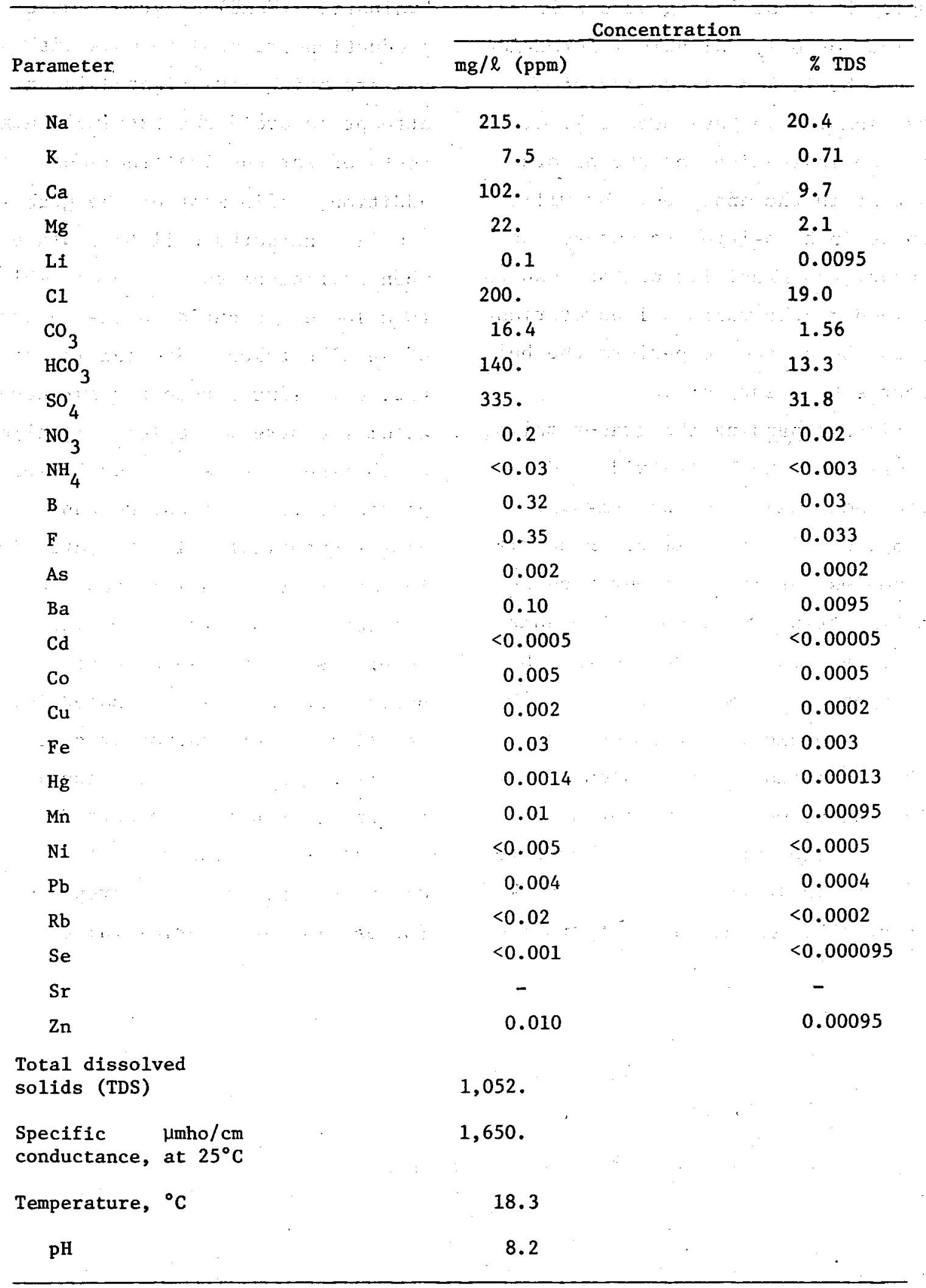


Table A-2. Drainwater, Va11 4 drain, Gentry at Foss Roads (T11SR13E-34N), sampled 2/25/76 (LLL).

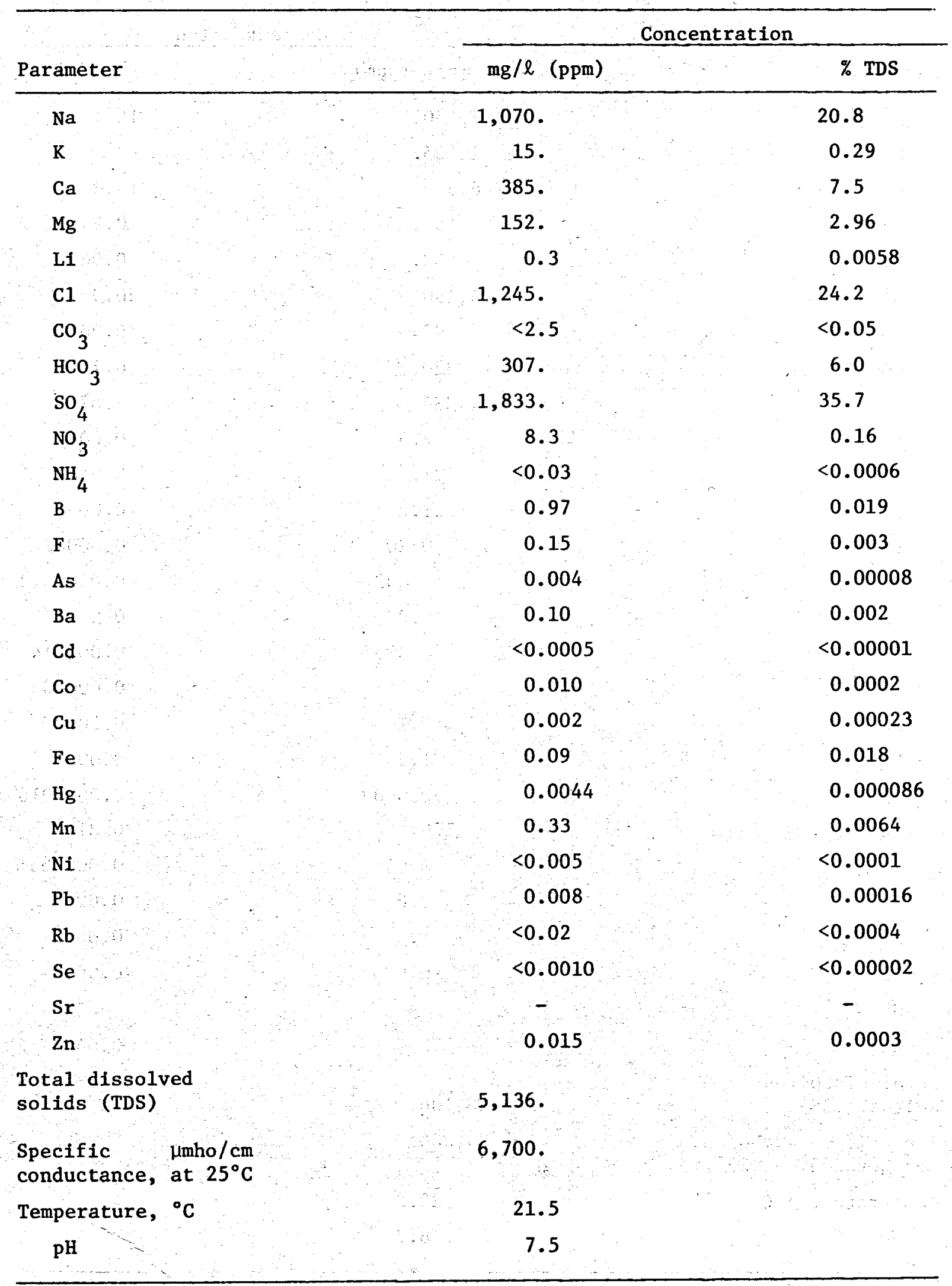


Table A-3. Drainwater, Sump 116, Boyle a t Kuns Roads (T12SR13E-4K), sampled $2 / 26 / 76$ (LLL).

\begin{tabular}{|c|c|c|c|}
\hline \multirow[b]{2}{*}{ Parameter } & \multicolumn{3}{|c|}{ Concentration } \\
\hline & & $\mathrm{mg} / \mathrm{l}$ (ppm) & $\%$ TDS \\
\hline $\mathrm{Na}$ & $\therefore$ & 7,250 & 15.1 \\
\hline $\mathrm{K}$ & & 1,305 & 2.7 \\
\hline $\mathrm{Ca}$ & & 6,855 & 14.3 \\
\hline Mg & & 450 & 0.94 \\
\hline $\mathrm{Li}$ & & 33 & 0.069 \\
\hline $\mathrm{C} 1$ & & 24,490 & 50.9 \\
\hline $\mathrm{CO}_{3}$ & & $<2.5$ & $<0.005$ \\
\hline $\mathrm{HCO}_{3}$ & & 350. & 0.73 \\
\hline $\mathrm{SO}_{4}$ & & 1,380 & 2.87 \\
\hline $\mathrm{NO}_{3}$ & & 2.9 & 0.006 \\
\hline $\mathrm{NH}_{4}$ & & 21 & 0.044 \\
\hline B & & 31.2 & 0.065 \\
\hline $\mathbf{F}$ & & 0.20 & 0.00042 \\
\hline As & & $<0.002$ & $<0.0000042$ \\
\hline $\mathrm{Ba}$ & & 1.2 & 0.0025 \\
\hline $\mathrm{Cd}$ & & 0.0065 & 0.000014 \\
\hline Co & & 0.04 & 0.000083 \\
\hline $\mathrm{Cu}$ & & 0.13 & 0.00027 \\
\hline $\mathrm{Fe}$ & & 1.35 & 0.0028 \\
\hline $\mathrm{Hg}$ & & 0.0008 & 0.0000016 \\
\hline$M n$ & & 100 & 0.21 \\
\hline $\mathbf{N i} \cdots$ & & 0.04 & 0.000083 \\
\hline $\mathrm{Pb}$ & Y.: & 0.82 & 0.0017 \\
\hline $\mathbf{R b}$ & & 1.3 & 0.0027 \\
\hline $\mathrm{Se}$ & & $<0.005$ & $<0.00001$ \\
\hline $\mathrm{Sr}$ & & - & - $\quad \cdots$ \\
\hline $\mathrm{Zn}$ & & 22.5 & 0.047 \\
\hline $\begin{array}{l}\text { Total dissolved } \\
\text { solids (TDS) }\end{array}$ & & 48,106 & $\cdots \quad$ \\
\hline $\begin{array}{ll}\text { Specific } & \mu \mathrm{mho} / \mathrm{cm} \\
\text { conductance, } & \text { at } 25^{\circ} \mathrm{c}\end{array}$ & & 75,000 & and \\
\hline Temperature, ${ }^{\circ} \mathrm{C}$ & & 22.2 & $\cdots, \cdots$ \\
\hline $\mathrm{pH}$ & & 6.7 & $\quad \because$ \\
\hline
\end{tabular}


Table A-4. Geothermal brine, Sinclair 4 wel1, Boyle at Lindsey Roads (T12SR13E-4Q), sampled $7 / 5 / 76.1$

\begin{tabular}{|c|c|c|}
\hline \multirow[b]{2}{*}{ Parameter } & \multicolumn{2}{|c|}{ Concentration } \\
\hline & $\mathrm{mg} / \mathrm{l}$ (ppm) & $\%$ TDS \\
\hline $\mathrm{Na}$ & 58,443 & 21.9 \\
\hline $\mathbf{K}$ & 14,918 & 5.60 \\
\hline$\therefore \quad \cdots$ & 26,992 & 10.1 \\
\hline $\mathrm{Mg}$ & 736. & 0.276 \\
\hline Li & 344. & 0.129 \\
\hline $\mathrm{C} 1$ & 154,590 & 58.0 \\
\hline $\mathrm{CO}_{3}$ & - & - \\
\hline $\mathrm{HCO}_{3}$ & 0. & 0 \\
\hline $\mathrm{SO}_{4}$ & 19. & 0.0071 \\
\hline $\mathrm{NO}_{3}$ & 5. & 0.0019 \\
\hline $\mathrm{NH}_{4}$ & 442. & 0.166 \\
\hline$\therefore$ & 332. & 0.125 \\
\hline $\mathbf{F}$ & 14. & 0.0053 \\
\hline As & 10. & 0.0038 \\
\hline $\mathrm{Ba}$ & 1,100 & 0.41 \\
\hline $\mathrm{Cd}$ & $<0.005$ & $<0.000002$ \\
\hline Co & $<0.0005$ & $<0.0000002$ \\
\hline $\mathrm{Cu}$ & 3. & 0.001 \\
\hline $\mathrm{Fe}$ & 1,340 & 0.503 \\
\hline $\mathrm{Hg}$ & $<0.2$ & 0.00008 \\
\hline $\mathrm{Mn}$ & 1,475 & 0.553 \\
\hline $\mathrm{Ni}$ & $<4$. & $<0.002$ \\
\hline $\mathrm{Pb}$ & 60. & 0.023 \\
\hline $\mathrm{Rb}$ & - & - \\
\hline $\mathrm{Se}$ & - & - \\
\hline $\mathrm{Sr}$ & 448. & 0.168 \\
\hline $\mathrm{Zn}$ & 600. & 0.26 \\
\hline $\begin{array}{l}\text { Total dissolved } \\
\text { solids (TDS) }\end{array}$ & 226,557 & 1 \\
\hline $\begin{array}{l}\text { Specific } \mu \mathrm{mho} / \mathrm{cm} \\
\text { conductance, at } 25^{\circ} \mathrm{C}\end{array}$ & - & \\
\hline Temperature ${ }^{\circ} \mathrm{C}$ & $>100$ & \\
\hline$\therefore \quad \therefore \quad \because$ & 5.3 & \\
\hline
\end{tabular}

1. Calif. Dept. of Water Resources, Bulletin 143-7 (1970). 
Table A-5. Seawater, Salton Sea, U.S. Navy Salton Sea Base (T11SR11E-21P), sampled $6 / 8 / 67.1$

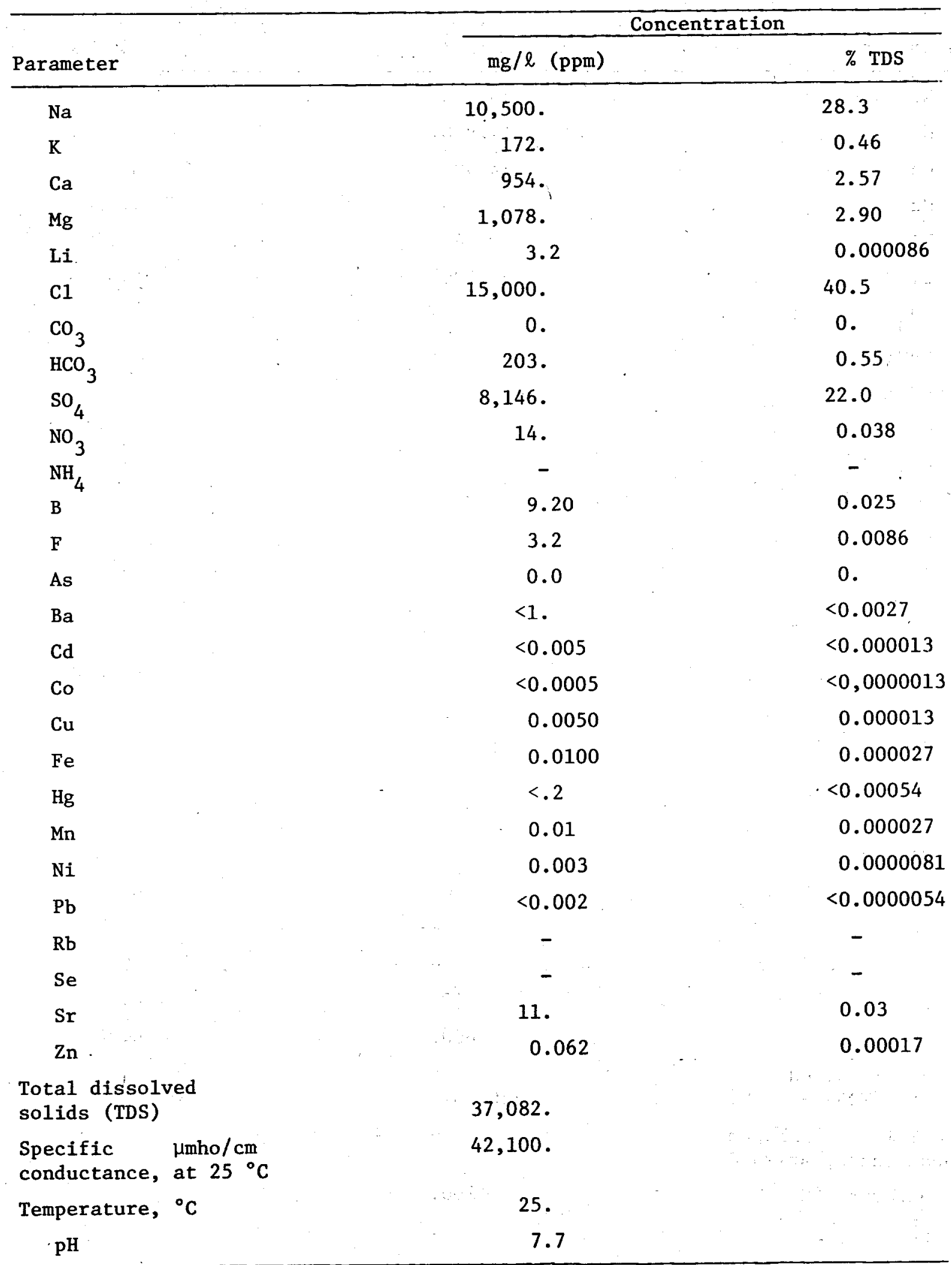

1. Calif. Dept. of Water Resources, Bulletin 143-7 (1970). 

ECOSYSTEM QUALITY

Joseph H. Shinn

The Ecosystem Quality group is organized into seven teams, each keyed to a specific task, but sharing personnel and facilities. Most teams are supported by one or more contracts.

\section{Site-Specific Baselines}

A sampling grid was established around the San Diego Gas and Electric site (SDG\&E) as shown on the map of Fig. 1. The LLL team collected soil and crop samples in January 1976 at the points marked (X). In February 1976 a team from the EPA Las Vegas Environmental Monitoring and Support Laboratory also established a grid and collected alfalfa (A), grasses (G), lettuce (L), and sugar beets (B), as well as soil samples at the points indicated in Fig. 1. The samples have not yet been ana1yzed completely. The LLL preliminary results show that the soils have a higher than expected content of $\mathrm{Ca}$, $\mathrm{Mg}, \mathrm{Br}, \mathrm{Mo}, \mathrm{Ni}, \mathrm{Zn}, \mathrm{Mn}$, and $\mathrm{Fe}$; but because of the alluvial history of the soils and the difficulty selecting suitable controls, interpretation of the results will take additional time. The LLL grid also included samples collected adjacent to the Southern California Edison site (SCE) at Sinclair No. 4 well (see Fig. 1). Further sample collection will be postponed until a decision is made by SCE to develop or abandon the site.

Shoreline Habitats

About 100 ducks (several species) and 20 geese (two species) were collected beginning October 1975 in cooperation with the U.S. Fish and Wildlife Service and the California Department of Fish and Game. We utilized vital organs from birds that were shot legally by hunters and from poached birds that were confiscated by law enforcement officers at the Wildife Refuges (see map, Fig. 2). About 10 other species of birds representing a cross-section of feeding types were collected as well; these included shorebirds and sparrow hawks. Rodents were collected in the vicinity of the SDG\&E site and the Wildlife Refuges. A contro1 population of waterfowl at the Sacramento National Wild1ife. Refuge was also sampled. After dissection, selected tissues were freeze-dried and stored. Elemental analyses by neutron activation analysis, $x$-ray fluorescence analysis, and atomic absorption spectrophotometry were undertaken on tissues from pintail ducks and snow geese to determine natural variability in the Imperial Valley population. In duck and goose livers the coefficients of variation $(s / \bar{x})$ were: 0.3 to 0.4 for $\mathrm{Fe}, \mathrm{Mn}, \mathrm{Ca}, \mathrm{Ni}$, and $\mathrm{Zn}$; 0.45 to 0.60 for $\mathrm{Cu}$ and $\mathrm{Br}$; and 0.7 


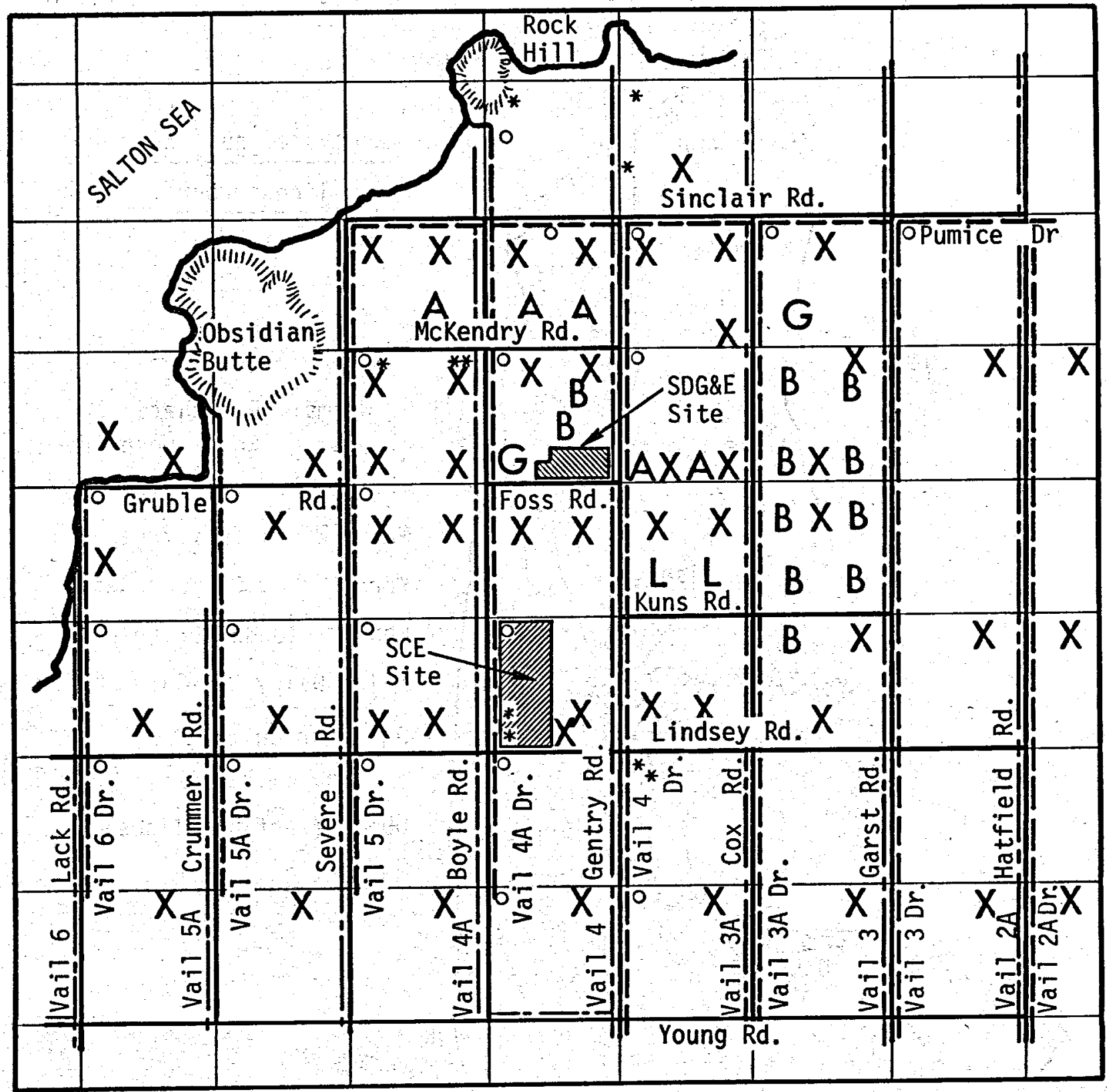

KEY

* Geothermal wells

- Sumps

$A, B, G, L$ EPA Monitoring and Support Lab. samples

$X$ LLL crop and soil samples

Fig. 1. Map showing locations where site-specific baseline samples were collected during FY 1976 in the Salton Sea Known Geothermal Resource Area. 


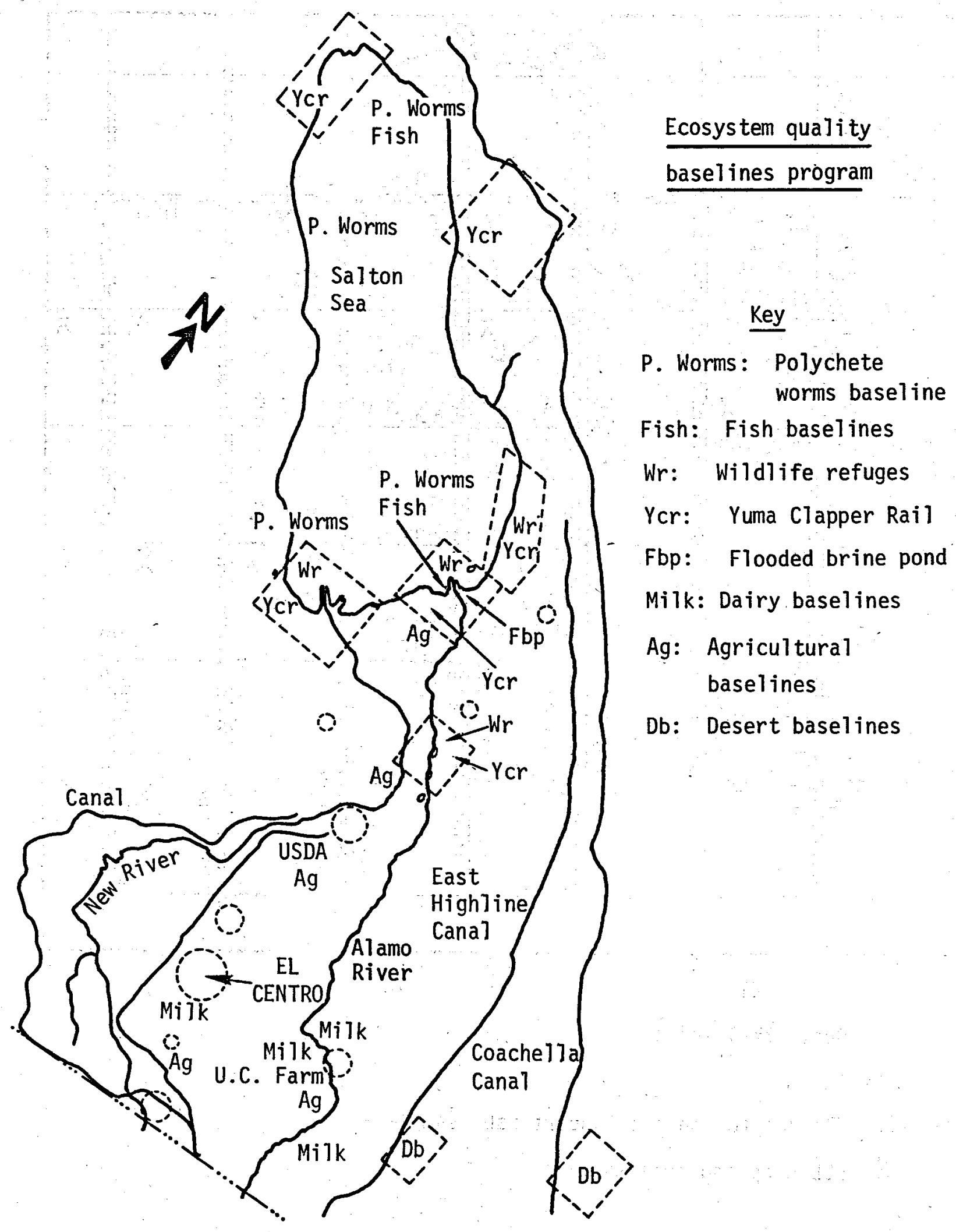

Fig. 2. Map showing locations throughout Imperial Valley where baseline studies are in progress. 
for Se. These variations are much greater than the errors of the analytical methods. It was decided that a second year collection of duck and geese samples should be made because of the variability in the populations and because of natural environmental differences from year to year. This study is continuing and interim reports will be issued in January 1977.

Elemental analysis on collected and preserved shorebird, hawk, and rodent tissue is also continuing; reports will also be issued in January 1977. The rate-1imiting step in these studies is the chemical analysis.

A contract was let to study the most important endangered species in the Valley. ("Ecology of the Yuma Clapper Rail in Imperial Valley, California," Arizona State University, Tempe, Arizona, Department of Zoology, Robert D. Ohmart, 1 June 1976 to 30 September 1977, $\$ 10,000$ ) Objectives are to determine total breeding population, monitor migratory arrival and departure dates, search for wintering population in the Imperial Valley, map and describe habitat, determine feeding habits, determine chronology of the reproductive cycle, determine mortality factors, determine effects of the rising Salton Sea and of geothermal development, and devise a Clapper Rail management plan.

Another contract was let for the study of nolse and habitat intrusion effects. ("Noise/Construction Effects of Geothermal Development on Wildlife Refuge Usage," st. Mary's College of California, Moraga, California, Philip Leftner, 1 July 1976 to 1 July 1977 , $\$ 19,000$.$) The objectives are to deter-$ mine sound-pressure levels (SPL) of background activity and typical geothermal development activity of the 1iquid-dominated systems, to predict SPL that may occur at wildlife refuges, to estab1ish seasonal patterns of wildlife-refuge usage near KGRAs, determine case histories of wildlife response to noise and disturbance effects including power-line effects, and to recommend mitigation measures as necessary.

\section{Aquatic Studies}

The aquatic team is subdivided into Salton Sea-fishes study and Pileworm and freshwater studies.

\section{Salton Sea Fishes}

Early plankton tows and assays were completed, and preliminary Salton Sea-fish collections were made by an LLL team. Contract assistance for this was planned for June, but the contract was actually awarded in September; detalls are given later. Baseline fish samples were collected in mid-April and mid-July (see map, Fig. 2), using a 150-ft, standard, graded gill net. About 20 fish of each of the 3 major species in a 
range of sizes were collected each time. Morphometric measurements made were weight, standard length, age (based upon otolith annulation plus annulation on vertebral centra), and fin-ray counts. (The asymmetry of fin-rays is a standard indication of stress.) Tissues preserved for analyses were muscle, gill, bone, kidney, liver, gut contents, skin, and remains. Beach seines were used to collect mollies for similar morphometric analyses near the mouths of freshwater streams.

Ecological studies showed that there are frequent die-offs resulting. from unknown reasons, but at least one kill (21 April) near the Alamo River mouth was apparently a result of Salton Sea flooding and washingout of adjacent, old geothermal-brine ponds (see map, Fig. 2). Population dynamics estimated from die-offs show a ratio of $100: 1$ of both croaker to corvina (predator) and croaker to threadfin shad in the 3- to 5-in. class. The ratio of croaker to sargo was about $300: 1$. Attempts to locate and collect eggs and larvae of corvina were unsuccessful although it is known that spawning occurred in August. Bioassays to determine toxicity of geothermal brine to croaker larvae showed that the median lethal level (TLM) was $36 \mathrm{hr}$ with 500-ppm geothermal brine (from the Magmamax-1 well at the SDG\&E site) in Salton Sea water and 24 hr with 5000-ppm geothermal brine in Salton Sea water, while the normal TLM was $72 \mathrm{hr}$. Adult fish (mostly croaker) have been captured and transplanted into the LLL 2000-gal circulating Salton Sea-water system for further studies.

Elemental analyses have not been completed on preserved baseline fish tissue. Elements of particular interest because of a high concentration in geothermal brines compared to sea water are Mn, $\mathrm{Zn}, \mathrm{Fe}, \mathrm{Li}, \mathrm{Cd}, \mathrm{Ba}, \mathrm{Se}$, $\mathrm{Cu}$, and $\mathrm{Rb}$.

A contract was awarded to determine toxicity and assist in interpretation of baseline collections. ("Salton Sea Fishes - Baseline Study and Corvina Toxicity Study," California State University at Hayward, Department of Biological Sciences, Richard E. Tullis, 1 October 1976 to 30 September 1977, $\$ 26,000$.$) Objectives$ are to collect and prepare fish tissues from major and minor Salton Sea-fish species for baseline traceelement analyses, indices of fish stress, and biomass and spawning estimates for corvina, and to determine sensitivity of major fishes to geothermal brines and existing stress.

A contract was also awarded for assistance in sampling. ("Salton Sea Sampling Program," California Department of Fish and Game, Robert Hulquist, Fisheries Biologist, 1 October 1976 to 30 September 1977, 
\$4600.) Personnel will be provided to sample fish, to maintain sampling gear, and to prepare and ship fish samples to LLL.

\section{Pileworm and Freshwater Studies}

The polychete worm Neanthes, commonly called the pileworm, is a sediment dweller and detritus converter that is a food for every major fish in the Salton Sea. The pileworm is important as a bioassay organism for toxicological effects of geothermal brines as well as a key organism for determining baseline transfer rates of metals from contaminated river-borne sediments into the marinefood chain. Pileworms were collected beginning in February 1976 at the four sites around the Salton Sea (see Fig. 2). A site near the discharge point of agricultural drains from the SDG\&E and SCE sites was included (Fig. 1). Collections were required again in March, April, June, July, August, and October because of sampling and culturing problems. Sampling will continue on a quarterly basis. Initial elemental analyses were performed by neutron activation analysis, $x$-ray fluorescence, and atomic absorption spectrophotometry to determine baseline levels of elemental composition af ter the worms had expelled all sediment from their digestive tract. A study was made of retention of key elements by captured worms. Both the chemical analyses and interpretation of these data will take more time. A bioassay study of $\mathrm{Zn}$ toxicity and retention was performed on captured worms. With a background of $0.1 \mathrm{ppm} \mathrm{Zn}$, the addition of $50 \mathrm{ppm} \mathrm{Zn}$ to sea water caused the worms to retain as much as $5 \mathrm{ppm}$ for longer than 21 days. The time to $100 \%$ lethality (TL) for these pileworms was 0.5 days at $50 \mathrm{ppm} \mathrm{Zn}, 4.8$ days at $20 \mathrm{ppm} \mathrm{Zn}$, and 12 days at 10 ppm Zn. These data are relevant to SDG\&E plans to discharge $\mathrm{Zn}$-contaminated cooling water. Unanswered questions about $\mathrm{Zn}$ retention and osmotic regulation will be examined. ("Pileworm Larval Success at Higher Salton Sea Salinities," Department of Zoology, Pomona College, California, Larry C. Oglesby, 1 July 1976 to 30 September $1977, \$ 10,000$.$) The objectives are$ to determine salinity effects (possibly resulting from geothermal development) on egg and larva from acclimated adults, to determine survival of planktonic larva and adults in the Salton Sea compared to Pacific Ocean contro1 populations, and to determine the effects of seasonal temperature changes on the above.

A freshwater studies program was initiated after the April IVEP Advisory Panel Review indicated that economically important populations of fish in agricultural drains had been overlooked. We are cooperating with the Colorado River Regional Water 
Quality Control Board (WQCB) and plan to do baseline elemental-analysis studies and to do bioassays with geothermal brine on Gambusia affinis (mosquitofish), both at LLL and with contract assistance. ("Bioassay Procedures to Evaluate Acute Toxicity of Salinity and Geothermal Pollutants to Gambusia affinis," North Carolina Central University, Durham, North Carolina, William L. Mills, 1 October 1976 to 30 September $1977, \$ 10,000$. The objectives are to develop a series of static bioassay tests to determine salinity tolerance and acute toxicity of geothermal brine to juvenile and adu1t mosquitofish that are native to Imperial Valley, to conduct experiments to determine the synergistic effect on toxicity of population levels, to determine the acute toxicity of several metals that are components of geothermal brine (Fe, Mn, $\mathrm{Zn}$, and $\mathrm{Cu}$ ), and to identify synergistic or antagonistic effects. Agriculture

Four Imperial Valley dairies (see map, Fig. 2) are sampled regularly and the milk is analyzed for contaminnant trace elements. A number of control samples are obtained from the nation-wide EPA milk network. A Valley-wide collection system has recently been established for lettuce, sugar beets, melon, and alfalfa with the aid of contract labor from the University of California, Agricultural
Extension Service. (1 October 1976 to 30 September $1977, \$ 10,000$.$) This$ network will consist of collection points at each of the four major KGRAs, at the U.S. Department of Agriculture (USDA) and the University of California experimental farms, and at farms throughout the Imperial Valley where local growers' organizations periodically conduct experiments (see map, Fig. 2). By cooperating with existing projects, we obtain more accurate records of treatment, such as historical data on fertilization, irrigation, planting, etc., that are important for interpretation of observed elemental compositions. Contract support has been obtained to determine "Solute Movement in Soils Following Brine Spil1s." (Department of Soil Science and Agricultural Engineering, University of California, Riverside, W. A. Jury, 1 July 1976 to 30 September 1977, $\$ 15,000$.$) The$ objective is to predict the longterm effects of a geothermal brine deposit on the soil surface in terms of its movement through the soil and eventual appearance in groundwaters. or artificial drains. A contract has also been awarded to determine "Trace, Metal Speciation in Saline Waters. Affected by Geothermal Brines." (Kearney Foundation of Soil Science, University of California, Riverside, Garrison Sposito, $\$ 15,000$.$) The$ objectives are to calculate the 
trace-metal chemical equilibria for cases of geothermal-brine intrusion into waters and soils of the Imperial Valley.

\section{Desert Habitats}

The baseline studies in the Imperial Valley deserts adjacent to KGRAs are being performed by a team from the University of California at Los Angeles (UCLA) Laboratory for Nuclear Medicine and Radiation Biology under the general supervision of Dr. Evan Romney. Vegetation, soil, and mammals were collected in three field sorties from February to April 1976 in the Dunes KGRA and near geothermal we11s in the East Mesa KGRA (see map, Fig. 2). At East Mesa, Wells 5-1, 6-2, 8-1, and $31-1$ were collection points. A dimensional analysis of diversity. in vegetation spectes, ground cover, and biomass was completed for both KGRAs. Soll microarthropods were studied in March, July, and August 1976 by the UCLA group. Samples of Insects and soil were collected by day and night. Few microarthropods were found except near citrus groves adjacent to We11 31-1. Chemical analyses (especially $\mathrm{Na}, \mathrm{Cl}$, and $\mathrm{Mg}$ ) have been performed on all insects and soil samples near the site where We11 $31-1$ was vented in the past. Preliminary studies of salinity effects on soil arthropods have been conducted. A beetle Eleodes has been selected for bioassay studies, beginning with field studies on population dynamics, larval development, feeding mechanisms, and the amounts and nature of food. The bioassays will determine the responses of beetle-1arva populations to geothermal-induced salinity changes. A mammal study was initiated, and baselines of elemental burdens in vital organs (muscle, hide, stomach/ colon) of kangaroo rats are in progress. A bird study has been started with vegetation/habitat mapping using aerial photographs and the assistance of William Rhoads of EG\&G.

Consumptive Water Use

A project was initiated to determine the actual water requirements of crop plants in preparation for more intensive management of consumptive water use. (A "Regional Crop WaterUse Bulletin" is being prepared under a contract to the Department of Water Science and Engineering, University of California at Davis, William 0. Pruitt, 1 July 1976 to 30 December $1976, \$ 3200$.) The objectives are to utilize existing California crop evapotranspiration rates and state-of-the-art methods to estimate Imperial Valley water use. (Specific "Imperial Valley Evapotranspiration and Crop Ecology Studies" are being provided under a memorandum of agreement with USDA Imperial Valley Conservation Research Center, Brawley, 
California, Bur1 Meek, 1 July 1976 to 30 September 1977, $\$ 10,000$.$) The$ objectives are to measure evapotranspiration of crops using unique facilities at the Center - a $3 \mathrm{~m} \times 3 \mathrm{~m}$ weighing lysimeter and a micrometeorological, Bowen-Ratio System - and to obtain crop water-use rates for critical periods (e.g. heat advection from the dry desert) when standard methods grossly underestimate evaporation rates. The Center also provides services to other Ecosystem Quality Teams under the terms of the agreement (see map, Fig. 2). The LLL Team conducted its own micrometeorologica1 evapotranspiration measurements to augment the Bowen-Ratio measurements, to standardize the different methods of measurement, and to explore the effects of heat advection on evapotranspiration from alfalfa. This experiment is complete and the data are being processed.

\section{Air Pollution Effects}

Short-term exposures of lettuce and sugar beet plants to a facsimile geothermal air pollutant were carried out by the LLL team at the Imperial Valley Conservation Research Center (see map, Fig. 2) using an array of circular, open-top chambers $3 \mathrm{~m}$ in diameter and $1.22 \mathrm{~m}$ high, as shown in Fig. 3. The exposures of 3-hr duration were intended to simulate geothermal power plant plumes, and the gas mixture $\left(15 \mathrm{CO}_{2}: 1 \mathrm{H}_{2} \mathrm{~S}: 1 \mathrm{CH}_{4}\right.$ : $2 \mathrm{~N}_{2}$ parts by volume added to air) had a stimulatory effect on lettuce photosynthesis at low concentration (less than $15 \mathrm{ppm} \mathrm{CO}_{2}$ and $1 \mathrm{ppm} \mathrm{H}_{2} \mathrm{~S}$, etc.) and a depressing effect at higher concentrations (greater than $75 \mathrm{ppm}$ $\mathrm{CO}_{2}$ and 5 ppm $\mathrm{H}_{2} \mathrm{~S}$, etc.). ${ }^{1}$ These experiments will be carried out with other crops and the synergism with existing Imperial Valley air pollution (ozone) will also be explored. (A contract to study "Synergistic Effects of $\mathrm{H}_{2} \mathrm{~S}, \mathrm{CO}_{2}$ and $\mathrm{O}_{3}$ on Vegetable Crop Yields" was awarded to Department of Vegetable Crops, University of California, Davis, James P. Bennett, 1 October 1976 to 1 October 1977, $\$ 10,000$.$) The objectives are to deter-$ mine the susceptibility of tomato, onion, and bean plants in a joint experiment with LLL, using controlled fumigations of the geotherma1facsimile gases in situ. (Chronic exposure of alfalfa, lettuce, sugar beets, and cotton to $\mathrm{CO}_{2}-\mathrm{H}_{2} \mathrm{~S}$ mixtures is being performed in "Supplemental Studies of Air Pollution Effects for Imperial Valley Environmental Programs," Statewide Air Pollution

1. J. H. Shinn, B. R. Clegg, M. L. Stuart, and S. E. Thompson, "Exposures of Field-Grown Lettuce to Geothermal Air Pollution - Photosynthetic and Stomatal Responses," J. Environ. Sci. Health All, 603 (1976). 


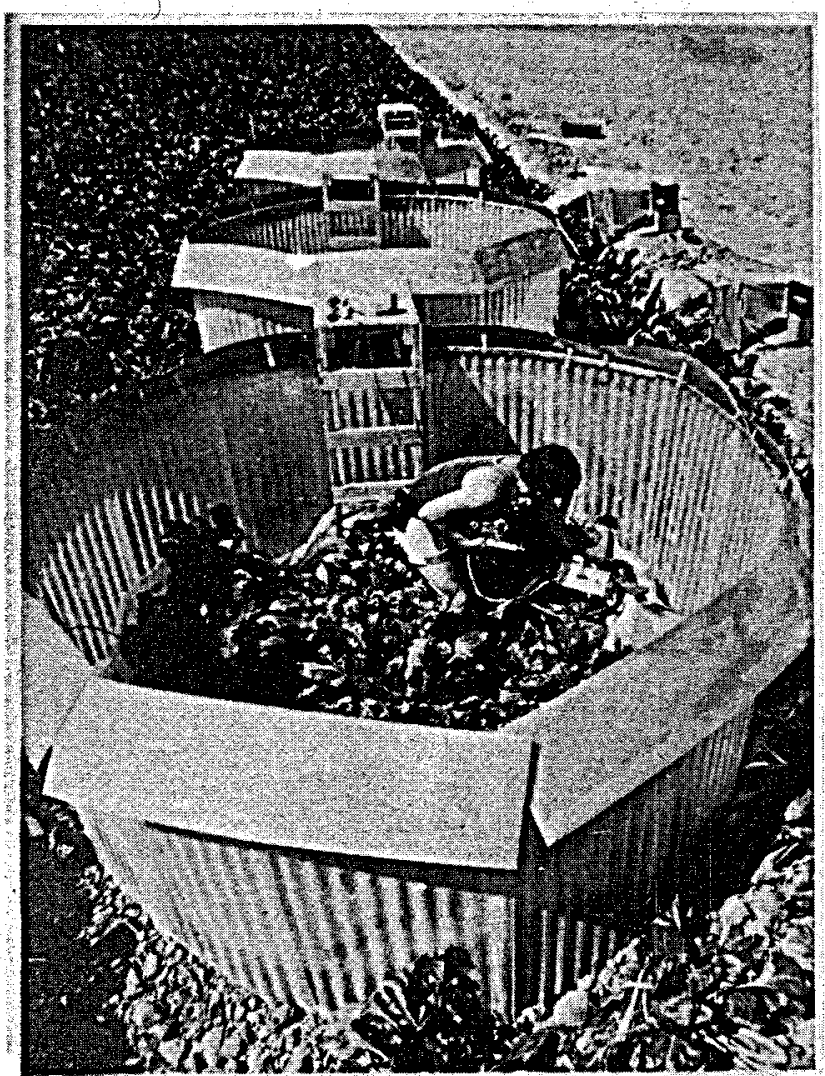

Fig. 3. Field-fumigation experiments at the U.S. Department of Agriculture Field Station near Brawley, California. Plants receive shortterm exposures to a gas mixture simulating the noncondensable gases to be released by geothermal power plants. Transpiration and photosynthetic rates are measured during the exposure period.

Research Center, RIverside, California, C. Ray Thompson, 1 July 1976 to 30 September 1977, \$10,000.) The objectives are to determine the changes in crop visual symptoms, height, and biomass production under controlled, chronic exposures in greenhouses. (A contract was awarded to study the "Mortality and Life-Span of Honeybees Exposed to Hydrogen Sulfide Gas," Department of Entomology, University of California, Riverside, E. Laurence Atkins, 1 July 1976 to 1 October $1977, \$ 5,000$ ) The objectives are to use proven bioassay methods to determine whether these economically important pollinator insects are susceptible to geothermal air pollutants.

Characteristics of the deposition rates of geothermal gases have been inferred for lettuce and alfalfa through measurements of the rate of exchange of other gases $\left(\mathrm{CO}_{2}, \mathrm{H}_{2} \mathrm{O}\right)$ in crop fields. These data are being analyzed and the measurements are continuing periodically during the winter growing season. It is expected that the deposition of air pollutants will vary by more than 100 -fold because of biological rate-limiting factors.

\section{Summary Note}

All of the teams reporting progress here will be participating in a 3-day workshop, 8-11 November 1976; involving the LLL teams, the 14 contractors, the UCLA team, and guests such as representatives of SDG\&E, SCE, U.S. Fish and Wildlife Service, and ERDA. The purpose of this workshop will be to produce a comprehensive, integrated report on the Ecosystem Quality SubProgram. 
IMPERIAL VALLEY ENVIRONMENTAL PROJECT

Subsidence and Seismicity

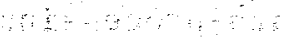

$+1$

and

and

ardentan 
SUBSIDENCE AND SEISMICITY

Neil B. Crow

Introduction

Any significant subsidence or seismic activity that might be induced by geothermal activity, primarily the production and reinjection into the formation of geothermal brines, would engender serious environmental concern in the Imperial Valley community. The detection of such earth movements in the presence of a high level of naturally occurring ground surface subsidence and a degree of earthquake activity among the highest in the United States requires careful documentation of the present levels of activity and monitoring of any incremental movements. The program we have established to accomplish these results is given in the following outline and discussed in more detail in the following sections.

Our studies in this section have involved extensive cooperation with other agencies - Federal, State, and local. Our major accomplishments include the encouragement of a resurvey of the Imperial Valley Subsidence Detection Network by an interagency group, and a contract with the California Division of $0 i 1$ and Gas, which manages the resurvey, to contribute $\$ 35,000$ toward the cost of the work. We have also established a local subsidence-detection network in the Salton Sea geothermal field area, centered on the SDG\&E/ERDA Geotherma1 Test Facility. This work was done under contract to LLL by the Imperial County Department of Public Works; the total amount was approximately $\$ 10,500$.

To obtain detailed seismic coverage in the Salton Sea area and to obtain uniform coverage in the Valleywide network of seismometers, we have contracted with the U.S. Geological Survey (USGS) to insta11 six seismometer stations in the Salton Sea area. These units will be tied into the USGS regional network of seismometers. Data from these seismometers will be telemetered to the USGS regional data-processing center and analyzed data supplied to LLL. Our cost for installation and the first year of operation is approximately $\$ 60,000$. Installation of the seismographs is now complete and telemetering is being established.

Summary of Progress on Project Tasks

\section{Subsidence}

Valley-wide subsidence-detection network - Milestone: Complete 2/78 Accomplishments: Contract for $\$ 35,000$ let to California Division of Oil and Gas for partial support of resurvey of the interagency Imperial Valley Subsidence Detection Network. LLL was instrumental in encouraging resurvey of this network, which is to be done this winter (1976-77). Field 
work should be completed by early spring 1977, and data reduced by the end of CY 1977.

Site-specific subsidence-detection networks - Milestone: Complete 2/78 Accomplishments: Established subsidence-detection network in the Salton Sea Geothermal Field area, centering on the SDG\&E/ERDA Geothermal Test Facility. Networks for other geothermal areas at North Brawley and Heber are currently being designed.

Horizontal motion-detection network - Funds were not available in spring 1976. Now preparing to negotiate with potential contractors for work to improve existing nets.

Subsidence-detection equipment Study of this type of equipment under way. Funds have not been available during FY 76. Will negotiate for extensometer at North Brawley during FY 77.

Data analysis - Second-order surface elevations from subsidiary network have been obtained for the 197172 and $1973-74$ surveys and used to analyze localized surface movements. When both first- and second-order data from 1976-77 survey become available it will be used to interpret land-surface movements.

Subsidence modeling - Program plan In preparation. Program to be operational $9 / 77$.

\section{Seismicity}

Seismographic networks (including data analysis) - Accomplishments: Under an LLL contract for $\$ 69,000$, the U.S. Geological survey is installing 6 seismometers in the area of the Salton Sea geothermal fleld that are to be connected to the USGS regional telemetered network. The contract also includes the first year of operation. The field installation was completed in October 1976 and presently telemetering connections are being made. Data will be available by winter 1576-77.

Selsmic study of the Imperial Valley - Program plan is being developed. One product of study will be the creation of a new seismicvelocity model of the Imperial Valley, essential to more accurate determination of the location of earthquake hypocenters (foci), that will be essential in distinguishing naturally occurring earthquakes from any that might result from geothermal activity. Ground-Movement Studies

Valley-Wide Subsidence Detection

The possibility of subsidence induced by geothermal activity was recognized early in the $70^{\prime} \mathrm{s}$ as a potential problem to the irrigated agriculture in the Imperial Valley. Local authorities, primarily the Imperial County Department of Public 
Works and the Imperial Irrigation District, were concerned with the possible impact of subsidence on the irrigation and drainage systems of the Valley. They were joined by the California Division of $0 i 1$ and Gas, which regulates geothermal wells, and the U.S. Geological Survey Subsidence Research office, located in Sacramento. This group of agencies was instrumental in establishing a network of precisely surveyed landsurface elevations in the Imperial Valley. The work was done by an inter-agency committee, the Imperial Valley Subsidence Detection Committee (IVSDC), composed of these and other agencies with an interest in the subject. The network was established in the winter of 1970-71; it consists of first- and second-order leveling as shown in Fig. 1. The order of leveling is an indication of its precision: first-order leveling is highly precise and correspondingly expensive; only a few survey crews, primarily those of the National Geodetic Survey (NGS), are capable of attaining the required precision, Second-order leveling is slightly less precise, but still of high quality. In the Imperial Valley, crews of the Imperial County Department of Public Works and the Imperial Irrigation District are capable of such work. In the establishment of the survey, the first-order work was done by NGS crews, and the local agency crews were joined by State and Federal agency crews capable of second-order work. The NGS survey linked the first-order part of the network to the national first-order leveling network, thus tying the Imperial Valley network to sea-level elevations at San Diego.

During the winter of 1973-74, the IVSDC sponsored the first resurvey of the Imperial Valley level network. The results of this resurvey made possible the determination of the changes in surface elevation that occurred during the period between the two surveys. Substantial surfaceelevation changes had occurred in the 2-year period between surveys. Lofgren of the USGS Subsidence Research office published a paper in 1974 reporting the results of the first-order leveling; ${ }^{1}$ subsidence of as much as $13 \mathrm{~cm}$ had taken place, primarily in the north end of the Imperial Valley near the Salton Sea (Fig. 1). This subsidence, at the rate of over $5 \mathrm{~cm} / \mathrm{yr}$, occurred in the virtual absence of any geothermal production. It is imperative to document such substantial naturallyoccurring regional movement as a baseline so that any possible incremental movement resulting from geothermal development can be detected. One of the early objectives of the IVEP has been to arrange another resurvey of the precision-leveling 


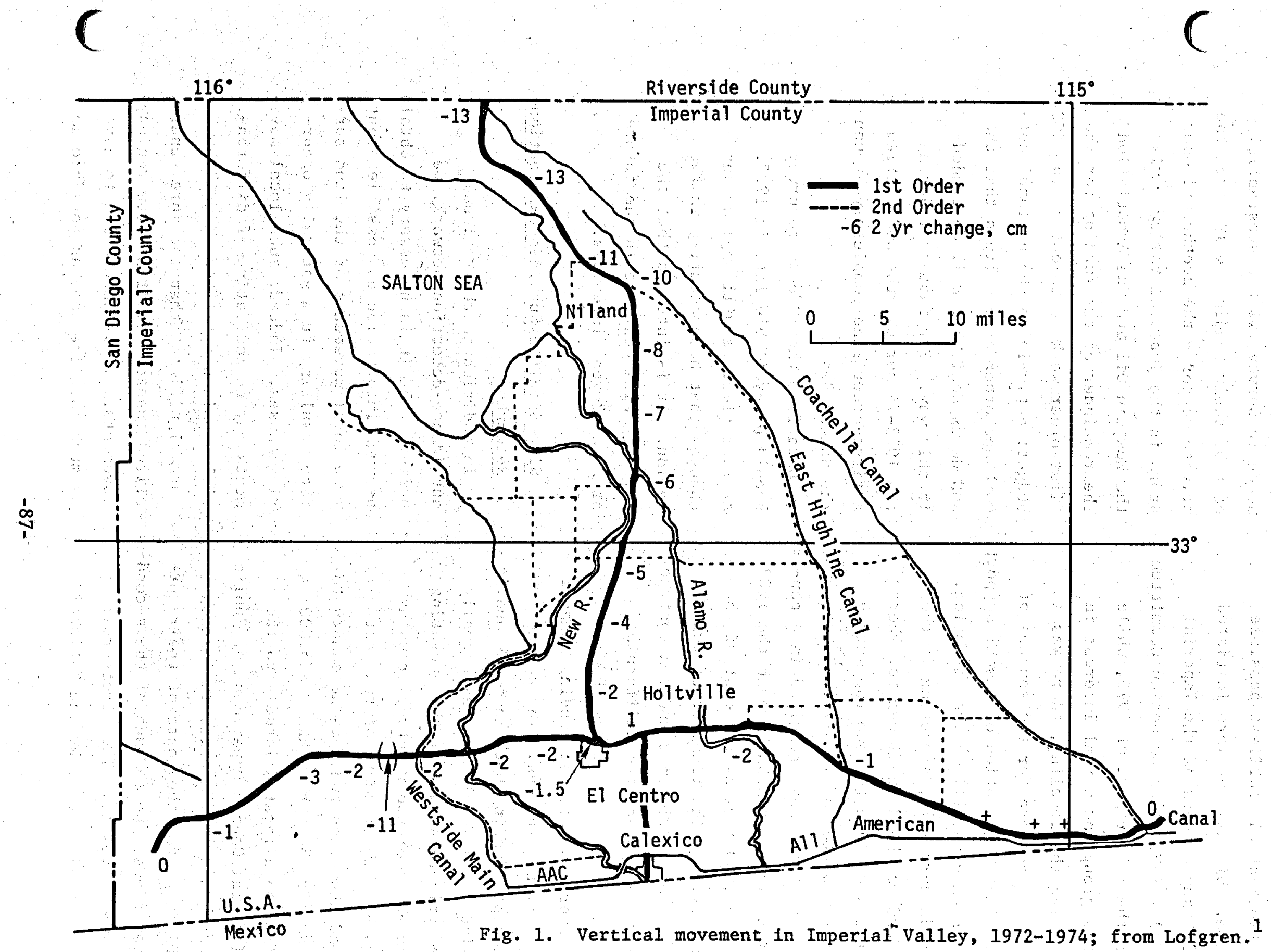


network at the earliest possible time. Discussions were initiated with key members of the Imperial Valley Subsidence Detection Committee in the latter part of 1975; while this group had a rea1 interest in redoing the leveling, there was a serious concern for the sources of funding. Indication of fiscal support by ERDA crystallized the situation. In January 1976, a meeting of the IVSDC was held in E1 Centro, where it was decided to redo the survey in the winter of $1976-77$. Subsequent negotiations have resulted in a contribution from ERDA through the IVEP of $\$ 35,000$ towards the cost of the surveying. The transfer of funds has been carried out under a contract between LLL and the California Division of Oil and Gas (DOG). The latter has acted as funding manager of all the surveys. The agency accepts funding both in money and in kind - the local agencies normally contribute a part of the operating expenses of their survey crews as much of their share of the cost and disburses funds as necessary to pay for the work. LLL's $\$ 35,000$ will be allocated largely to the Imperial County Department of Public Works and the Imperial Irrigation District for the costs of their survey crews, who do much of the secondorder leveling. The first-order work will be done by the National
Geodetic Survey, with a substantial part of their funding coming from the private sector - the geothermal oper-i ators in the Imperial Valley - via the Western 0il and Gas Association. The remainder of the funding for the first-order work comes out of the NGS budget; a tie-in to the national network and other survey lines that the NGS deems desirable will be funded in this way. For instance, during the 1973-74 survey, the NGS carried a first-order line completely around the Salton Sea.

Data from the 1976-77 resurvey should be available late in 1977. At that time, we will analyze any changes that have occurred in the region. It is intended that the leveling will continue in the future at 2- or 3-year intervals.

\section{Site-Specific Subsidence-Detection}

\section{Networks}

In addition to the regional

subsidence-detection network, we believe that it is necessary to obtain as much information as possible about more local movements of the land surface resulting from naturally occurring causes. Indeed, such local movements may be indicative of differential subsidence that could well be more significant than the more generalized changes resulting from regional movements. It is imperative to have as much baseline data as possible to 
establish a level of activity upon which any subsidence induced by geothermal activity - primarily production and injection of geothermal fluids - would be superimposed.

Some data about local movements already exist; as part of the conditions for a geothermal development: permit, Imperial County requires the operators of geothermal wells to survey a vertical elevation tieline to the nearest part of the Va1ley-wide subsidence detection network. These data are on file in the County Department of Public Works and are public information.

We are supplementing these well ties by localized subsidence-detection networks. The first of these to be established is in the Salton Sea geothermal field area and is centered on the SDG\&E/ERDA Geotherma1 Test Facility. This network is shown in Fig. 2 . It is designed to create a crossconnected mesh so that any local surface-elevation change can be characterized accurately. We intend to resurvey the network again this winter in conjunction with the resurvey of the Valley-wide network. This will provide the first opportunity to detect local surface-elevation changes with this network.

We will establish similar networks at both the North Brawley and Heber Geothermal Fields. It will be necessary to coordinate our efforts with those of other agencies and the geothermal operators; because development is currently proceeding in both areas, it may be possible to maximize the usefulness of the well tie-ins to determine local surface-elevation changes. Design of networks for these areas is currently underway.

Surface-elevation surveys at the East Mesa Geothermal Field have been carried out by the Bureau of Reclamation, which operates geothermal wells in that area. The Bureau is a member of the IVSDC, and their data are coordinated with the Valleywide survey Information from their surveys is public record.

\section{Horizonta1 Motion-Detection}

Network

The Imperial Valley is a tectonically active area, bounded on the east and west by major active faults that are part of the San Andreas: fault system of Southern and Central California. The major sense of motion on the San Andreas fault system in the Imperial Valley is right-1ateral strike-slip faulting; in other words, the block to the west of a fault moves northwestward relative to the block on the east of the fault. Additionally, in the Imperial Valley there is significant vertical movement on the faults that is not characteristic of the regions more northwesterly along the system. While any vertical movement will be monitored by the 


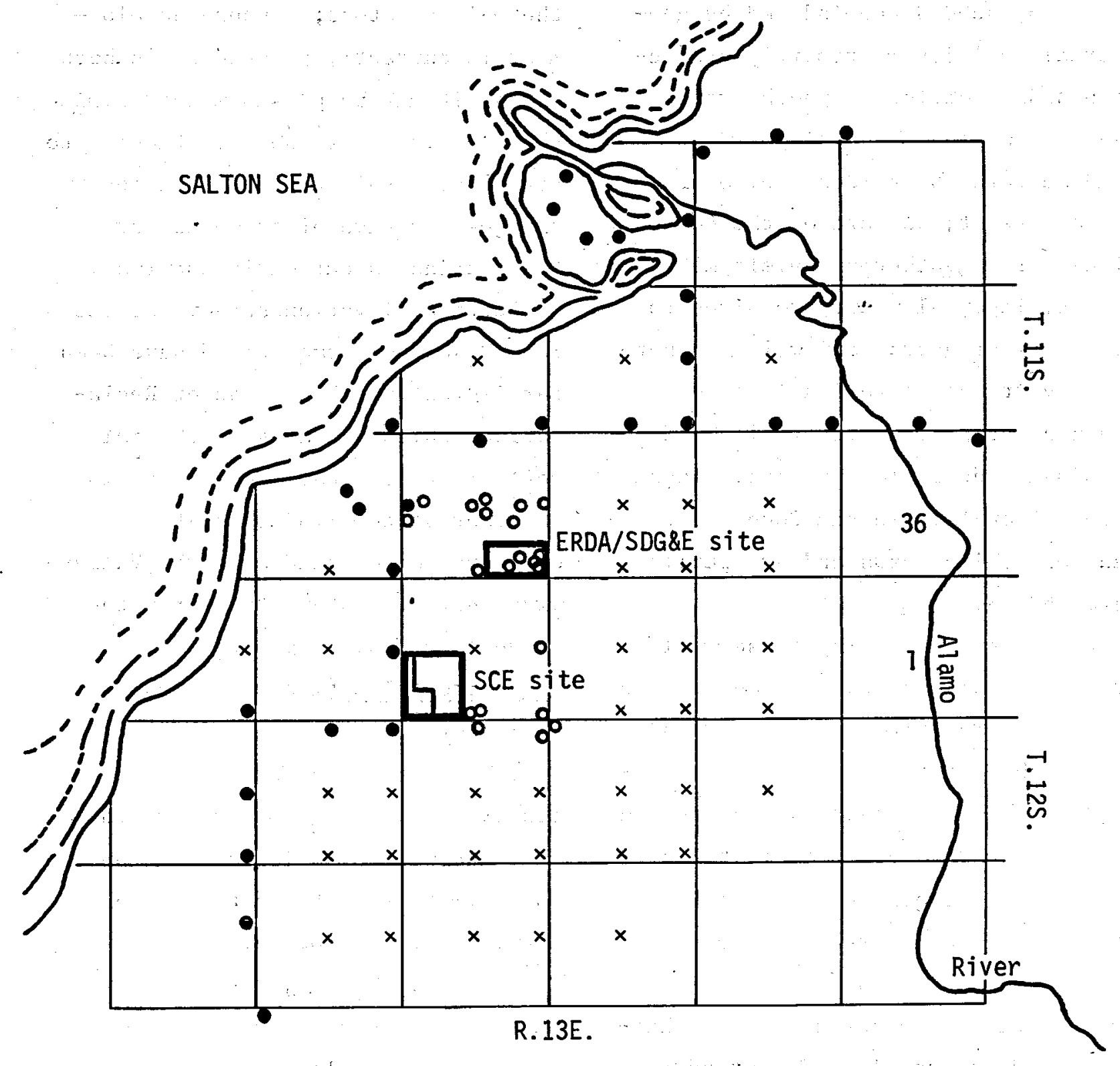

- Approximate location of Imperial county first- and second-order bench marks. - Approximate location of company second-order bench marks.

$x$ Approximate location of additional ERDA/LLL second-bench marks.

Fig. 2. Local leveling network near ERDA/SDG\&E and SCE sites. 
subsidence Detection Network, it is important to obtain data about the amount of lateral surface movement on the floor of the Imperial Valley. To this end, two programs are being carried out.

\section{Large-Scale Trilateration Network}

The Imperial Valley is partially covered by a large-scale trilateration network maintained by the crustal Strain Group of the USGS (Fig. 3). The primary purpose of the network is to detect horizontal movement of the land surface in the vicinity of the San Andreas Fault zone of Southern and Central California. Trilateration is based on the use of laser-based distance-measuring equipment. These instruments are extremely accurate, and geodetic surveying has been revolutionized by their use. Trilateration is quite inexpensive and rapid compared to the previously employed triangulation method, which depends on the use of theodolites to measure angles over long distances. Because of the low expense and high accuracy of the trilateration process, we have discussed with the Crustal Strain Group the possibility of extending their trilateration network south and east to cover the remainder of the Imperial Valley. Unfortunately, the Crustal Strain Group was unable to participate in this effort, primarily because of logistic difficu1ties - the flat terrain of the Valley does not have the hills necessary to set up their equipment at heights sufficient to permit large-scale surveying. There are two methods of obtaining accurate horizontal control in the Valley: to connect the existing small-scale trilateration networks, discussed in the following section, by traverses to give the necessary coverage; and to repeat the work of R. Mason of the Imperial College of London. Dr. Mason has worked on a traverse across the Imperial Valley from east to west that gives some quantitative estimates of the horizontal motion along several of the faults that traverse the Imperial Valley. We will request a proposal from the USGS Subsidence Research office to perform the traverses between the local networks, and Dr. Mason is to submit an informal proposal in the near future, describing his work and the cost of repeating it. We will choose the most cost-effective combination to obtain the coverage we require.

Sma11-Scale Horizontal Motion

Detection Networks

Because local movements along a fault zone are fully as important as large-scale movements, sma1ler-scale horizontal-control networks have been established at the geothermal fields; this work has been done by the USGS Subsidence Research Office, as reported by Lofgren in $1974 .^{1}$ The 


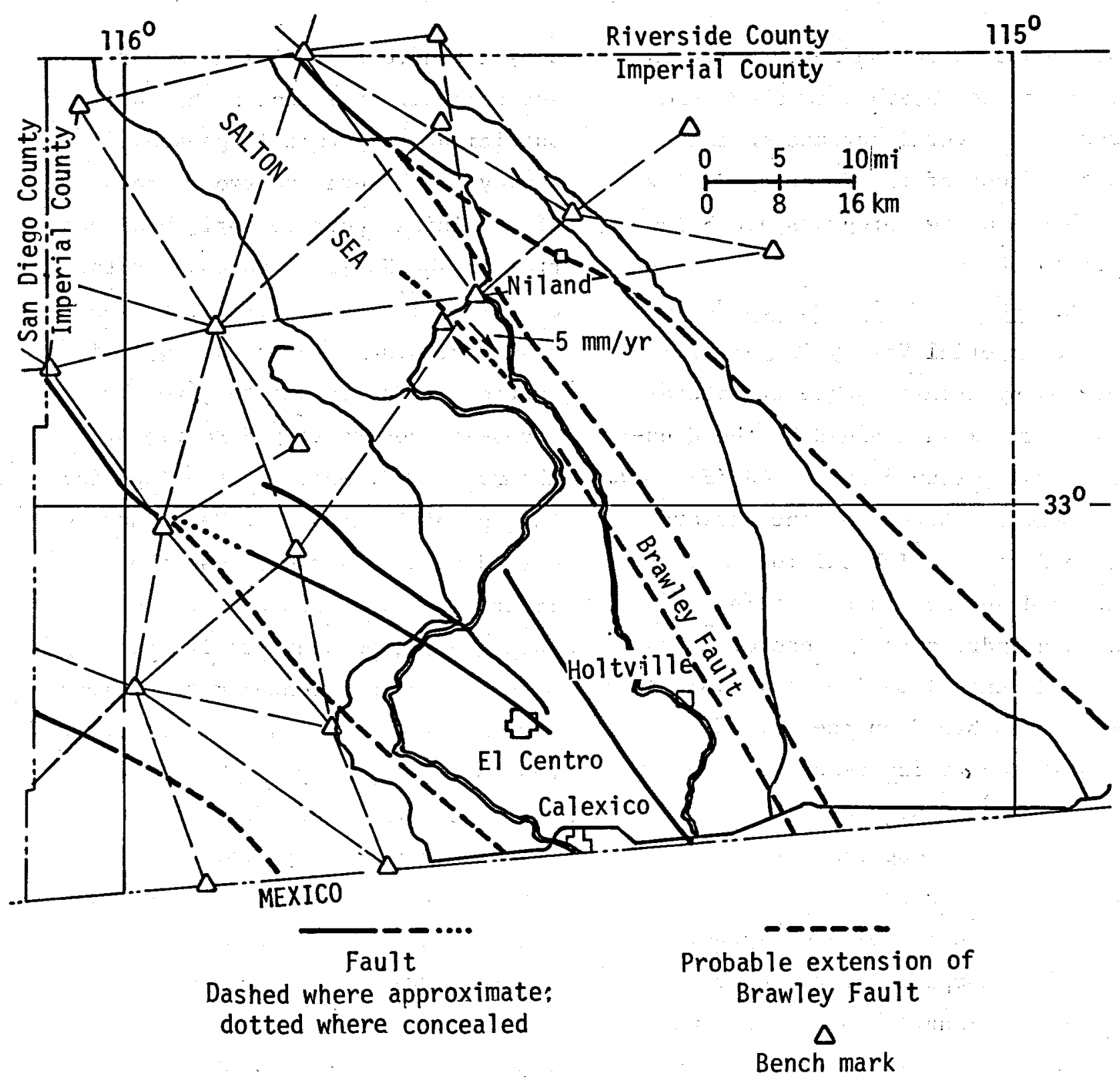

Fig. 3. Regional network of horizontal control; from Lofgren. ${ }^{1}$

equipment used is similar in principle to the distance-measuring equipment employed in large-scale trilateration, but is designed for smaller distances and is lower in cost. The results obtained over the shorter distances are equally accurate, and the surveys can be made at remarkably low cost. All that is necessary is to occupy a station with the instrument and move a target to any number of desired points nearby. The time required for each observation is very brief. Networks of this type have been established at Salton Sea, North Brawley, Heber, and East Mesa KGRAs. The network at the Salton Sea is shown in Fig. 4. We will discuss the necessity 


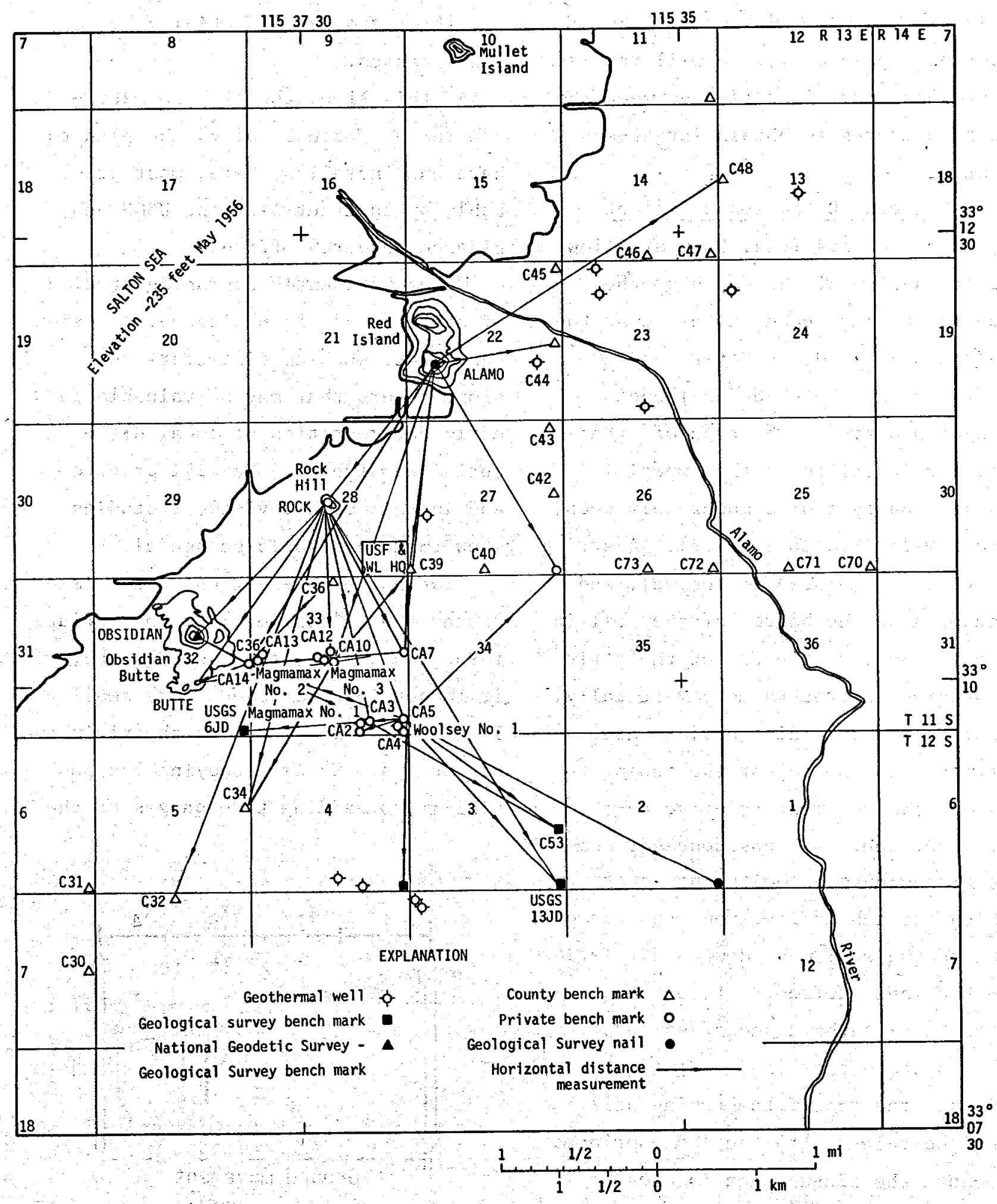

Fig. 4. Network of horizontal control in Buttes area; from Lofgren. 1 
and accomplishment of additionai local coverage with the Subsidence Research office; additionally, as mentioned previously, we will request a proposal for inter-ties between the local networks to obtain larger-scale control.

Subsidence Detection Equipment

Extensometers (Fig. 5) that allow determination of the depth of the subsidence have been installed at the Salton Sea field, at Heber, and at East Mesa by the USGS Subsidence Research Office. The type of extensometer installed in the Imperial Valley consists of a moderately deep, cased well ( 800 to $1200 \mathrm{ft}$ ). A string of tubing is placed in the well and anchored at the bottom of the well in such a way that the top of the string of tubing is free to move vertically. Appropriate recording devices are attached to the top of the tubing to record its movement relative to the land surface. If subsidence or compaction occurs below the point at which the tubing is fixed, the top of the tubing will move downward relative to the land surface. If, on the other hand, subsidence or compaction occurs above the fixed base of the tubing, the top of the tubing will move up relative to the land surface. Because the fixed point is chosen so that it is above the potentially productive geothermal reservoir but well below the surface, it will be possible to determine if a given subsidence effect is probably a result of geothermal activity or other causes.

At this time, there is no extensometer at North Brawley. We plan to have one installed there, most probably by contract with the USGS Subsidence Research Office.

We are presently beginning studies of other types of subsidence-detection equipment, such as tiltmeters and slope meters that may be valuable in early documentation of local differential subsidence. We will procure and install such devices if studies show that this would be useful.

Tide gauges are currently in place around the Salton Sea. By appropriate reduction of data from such gauges, it is possible to detect very small land surface movements in the vicinity of the Sea. We are studying the possibility of adding tide gauges at the

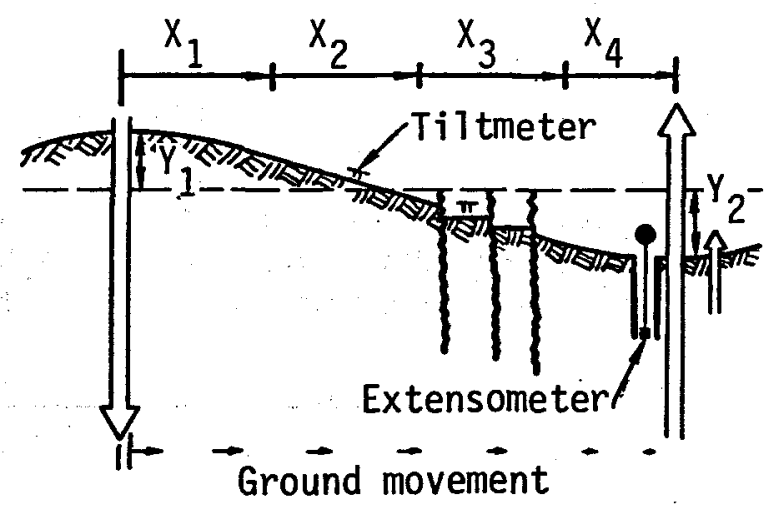

Fig. 5. Surface deformation in an extraction-injection area; from Lofgren. 1 
Sea in coordination with the activities of the Subsidence Research Office of the USGS and Imperial County.

\section{Subsidence Modeling}

We intend to make a study of subsidence, using the capabilities of the Earth Sciences Division at LLL.

It is intended to take advantage of other work being done to coordinate with the subsidence study. The phenomenon of land-surface subsidence involves three processes:

- the pore-pressure drop around producing wells resulting from fluid flow in the reservolr,

- the time-dependent compaction of the reservoir rocks, and

- the propagation of that compaction upwards towards the surface. Each process depends upon certain rock properties - porosity, pore pressure, permeability, and the strength of the rock-fluid system that include a time-dependent factor. The LLL rock-mechanics program can model and test in the laboratory the pressure-porosity behavior of sands and shales from the Imperial Valley. An attempt would be made to relate the response of material to measurable parameters such as major mineral content; grain, pore, and fracture size; permeability; and the like. Such relationships wotuld allow extrapolation to other areas. Joint LLL and Lawrence Berkeley Laboratory (LBL) field experiments are planned for the Salton Sea Geothermal Field to determine the communication between injection and production we1ls. Pressure measurements will be made in wells near a flowing well to estimate how easily injected fluid can migrate toward the production well, reducing the pore-pressure drop there. These measurements may allow an upper limit to be placed on the ultimate pressure drop assuming complete reinjection of fluid.

Because pressure drop is an important factor in the occurrence of subsidence, such information may be used to make some predictions of subsidence. Specifica11y, if the well-towell permeabllity is high and a small ultimate pressure drop is predicted, then an upper bound can be placed on the magnitude of subsidence. Knowing the extent of probable subsidence, we can assess the environmental impact more accurately.

\section{Seismicity Studies}

When production of geothermal fluids for electric-power production takes place in the Imperial Valley, it wi11 be necessary to reinject the fluid for the following reasons: disposal of the produced brine, maintenance of reservoir pressure; and control of subsidence, Seismic activity has been Induced in other areas of the U.S. by high-pressure injection of fluid into wells. Field 
experience at the Salton Sea Geothermal Field has been that injection can be carried out at low pressure; the pressure gradient formed at the formation face by the differential between the densities of the cooled fluid moving down the well bore and the hot water in place in the reservoir has been sufficient to permit injection of water into the formation. While low-pressure injection has not been implicated in inducing seismicity, the possibility cannot be dismissed.

Detection of any earthquakes related to geothermal production will be complicated by the fact that the Imperial Valley is one of the most tectonically active regions in the United States. Furthermore, geothermal fields are usually associated with active faults, making it necessary to distinguish between naturally. occurring seismic activity and any increment resulting from geothermal development.

Two criteria are considered to be useful for detecting induced earthquakes: a change in the frequencymagnitude statistics in the vicinity of the geothermal field and a change in the location (particularly depth) of events coincident with geothermal production. Both criteria require baseline measurements of the seismicity in the Imperial Valley before geothermal production begins, and our program presently centers on obtaining such baseline data.

Vertical Seismometer Network

The U.S. Geological Survey has maintained a 16-station seismograph network in the Imperial Valley for 3 years (Fig. 6). A major objective of our program has been the strengthening of this network. One of our major accomplishments this year has been the issuance of a contract to the USGS to install six seismograph stations in the vicinity of the Salton Sea Geothermal Field; the network is shown in Fig. 7. Installation of the stations was completed late in the fall of 1976, and the stations have been connected to the USGS data-processing network. The stations provide detailed coverage of the immediate area. As a result of the installation of these stations, the regional network has been expanded to provide uniform coverage of the Imperial Valley from the Salton Sea to the Mexican border. The network was designed to locate all events in the Valley with Richter magnitude greater than 1 to 2 . Smaller events are masked at large distances by the high seismic noise level in the region. The Valley-wide seismic network is providing data for frequencymagnitude statistics that will be applicable to any geothermal area. in the Valley. The contract also 


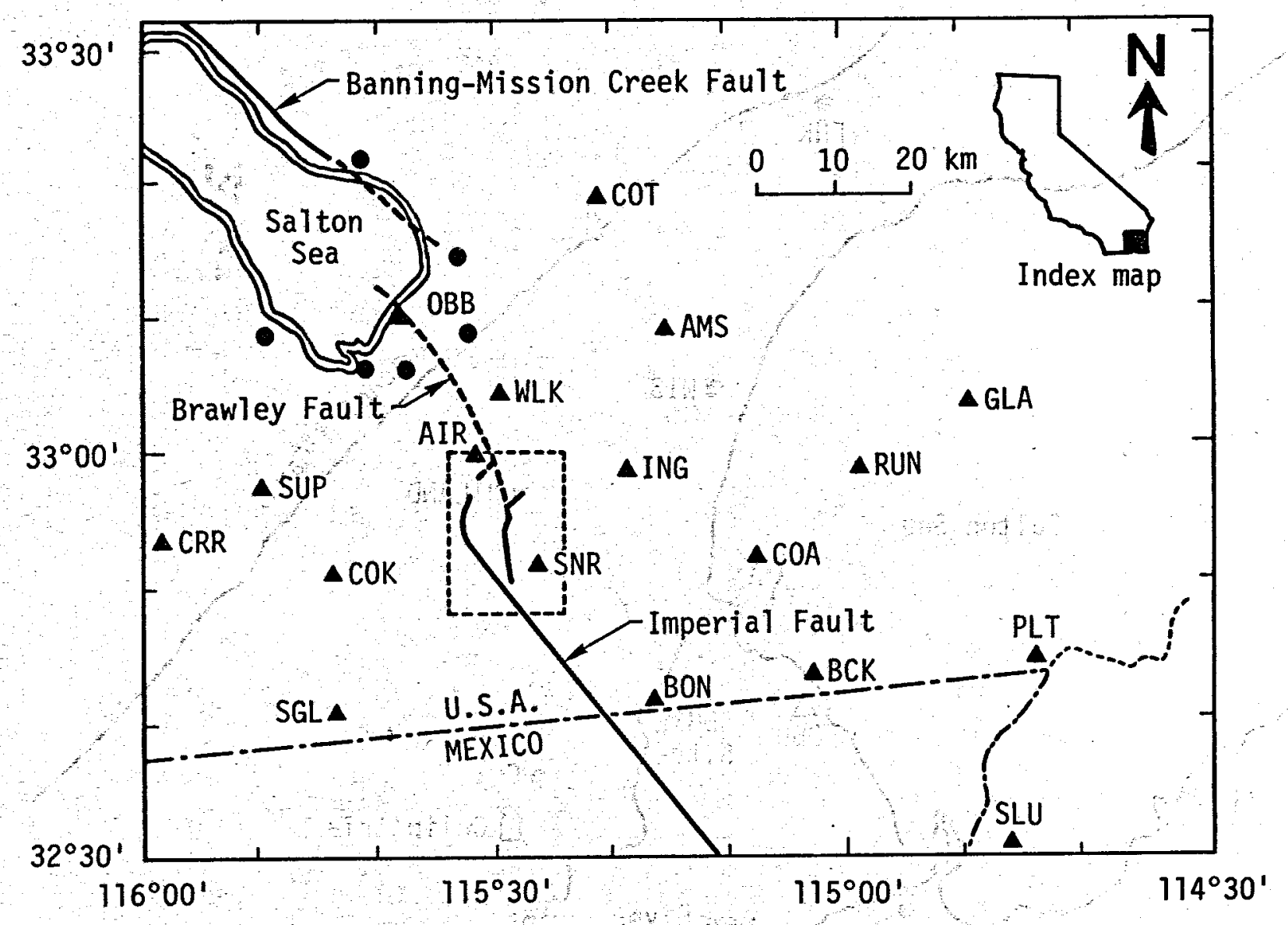

Fig. 6. Seismograph network in Imperial Valley (USGS) (A), showing added ERDA/LLL stations near Salton Sea geothermal field $(\bullet)$. (Modified from Johnson and Hadley, ${ }^{2}$ )

provides the USGS with a number of portable stations to be placed in. case a swarm of earthquakes occurs; if set up immediately in the vicinity of a swarm, such portable stations can provide invaluable information about the seismic behavior during such events. A11 data from the network will be furnished to us as a part of the contract.

We are presently designing additional local networks in the vicinity of geothermal fields from which power production is planned. Smal1-scale networks will be designed to provide more accurate hypocenter* locations and sensitivity to earthquakes of smaller magnitude near the geothermal fields. Local networks already exist at two of the fields:

* The hypocenter of an earthquake is the point within the earth at which the earthquake occurs - In other words, the focus. The epicenter of an earthquake is the point on the earth's surface directly above the hypocenter or focus. 


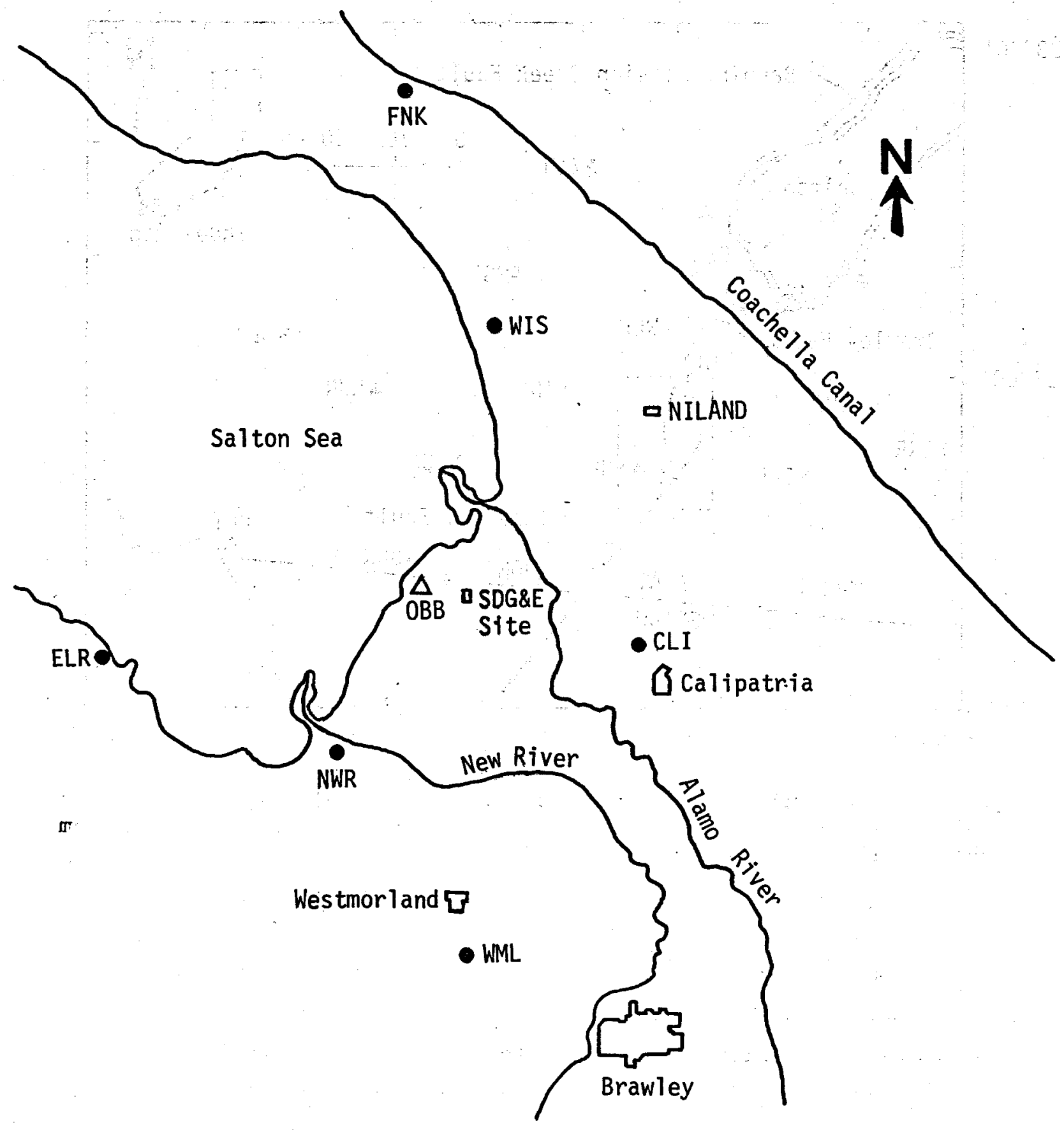

$\Delta$ Existing seismic station

New seismic stations

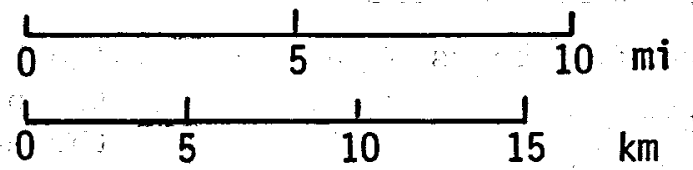

Fig. 7. Detail of seismic network in Salton Sea area. 
the LLL-sponsored expansion of the USGS network near the Salton Sea field covers that area, and the Bureau of Reclamation is operating a network at East Mesa. Networks will be installed at Heber and North Brawley, using designs developed in close coordination with the companies planning to produce the fields and the USGS. The design of the local networks will be based on computer codes used by the LLL Seismic Monitoring Program to estimate the resolution of a seismic network, assuming a level of seismic noise and uncertainty in seismic-velocity models. An extremely important aspect of discrimination between natura11y occurring and induced earthquakes is the avallability of a correct model of seismic velocity. The effects of the errors produced by use of an erroneous model can be very important if depth of the event is one criterion for labeling a natural earthquake. Recent evidence indicates that this criterion may be useful. Johnson and Hadiey at the California Institute of Technology have studied the results of selsmographic data around the Brawley earthquake swarm of January 1975. The hundreds of events comprising the swarm were shown to occur below the sedimentary layers at a depth greater than $4 \mathrm{~km}$ (Fig. 8). Geothermal production and reinjection would affect these sedimentary 1ayers and would not be expected to cause deeper events. Unfortunately the potential error in depth location for these earthquakes is substantial because of an inadequate velocity model for the Imperial Valley. Two field studies will enable improvement of seismic velocity models for the Valley: the USGS plans calibration explosions to provide known inputs into the regional system, including the new Salton Sea stations, for FY 1977; and in March-April 1975, LLL sponsored a seismic-refraction survey in the Salton Sea KGRA area by the University of California at Riverside. The refraction survey included the detonation of a relatively large explosion to obtain the data. The data obtained from these two studies will provide input for construction of a new seismicvelocity model. With seismographic records of the travel time of an energy input of known magnitude, it is possible to calculate the characteristic velocities of each of the different kinds of rocks in the region. Because the velocity model is so 1mportant for correct interpretation of seismic events, we believe that construction of a new model is a vital part of our program. We will construct this during FY 1977. 


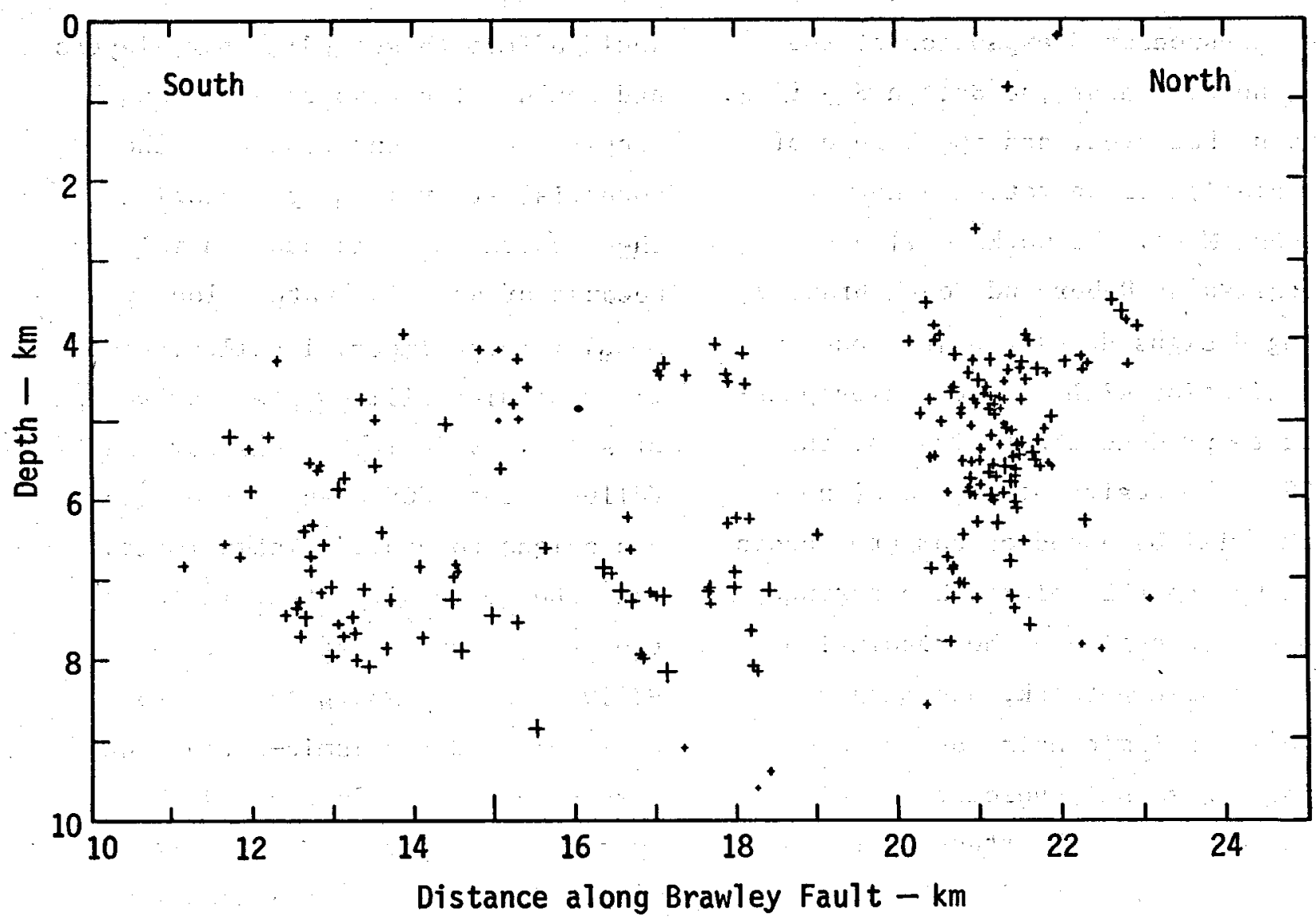

Fig. 8. Hypocenters of earthquakes, Brawley swarm of January, 1975. Magnitude of earthquake indicated by size of čross; from Johnson and Hadley. 2

\section{References}

1. B. E. Lofgren, "Measuring Ground Movement in Geothermal Areas of Imperial Valley, California," Proc. Conf. Res. Dev. Geothermal Energy Resources, Pasadena, California, September 23-25, 1974, pp. 128-138; National Science Foundation, Rept. NSF-RA-N-74-159.

2. C. E. Johnson and D. M. Hadley, "Tectonic Implications of the Brawley Earthquake Swarm, Imperial Valley, California, January 1975," preprint of a paper given at the Fall Meeting, American Geophysical Union, San Francisco, December 1975. 

SOCIOECONOMIC EFFECTS

Kenda11 F. Haven

General -

The three goals of the IVEP Socioeconomic Impact Assessment program are to characterize the potential range of local impacts of a largescale geothermal development, to identify the actors and actions within the socioeconomic sphere that are capable of affecting the progress of geothermal development and its impacts, and to identify potential areas of conflict that are associated with large-scale geothermal development. Task definitions and task sequential flows were defined during initial planning for the IVEP.

\section{Progress Summary}

The first IVEP status report ${ }^{1}$ included general socioeconomic methodology, initial coordination efforts, and task organization. Since that date (March to 1 October 1976) the following progress in the socioeconomic program element was made:

- Four reports ${ }^{2-5}$ have heen completed and submitted for publication as laboratory reports that cover all aspects of the characterization of the Imperial Valley socioeconomic system.

- All tasks scheduled are now active and on-schedule with the exception of two, the Salton Sea Recreational Study and the Fiscal Service Stress
Analysis. The basic cause for these delays is a lack of requested manpower. Both studies will be covered later through outside contracts.

- Tasks and subtasks for three supporting contracts (approximately $\$ 50,000)$ for the socioeconomic element have been identified, potential vendors contacted, and contracts submitted to the LLL Purchasing Department.

Individual Task-Progress Summary.

Several major tasks in the socioeconomic element were scheduled for initiation or continuation during the March tò October 1976 period.

On-Going Program Coordination. Active program coordination and arrangements for information exchange are being maintained with a number of local, state, and private sector organizations (see Table 1): To date this information exchange has been used for scenario development and for characterization of the existing system.

Characterization of the California and Imperial County Electrical

Flow Systems.

This study was completed and the resulting report submitted for publication. 5 In addition to the characterization of the county according to the quantity of electrical energy flow from the county to other parts of 
Table 1. On-going relationships with outside organizations,

\begin{tabular}{|c|c|c|c|}
\hline organization & $\begin{array}{l}\text { General } \\
\text { program } \\
\text { coordination }\end{array}$ & $\begin{array}{l}\text { Baseline } \\
\text { information } \\
\text { exchange }\end{array}$ & $\begin{array}{l}\text { Scenario } \\
\text { development }\end{array}$ \\
\hline Imperial County staff & $\mathrm{x}$ & $\mathrm{x}$ & $\mathrm{x}$ \\
\hline University of California, Riverside & $x$ & $\mathbf{x}$ & $\mathrm{x}$ \\
\hline California Institute of Technology & $\mathrm{x}$ & $x$ & \\
\hline $\begin{array}{l}\text { University of California, Berkeley } \\
\text { Agricultural Extension }\end{array}$ & $\mathrm{X}$ & $\mathbf{x}$ & $\therefore \mathbf{X}$ \\
\hline $\begin{array}{l}\text { University of California, Berkeley } \\
\text { Sea Grant Program }\end{array}$ & $\mathrm{X}$ & 2 & \& \\
\hline $\begin{array}{l}\text { California Energy Resources } \\
\text { Conservation and Development } \\
\text { Commission }\end{array}$ & $\mathbf{x}$ & & $\mathrm{X}$ \\
\hline Jet Propulsion Laboratory & $\mathrm{x}$ & $\mathrm{x}$ & $\mathbf{X}$ \\
\hline $\begin{array}{l}\text { U.S. Environmental Protection } \\
\text { Agency }\end{array}$ & $\mathrm{x}$ & $\therefore \div$ & $\therefore$ \\
\hline $\begin{array}{l}\text { California State office of Planning } \\
\text { and Research }\end{array}$ & $\mathrm{X}$ & $x$ & 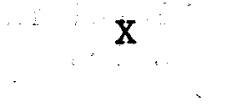 \\
\hline Engineering Economics, Inc. & $\mathrm{x}$ & $\mathrm{x}$ & \\
\hline Geonomics, Inc. & $\mathrm{x}$ & $\mathrm{x}$ & \\
\hline Economic Sciences, Inc. & $\mathrm{x}$ & $\mathrm{x}$ & $\mathrm{x}$ \\
\hline $\begin{array}{c}\text { California State Employment } \\
\text { Development Department }\end{array}$ & $\mathrm{X}$ & $\mathrm{x}$ & r \\
\hline
\end{tabular}

California (see Tables 2 and 3 for examples of typical information for Imperial County), linear-regression analysis was made to detect significant correlations between the county level of energy consumption and major: characteristic parameters in the county not related to energy.

\section{Imperial County Economic, F1scal,} and Social Characterization.

Initial characterization of the Imperial County Economic, Fiscal, and Soclal structure has been completed on schedule and reported. ${ }^{2-4}$ These results are summarized in the Integrated Assessment section of this report. 
Table 2. Imperial County electrical energy budget for 1972 and 1974 .

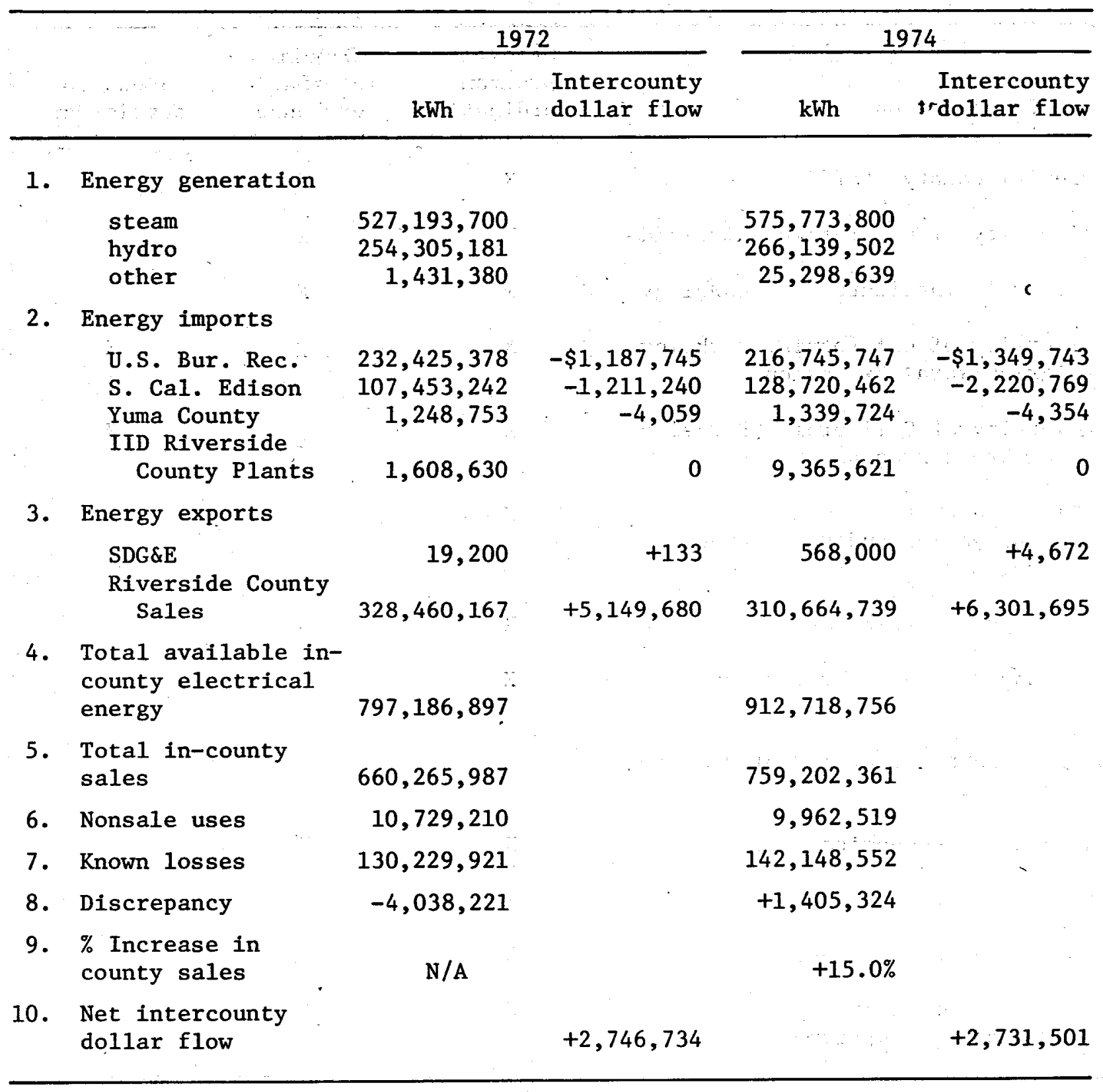

Comparative Area Study:

Many tentative study sites for a comparative case-study analysis have been reviewed to date. Table 4 ists the principal sites still under consideration for comparison to development in Imperial County. Basic characterization data for these sites $\ldots$; have been collected; however, data analysis has not proceeded.

\section{Model Identification and}

Development.

The two major models for this study are an economic sectoral model and a county/subcounty fiscal model. A 1972 base year input/output model 
Table 3. Imperial County electrical energy sales and use data for 1972.

\begin{tabular}{|c|c|c|c|c|c|}
\hline \multirow{2}{*}{ ( } & \multirow{2}{*}{$\begin{array}{l}\text { totals } \\
\% \text { of } \\
\text { state } \\
\text { total }\end{array}$} & \multirow[b]{2}{*}{ Rank } & \multicolumn{3}{|c|}{ County per capita } \\
\hline & & & & Rank & \\
\hline 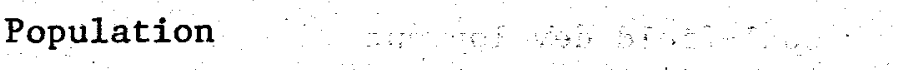 & 0.38 & 32 & & 32 & . \\
\hline Residential electrical sales $276,337,423$ & 0.69 & 28 & & 16 & $\therefore$ \\
\hline Commercial electrical sales $\quad 256,908,979$ & 0.54 & 30 & & 15 & \\
\hline Industrial electrical sales $\quad 76,738,153$ & 0.19 & 30 & & 34 & \\
\hline Sales to public sector $\quad 50,525,443$ & 0.47 & 22 & & 12 & \\
\hline Total commercial use & 0.54 & 30 & & 16 & \\
\hline Total industrial use & 0.19 & 30 & & 34 & \\
\hline Total public sector use & 0.39 & 23 & & 12 & \\
\hline Total sales & 0.47 & 28 & & 19 & \\
\hline Tota1 county use & 0.46 & 29 & & 20 & \\
\hline
\end{tabular}

was developed in March 1976 by Engineering Economics, Inc. under a National Science Foundation grant and updated to reflect 1975 changes. Efforts in this program are being directed toward refinement of recreationally related sectors and agricultural sectors within this basic model. Predictive modeling of the impact of geotherma1 development on the Imperial County economy will be based on historical information for The Geysers development in Sonoma County. A basic county per-capita-service model for Imperial County based on 1975-76 data is under development. This model will be refined and extended to subcounty levels under a contract with U.C. Berkeley. A recreational study of the Salton Sea area is being carried out under contract for the assessment of the impact of major alterations in that resource. A11 model identification and development activities are proceeding on schedule with original time estimates.

Initial Scenario Development.

Basic power-production scenarios for each major Imperial County KGRA are being developed by the Jet Propulsion Laboratory (JPL). These scenarios will be used without alteration by this program. Scenario elements developed by this program include direct-employment and population changes, tax revenues associated with geothermal development, and developmental constraints. Figure 
Table 4. Potential comparative area study case sites.

\begin{tabular}{lll}
\hline \multicolumn{1}{c}{ State } & \multicolumn{1}{c}{ Site area } & \multicolumn{1}{c}{ Type of development } \\
\hline California & Sonoma County & The Geysers geothermal \\
Oregon & Clatsop County & Major industrial (aluminum plant) \\
Wyoming & Campbell County & Coal-field development \\
Wyoming & Sweetwater County & Coal-field development \\
Idaho & Idaho Falls & National Reactor Test Station \\
Montana & Rosebud County & Coal-field development \\
North Dakota & Jamestown & General industrial development \\
North Dakota & Mercer County & Coal-field development \\
North Dakota & Stark County & Coal-field development \\
Colorado & Mesa County & Oil-shale development \\
Colorado & Garfield County & Oil-shale development \\
Colorado & Pitkin County & General service-related development \\
Ohio & Carroll County & Coal strip mining \\
Ohio & Harrison County & Coal strip mining \\
Texas & Not yet selected & On-shore oil-field development \\
Louisiana & Not yet selected & On-shore oil-field development \\
Florida & Escambia County & Oil-field development \\
Indiana & Pike County & Coal strip mining \\
Rhode Island & Tiverton & Refinery construction \\
\hline & & \\
\hline
\end{tabular}

1 shows the areas that are potentially excluded from geothermal development if power plants were prohibited from: the preservation zones of the county and within a half mile of their boundaries, cities and within a mile of their boundaries, the Salton Sea, critical habitats and wildlife refuges, and within a mile radius of feedlots, schools, and hospitals. Constraint analyses are based on county-zoning ordinances, county. ultimate-land-use plans, state and federal preserves and critical habitat areas, and various proposed plans for the Geothermal Element of the County General Plan. The socioeconomic portion of this work has been completed.

\section{Preliminary Assessment.}

Work on a preliminary assessment is now under way based on preliminary scenarios, system characterization, and project models mentioned above. 


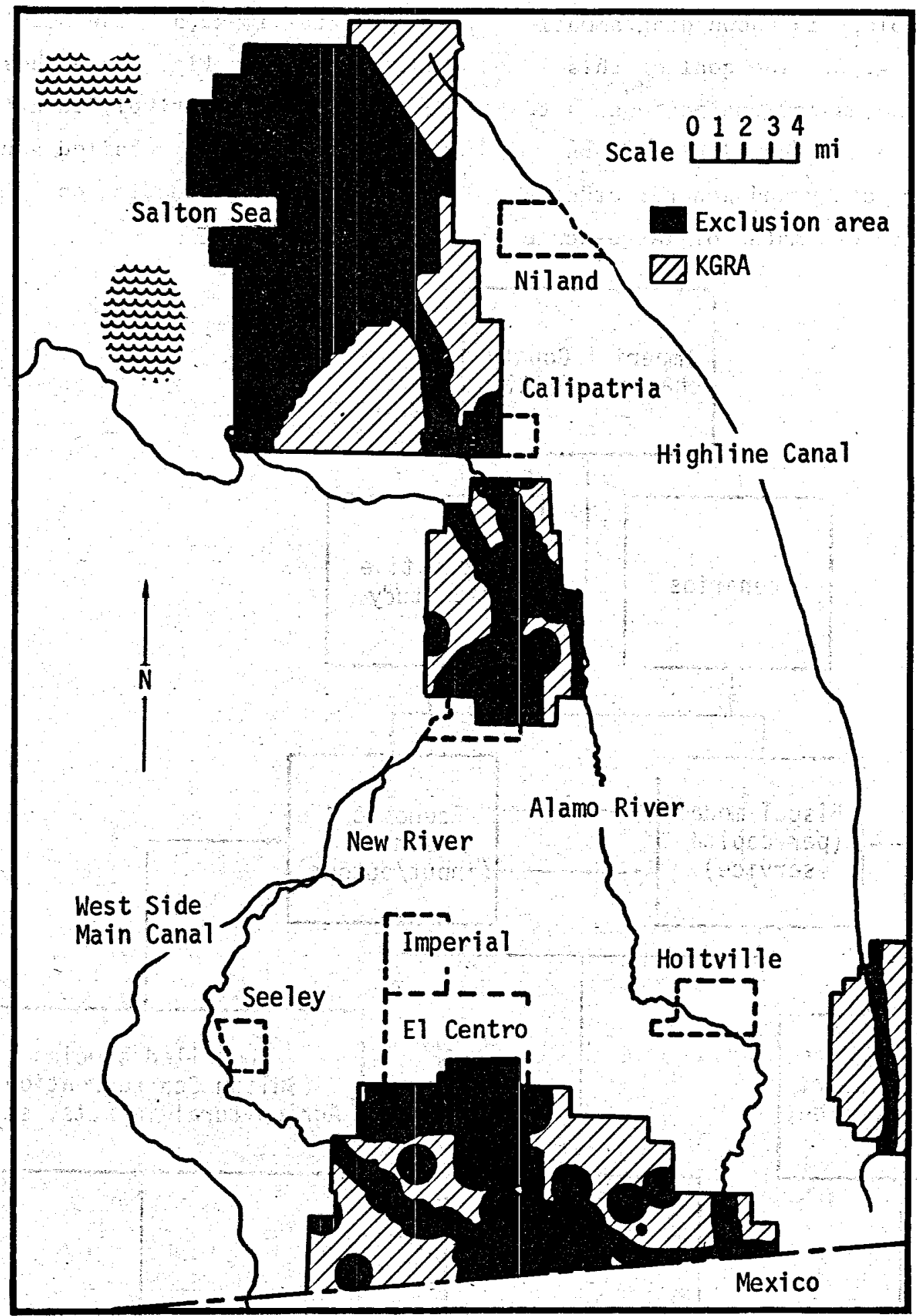

Fig. 1. Areas potentially excluded from geothermal development if power plants are restricted from: preservation zones and within a half mile of their boundaries, cities and within a mile of their boundaries, the Salton Sea, critical habitats and wildlife refuges, and areas within a mile radius of feedlots, schools, and hospitals. 
The methodology is shown diagrammatically in Fig. 2. The goal of this phase of the assessment process is to identify areas of critical concern for further study and general orderof-magnitude estimates of 1arge-scale developmental impacts. The Detailed Studies listed on Fig. 2 are those that have been tentatively identified as areas for further detailed study. Work on this is proceeding on schedule.

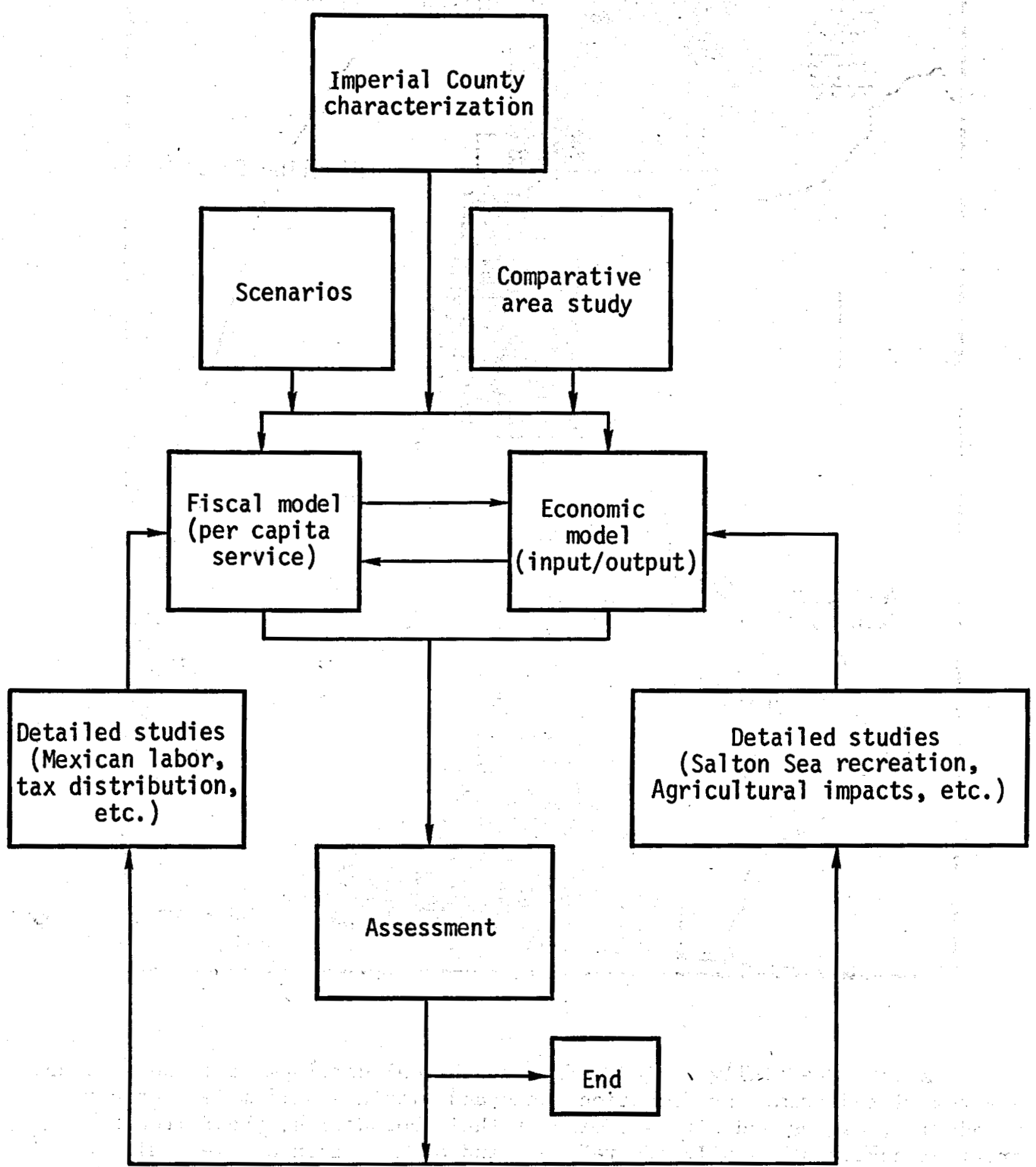

Fig. 2. Assessment methodology for socioeconomic impacts. 


\section{References}

1. L. R. Anspaugh and P. L. Phelps, Eds., An Overview of the Imperial Valley Environmental Project, Lawrence Livermore Laboratory, Rept. UCID-17067 (1976).

2. K. F. Haven, "County Economic Characterization," in A Description of Imperial Valley, Califomia, for the Assessment of Impacts of Geothermal Energy Development, (D. W. Layton and D. L. Ermak, Eds.), Lawrence Livermore Laboratory, Rept. UCRL-52121 (in press).

3. K. F. Haven, "County Fiscal Characterization," in A Description of Imperial Valley, Califormia, for the Assessment of Impacts of Geothermal Energy Development, (D. W. Layton and D. L. Ermak, Eds.), Lawrence Livermore Laboratory, Rept. URCL-52121 (in press).

4. K. F. Haven, "Social Characterization of Imperial County," in A Description of Imperial Valley, California, for the Assessment of Impacts of Geothermal Energy Development, (D. W. Layton and D. L. Ermak, Eds.), Lawrence Livermore Laboratory, Rept. UCRL-52121 (in press).

5. K. F. Haven, The 1972 Flow of Electrical Energy in California and Its Relationship to Selected County Level Characteristic Parameters, Lawrence Livermore Laboratory, Rept. UCRL-52143 (1976). 

IMPERIAL VALLEY ENVIRONMENTAL PROJECT

Health Effects 
HEALTH EFFECTS

Lynn R. Anspaugh

During initial planning for the Imperial Valley Environmental Project (IVEP), it was recognized that a health-effects element of the Project would be highly desirable. This was not because adverse health effects from geothermal effluents were anticipated on the basis of known facts, but because health effects are the endpoint of major concern. A complete integrated project must therefore address health effects, and not merely by the completion of calculational exercises without the benefit of actual data. The collection of health-effects data beyond readily available mortality statistics, however, can be very difficult and expensive. On the other hand, the population in Imperial County is rather small, and the possibility of detecting actual health effects due to geothermal effluents is severely limited if only mortality data are available. Because of these conceptual design dilemmas and because any conceivable health effects would not be expected for several years, it was decided to delay the implementation of health-effects studies. Personnel of the Division of Biomedical and Environmental Research (DBER) of the Energy Research and Development Administration (ERDA) concurred in this decision. Since then, the ERDADBER has designated a Manager for
Human Health Studies Programs, who would have ERDA funding and scientific management responsibility for an IVEP health-effects study.

Efforts have continued to define a health-effects program that will be implemented during 1977. Contacts have been established with the Epidemiological Studies Laboratory and the Air and Industrial Hygiene Laboratory of the California Department of Health and with the Imperial County Health Department. It is anticipated that these agencies will be funded to perform much of the actual health studies. The California Department of Health has had relevant experience ${ }^{1}$ in conducting studies in the vicinity of pulp mills, which also release $\mathrm{H}_{2} \mathrm{~S}$.

We anticipate that the healtheffects studies will include four major tasks. The first will be to examine available source-term data for expected effluents and to review the relevant scientific literature for known health effects. The expected output would be a published review that would contain dose-response curves for specific effluents, a relative ranking of the effluents in terms of possible effects, and recommendations for basic health-effects research, if appropriate. The need for dose-response curves is great, not only for geothermal energy but for all energy sources. It is unfortunate that at least one author ${ }^{2}$ has 
attempted to set health-effects priorities for geothermal effluents based upon the naive assumption of a universal no-threshold, linear-dose response. This resulted in very high priorities assigned to manganese and fron, two elements which are essential for human health.

The second task would to be estab11 sh an exemplary program for reporting health statistics in Imperial County. The goals would include a more rapid accumulation of mortality data in a form suitable for summarization and analysis, and comparison of these data to past trends in Imperial County and to data for the entire U.S., the State of California, and counties of similar characteristics. Morbidity data would also be collected from avallable sources such as hospitals and records kept by other government agencies. Such a program should be of significant benefit to Imperial County and State health authorities for numerous purposes.

The third task would be to conduct community-response surveys. The purpose would to be document the perception of the annoyance and health effects of odor pollution in Imperial County. This aspect of the study is primarily oriented toward the potential effects of $\mathrm{H}_{2} \mathrm{~S}$ emissions. These response studies would include measurements of $\mathrm{H}_{2} \mathrm{~S}$ concentrations in ambient air and measurements of odor pollution by dynamic olfactometry. These studies should be structured to provide baseline data, as Imperial County has many current sources of odor pollution such as feedlots. Resurveys would be necessary as geothermal development proceeds.

The fourth task would be to review occupational health programs at all geothermal facilities and to examine whether special health monitoring programs would be desirable. Such programs would have the goals of providing added protection to occupational personnel and in providing the earliest possible detection of health effects should they occur. 


\section{References}

1. J. R. Goldsmith; Ed., Health and Annoyance Impact of Odor PolZution, U.S. Environmental Protection Agency, Rept. EPA-650/1-75-001, NTIS, Springfield, Va. (1973).

2. L. Schieler, "Geothermal Effluents, Their Toxicity and Prioritization," in Proc. First Workshop on Sampling Geothermal Effiuents, Las Vegas, Nevada, October 20-21, 1977, U.S. EPA Environmental Monitoring \& Support Laboratory, Las Vegas, Nevada, Rept. EPA-600/9-76-011 (1976). 
IMPERIAL VALLEY ENVIRONMENTAL PROJECT

Integrated Assessment 
INTEGRATED ASSESSMENT

Introduction

David W. Layton

An end goal of the Integrated Assessment Program is to produce a set of impact assessments of alternative geothermal scenarios in the Imperial Valley. Other important responsibilities of the program are to review the adequacy and relevancy of the data measurement programs and to transfer information to government agencies, legislative bodies, and planning groups.

To conduct the assessment, work has proceeded in several areas. First, relevant historic information has been collected on the region and presented in a general report. Work has also progressed on a set of geothermal energy scenarios which include levels and timing of energy production, technology characterizations, and considerations of power plant siting criteria. Concurrent with the scenario development has been the modification of a Gaussian air pollution model for use in preliminary air quality assessments. This effort will serve as a basis for a more detailed modeling study to be conducted in conjunction with the Air Quality Element. The impacts of gaseous pollutants on selected crops will be simulated by a crop growth model that has been developed during the past year. Additional work has been done on legal analysis of geothermal legislation and on the legal aspects of water supply utilization. Research on the potential water resource impacts of geothermal facilities rounds out the initial assessment tasks.

Data acquired by the measurement groups (i.e., air quality, water quality, ecosystem quality, etc.) of IVEP have been systematically entered into a data base for future retrieval and analyses. And as part of the information transfer function of the Integrated Assessment Program, data is now being prepared for submission to the Air Resources Board of California. Important contacts have been made with Imperial County and the Imperial Irrigation District, the primary political units in the Valley, in order to facilitate the exchange of information.

Description of the Imperial Valley, California

Donald L. Ermak and David W. Layton

Before an assessment of the impacts of geothermal energy development in the Imperial Valley can take place, the existing physical and biological environments of the region must be characterized. Therefore, the initial efforts of the Integrated Assessment group in the IVEP were to acquire relevant background information on the Valley, to analyze it, and then to describe significant features that 
would affect future assessments. The end product of those tasks is a report entitled, "A Description of Imperial Valley, California, for Assessment of the Impacts of Geothermal Energy Development," edited by David Layton and Donald Ermak. 1

Principal features of the Valley include:

- The irrigation of about 475,000 acres of agricultural lands,

- A desert climate characterized by an annual rainfall of under 3 inches, hot summers, and mild winters,

- High particulate loadings in the atmosphere that exceed annual primary and secondary air-pollution standards,

- Nearly three million acre-feet of water imported from the Colorado River each year,

- Surface-water salinities that vary between $900 \mathrm{ppm}$ total dissolved solids (TDS) in canals to over $39,000 \mathrm{ppm}$ TDS in the Salton Sea,

- An agricultural economy dominated by livestock and dairy products, field crops, and vegetable crops,

- A soil-salinity problem that has necessitated the development of an extensive subsurface-drainage system,

- The existence of a sport fishery in the Salton Sea as well as state and federal game refuges,
- A geotherma1-energy potential of over 4,000 megawatts for 25 years, - A county budget of $\$ 38.7$ million during fiscal year 1976 for a percapita budget of $\$ 519.8$, and

- A county population of just under 84,000 in 1974.

The following paragraphs, taken from the introduction of the Imperial Valley characterization report, contain additional background information.

Land and Air Resources

"The Imperial Valley occupies the lowest part of the Colorado Desert. It receives water from the Colorado River to support about 475,000 acres of irrigated lands. The waste waters from these lands help sustain the Salton Sea, California's largest inland body of water. Geologically the Valley is characterized by earthquakes, active faults, and natural subsidence. Hot summers, mild winters, and an average annual rainfall of under 3 inches define its climate; stable atmospheric conditions, westerly winds, and night time inversions are important meteorological features. The most prominent characteristic of the air quality is the high levels of suspended particles that exceed federal standards.

\section{Water Resources}

"Near1y 3 million acre-feet (af) of Colorado River water are diverted 
to the Valley each year by the Imperial Irrigation District. To distribute that water and remove unwanted waste waters, over 3,000 miles of canals and drainage ditches cover the Valley. Waste waters entering the Salton Sea have caused its level to rise for many years, and the sea is now at its highest elevation in recent years. Surface water salinity ranges from about $900 \mathrm{ppm}$ total dissolved solids (TDS) in the A11 American Canal to almost 39,000 ppm in the Salton Sea. Sediments underlying the Valley contain more than a billion acre-feet of ground water having salinity less than $35,000 \mathrm{ppm}$. Natural recharge in this arid region is quite low, yet millions of acrefeet have been added to shallow aquifers from canal seepage.

\section{Biological Resources}

"There is an extensive, irrigated agricultural region, a quasi-marine inland saltern ecosystem, state and federal game reserves with many shorebirds and waterfow1, five endangered species of birds, freshwater and riparian ecosystems, and extensive desert communities in the Imperial Valley. Agricultural lands produced gross sales in 1974 of $\$ 557$ million of which $\$ 155$ million was in livestock and dairy products, $\$ 284$ million in field crops, and $\$ 103$ million in vegetable crops. In acreage harvested, the most important crops are alfalfa, wheat, cotton, sugar beets, lettuce, sorghum, pasture ryegrass, cantaloupes, carrots, barley, asparagus, onions, and tomatoes. The unique climate is such that most vegetable crops grow in the winter months and most field crops grow in the spring and summer months. Soil salinity problems are important in the Valley and require large amounts of Colorado River water for leaching and an extensive underground pipe drainage system to carry off water and dissolved salts. The leached salts are eventually emptied into the Salton Sea. Of the many attempts to introduce new species into the Sea, only a few have been successful. Currently there are eight fish and seven invertebrate species. The sea has high levels of nutrients that create an unusually high productivity $\left(0.75 \mathrm{~g} / \mathrm{m}^{3} /\right.$ day of carbon fixation). Extensive shorebird (35 species) and waterfowl (47 species) (excluding swans, ducks, geese, cranes, and rails) populations exist around the Salton Sea especially in the state and federal game refuges. The Salton Sea is on the Pacific Flyway and hosts large migratory populations (a total of 9.7 million waterfowl use days in 1971 for the Salton Sea National Wildlife Refuge). Outside the irrigated areas in the Valley lies the Sonoran desert. Typical desert communities of creosote brush, sage, mesquite, ironwood, and desert 
wi1low dominate the Glamis, East Mesa, and Dunes Known Geotherma1 Resource Areas (KGRAs). In these KGRAs some areas are dominated by dune communities of very sparse vegetation and a shifting, sandy soil. The balance of the area in these KGRAs is mixed bajada (alluvial fans) communities or creosote communities.

\section{Geotherma1 Resources}

"As early as 1927 efforts were made to develop the geothermal resources in the Imperial Valley. Minera1 extraction, carbon dioxide recovery, and power production have all been attempted, but with limited success. Some of the current geothermal activities are electric power conversion research, impact studies of proposed geothermal projects, base-1ine environmental studies, and exploratory drilling. of the 6 KGRAs, only the Salton Sea, Heber, East Mesa, and Brawley areas are expected to be developed. Estimates of their total electrical potential are under 5,000 MW for 30 years. The Salton Sea KGRA has the greatest energy potential because of its high down-hole temperatures (average of $286^{\circ} \mathrm{C}$ ), yet it may be the hardest to develop since brines found there average over $200,000 \mathrm{ppm}$ TDS. In comparison, the Heber KGRA has geothermal fluids of around $20,000 \mathrm{ppm}$ TDS, while those of the East Mesa KGRA are about 2,100 ppm TDS. Other relevant characteristics of the geothermal fluids in the valley include a steam content of between 10 to $25 \%$ by weight and the presence of minor amounts of noncondensable gases. -

County Economic Characterization

"The Imperial County economy is dominated by agriculture, its associated support services, and product processing. Agricultural activities are dominated by beef cattle and by general field crops. In $1974,85.9 \%$ of the total valley acreage was planted in field crops with a total dollar value of $\$ 284$ million. There was a decline in beef production in 1974 with 720,000 head raised in valley feed lots (down from 798,000 in 1973) with a tota1 value of $\$ 151$ million (down from $\$ 186$ million in 1973). While strong in the agricu1tural sectors, the Imperial County economy is weak in manufacturing and construction activity compared to the state as a whole. Recent county employment patterns show a steady decline in agricultural employment (down $48 \%$ between 1960 and 1970 ) as agriculture has become more mechanized. During the same time, a steady increase occurred in nonagricúltural employment. Mexican greencard 1abor represents under $2 \%$ of the county nonagricultural employment and 
roughly $70 \%$ of the agricultural work force. Within the county, E1 Centro is the industrial, commercial, and general economic center representing well over half of all county retail sales. A second significant center is Calexico, which is located on the U.S.-Mexico border and serves both Imperial County and Mexican markets.

County Fiscal Characterization

"The Imperial County budget for fiscal year 1976 totaled $\$ 38.7$ million for a per capita budget of $\$ 519.8$. About $25 \%$ of the county's revenues that year came from the federal government, and a second $25 \%$ came from the state of California. Income from local taxes and fines accounted for $26.5 \%$ of the county's income. The remainder of fiscal 1976 income was derived from carry over and service charges.

During the fiscal year, $\$ 30.8$ million was spent on education by the school districts. The average cost per year per student in an elementary school was $\$ 1,220$, while that of a secondary school student was $\$ 1,385$. These figures have increased over the past decade by $110 \%$ for secondary education and by $170 \%$ for elementary education.

County Social Characterization

"The 1974 population of Imperial County is estimated to be just under 84,000; the 1970 official census figure was 74,492. Approximately
95\% of the population is concentrated on the agriculturally rich land of Imperial Valley. The 1970 census reveals major characteristics of this population: an unusually low percentage of young adults (ages 18 to 24); a high percentage of children under $13 \mathrm{yr}$ old; a large number of Mexican-Americans, as would be expected of a border county; the highest percentage of any California county of adults with minimal educational attainment (less than an 8th grade education); and, finally, income levels comparable to most other California counties.

Geotherma1 Laws

"Statutes and regulations made at federal, state, and county: levels have a strong influence on the development of geothermal resources in the Imperial Valley. The Geothermal Steam Act of 1970 governs the leasing of federal lands for geothermal projects. Important conditions of the Act are an acreage limitation on leases and the exemption of federal lands related to the protection of wildlife. Regulations promulgated under the legislation are designed to protect the environment as much as possible from the effects of geothermal development. The federal government also operates a loan guaranty program for geothermal projects. California statutes directly associated with geothermal 
resources control the leasing of state lands and the drilling of geothermal wells. Certification of geothermal power plants is done by the state's Energy Resources Conservation and Development Commission. Imperial County also has regulations that involve geothermal activities. Those regulations ensure that geothermal projects are conducted in a manner that is consistent with existing environmental laws and regulations, county land use zones, and other specific conditions."

\section{Geothermal Scenarios for Imperial} Valley

Donald L. Ermak

The goal of this task is to develop a set of scenarios that describe potential levels of geothermal development in Imperial Valley over the next 30 years. Each final scenario will include: the level of electric-power production for each known Geothermal Resource Area (KGRA) in Imperial Valley, the number and size of each power plant required to meet the power-production levels, the location of existing or planned geothermalpower plants, the designation of those geographical regions in which the remaining power plants are to be sited, the cooling water requirements and the residual emissions from the power plants. These scenarios will be evaluated under other tasks for the impacts upon air quality, available water, biota, agriculture, and human health. Current efforts are summarized below.

The Jet Propulsion Laboratory (JPL) is developing power-production scenarios for each Imperial Valley KGRA. A preliminary version of the JPL report ${ }^{2}$ has been reviewed. The nominal scenario calls for $4500 \mathrm{MW}$ of electric power production in Imperial Va1ley by 2020 . This is in fairly good agreement with the. maximum-power-production levels predicted by Towse $^{3}$ and other recent predictions (for a review see Ref. 4). Consequently, the power-production levels proposed by JPL will be used in the LLL scenarios for Imperial Valley.

The designation of geographical areas for future power-plant siting requires the consideration of numerous factors including resource location, available water, proximity to cities, conflicts in land use, and seismic risk. We are developing a set, of siting criteria for determining the areas of geothermal development for each scenario. The main criteria seem to be the following:

- Power plants must be located near ( $<1 \mathrm{mi})$ the geotherma1 wells since large energy losses occur in transporting geothermal fluids. 
- There is a maximum size for power plants (about $100 \mathrm{MWe}$ ) because of the distribution of the resources.

- There are exclusion areas (cities, habitats of endangered species, etc.) within the Imperial Valley KGRAs in which geothermal development cannot occur.

- The total size of the exclusion areas will be significantly affected by the buffer zones required by loca1 ordinances.

The emissions from geothermal power plants depend upon the chemical composition of the fluids, the geothermal technology, and the control technology. The chemical composition of the geothermal fluids for many of the wells in Imperial Valley have been analyzed. ${ }^{4}$ The amount of noncondensable gases associated with the fluids has not been measured in Imperial Valley; however, this is being pursued by the IVEP Air Quality field program and will be incorporated into the scenario development as the data are obtained. The possibility of an outside contract is now being considered for the technology description portions of this task because of personnel reductions in the Integrated Assessment group.

We are developing a set of preliminary scenarios to be circulated among the other working groups for review and for use as the basis for initial assessments. These scenarios will include:

- The electric power-production levei in MWe for each KGRA,

- The number and size of each power plant to be located in each KGRA,

- The locations of existing or proposed power plants, and

- The geographical areas for siting additional power plants to meet the proposed power-production leve1.

An LLL report covering the initial Integrated Assessment activities on scenario development is in preparation. 5

A Model of Crop Photosynthesis and Growth under Gaseous Pollutant Stress James R. Kercher

\section{Introduction}

One of the tools being developed for environmental assessments of the impact of geothermal development is a general model of photosynthesis and plant growth. This model is general enough for modification and parameterization for any of the number of crops grown in the Imperial Valley. The model simulates photosynthesis as a direct function of temperature, sunlight, $\mathrm{CO}_{2}$ concentration in air, stomatal resistance, and biochemical parameters of the plant. Indirectly, photosynthesis is treated as a function of relative humidity, plant 
moisture stress, and soil salinity since these parameters affect transpiration and stomatal resistance. A coupled set of ordinary differential equations is used to describe growth and allocation of photosynthate during the growing season. These equations contain temperature-dependent expressions for respiration to account for photosynthate 1oss. Respiration is modeled as two components, maintenance respiration and growth-dependent respiration.

A preliminary version of the model is currently implemented to run on LLL computers. This version is parameterized mainly with data taken from corn. Hypothetical environmental parameters are used for model testing and computer-code debugging. These values are typical of what might be expected in the summer months in $a$. temperate climate.

Mode1 Inputs

The model requires four types of data:

- Climatic data including latitude, incident-light levels, total radiation into canopy, total radiation absorbed by the ground, air temperature, precipitation, wind above the canopy, and wet- and dry-bulb temperatures.

- Plant parameters including parameters to calculate stomatal resistance as a function of light, temperature, and water stress; parameters to calculate the turbulent-diffusion resistance of the canopy and the wind profile; parameters to calculate leafboundary-layer resistance; values of cell-wall- and protoplasmdiffusion resistance of mesophy11 cells; biochemical parameters involved in photosynthesis; respiration rate of leaves at a base temperature and $Q_{10}$ value; maintenance-respiration rate per unit biomass; growth-respiration rate per unit biomass added per unit time; total-1eaf-area index of mature plants; growth parameters of leaf, stem, fruit, and root; and translocation parameters of leaf storage influencing photosynthesis and movement from leaf to main storage.

- Soil parameters including soil temperature; soil salinity; parameters for calculating soil-water potential from soịl-moisture content, soil resistance from soil conductivity; depth of soil compartment; and root resistance to water flow.

- Pollution data including daily maximum and diurnal distribution; and parameters for calculating photosynthesis reduction or enhancement as a function of pollutant load. 
Mode1 Structure: Photosynthesis and Growth

The model structure is outlined in Fig. 1. Atmospheric $\mathrm{CO}_{2}$ diffuses into the plant to the chloroplast through the leaf-boundary 1ayer, the stomata, the cell wall, and the protoplasm. Leaf-boundary-layer resistance is determined by wind. Stomatal resistance is determined by light level, temperature, and water stress. The $\mathrm{CO}_{2}$ is then converted to $\mathrm{CH}_{2} \mathrm{O}$ by the absorption and conversion of the energy of light quanta (photosynthesis). Light levels are calculated in the canopy as a function of time of day and canopy structure. The thickness of the canopy (leaf-area index F) is determined by the biomass in the leaf- structure compartment, $x_{1}$. The photosynthate generated in the canopy is entered into a leaf-storage compartment, $x_{2}$. From the leaf-storage compartment, the photosynthate first meets the demands of the leafstructure compartment including growth, respiration, and maintenance respiration. Remaining photosynthate is translocated, $\mathrm{T}_{3}$, to the main-storage compartment, $\mathrm{x}_{3}$. The respiration demands, including both maintenance and growth respiration, of main storage, stem $x_{4}$, fruit $x_{5}$, and roots $x_{6}$ are met by main storage. In addition, main storage meets the growth demands $\left(T_{4}, T_{5}\right.$, and $\left.T_{6}\right)$ of compartments $x_{4}$, $x_{5}$, and $x_{6}$. The equations for growth and allocation are,

$$
\begin{aligned}
& \frac{\mathrm{dx}_{1}}{\mathrm{dt}}=\mathrm{T}_{1}, \\
& \frac{\mathrm{dx}{ }_{2}}{\mathrm{dt}}=\frac{\mathrm{S}_{2} \mathrm{PnH}(\mathrm{Pn})}{\mathrm{S}_{2}+\mathrm{x}_{2} / \mathrm{x}_{1}}+\mathrm{H}(-\mathrm{Pn}) \mathrm{Pn}-\left(1+\mathrm{r}_{\mathrm{g}}(\mathrm{t})\right) \mathrm{T}_{1}-\mathrm{T}_{2}-\mathrm{r}_{\mathrm{m}}(\mathrm{T}) \mathrm{T}_{2}, \\
& \frac{\mathrm{dx}}{\mathrm{dt}}=\mathrm{T}_{3}-\left(1+\mathrm{r}_{\mathrm{g}}\right)\left(\mathrm{T}_{4}+\mathrm{T}_{5}+\mathrm{T}_{6}\right)-\mathrm{r}_{\mathrm{m}}\left(\mathrm{T}_{\mathrm{r}}\right) \mathrm{x}_{6}-\mathrm{r}_{\mathrm{m}}(\mathrm{T})\left(\mathrm{x}_{3}+\mathrm{x}_{4}+\mathrm{x}_{5}\right), \\
& \frac{\mathrm{dx}}{\mathrm{dt}}=\mathrm{T}_{4}-\mathrm{r}_{\mathrm{m}}(\mathrm{T}) \mathrm{x}_{4} \mathrm{H}\left(\mathrm{a}_{4} \mathrm{x}_{4}{ }^{\alpha}-\mathrm{x}_{3}\right), \\
& \frac{\mathrm{dx} \mathrm{x}_{5}}{\mathrm{dt}}=\mathrm{T}_{5}-\mathrm{r}_{\mathrm{m}}(\mathrm{T}) \mathrm{x}_{5} \mathrm{H}\left(\mathrm{a}_{4} \mathrm{x}_{4}{ }^{\alpha}-\mathrm{x}_{3}\right),
\end{aligned}
$$

and

$$
\frac{d x_{6}}{d t}=T_{6}-r_{m}\left(T_{r}\right) x_{6} H\left(a_{4} x_{4}^{\alpha}-x_{3}\right),
$$

where $\mathrm{Pn}=$ net photosynthetic rate $\left(\mathrm{g} / \mathrm{m}^{2} / \mathrm{da}\right)$, 


$$
\begin{aligned}
& H(x)= \begin{cases}1 & x>0 \\
0 & x<0\end{cases} \\
& r_{g}=\text { growth respiration rate (function of temperature), } \\
& r_{m}=\text { maintenance respiration rate (function of temperature), }
\end{aligned}
$$

and $S_{2}, a_{4}$, and $\alpha$ are empirical parameters of growth. The equations for $\mathrm{T}_{1}$, $\mathrm{T}_{3}, \mathrm{~T}_{4}, \mathrm{~T}_{5}$, and $\mathrm{T}_{6}$ are:

$$
\begin{aligned}
& T_{1}=e_{1} x_{1}\left[k_{D} H\left(D_{L}-t\right)+k_{n}^{H}\left(t-D_{L}\right)\right] \frac{x_{2} / x_{1}}{c_{2}+x_{2} / x_{1}}\left(1-P_{\ell t d n s} x_{1} / a_{2} F_{0}\right), \\
& T_{3}=T_{\text {rns }} x_{2}\left[\frac{a_{1} x_{2}}{x_{1}+x_{2}}-\frac{b x_{3}}{x_{3}+x_{4}+x_{5}+x_{6}}\right] H\left[\frac{a_{1} x_{2}}{x_{1} x_{2}}-\frac{b x_{3}}{x_{3}+x_{4}+x_{5}+x_{6}}\right] H\left[\frac{x_{2}}{x_{1}+x_{2}}-s_{2}^{\prime}\right], \\
& \mathrm{T}_{4}=e_{4}^{\alpha x_{4} \alpha^{\prime}} H\left(x_{3}-a_{4} x_{4}^{\alpha}\right) \frac{x_{3}^{-a} x_{4}^{\alpha^{\prime}}}{b_{4}+x_{3}-a_{4} x_{4}^{\alpha^{\prime}}} \\
& T_{5}=H\left(\tau-\tau_{0}\right) e_{4} \beta x_{5} H\left(\tau_{1}-\tau\right) \text { H }\left(x_{3}-a_{4} x_{4}^{\alpha}\right) \text {, }
\end{aligned}
$$

and

$$
T_{6}=\frac{k}{T \Psi_{5} \mid} x_{6} \frac{x_{3}^{-a} x_{4}^{x^{\prime}}}{b_{4}+x_{3}-a_{4} x_{4}^{\alpha^{\prime}}} H\left(x_{3}-a_{4} x_{4}^{\alpha^{\prime}}\right)
$$

The parameters, $\mathrm{e}_{1}, \mathrm{~T}_{\mathrm{rns}}$, and $\mathrm{e}_{4}$, are empirical growth or translocation parameters with units of $\mathrm{da}^{-1}$, and $k_{D}, k_{n}, c_{2}, a_{1}, b, s_{2}, \alpha, \beta$, and $\alpha$ are empirical growth parameters of allocation and are unftless. $\tau$ is $a$ physiological time parameter, $\tau_{0}$ Initiates fruit growth (degree-da), and $\tau_{1}$ terminates fruit growth. $a_{4}$ and $b_{4}$ are in units of $\left(\mathrm{g} / \mathrm{m}^{2}\right)^{-\alpha^{\prime}}$ and $\mathrm{g} / \mathrm{m}^{2}$, respectively, $K$ is a root-growth parameter in units of bars da ${ }^{-1} \Psi_{S}$ is soil water potential. $D_{L}$ is the length of the day. $F_{0}$ is maximum leaf area Index allowed. $P_{\ell t d n s}$ is the number of $\mathrm{plants} / \mathrm{m}^{2}$ and $\mathrm{a}_{2}$ converts leaf biomass to leaf-area index with units $\mathrm{g} / \mathrm{m}^{2}$.

$\mathrm{P}_{\text {ltdns }}$ is the number of plants $/ \mathrm{m}^{2}$ and $a_{2}$ converts leaf biomass to leafarea index with units $\mathrm{g} / \mathrm{m}^{2}$.

A detailed model description is being prepared as an LLL report. This submodel has relied in part on the work of Shugart, et al., 6 Curry, 7,8 and Chen, et al. 9

Model Structure: Water Budget and Transpiration

This submodel calculates water stress and provides information to 


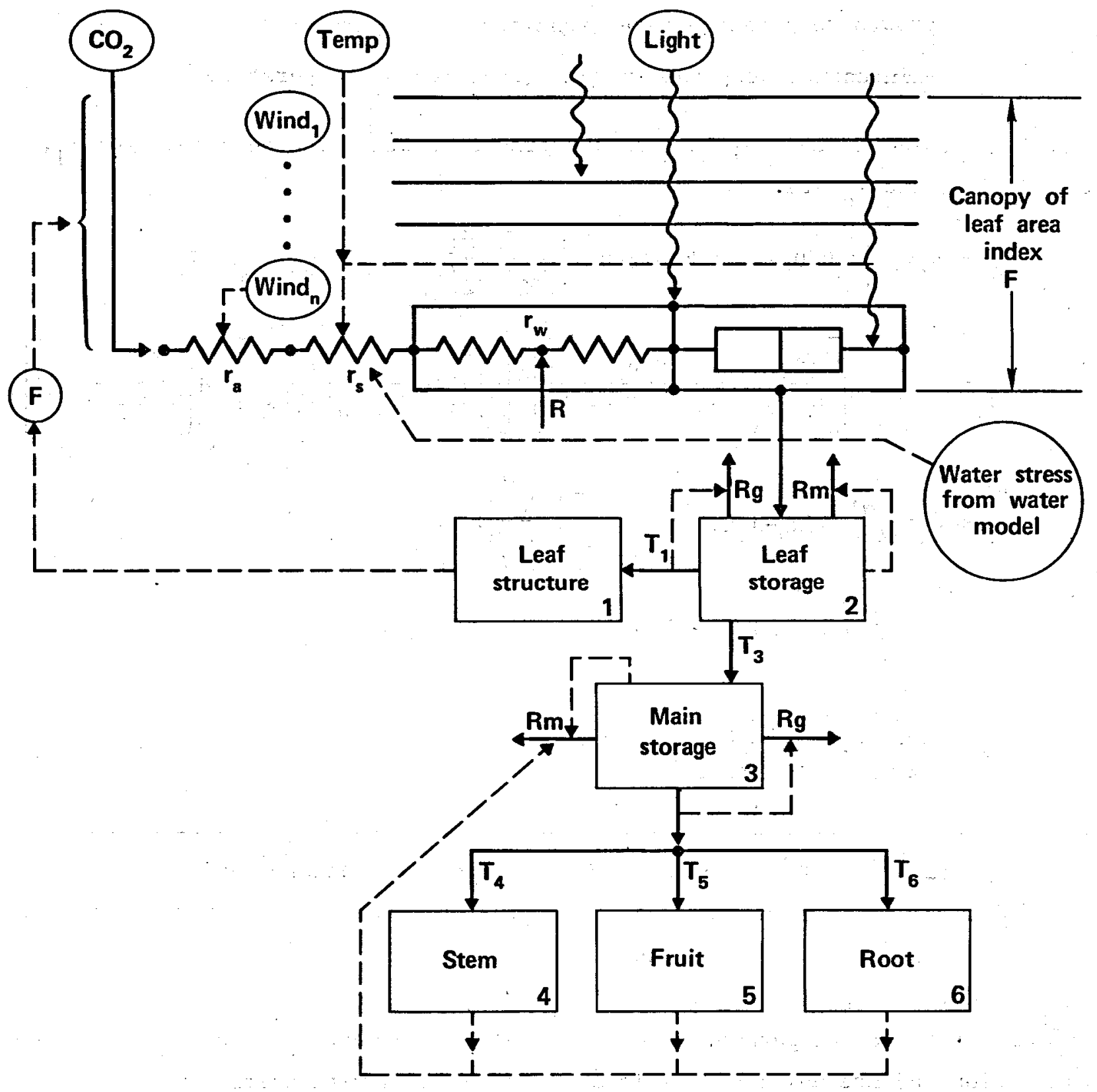

Fig. 1. Crop-growth-mode1 framework. The, environmental variables of light, wind, $\mathrm{CO}_{2}$ concentration, temperature, and precipitation determine behavior of plant properties. The model shown here traces the factors determining photosynthesis, respiration, and the allocation of photosynthate. The leaf submodel is in the center of the diagram with leaf resistances on the left and the biochemical model on the right. Solid lines are flow of photosynthate. Dashed lines are causal flow in information-controlling processes. 
the stomatal resistance in the photosynthesis submodel. We have Implemented a relatively simple model that we have modified from the work of Curry and Chen. 7,8 we are now implementing a more complex model that is based on the work of Goldstein and Mankin. ${ }^{10}$ The version adapted from Curry is shown in Fig. 2. A differential equation of the rate of change of soil-water content equalling the difference between precipitation rate and transpiration rate is integrated to determine soil-water content. Soll-water content determines soilwater potential, and soil-water potential determines stomatal resistance. Stomatal resistance along with climatalogical variables determines transpiration rate. A second, more

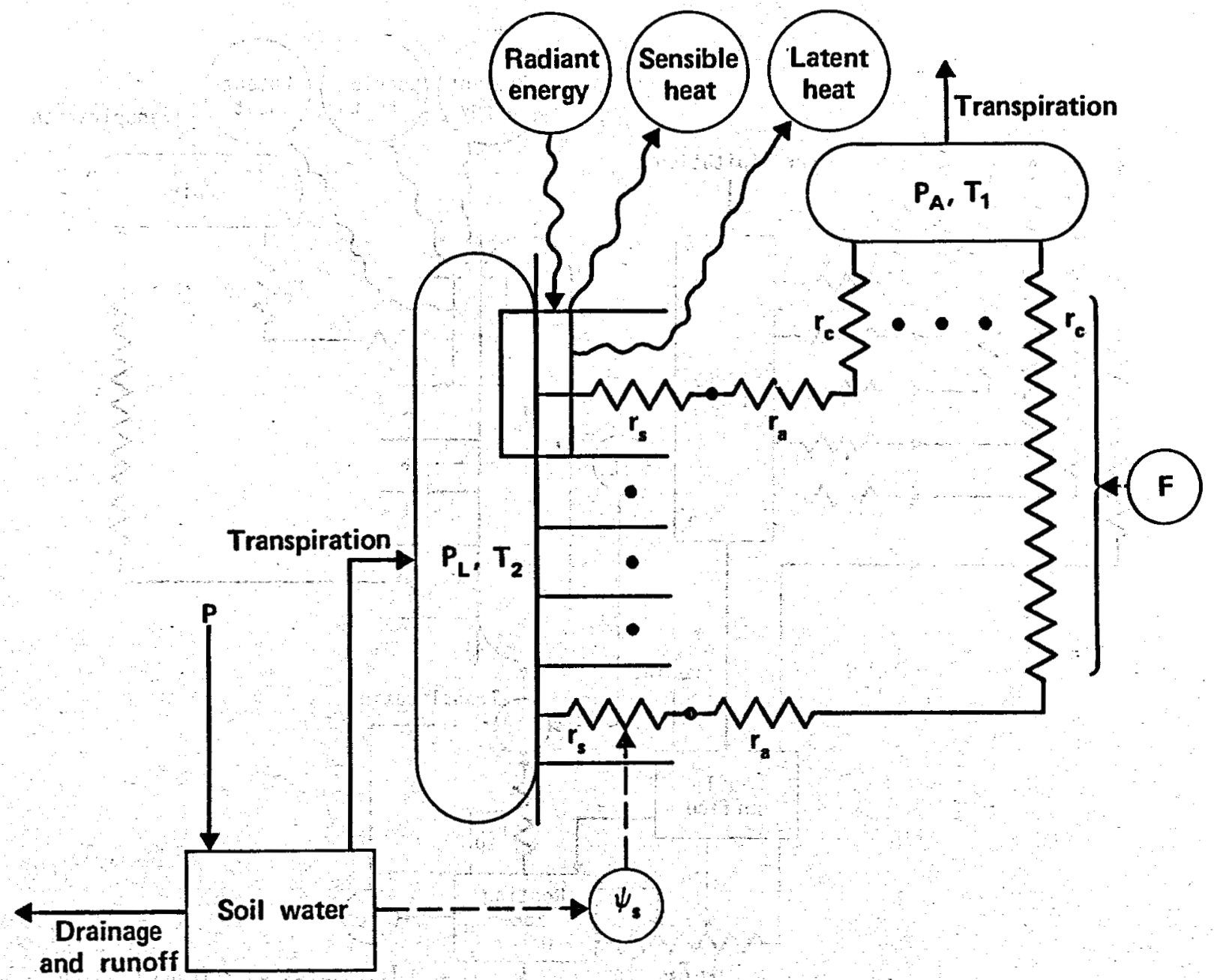

Fig. 2. Evapotranspiration model as a modifled version of a model by Curry. 7,8 Solid lines are flow of water. Dashed lines are causal flows of Information from one variable controlling another variable. Center portion is leaves wi th variables of temperature $T_{2}$ and water vapor pressure $P_{2}, F$ is leafarea index, which determines the number of canopy layers. Crooked lines are resistances to water-vapor flow. 
complex model is being implemented because of the inadequacy of the first model in determining stomatal resistance. Stomatal resistance is known to fluctuate during the day as the radiative load increases transpiration rates, which in turn increase plant-water stress. Hence the second model shown in Fig. 3 uses leaf-water potential to determine stomatal resistance. In this model, translocation from the soil is equated to transpiration to calculate leafwater potential, which is then used to calculate stomatal resistance. As before, the state variables are water contents in three storage compartments: canopy storage $x_{9}$, soilsurface zone storage $x_{8}$, and rootingzone storage $x_{7}$. The time derivative

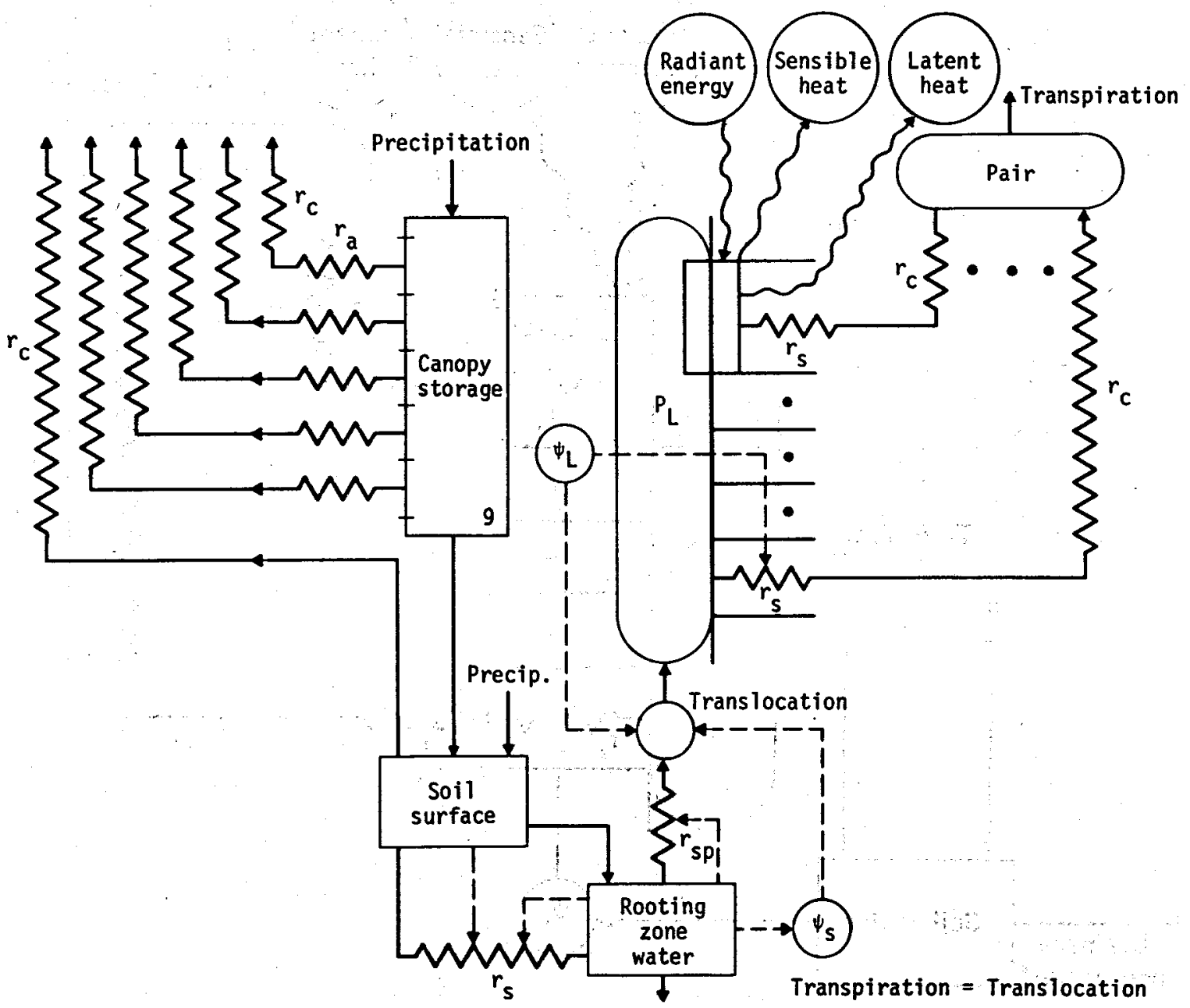

Fig. 3. Evapotranspiration model as a modified version of a model by Goldstein and Mankin. 10 Solid lines represent the flow of water. Dashed lines represent flow of information from one variable to another where the first controls the second. In this model, leaf potential $\Psi_{L}$ controls translocation and stomatal resistance, which in turn controls transpiration. Transpiration is set equal to translocation. 
of each compartment is equated to the difference between input and output rates.

A detailed description of these processes will be given in the LLL report in preparation.

Preliminary Example of Mode1.

Resu1ts

In Fig. 4, we show a typical output of the current version of the model in the case of no pollution. It is parameterized by corn data from Sinclatr, ${ }^{11}$ stewart, 12 and Curry and Chen. Respiration values for cotton (Thornley and Heskith) ${ }^{13}$ are used. In Fig. 5, we show the model output with a pollution level of $\mathrm{SO}_{2}$ at 10 ppm, and in Fig. 6 we show the output with a pollution level of $\mathrm{SO}_{2}$ at 50 . $\mathrm{ppm}$. The data to parameterize the pollution-effects function were taken from Bennet and $\mathrm{Hi} 11^{14}$ and are valid for barley and alfalfa. Notice the enhanced growth at $10 \mathrm{ppm}$ and the deleterious effects at $50 \mathrm{ppm}$.

Further Research and Modifications

The model needs developmental work in several areas. First of a11, pollution effects are handled at an empirical level and not a blochemical leve1. Second, the current section on water stress and stomatal control is currently being altered along the lines suggested above because the current version is unrealistic and inadequate. Third, the rootgrowth algorithm is giving results counter to experimental evidence on the effects of soll salinity on root growth.

Future plans in modeling pollutant effects on plant growth include the eventual incorporation of effects of nutrient levels on plant growth. This topic is crucial in understanding the growth-enhancing properties of some pollutants at low concentrations. Finally, this point raises the whole question of synergisms and antagonisms, whether between pollutants or between pollutants and nutrients. This problem Is fundamental to understanding the behavior of vegetative systems under pollutant stress. It is an area in which integrated research projects on energy technologies are uniquely capable of providing leadership by coupling sophisticated fieldresearch efforts and computer-modeling techniques.

Legal and Institutional Aspects of Water Management Alternatives

David W. Layton and James C. Wharton

Two major sources of cooling water for geothermal power plants in the Imperial Valley are imported Colorado River water and drainage water from irrigated agriculture contained in the Valley's rivers and drains. The use of those waters, however, is governed by a body of law that involves statutes and court decisions on the 


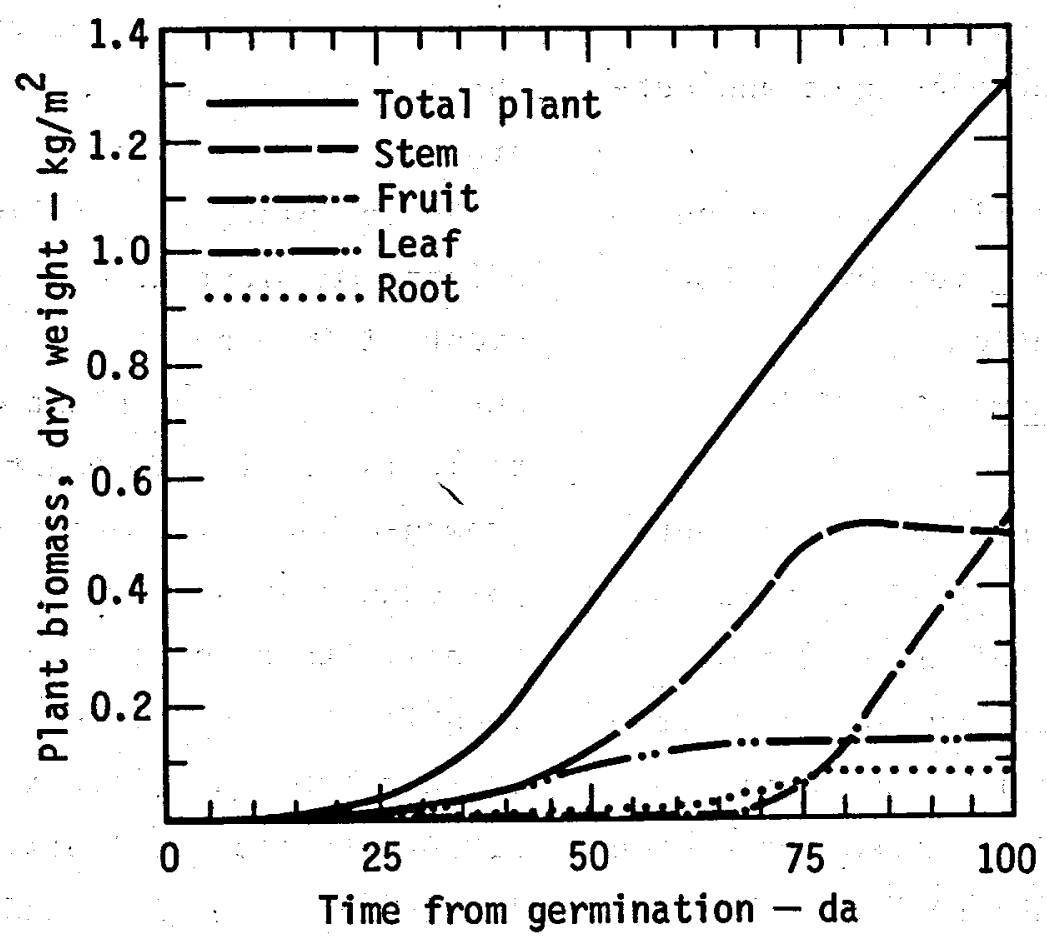

Fig. 4. Output of model for growth without pollution stress.

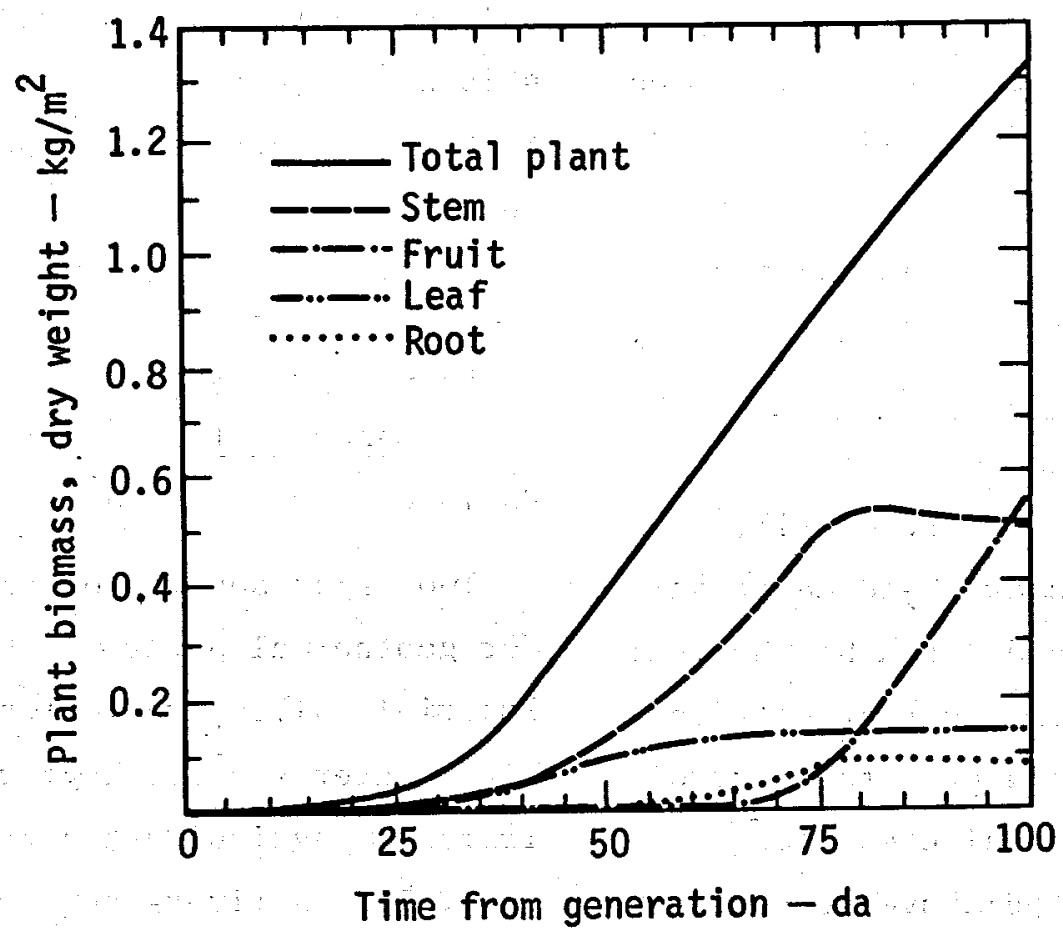

Fig. 5. Output of model for growth with a constant pollutant stress of $10 \mathrm{ppm} \mathrm{SO}_{2}$ with data for barley and alfalfa with stress effects. 


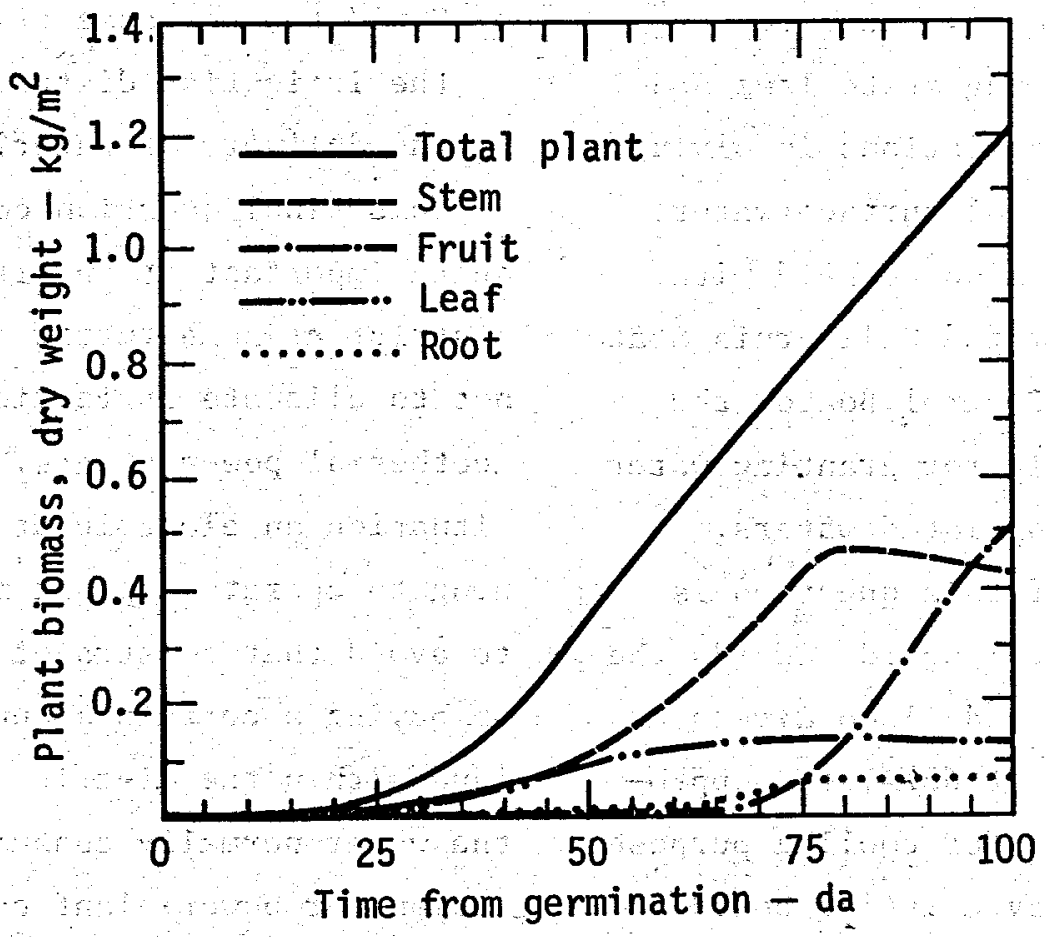

Fig. 6. Output of model for growth with a constant pollutant stress of $50 \mathrm{ppm} \mathrm{SO}$

state and federal leve1. A preliminary review of existing laws indicates that several questions need to be addressed to evaluate the avallability of cooling water from a legal point of view. Those questions revolve around laws affecting the appropriation of surface waters and the distribution of water to users within an Irrigation district. The specific questions being considered are as follows:

- How is Colorado River water allocated to California appropriators during times of both excess and reduced flows?

The answer to this question requires information related to the water rights of California users of Colorado River water and the statutes and court decisions controlling the allocation of river water. To date, background material has been acquired on water rights and on the 1964 decree of the U.S. Supreme Court concerning the appropriation of Colorado River water by Arizona and California. The relationship of the existing water rights to the court decree must now be defined. It is expected that relevant information can be obtained on that relationship from the colorado River Board of California.

- Is there public water in the New and Alamo Rivers? And if so, can it be appropriated for evaporativecooling devices? 
The second question requires an analysis of existing state laws and administrative regulations involving the appropriation of surface water. Discussions will also be held with staff working for the California State Water Resources Control Board, the agency responsible for granting water rights on unappropriated waters. Another aspect of this question is whether the control board regards the water in the New and Alamo Rivers as being fresh. If it does, the appropriation of water for cooling purposes may be hindered by existing board policy. 15

- What are the legal implications of using agricultural drainage waters in the Imperial Irrigation

\section{District?}

A review of past court decisions will probably provide the basic answers to apparent discrepancies in existing laws affecting drain waters.

It appears that under Section 20078 of the California State Water Code an irrigation district is empowered to salvage or recapture water for beneficial uses and presumably that water could be in drains. However, at least one court decision ${ }^{16}$ has ruled that the state has jurisdiction over unappropriated water in drains. That decision along with other relevant -court cases must be examined to determine the legal status of drain water in an irrigation district.
- Could the purchase of land within the irrigation district guarantee the delivery of water?

This final question could become quite important if the Irrigation district at some future time decided not to allocate irrigation water to geothermal power plants. In such a situation an electric utility planning to operate a plant might be able to avoid that constraint by leasing or buying a certain amount of farmland within the district and then use the water normally consumed in irrigation for power-plant cooling. Research on this particular question will again entail a review of present statutes and appropriate court decisions.

Comparison of the Effectiveness of Federal and State Geothermal Lease Laws

James C. Wharton

A preliminary study ${ }^{17}$ of the laws that pertain to the development of geothermal resources in the Imperial Valley was completed. The study describes federa1 statutes, federa1 licenses and permits, state geothermal lease statutes, state regulation of geothermal wells, and regulation of the geothermal resource. The federal law is primarily contained in the Geothermal Steam Act of 1970. ${ }^{18}$ This Act provides for geothermal leases and the use of associated geothermal 
steam resources underlying public

lands. The Secretary of the Interior is authorized to issue leases for the development of geothermal steam and the associated geothermal steam resources in much the same manner as he was authorized to lease land for development of their oil and gas deposits under the Minera1 Leasing Act of 1920 , as amended. 19 The definitions under the mineral leasing laws were amended to include geothermal resources:

"Mineral leasing laws shall mean the Geothermal Steam Act of 1970 which are amendatory of or supplementary to any of the foregoing Acts; Leasing Act minerals shall mean all minerals which are provided in the mineral leasing laws and all geotherma1 steam and assoclated geothermal resources which, upon the effective date of the Geothermal Steam Act of 1970, are provided in that Act to be disposed of thereunder ( 30 U.S. Code Section 530)."

The Secretary of the Interior may issue leases for the development and utilization of geothermal steam and associated geothermal resources in any national forest or other lands administered by the Department of Agriculture through the Forest Service, including public, withdrawn, and acquired lands, and in lands that have been conveyed by the United States subject to a reservation of the United States of the geothermal steam and associated geothermal resources therein. ${ }^{20}$ The definitions of geotherma1 lease, geothermal. steam, and associated geothermal resources are given in the Act. 18

Certain federal lands are exempted from geotherma1 1easing. Geothermal leases shall not be issued for lands administered in accordance with the Act of August 25, 1919, for 1ands within a national recreation area, for lands in a fish hatchery administered by the Secretary, wildlife refuge, wildlife range, game range, wildlife-management area, waterfowlproduction area, or for lands acquired or reserved for the protection and conservation of $f$ ish and wildlife that are threatened with extinction, for tribally or individually owned Indian trust or restricted lands, within or without the boundaries of Indian reservations. 21

Although the Secretary of the Interior has the power to lease lands that have been conveyed by the United States subject to a reservation of the mineral rights under Section 1002,20 this does not decide who owns the geothermal resource. Under Section 1020,22 the Secretary of the Interior may, upon finding that deve1opment of geothermal resources is imminent, report to the Attorney General, and the Attorney General is directed to institute an appropriate proceeding in the United States district court of the district in which 
such lands are located to quiet the title of the United States in the geothermal resource. In the event that the resource is reserved to the United States, their development may be enjoined until compliance with leasing requirements. Thus, Congress evaded the issue of the ownership of the geothermal resource and deferred it to the courts.

To further complicate the matter, the reservation of mineral rights to the United States may reserve only part of the geothermal resource and leave part of the resource in private hands. In a letter by the Deputy Solicitor, U.S. Department of the Interior, Edward Weinberg states that water has not been treated as a mineral in the public land laws. No statute has been passed by Congress that treats water as a mineral. Thus, if the geothermal resource is treated as water, it would not be reserved. On the other hand, any minerals connected with the geothermal steam would be subject to the mineral reservation. In the federal act, the geothermal resource is characterized as geothermal steam. Geothermal steam is essentially just subterranean water heated to a high temperature and would not be reserved to the United States, according to the Solicitor. Not all geothermal resource is geothermal steam.
In California the definition of geothermal resource that predates the Geothermal Steam Act is somewhat different than the federal characterization. Public Resources Code Section $6903^{23}$ defines geothermal resources as follows: "For purposes of this chapter, 'Geothermal Resources' sha11 mean the natural heat of the earth, the energy, in whatever form, below the surface of the earth present in, resulting from, or created by, or which may be extracted from, such natural heat, and all minerals in solution or other products obtained from naturally heated fluids, brines, associated gases and steam, in whatever form, found below the surface of the earth, but excluding oil, hydrocarbon gas or other hydrocarbon gas or other hydrocarbon substance." Since the definition of the geothermal resource includes the energy "in, resulting from, or created by, or which may be extracted from," heat, this definition covers energy in the form of pressure as well as heat. This broad-based definition also clearly includes hot-rock massifs and geopressured fluids because of the particular language used. Solute minerals and other substances are part of the resource, but the heatexchange mediums themselves appear to be excluded. The language limits the resource to energy, heat and pressure, and minerals and does not 
include the transfer medium unless "other products" is interpreted to mean and include the heat-transfer medium. The California law makes clear distinctions between wells for water, geothermal energy, and oil and gas. Section $3742.2^{24}$ provides for certificates of primary purpose that create a rebuttable presumption of absolute title to geothermal resources from wells that are primarily for the purpose of producing geothermal resources and not for the purpose of producing water usable for domestic or irrigation purposes. Furthermore, Division 7 of the California Water Code Section $13710^{25}$ declares that water wells do not include oil and gas wells, or geothermal we1ls. This seems to settle the matter that under California law geothermal resources are not water resources, which is completely the opposite of the federal situation discussed above.

In reviewing the cases under the National Environmenta1 Policy Act (NEPA), 42 U.S. Code Sections 4321 et seg., 26 it is clear that environmental considerations must be taken into account in the development of the geothermal resource. On the other hand, as long as the procedural requirements of the Act are met, NEPA should not be a particularly. egregious impediment to geothermal development. As the study of substantive rights under NEPA shows, it is only the rare case of grave environmental harm where a project cannot proceed under any circumstances. 27,28 However, from the draft report of the Department of the Interior, it is expected that geothermal power development will create less pollution than energy production from hydrocarbon conversion or atomic conversion. 29

The State of California has passed several laws and regulations that pertain to geothermal-resource deve1opment. The State Energy Resources Conservation and Development Comission has exclusive power to certify all sites and related facilities. The Energy Commission must obtain comments from local, regional, state, and federal agencies. Power plants up to 100 megawatts may be exempted from Commission requirements. 30 However, this has been limited to special-use situations and probably is not available as an exception for operation of $a$ power plant by a public utility to supply public power. On the other hand, the Code only applies to plants over 50 megawatts. 31

Thermal power plant means any stationary or floating electrical generating facility using any source of thermal energy with a generating capacity of 50 megawatts or more and any facilities appurtenant thereto.

The final report on the comparison of the federal and state laws on 
geothermal power will include case law that has arisen on the question of ownership of the geothermal resource when there has been a reservation of mineral rights. Although not mentioned above but discussed in the preliminary report, UCRL-52121, 17 the definition of known geothermal resource is not the same in the state and federal statutes. In addition, California statutes use the term in two different senses. Since the designation of an area as a KGRA has special consequences under the bidding requirements, these differences will be compared and discussed.

Atmospheric Model Modification for Imperial Valley

Donald L. Ermak

The purpose of this task is to modify and improve existing atmospheric models for air-quality assessment of the LLL scenarios for geothermal development in Imperial Valley. The major pollutant of concern resulting from geothermal operations in Imperial valley is hydrogen sulfide. It is aesthetically unpleasant because of its unpleasant odor even at very low concentrations, has adverse effects upon agriculture at moderate concentrations ( $>75 \mathrm{ppm})$, and is toxic at high concentrations (not expected from geothermal operations). It is also believed to undergo chemical transformation to sulfur dioxide, which in turn is chemically transformed to sulfate compounds that have adverse human health effects. Other geothermal pollutants of concern include ammonia, particles, and trace elements (especially boron).

Initial air-quality assessments will use an LLL-modified version of the EPA C1imatological Dispersion Model (CDM) ${ }^{32}$ The model calculates long-term (seasonal or annual) average-pollutant concentrations at the ground level using average emission rates and a joint frequency distribution of wind direction, wind speed, and atmospheric stability. CDM is based upon the standard Gaussian plume model and uses the Pasquill dispersion parameters. The original model does not consider chemical transformations to secondary or tertiary compounds, deposition onto ground surfaces, gravitational settling in the case of particles, and multiple sources.

To treat the pollutants expected from the Imperial Valley geothermal operations, the additional atmospheric effects discussed above must be included in the model. During the period covered by this report, several of these improvements have been added to the model. The code has been extended to handle first-order chemical transformation chains of up to three species, $A \rightarrow B \rightarrow C$. Using the source depletion approach, the 
effect of ground deposition is included for each species. In the case of particles, a non-Gaussian plume model ${ }^{33}$ has been developed to include the effects of gravitational settling. In addition to calculating the ground level concentration, the improved model also calculates the deposition flux, the total grounddeposition rate within the study region, and the total rate at which pollutants are transported out of the study region by the wind. Present and future efforts on this model include: improving the treatment of inversion layers, extending the code to handle multiple pollutant sources, and improving the graphics-display package.

More sophisticated atmosphericpollutant-transport models can be used when detailed meteorological data is available (for example, consecutive hourly meteorological measurements for periods of a year). Two modeling approaches are being considered for this situation. The first approach requires extensive modification of the LLL three-dimensional particle in cell code c $^{34}$ and the twodimensional coupled transport-kinetics $\operatorname{code}^{35}$ to simulate extended periods of time rather than short periods (hours to days) for which they are presently applicable. The second approach is to use a trajectory model such as that developed at the Brookhaven
National Laboratory. 36 Trajectory models are currently in use for longterm assessments. Both modeling approaches require a wind-field model $^{37}$ to generate time and spatially varying wind fields from meteorological data taken at fixed locations.

\section{Water Resource Impacts of Geothermal}

\section{Facilities}

David W. Layton

Geothermal power plants suffer from thermal inefficiencies caused by reservolr temperatures that are generally below $300^{\circ} \mathrm{C}\left(572^{\circ} \mathrm{F}\right)$. As a consequence, substantial amounts of heat must be rejected for each kilowatt-hour of electricity generated. And to effectively remove that waste heat, large amounts of cooling water will be required for evaporative cooling devices like mechanical-draft wet-cooling towers and spray ponds. Other cooling technologies such as wet-dry towers or even dry towers could significantly reduce water use, but only at great expense. A recent study ${ }^{38}$ has shown that for intermediate-load coalfired power plants in the Yellowstone River Basin dry-cooling towers became economically feasible when the price of water reached about $\$ 750$ per acrefoot. Currently the water rate charged by the Imperial Irrigation District is just $\$ 4.75$ per acre-foot, far below the level that would prompt 
the use of dry-cooling technologies.

To predict the availability of surface water for future geothermal facilities, regression analysis will be used to define the historic relationship between cropping patterns and water use in the valley. That relationship will then serve as the basis for analyzing the effect potential cropping patterns and irrigation practices will have on irrigation requirements and waste water flows. Evapotranspiration estimates of cropping patterns will also be calculated to supplement the regression analysis. Once future water supply conditions are specified, the changes in quantity and quality (salinity) of water flowing in the New and Alamo Rivers will be determined using water consumption rates of different geothermal development scenarios.

IVEP Data-Base Plan, Data Base, and Data Management

Robert A. Nyholm

Data acquisition, exchange, display, and management were recognized as integral elements of the Imperial Valley Environmental Project during its initial stages. To develop a data-base system, several tasks have been established to:

- Develop a data-base plan,

- Develop a mass-storage capability - investigate and assess existing data-base-management systems,

- Coordinate data input and exchange,

- Fit existing associated data bases to the IVEP data base,

- Assist IVEP Integrated Assessment staff with data acquisition, formating, and display, and

- Investigate existing geocoding systems. IVEP Data-Base Plan

An analysis of the data-recording, formating, and usage problems began with a thorough evaluation of the needs of all IVEP survey programs and user groups. Estimates were made of:

- Perceivable data types,

- Volume of data,

- Rate of data updating and modification,

- Anticipated use (analysis, modeling, inquiry, report generation),

- Level of information retrieval, and

- Relationship of other (non-LLL) data bases.

An initial data-base plan was then conceived and tested, using the Water Quality Survey Program as a source of data. After several modifications, the plan was implemented by all survey programs.

The system is designed to provide a consistent and concise vehicle by which information is to be reported for inclusion into the project database network. Currently, the scheme 
has the capability of retaining the following information:

- Sample identification (official unique number)

- Sample-aliquot number,

- Date of sample collection,

- Time of sample collection,

- Latitude-1ongitude (degrees and decimal minutes),

- Sampling level (i.e, depth, tower level, altitude in decimal meters,

- Location of sampling by map site (grid coordinates),

- Location of sampling by narration (i.e., word description),

- Type of sample (1.e, water, soil, vegetation, bird, aquatic, etc.),

- Sample key words,

- Narrative comments (pertaining to sample),

- Parameters analyzed,

- Measurement (i.e., analytical result),

- Assoclated percent error,

- Method of analysis,

- Group that performed analysis (1aboratory and laboratory group),

- Unit in which data is reported,

- Validity indicator,

- Narrative remark (pertalning to parameter),

- Missing data flag,

- Non-detectable data flag with detection Ilmit, and

- Narrative type data.

These items of data will normally be input via punched cards. Alternate modes of entry are from teletypewriter and magnetic-tape card-image files.

Data-entry forms have been developed to help facilitate input. Figure 7 is an example. These forms are particularly useful to the efficient experimenter who is collecting field samples. Plans are currently being made to provide him with a bound notebook of forms so that data forms are filled out in the field and other field notebooks may be eliminated.

Referring to Fig. 7, there are four defined card types. CARD TYPE is a field to be used by the network; it will inform the system of the kind of information to expect. It will also be used to sort and sequence punched cards should they accidentally be dropped. Data-field description proceeds by CARD TYPE series as follows:

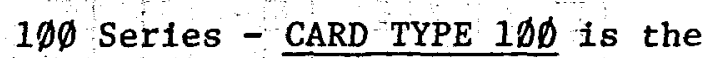

Header/Description card. It defines all fixed information. IDENTIFIER: The sample IDENTIFIER is a seven character field made up of six SAMPLE NUMBER characters and one SAMPLE ALIQUOT NUMBER character. This identifier must be unique to the project data base (so that program data bases may be merged without conflicting identifiers). It is the link to all associated sample information. 
Recorded By:

Group:

Date:

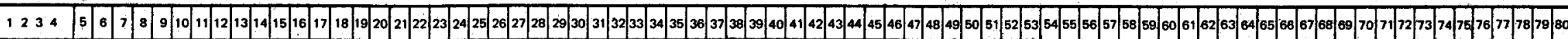

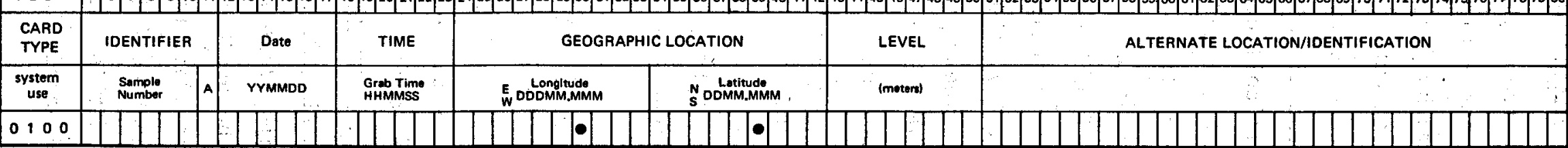

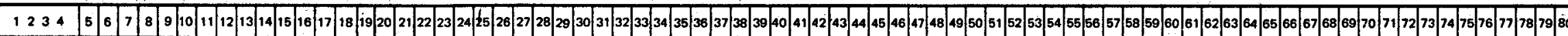

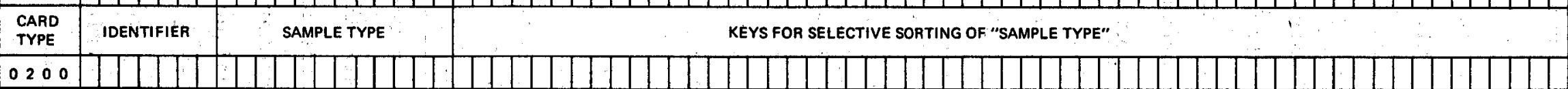

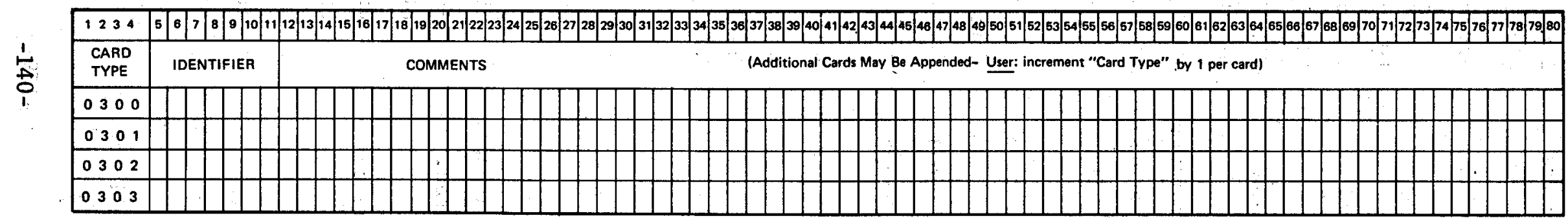

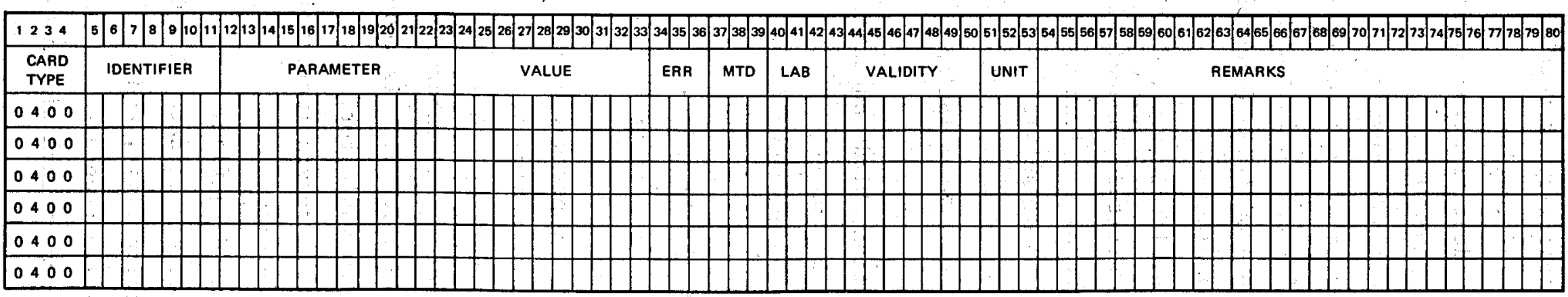

Fig. 7. IVEP data-entry form. 
To samples that are later separated for analysis (i.e., dissec-

tion, water samples sent to separate laboratories for analysis, etc.) a SAMPLE ALIQUOT NUMBER Is assigned.

DATE: The date field is a selfexplanatory data field it is the date of sample collection recorded as YYMMDD.

TIME: The time field is similar to the date field; it is the local time of sample collection recorded as HHMMSS.

GEOGRAPHIC LOCATION is recorded as Lat1tude/Longitude (degrees and decimal minutes) or by an a1ternate Survey Program Fixed Site Codé. The code must be found somewhere on the Type $1 \emptyset \emptyset$ card whether it be embedded in the IDENTIFIER or written separately in the ALTERNATE LOCATION field. Code definition is discussed below. LEVEL is the depth/aititude indicator recorded as decimal meters referenced to the surface elevation. $2 \phi \emptyset$ Serfes - CARD TYPE $2 \phi \emptyset$ is the sample Type/Keyword card. To date, 12 IVEP SAMPLE TYPES are defined. These include: Gas, Meteorologic, Social, Economic, Water, Soil, Sediment, Vegetation, Mamma1, Bird, Aquatic, and other. KEYWORDS further define SAMPLE TYPE. The keywords are later to be used for a selective search on Sample Type whereas: SAMPLE TYPE is used to selectively search on the IVEP Data Base. Keywords or phrases - of up to but not to exceed 56 characters are allowable provided they contain no blanks, commas, or semicolons. It is by any one or combination of these three characters that keywords are to be separated. Multiple Type $2 \emptyset \emptyset$ cards are permissible.

$3 \emptyset \emptyset$ Series - CARD TYPE $3 \emptyset \emptyset$ SERIES is reserved for narrative COMERTS. There can be up to $1 \emptyset \emptyset$ Comment Cards per IDENTIFIER number. Sequencing of the comment cards is controlled by the CARD TYPE field number ( $3 \emptyset \emptyset$ through 399 ). Again IDENTIFIER serves as the sample link.

$40 \emptyset$ Series - A11 analytical results are to be reported on the $4 \emptyset \emptyset$ Type data card. Narrative-type data may also be reported here. PARAIETER: The parameter to be reported is identified in Columns 12 through 23 . The entry may be written anywhere within the confines of the fleld. Parametric synonyms may be entered Instead of the parameter. This capability will prove particulariy useful for short-hand notation when recording trace-element constituents. Parameter and synonym definitions will be discussed below. 
VALUE: Numerical results of analysis are reported anywhere within Columns 24 to 33 . The accepted format is either $F$ or $E$, that is to say, the number "1234" is entered as 1234. or 1.234E3. Note that both formats demand a decimal to be written. If for some reason a parameter is to be reported but its numerical value is unknown, a question mark ? is entered in the VALUE field. For parameters that give narrative results, the alpha string is written in the REMARIS field (Columns 54 through $8 \emptyset$ ) as will be explained below.

ERROR: Percent error of analysis is reported in Columns 34 through 36. Accepted format here is $\mathbf{I}$ or F; i.e., a $1 \emptyset \%$ error is reported

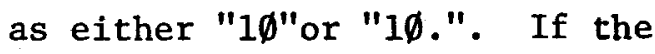
percent error is truly not known, a triple question mark ??? is entered in the field. If percent error has no meaning or is not applicable, a triple asterisk *** is entered. This is particularily convenient for narrative-data recordings. If a parameter is found to be below the minimum detectable limit, NDL is entered for the percent error and the minimum detectable limit is entered for VALUE.

METHOD: The method by which VALUE was determined is reported in
Columns 37 through 39. A table of allowable codes will be discussed below. For data of the narrative type, a triple asterisk *** is entered in the field.

LABORATORY: The laboratory responsible for VALUE is entered in Columns $4 \emptyset$ through 42. Again, a code table will be defined below. VALIDITY: Columns 43 through $5 \emptyset$ are to remain blank while reporting data. During preprocessing, all parametric data will be initially assigned an unverified indicator $N$ in Column 43 and category indicator $G$ in Column 44 with the date defined in Columns 45 through $5 \emptyset$ in the YYMMDD format. When reviewed, verified, and released by the originator, the indicators will be changed to $\mathrm{Y}$ and, $P$ or $F$, respectively. The abbreviations are - verification: N-no, Y-yes; categorization: Gfirst guess, P-preliminary, F-final.

UNIT: Allowable unit codes as they are to appear in Columns 51 through 53 are tabulated and discussed below. Non-numeric information receives a triple asterisk *** or NUN as an assigned unit.

REMARKS: Pertinent remarks concerning PARAMETER are made in Columns 54 through $8 \emptyset$. Additional comments may be made on Type $3 \emptyset \emptyset$ Series cards if necessary. Non- 
numeric information is reported in this field also - VALUE must then be left blank.

\section{IVEP Data Base}

To initiate the data-base plan, each survey program was first assigned an alpha character for identification (see Table 1). Subsequent data are then reported by a sample number beginning with that character. Hence, a block of sample numbers were allocated for the duration of IVEP for each survey program. Program leaders are responsible for distribution of these block numbers.

Six code files (computer-code tables) were developed. Table 2 outlines the format of these six files. The current contents of each file are in Tables 3 through 8 .

Table 3 is the fixed-site-code file; it relates each survey program's fixed-site code to a specific latitude, longitude, and geographic area reported by township, range, section, and quarter section whenever applicable. Narrative definition is also provided. The first column indicates for which survey program the code is defined. The second column is the number of samples (tally) that have the same site origin. Columns 4 through 7 define the associated latitude, longitude, township/range, and narrative description, respectively.

Similarily, Table 4 is the keywordscode file; Table 5 the parameter-code file. Column description is defined at the head of each listing.

Tables 6 through 8 are the analytical method-, laboratory-ofanalysis-, and unit-code file listings. An asterisk * Implies that the code is used by all survey programs. Again column description is defined at the file head.

Table 1. IVEP survey-program Identifiers.

\section{Code}

$A=$ LLL-IVEP Air Quality Program

$\mathrm{E}=$ State electrical energy data

$H=$ LLL Health Effects Program

$M=$ IVEP miscellaneous data bases

$S=$ LLL IVEP Socioeconomic Program

$T=$ Reserved for test-data sets

$\mathrm{V}=$ LLL-IVEP Ecosystems Program

$W=$ LLL=IVEP Water Quality Program
Responsible individual

P. Gudiksen

C. Hall

L. Anspaugh

R. Nyholm

C. Hall

R. Nyholm

J. Shinn

K. Pimentel 
Table 2. IVEP code formats (80-column punched-card image)

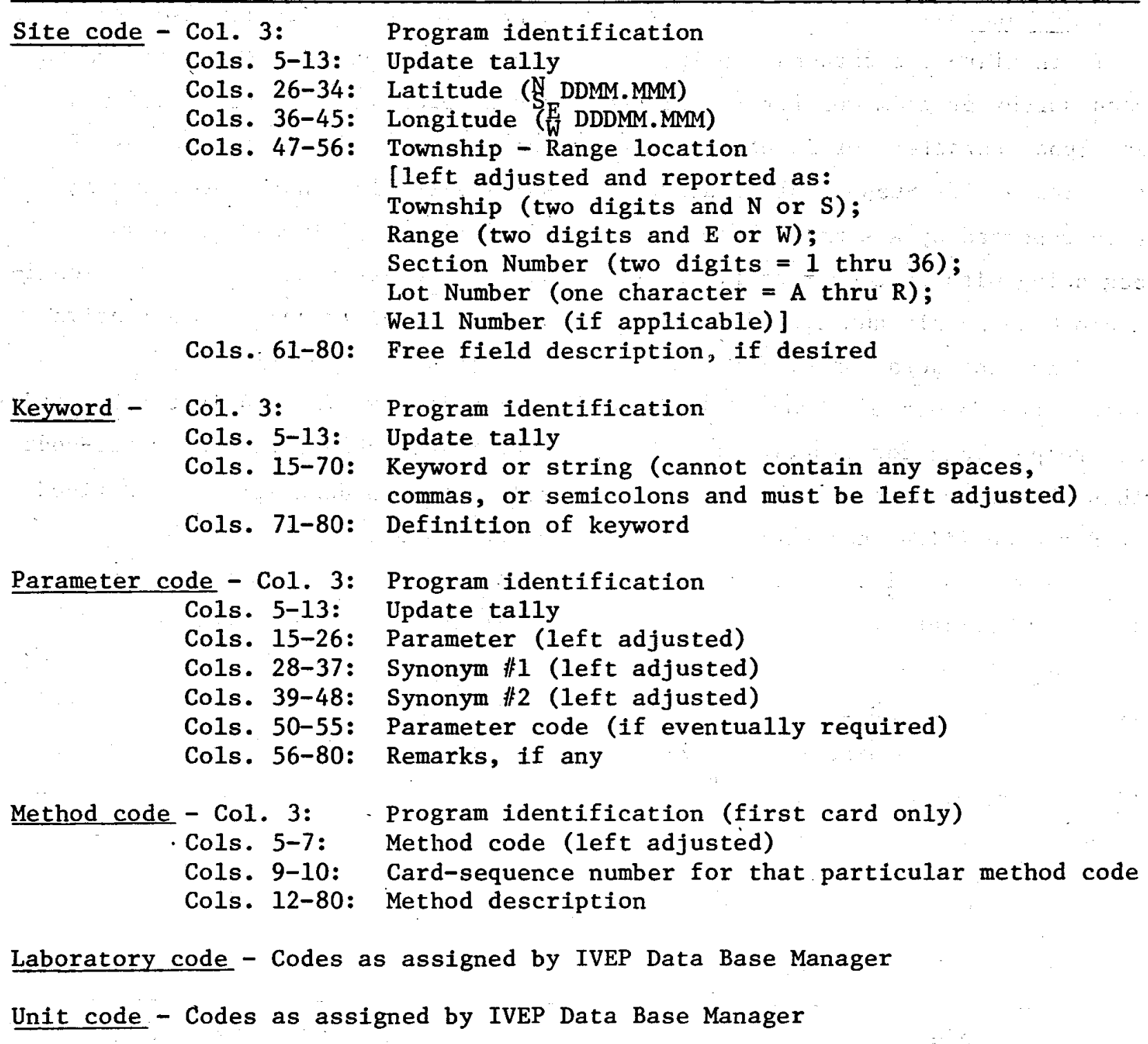

Each of the above files may be updated or appended at any time. Additional survey-program identifiers may be affixed as required.

As noted above, the code files have been developed for indicative information. Each is input to a Fortrancomputer program (preprocessor) that performs extensive error checking and sorts input-data files. All detected errors generate messages to an output file. Code-file tallies are updated when no apparent errors exist. Column one of the output-file-data line indicates the status of that line. A " $C$ " implies that the line has been processed and is presumed to be correct. An "E" means an error exists, and an 
Table 3. IVEP site-code file.

$(4,1 \cdot 200)$. क की

PAGE

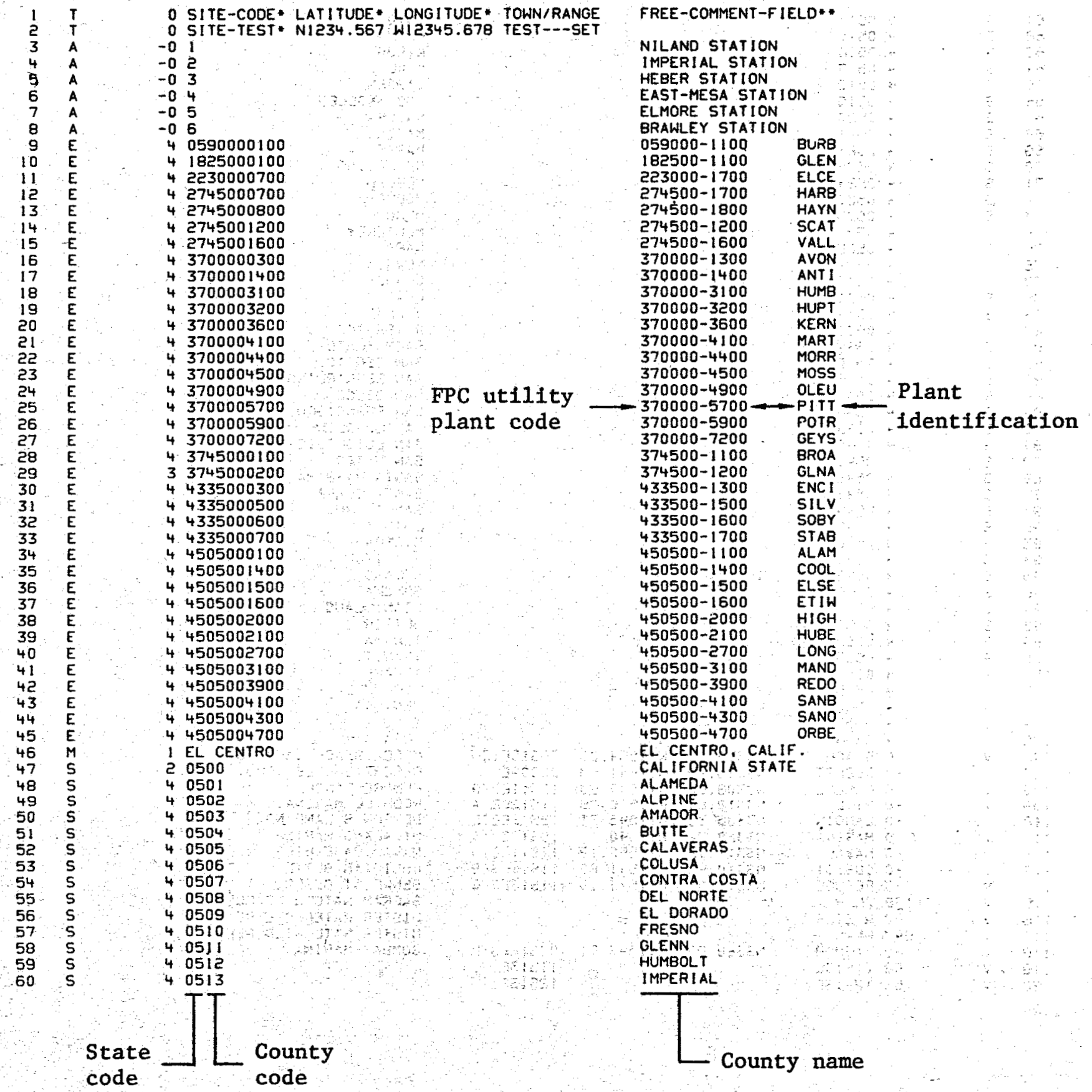


Table 3. (Continued)

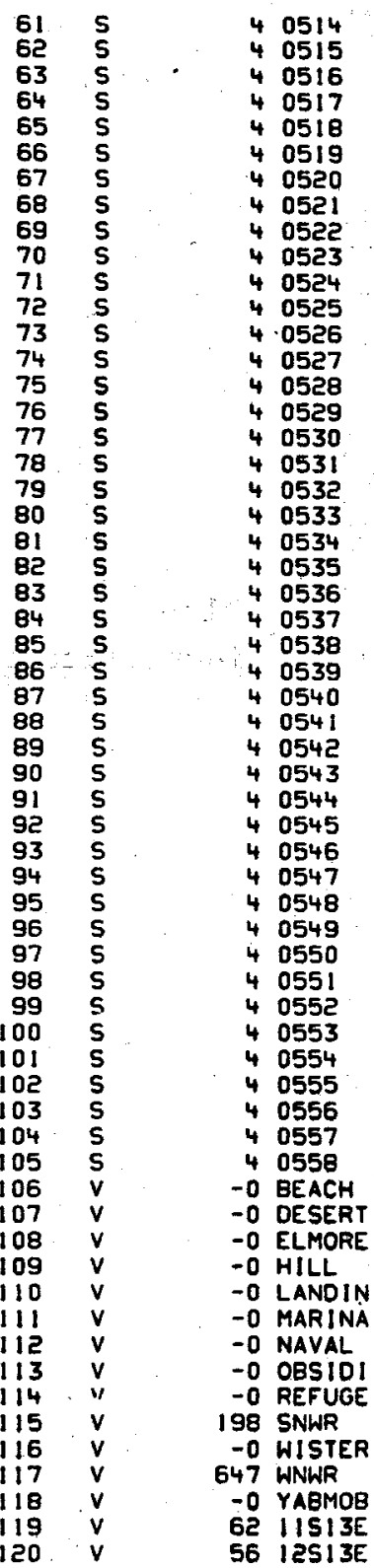

\begin{tabular}{|c|c|c|}
\hline $\begin{array}{l}\text { N3329.23 } \\
\text { N3323.92 } \\
\text { N3308.60 } \\
\text { N3312.64 } \\
\text { N3306.36 } \\
\text { N3320. } \\
\text { N3311..72 } \\
\text { N3310.49 } \\
\text { N331 } 1.01\end{array}$ & $\begin{array}{l}\text { W1 } 1554.09 \\
\text { WI } 1501.59 \\
\text { WI } 1547.60 \\
\text { WI } 1536.75 \\
\text { WI } 1545.21 \\
\text { WI } 1540.10 \\
\text { WI } 1550.12 \\
\text { WI } 1541.82 \\
\text { WI } 1542.19\end{array}$ & 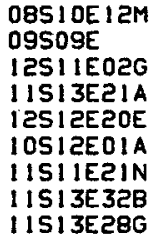 \\
\hline N3320.85 & W11543.91 & $\begin{array}{l}\text { 09SI2E 33M } \\
11513 E \\
12 S 13 E\end{array}$ \\
\hline
\end{tabular}

PAGE

INYO

KERN

KINGS

LAKE

LASSEN

LOS ANGELES

MADERA

MARIN

MARIPOSA

MENDOCINO

MERCED

MODOC

MONO

MONTEREY

NAPA

NEVADA

ORANGE

PLACER

PLUMAS

RIVERSIDE

SACRAMENTO

SAN BENITO

SAN BERNAROINO

SAN DIECO

SAN FRANCISCO

SAN JOAOUIN

SAN LUIS OBISBO

SAN MATEO

SANTA BARBARA

SANTA CLARA

SANTA CRUZ

SHASTA

SIERRA

SISKIYOU

SOLANO

SONOMA

STANISLAUS

SUTTER

TEHAMA

TR:NITY

TULARE

TUOLUMNE

VENTURA

YOLO

YUBA

MECCA BEACH CAMPGRD

DESERT SHORES (RMJ)

ELMORE RANCH

REDHILL MARINA

BENSON'S LANDING

NILALAND MARINA

NAVAL BASE PIER

OBSIDIAN BUTTE

SSNWF AT OBSER. PT

SACRAM NATL WILO REF

WISTER WATERFOWL RE

WISTER NATL WILD REF BOMBAY MARINA 
Table 3. (Continued)

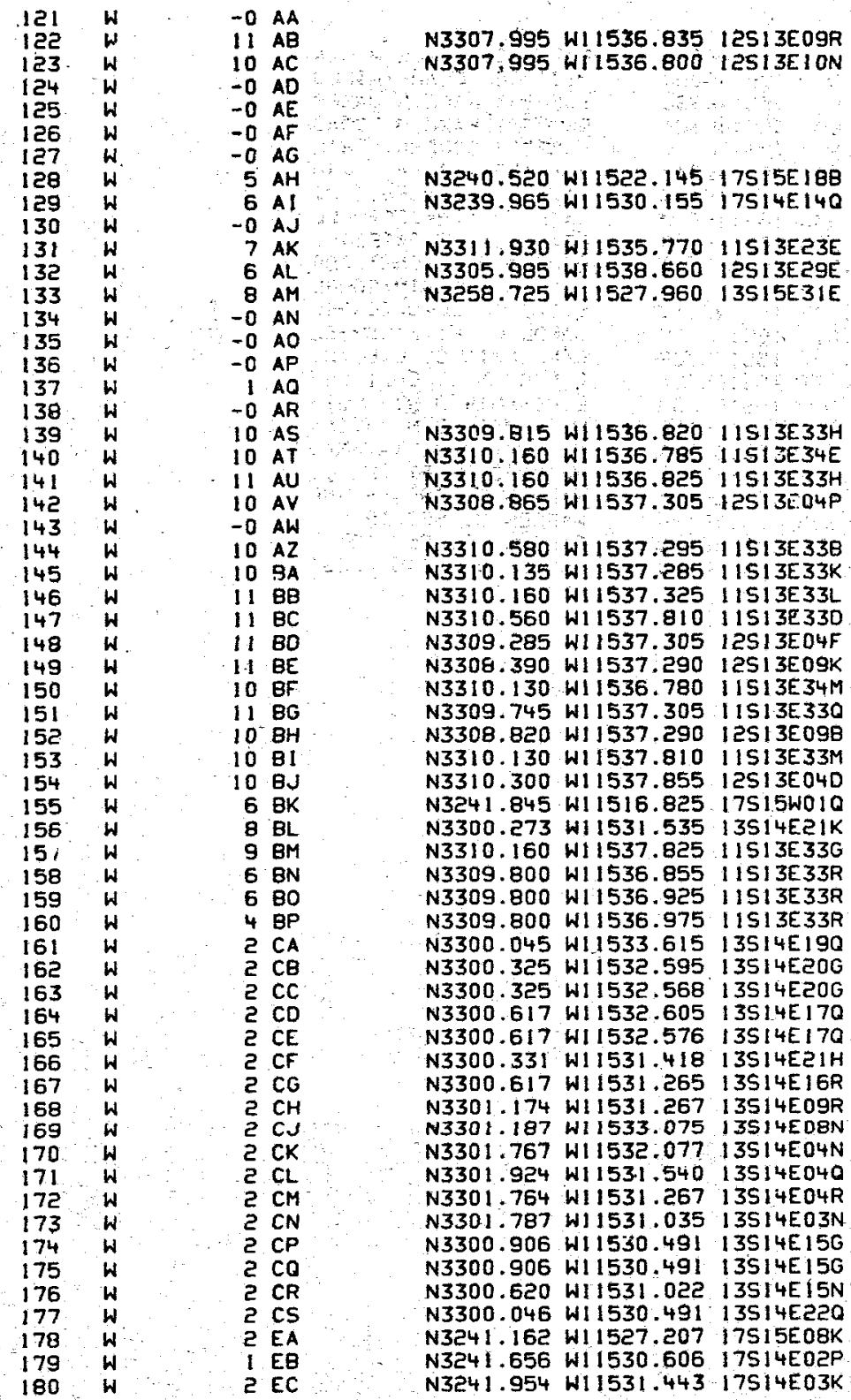

CANAL, VAIL 4 /VAILYA

VAIL4 D: GENTRY/YOUN

ALAMO R. BORDER

NEW R. BORDER

ALOMO R, GARST RD BR NEW R. LACK RD BR. ALAMO R. SR78 E BRAW

VAIL 4 C GENTRY/FOSS VAIL4 D. GENTRY/MCKE VAIL4 C. GENTRY/MCKE VAIL4A D. BOYLE/LIN

DRAIN, PUMICE IVAIL4A SUMPG BOYLE/MCKENDRY VAIL $4 A$ C. BOYLE/MCKE SUMP45 SEVERE/MCKEND SUMP I 16 BOYLE/KUNS

SUMPI2O BOYLE S LIND SUMP15 GENTRY/MCKEN VAIL4A D. BOYLE/FOSS SUMPBE BOYLE/LINDSEY SUMP42 SEVERE/KUNS

SUMP4 3 SEVERE/FOSS

CANAL. EAST HIGHLINE NEW R. SRIIII N BRAWL VAIL $4 A$ D. BOYLE/MCKE ERDA/SDGE SET POND

ERDA/SDGE SPRAY POND ERDA/SDGE BRINE POND SPRUCE C. BRANDT IFRE SUMPE38 HOV S ANDRE SPRUCE 1 D. HOV,S AND SUMP89 HOVLEY/ANDRE SPRUCE 3 D. HOVL / ANDR SPRUCE 1 D. NEAR NEW SPRUCE3 D. NEAR NEW SPRUCES D. NEAR NEW SPRUCES D. . SMI W HOV SPRUCES C. SPILL

NEH R IIIRR N RUTHE BEST D. RUTH. BY NEW ROCKWOOD C. RUTH/JEF SUMP 192 BEST, N WARD BEST D. BEST, N WARD LIVESLEY $D$. AT SEW P BEST C. BEST/SHANK CENT. MAIN C. OY RITT BEECH C. COLE/PRUETT SUMPI08 WARE, N COLE 
Table 3. (Continued)

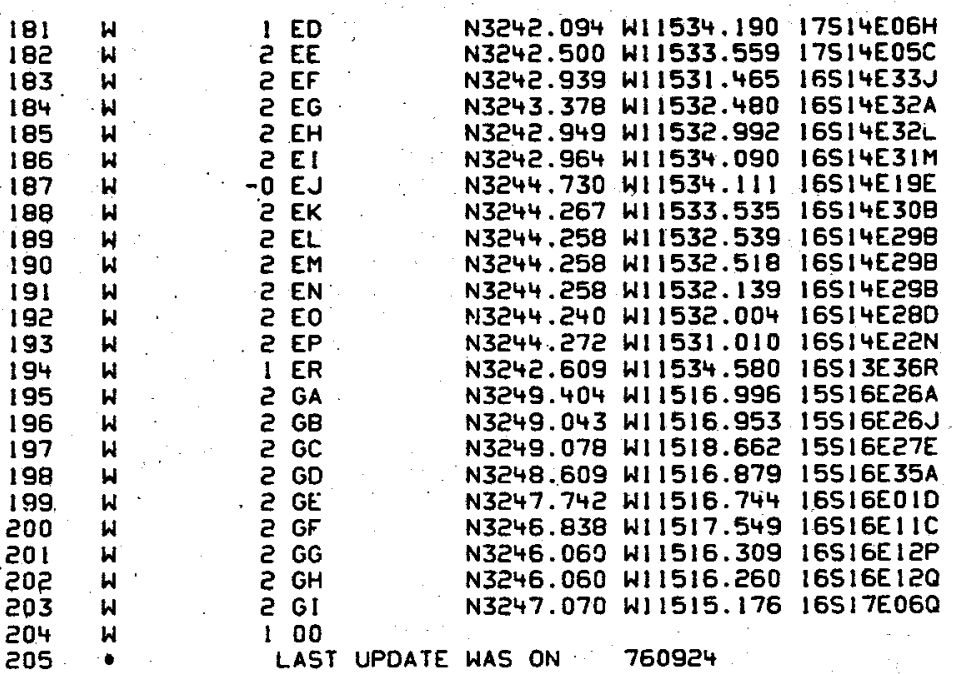

BEECH C. SPILL W CLA BEECH D. CLARK/WILLO SUMP273 WARE,N JASPR SUMP32I FAWC.H DOGWD SUMP397 CORFMN,N WIL SUMP I 37 W CLRK,S WAH DATE D. E LABRU,S MC DATE C. CLRK/CORRELL DRAIN DATE3/DATE3A

DGWDLAT2 C. FNWT/COR SUMP88 FRNSWTH/CORRL DOGWD C. DGWD/CORREL DAFDL C. PITZ/CORREL CENT.MAIN C. LABR/WI E. HIGHLN C. EHLIGDRP E.HGHLN14 D.BY EHL 14 HLTVLMAIN D.N KAVANA HLTVLMAIN D. KaVANAU HLTVLEC D. BY EHL 11 WARREN 0 . S80/GREASE WARREN D. $580 / 18$ E. HGHLN C. SBO/IB SLOUGH 6-2 EAST MESA DUMMY FILLER

PAGE 
Table 4. IVEP keyword file.

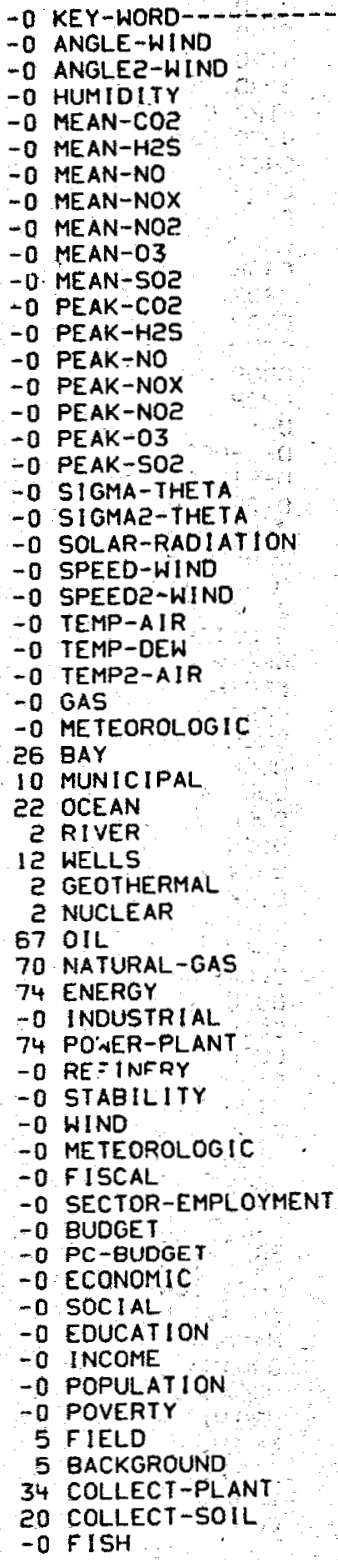

FUELI

FUELI

FUEL 1

FUEL2

SAMP. TYPE,

TYPE PLANT

TYPE PLANT

TYPE PLANT

SAMPLINO

ACTION

ACTION

ANIMAL

ANIMAL 
Table 4. (Continued)

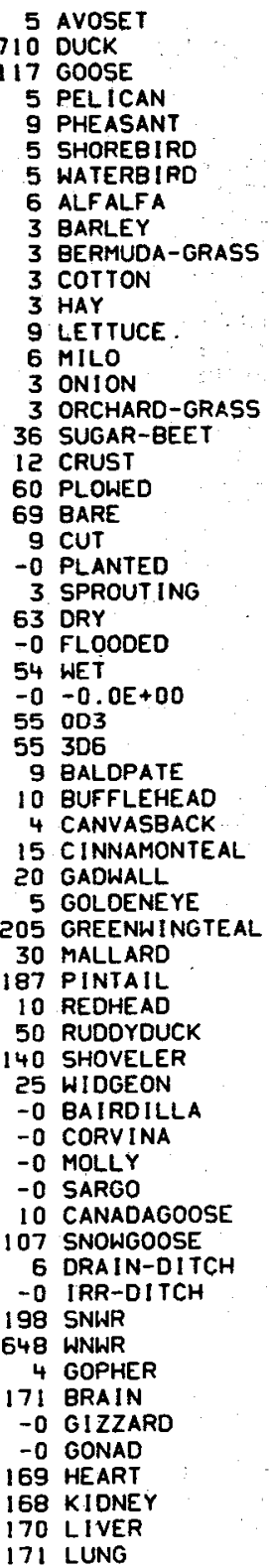

OIRD
BIRD
BIRD
BIRD
GIRD
GIRD CLASS
BIRD CLASS
CROP
CROP
CROP
CROP
CROP
CROP
CROP
CROP
CROP
CROP
D-
D-CROP
D-FIELD
D-GROWTH
D-GROWTH
D-GROWTH
D-WATER
D-WATER
D-WATER
OEPTH
DEPTH
DEPTH
DUCK
DUCK
DUCK
DUCK
DUCK
DUCK
DUCK
DUCK
DUCK
DUCK
DUCK
DUCK
DUCK
FISH
FISH
FISH
FISH
GOOSE
GOOSE
LOCATION
LOCATION
LOCATION
LOCATION
MAMMAL
ORGAN
ORGAN
ORGAN
ORGAN
ORGAN
ORGAN
ORGAN


Table 4. (Continued)

PAGE

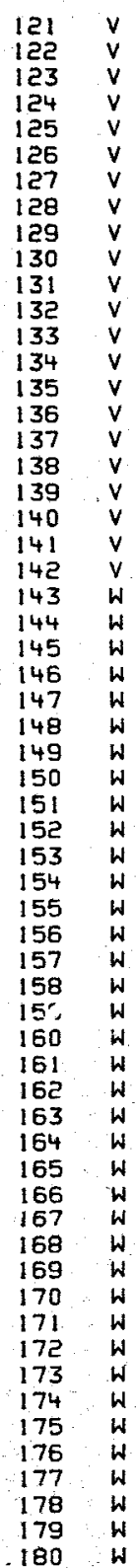

$\begin{aligned} 1 & \text { MUSCLE } \\ -0 & \text { WINGTIP }\end{aligned}$

-O BRINE

8 DUARTERLY

-O SACRIFICE-TIME

- 0 SALINITY

- 0 TOXICITY

- 0 ZINC

5 AQUATIC

846 BIRD

4 MAMMAL

- 0 SEDIMENT

110 SOIL

51 VEGETATION

5 WATER

-O POOL

- 0 TIME.

-0 MALE

- 0 BONE

5 PILEWORM

3 BEECH

1 BEECHSPILL

6 BEST

3 CENTRALMAIN

-0 CENTRALMAIN

2 DAFFODIL

2 DATE

2 DATEZ/DATE3A

2 DOGWOOD

2 DOGWOODLAT2

10 EAST-HIGHLINE

-O EAST-HIGHLINE I4

4 HOLTVILLEMAIN

2 HOLTVILLEZC

2 LIVESLEY

-0 PUMICE

9 PUMICE/VAIL 4 A

2 ROCKWOOD

16 SOGE-SITE

-O SPRUCE

2 SPRUCELATSSPILL

4 SPRUCE 1

4 SPRUCE 3

6 SPRUCE5

39 VAIL 4

11 VAIL 4/VAIL $4 A$

35 VAIL $4 A$

- O VAIL $4 A / P U M I C E$.

-0 VAILYA/VAILL

4 WARREN

-O BRINE.

-D SETTLING

- 0 SPRAY

20 ALAMO

22 NEW

-O OTHER

- 0 SEDIMENT

328 WATER

ORGAN

ORGAN

PARAMETER

PARAMETER

FARAMETER

PARAMETER

PARAMETER

PARAMETER

SAMP. TYPE

SAMP. TYPE

SAMP. TYPE

SAMP: TYPE

SAMP. TYPE

SAMP. TYPE

SAMP. TYPE

SAMP. TYPE

SAMPLE

SERIAL

SEX

TISSUE

WORM

LOCATION

LOCATION

LOCATION

LOCATION

LOCATION

LOCATION

LOCATION

LOCATION

LOCATION

LOCATION

LOCATION

LOCATION

LOCATION

LOCATION

LOCATION

LOCATION

LOCATION

LOCATION

LOCATION

LOCATION

LOCATION

LOCATION

LOCATION

LOCATION

LOCATION

LOCATION

LOCATION

LOCATION

LOCATION

LOCATION

POND

POND

POND

RIVER

RIVER

SAMP. TYPE

SAMP. TYPE

SAMP. TYPE 
Table 4. (Continued)

PAGE

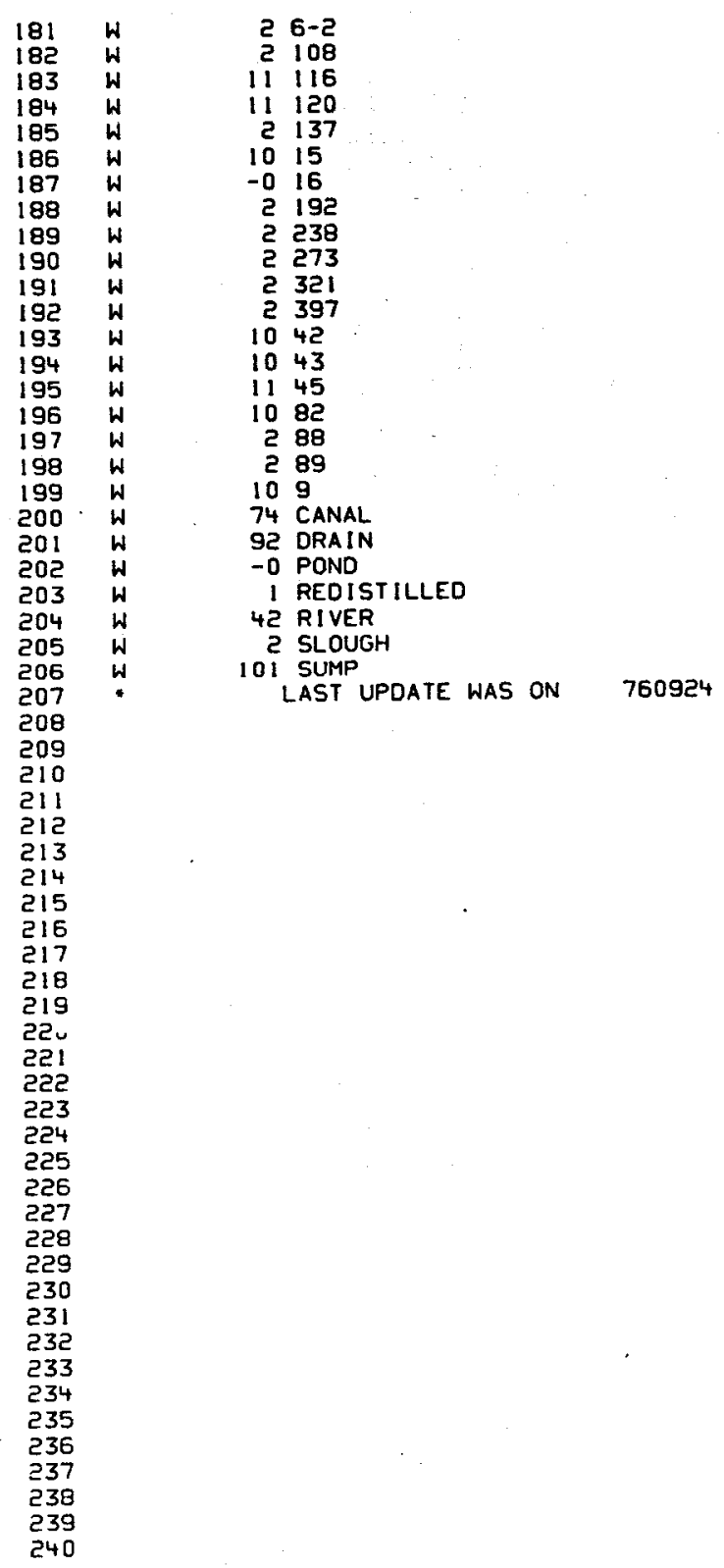


Table 5. IVEP parameter file.

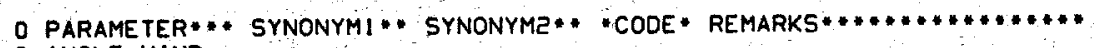

- 0 ANGLE-WIND

-O ANGLEZ-WIND

-O HUMIDITY

- 0 MEAN-COZ

- D MEAN-H2S

-O MEAN-NO

-D MEAN-NOX

- D MEAN-NOZ

-0 MEAN-03

- 0 MEAN-SO2

- 0 PEAK-COZ

-O PEAK-HES

-O PEAK-NO

-D PEAK-NOX

- D PEAK-NOZ

-0 PEAK-03
-0 PEAK- 502

- 0 SIGMA-THETA

- O SIGMA2-THET

- O SOLAR-RAD

-O SPEED-WIND

-O SPEEDZ-WIND

-0 TEMP-AIR

-0. TEMPZ-AIR

72 COOL.ING-TYPE

72 HEAT-RATING

72 PART ICULATES

72 AOC-REGION

72 AVG-H2O-CONS

72 HZO-SOURCE

72 OWNER

COMPANY

- 0 DOC

72 GENERATION

72 TYPE

72 NGC

72 PLT-CAPACITY CAPACITY

72 NAME

72 ROC

75 S-CONTENT

72502

72 NOX

72 UPC

1 FORMAT

1 FILENAME

59 ED-A:00-07YR

59 ED-A:08 YR

59 ED-A:09-11YR

$59 \mathrm{ED}-\mathrm{A}: 12$ YR

59 ED-A:13-15YR

59 ED-A:16+ YR

58 COPCS-CON/RE

59 POP:CO TOTAL

$58 \mathrm{CO}$ \$-P-PROT

58 COPCS-P-PROT

$58 \mathrm{CO}$ \$-DEBTSE

58 COPCS-DEBTSE

58 CO \$-EDUC

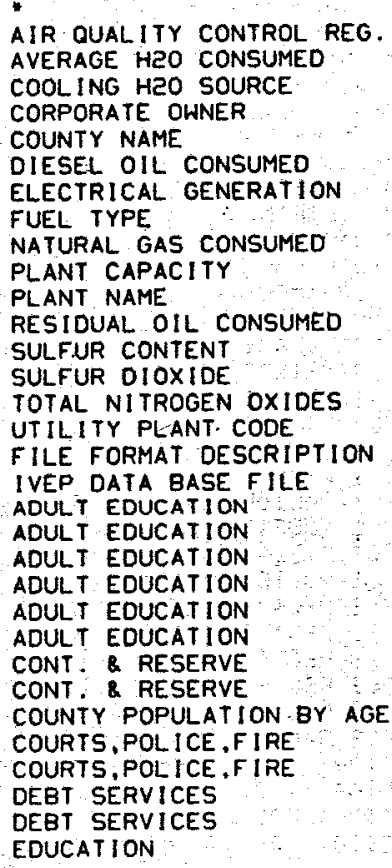


Table 5. (Continued)

PAGE

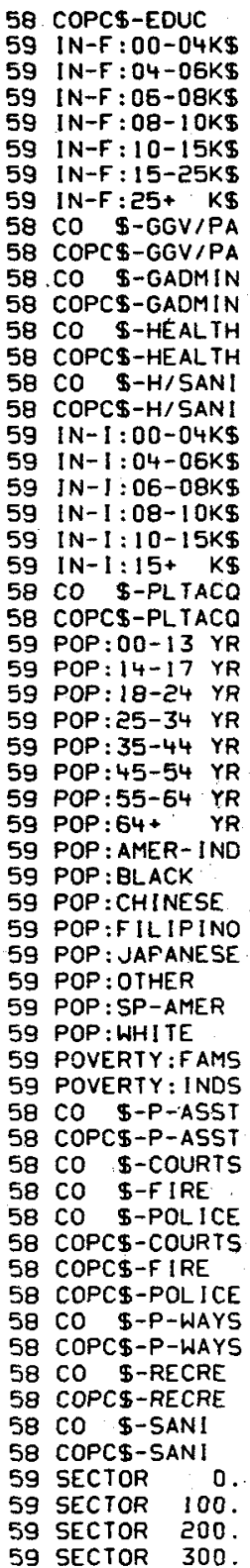

EDUCATION

FAMILY INCOME

FAMILY INCOME

FAMILY INCOME

FAMILY INCOME

FAMILY INCOME

FAMILY INCOME

FAMILY INCOME

GEN. GOV. PLANT ACQ.

GEN GOV PLANT ACO.

GENERAL ADMINISTRATION

GENERAL ADMINISTRATION

HEALTH

HEAL TH

HEALTH, SANI TATION

HEALTH, SANITATION

INDIVIDUAL INCOME

INDIVIDUAL INCOME

INDIVIDUAL INCOME

INDIVIDUAL INCOME

INDIVIDUAL INCOME

INDIVIDUAL INCOME

PLANT ACOUISITION

PLANT ACQUISITION

POPULATION BY AGE

POPULATION BY AGE

POPULATION BY AGE

POPULATION BY AGE

POPULATION GY AGE

POPULATION BY AGE

POPULATION BY AGE

POPULATION BY AGE

POPULATION BY RACE

POPULATION BY RACE

POPULATION BY RACE

POPULATION BY RACE

POPULATION BY RACE

POPULATION BY RACE

POPULATION BY RACE

POPULATION BY RACE

POVERTY FAMILIES

POVERTY INDIVIDUALS

PUBLIC ASSISTANCE

PUBLIC ASSISTANCE

PUELIC PROTECTION

PUBLIC PROTECTION

PUBLIC PROTECTION

PUBLIC PROTECTION

PUBL IC PROTECTION

PUBLIC PROTECTION

PUBLIC WAYS \& FACILITIES

PUBL IC WAYS \& FACILITIES

RECREATION

RECREATION

SANITATION

SANITATION

SECTOR EMPLOYMENT

SECTOR EMPLOYMENT

SECTOR EMPLOYMENT

SECTOR EMPLOYMENT 
Table 5. (Continued)

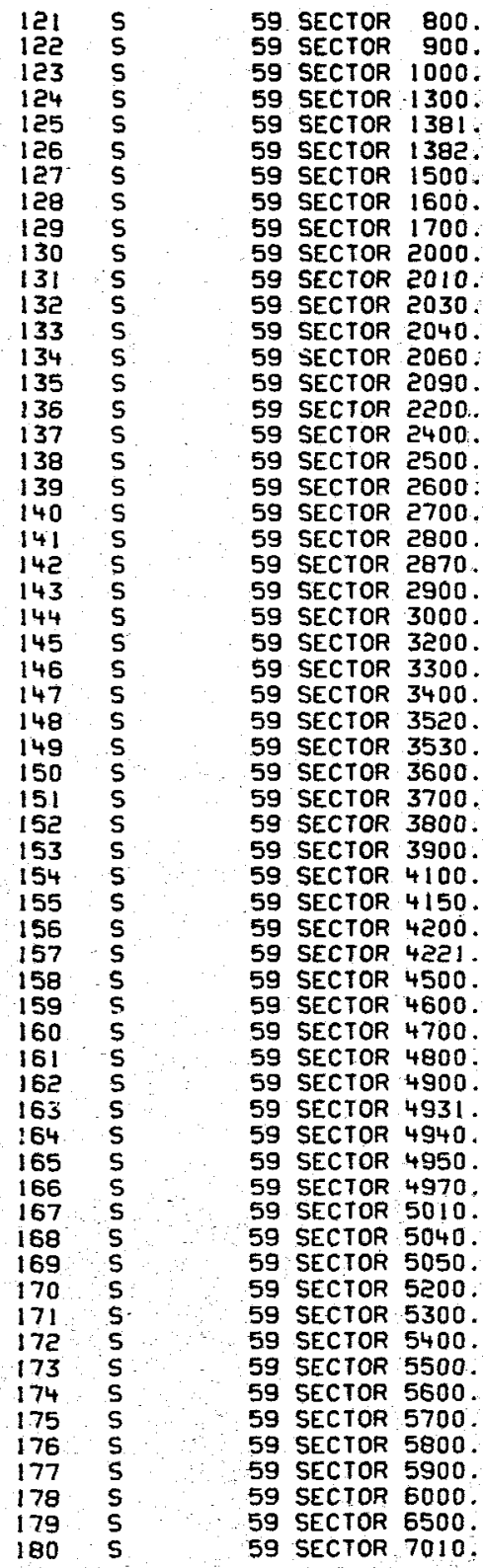

SECTOR EMPLOYMENT SECTOR EMPLOYMENT SECTOR EMPLOYMENT SECTOR EMPLOYMENT SECTOR EMPLOYMENT SECTOR EMPLOYMENT SECTOR EMPLOYMENT SECTOR EMPLOYMENT SECTOR EMPLOYMENT SECTOR EMPLOYMENT SECTOR EMPLOYMENT SECTOR. EMPLOYMENT SECTOR EMPLOYMENT SECTOR EMPLOYMENT SECTOR EMPLOYMENT SECTOR EMPLOYMENT SECTOR EMPLOYMENT SECTOR EMPLOYMENT SECTOR EMPLOYMENT SECTOR EMPLOYMENT SECTOR EMPLOYMENT SECTOR EMPLOYMENT SECTOR EMPLOYMENT SECTOR EMPLOYMENT SECTOR EMPLOYMENT SECTOR EMPLOYMENT SECTOR EMPLOYMENT SECTOR EMPLOYMENT SECTOR EMPLOYMENT SECTOR EMPLOYMENT SECTOR EMPLOYMENT SECTOR EMPLOYMENT SECTOR EMPLOYMENT SECTOR EMPLOYMENT SECTOR EMPLOYMENT SECTOR EMPLOYMENT SECTOR EMPLOYMENT SECTOR EMPLOYMENT SECTOR EMPLOYMENT SECTOR EMPLOYMENT SECTOR EMPLOYMENT SECTOR EMPLOYMENT SECTOR ENPL OYMENT SECTOR EMPLOYMENT SECTOR EMPLOYMENT SECIOR EMPLOYMENT SECTOR EMPLOYMENT SECTOR EMPLOYMENT SECTOR EMPLOYMENT SECTOR EMPLOYMENT SECTOR EMPLOYMENT SECTOR EMPLOYMENT SECTOR EMPLOYMENT SECTOR EMPLOYMENT SECTOR EMPLOYMENT SECTOR EMPLOYMENT SECTOR EMPLOYMENT SECTOR EMPLOYMENT SECTOR EMPLOYMENT SECTOR EMPLOYMENT 
Table 5. (Continued)

PAGE

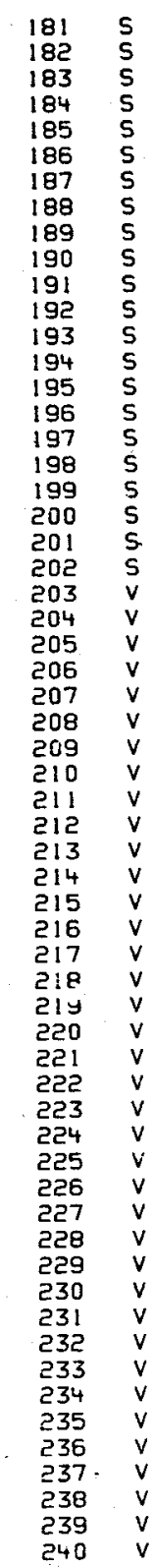

59 SECTOR 7030.

59 SECTOR 7200 :

59 SECTOR 7512

59 SECTOR 7800.

59 SECTOR 7900

59 SECTOR 7940.

59 SECTOR 8000

59 SECTOR 8060.

59 SECTOR 8200.

59 SECTOR 8600.

59 SECTOR 10000.

59 SECTORIO700.

59 SECTOR 15000.

59 SECTOR 19000.

59 SECTOR40000.

59 SECTOR50000.

59 SECTOR52000.

59 SECTOR60000.

59 SECTORTODOO.

58 CO \$-TOTAL

58 COPCS-TOTAL

- 0 COUNT

$5 \mathrm{PH}$

- O STD-LENGTH LENGTH

5 TEMPERATURE TEMP

- 0 WE-IGHT

- 0 ACTINIUM

45 ALUMINUM

-O AMERICIUM

49 ANTIMONY

-O ARGON

65 ARSENIC

- 0 ASTATINE

45 BARIUM

-0 BERKELIUM

- 0 BERYLLIUM

- 0 BISMUTH

- 0 BORON

224 BROMINE

10 CADMIUM

61 CALCIUM

-O CALIFORNIUM

-D CARBON

46 CERIUM

48 CESIUM

46 CHLORINE

48 CHROMIUM

52 COBALT

187 COPPER

-0 CURIUM

39 DYSPROSIUM

-0 EINSTEINIUM

-0 ERBIUM

46 EUROPIUM

-O FERMIUM

-O FLUORINE

- O FRANCIUM

- 0 GADOL INIUM
COND

AC 89

89

13
95

51
18
33

33

85
56

97

43

5

35
48

20

20

68

55

17

24
27

27
29

96

56

99
68

63

100

9
87

64
SECTOR EMPLOYMENT SECTOR EMPLOYMENT SECTOR EMPLOYMENT SECTOR EMPLOYMENT: SECTOR EMPLOYMENT SECTOR EMPLOYMENT SECTOR EMPLOYMENT SECTOR EMPLOYMENT SECTOR EMPLOYMENT. SECTOR EMPLOYMENT SECTOR EMPLOYMENT SECTOR EMPLOYMENT SECTOR EMPLOYMENT SECTOR EMPLOYMENT SECTOR EMPLOYMENT SECTOR EMPLOYMENT SECTOR EMPLOYMENT SECTOR EMPLOYMENT SECTOR EMPLOYMENT SECTOR EMPLOYMENT TOTAL BUDGET TOTAL BUDGET
ELEMENT
ELEMENT
ELEMENT
ELEMENT
ELEMENT
ELEMENT
ELEMENT
ELEMENT
ELEMENT
ELEMENT
ELEMENT
ELEMENT
ELEMENT
ELEMENT
ELEMENT
ELEMENT
ELEMENT
ELEMENT
ELEMENT
ELEMENT
ELEMENT
ELEMENT
ELEMENT
ELEMENT
ELEMENT
ELEMENT
ELEMENT
ELEMENT
ELEMENT
ELEMENT
ELEMENT
ELEMENT 
Table 5. (Continued)

PAGE

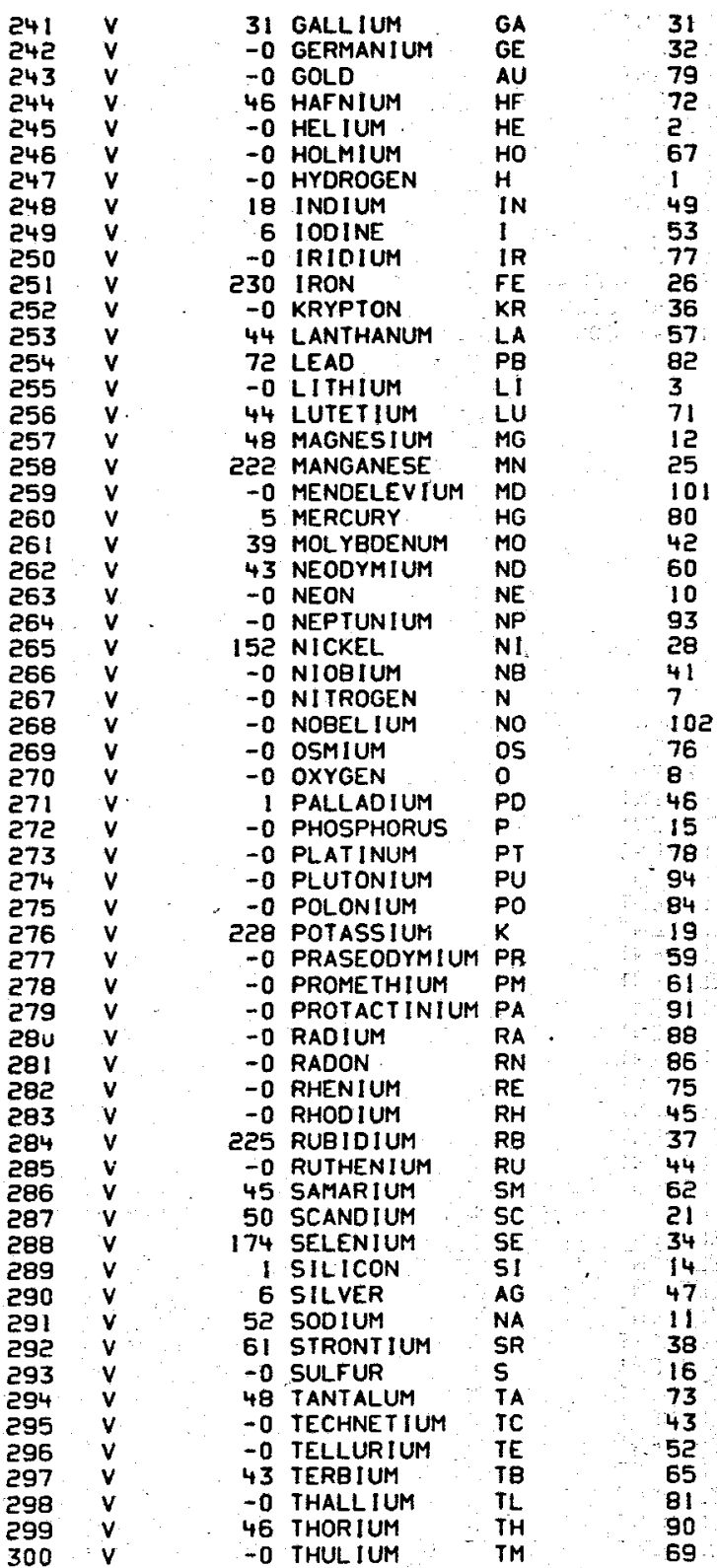

ELEMENT

ELEMEN

ELEMENT

ELEMENT

ELEMENT

ELEMENT

ELEMENT

ELEMENT

ELEMENT

ELEMENT

ELEMENT

ELEMENT

ELEMENT

ELEMENT

ELEMENT

ELEMENT

ELEMENT

ELEMENT

ELEMENT

ELEMENT

ELEMENT

ELEMENT

ELEMENT

ELEMENT

ELEMENT

ELEMENT

ELEMENT

ELEMENT

ELEMENT

ELEMENT

ELEMENT

ELEMENT

ELEMENT

ELEMENT

ELEMENT

ELEMENT

ELEMENT

ELEMENT

ELEMENT

ELEMENT

ELEMENT

ELEMENT

ELEMENT

ELEMENT

ELEMENT

ELEMENT

ELEMENT

ELEMENT

ELEMENT

ELEMENT

ELEMENT

ELEMENT

ELEMENT

ELEMENT

ELEMENT

ELEMENT

ELEMENT

ELEMENT 
Table 5. (Continued)

PAGE

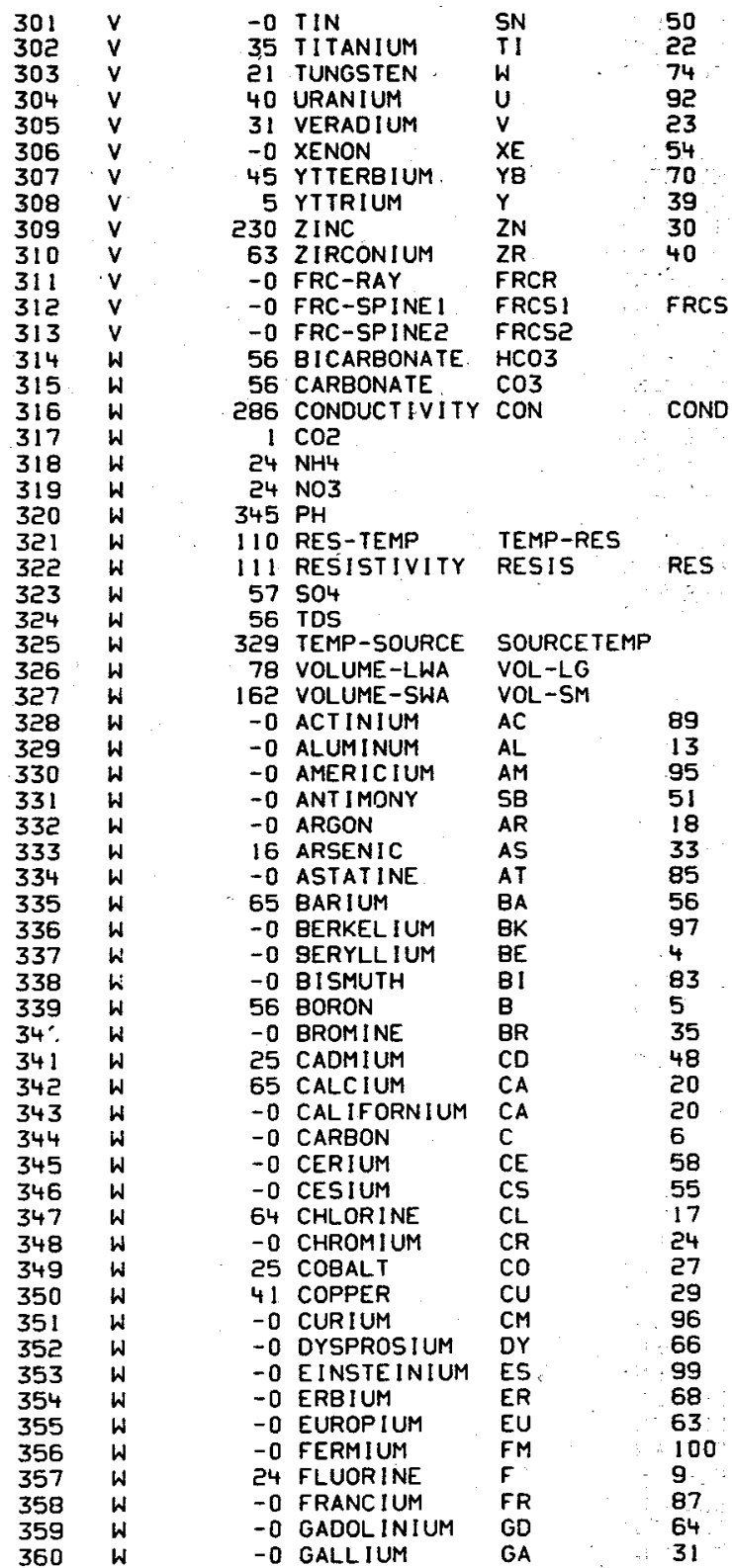

ELEMENT

ELEMENT

ELEMENT

ELEMENT

ELEMENT

ELEMENT

ELEMENT

ELEMEN

ELEMENT

ELEMENT

FINRAY COUNTS

FINRAY COUNTS

FINRAY COUNTS

COND

.

ELEMENT

ELEMENT

ELEMENT

ELEMENT

ELEMENT

ELEMENT

ELEMENT

ELEMENT

ELEMENT

ELEMENT

ELEMENT

ELEMENT

ELEMENT

ELEMENT

ELEMENT

ELEMENT

ELEMENT

ELEMENT

ELEMENT

ELEMENT

ELEMENT

ELEMENT

ELEMENT

ELEMENT

ELEMENT

ELEMENT

ELEMENT

ELEMENT

ELEMENT

ELEMENT

ELEMENT

ELEMENT 
Table 5. (Continued)

PAGE

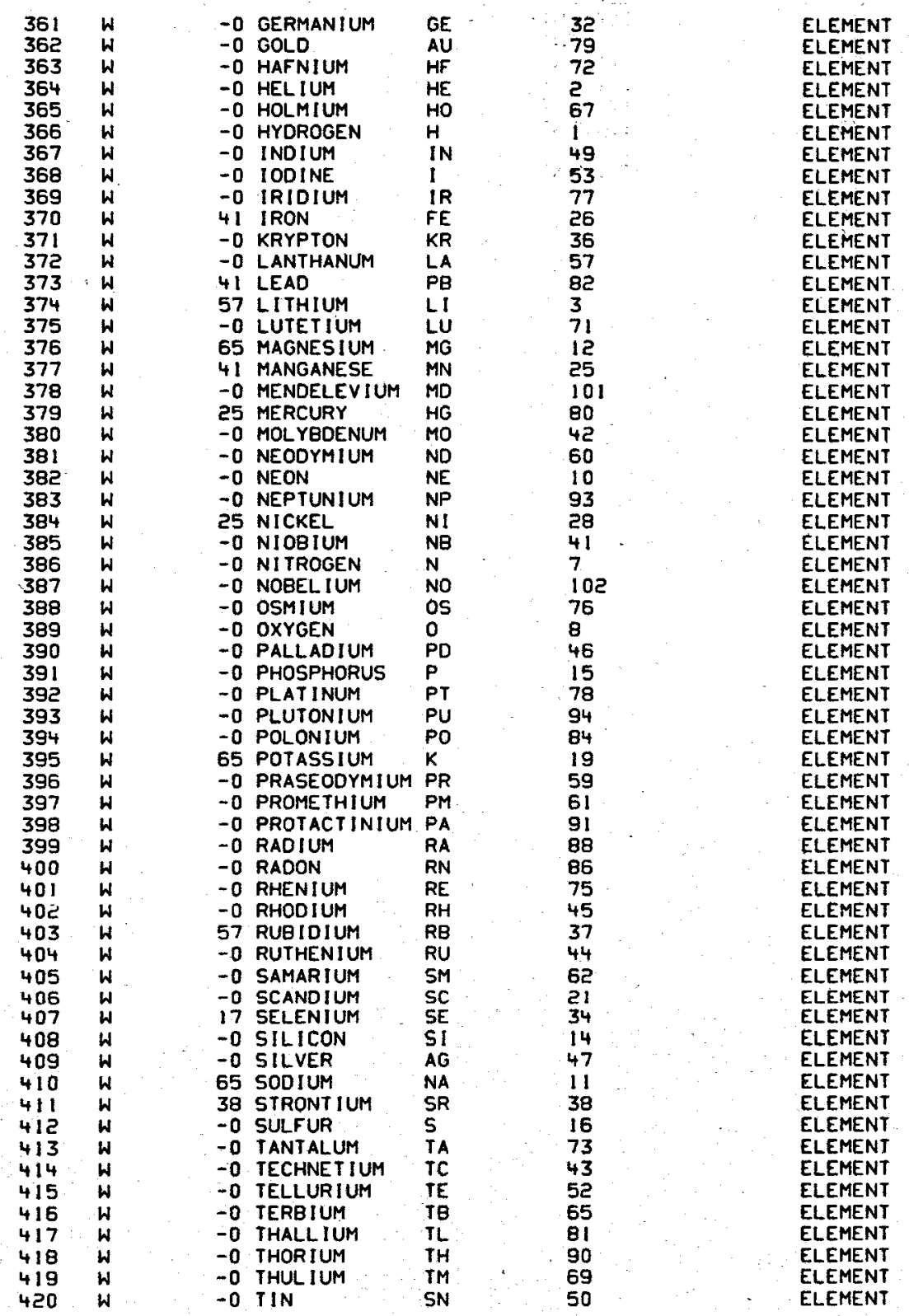


Table 5. (Continued)

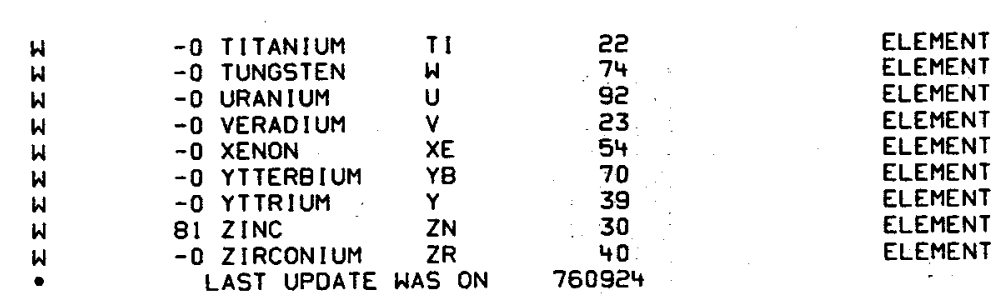


Table 6. IVEP experimental method-code file.

T MTD 01 METHOD CODE IN COLUMNS 5-7, CARD SEQUENCE NUMBER IN COLUMNS 9 AND 10

- MTD OZ COLUMNS 12 THRU 80 USED TO DEFINE METHOD, LIMIT IS 99 SEOUENCED CARDS

- AAS 01 ATOMIC ABSORPTION

- ASP 0I ANODIC STRIPPING POLAROGRAPHY

- col ol colorimetry

- CSP OI CATHODIC STRIPPING POLAROGRAPHY

- EMS OI EMISSION SPECTROSCOPY

- Fes di flame emission

- gra ol gravimetric

- ise ol lon-specific electrode

- NaA oI neutron activation

- RTC ol REAL TIME Clock

- tit ol iItration

- XRF ol X-RAY fuORSENSE

A CIL OI CHEMILUMINESCENCE

A CUP OI CUP ANEONMETER

A EHG OI ELECTROSTATIC-HG

A IRA OI IR ABSORBTION

A LAT 01 LEAD ACETATE TAPE

A PFL OI PULSE FLOO

A RAD DI RADIOMETER

A SGM DI SIGMA METER

A TBP 01 THEMISTOR

A TFC OI THIN-FILM CAPICATOR

A UVA OI UV ABSORBTION

A VNE OI VANE

Y CBP OI CONDUCTIVITY BY PROBE

$\checkmark$ ELP 01 ELAPSED

$\checkmark$ KNT OI BY COINT

$\checkmark$ PHM DI PH BY METER

$\checkmark$ RUL OI MEASUREMENT BY RULER

$\checkmark$ SCL OI: SCALE WEIGHT

$\checkmark$ TBP 01 TEMPERATURE BY PROBE

W AOA OI AOAC 4TH ED. 1970. METHOD 33.010

$W$ CBB OI CONDUCTIVITY VIA BECKMAN SOLUBILITY BRIDGE

W CBP OI CONDUCTIVITY BY PROBE

W PHH OI PH BY HACH

W PHM OI PH BY METER

$W$ PHP OI PH BY LITMIS PAPER

W RBM OI RESISTIVITY BY METER

W. TBP OI TEMPERATURE BY PROBE

W TBT OI TEMPERATURE BY THERMOMETER

$W$ VBF 01 VOLUME BY FLASK

W 102 OI APHA AND AWWA METHOD $102,13 T H$ ED. STANDARD METHODS

$W$ I 21 OI APHA AND AWWA METHOD $1210,13 T H$ ED. STANDARD METHODS

$W 148$ OI APHA AND AWWA METHOD $148 C, 13$ TH ED. STANDARD METHOOS

W 156 OI APHA AND AWWA METHOO 156C, I ITH ED. STANDARD METHODS 
Table 7. IVEP Laboratory-of-Analysis-code file.

PAGE

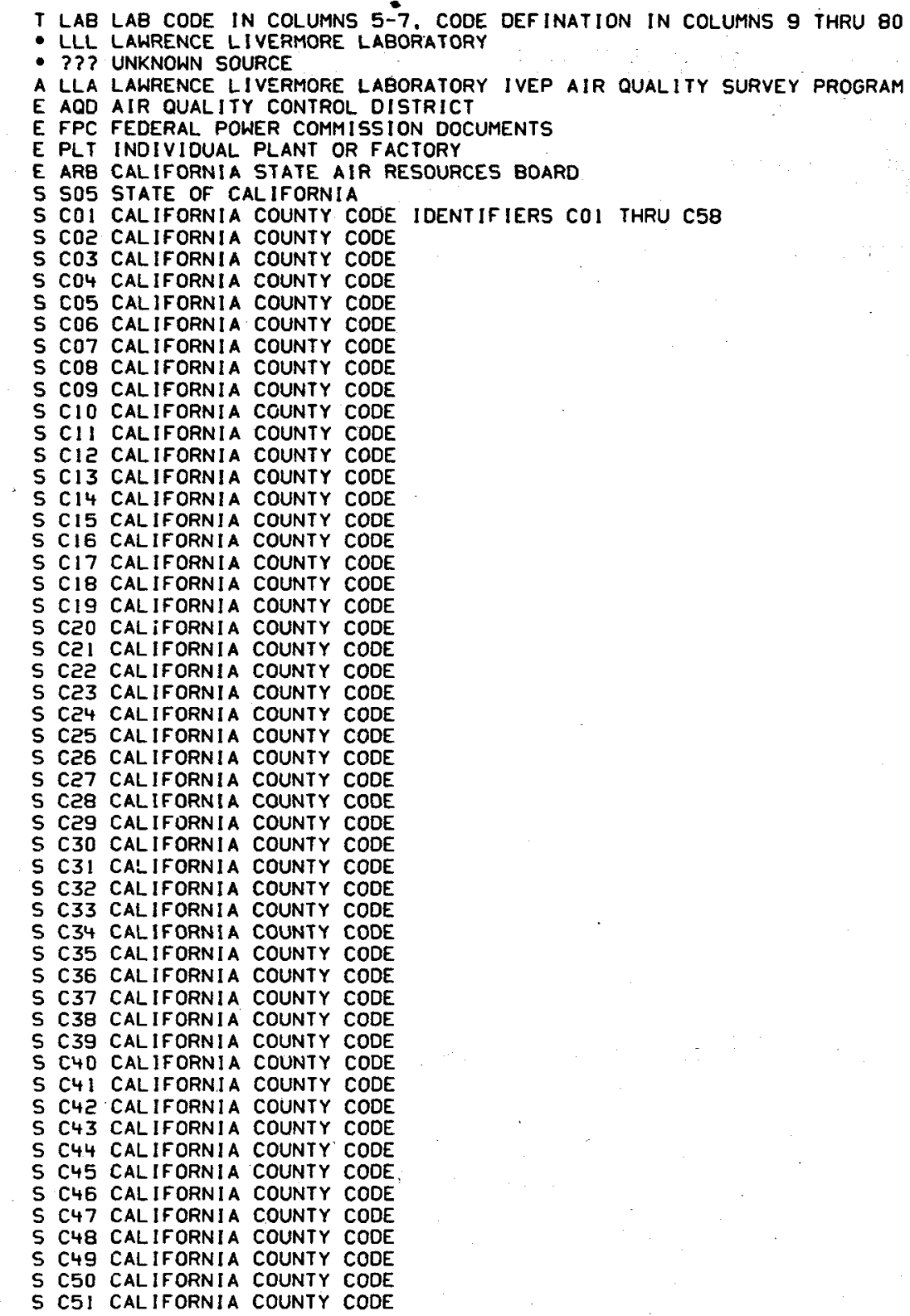


Table 7. (Continued)

PAGE

S C52 CALIFORNIA COUNTY CODE

5 C53 CALIFORNIA COUNTY CODE

5 C54 CALIFORNIA COUNTY COOE

S C55 CALIFORNIA COUNTY CODE

5 C56 CAL IFORNIA COUNTY CODE

5 C57 CALIFORNIA COUNTY CODE

S C5B CALIFORNIA COUNTY CODE

S CEN U.S. BUREAU OF. THE CENSUS

$S$ CBP U.S. DEPT OF COMMERCE, COUNTY BUSINESS PATTERNS

$\checkmark$ LLV LAWRENCE LIVERMORE LABORATORY IVEP ECO-SYSTEM FIELD SURVEY PROCRAM

H GHT GHT LABORATORIES OF IMPERIAL VALLEY, INC.

W VET HOWARO AGRI CUL TURE CONSUL TAT ION AND RESEARCH, BRAWLEY, CA.

W LCH LAWRENCE LIVERMORE LABORATORY CHEMISTRY GROUP

W LLW LAWRENCE LIVERMORE LABORATORY IVEP WATER QUALITY FIELD SURVEY PROGRAM 
Table 8. IVEP unit-code file.

PAGE

T UNT UNIT CODE IN COLUMNS 5-7, CODE DEFINATION IN COLUMNS 9 THRU 80

- ol5 micrograms per cubic meter

- ool micrograms PER GRAM

- ooz micrograms per gram ash

- O03 MICROGRAMS PER GRAM DRY

- 004 MICROGRAMS PER GRAM WET

- 005 MICROGRAMS PER KILOGRAM

- 006 Micrograms PER kilogram oRy

- 007 MICROGRAMS PER KILOGRAM=WET

- oog micRograms PER liter

- D08 MICROGRamS PER MILligram

- olo Micrograms PER MILlil ITER

- ol 4 micrograms PER sample

- olz micrograms PER SCF

- Dil micrograms Per souare centimeter

- 013 MICROGRAMS PER STAGE

A DEG DEGREES THETA

A STD LOCAL TIME REPORTED AS YYMMODHHMM

A MPS METERS PER SECONO

A PPB PARTS PER BILLION

A PPM PARTS PER MILLION

E AFY ACRE-FEET PER YEAR

$E$ BPY BARRELS PER YEAR

E BTU BTU

E BKH BTU PER KILOWATT-HOUR

E KBY KILOBARRELS PER YEAR

E KTY KILOTONS PER YEAR

E MHR MEGAWATT-HOURS

E MHY MEGAWATT-HOURS PER YEAR

E MWT MEGAWATTS

E MWE MEGAWATTS ELECTRIC

E MCF MILLION CUBIC FEET

E PER PERCENT

E TPY TONS PER YEAR

5 \$\$\$ DOLLARS

5 FAM FAMILIES

$S$ POP PEOPLE

$\checkmark$ ABS ABSOLUTE COUNT

$\checkmark$ CTM CENTIMETERS

$\checkmark$ KNT COUNT

$\checkmark$ GMS GRAMS

$\checkmark$ HRS HOURS

$\checkmark$ KGM KILOGRAM

$\checkmark$ MTS METERS

$\checkmark$ MGM MILLIGRAMS

$W$ DGC DEGREES CENT IGRADE

$W$ DGF DEGREES FAHRENHE IT

$W$ DGK DEGREES KELVIN

$W$ GPL GRAMS PER LITER

$W$ LIT LITERS

W UPL MICROGRAMS PER LITER

W UMC MICROMHOS / CENTIMETER

W MPL MILLIGRAMS PER LITER

W MMC MILLIMHOS/CENTIMETER

$W$ NUN NO ASSOCIATED UNIT

W OMM OHM-METERS 
"M" reports the error. Finally, a "U". Indicates that the code files have been updated for the information given on that data line. A brief summary is provided at the end of each output file. Corrections may be made as necessary via teletypewriter or punched cards.

Tables 9 through 12 are examples of card-image-data files. Table sequence 9 portrays the processing procedure of an error-dubbed-input f1le (Table 9a). Table $9 b$ is the first output file; Table $9 c$ is the output of the corrected version of Table 9b. Finally Table $9 \mathrm{~d}$ is the final output file as it appears in the IVEP Data Base. Note that the final file reflects updating of the code files discussed above.

Table 10 again demonstrates the processing procedure. Note that the geographic Information, i.e. latitude and longitude, has been generated from the fixed-site code embedded within the identifier. Also, use was made of the parameter-synonym file (Table 5).

Tables 11 and 12 are typical data files; the first is an example of Input from the Socioeconomic Program Table 12 presents sol1-sample data taken by the Ecosystems Program at depths of zero to three Inches ( $\emptyset \mathrm{D} 3$ ) and three to six (3D6) inches. No analytical results have yet

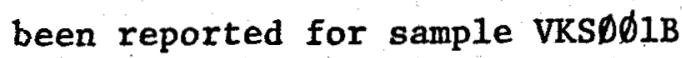

as shown by the missing $4 \emptyset \emptyset$-type cards.

The Air Quality Program and miscellaneous data bases do not fit the IVEP Data-Base Plan conveniently. The Air Quality group generates an enormous number of data points; most miscellansous non-LLL data bases are not directly compatible with the IVEP Data Base format. For these reasons each will be reported separately and indexed in such a manner to conform with the IVEP Data-Base P1an.

Air Quality data are transferred to the IVEP Data-Base via computerdisk files. Each file consists of multiple records reported by time for individual fixed-site gas/ meteorologic sampling stations. Files are named as follows: $A * *$ YMDDmdd where $A=$ LLL Air Quality Program identifier, $* *$ = the fixed-site-station identifier, $Y=$ the last digit of the year of the first data record, $M=$ the month of the first data record (1 through 9 , $\mathrm{J}, \mathrm{K}, \mathrm{L}$ ),

$D D=$ the day of the first data record (zero filled),

$m=$ the month of the last data record ( 1 thru $9, \mathrm{~J}, \mathrm{~K}, \mathrm{~L})$, and

dd = the day of the last data record (zero filled). 
Table 9a. Data-input file 1 (State electrical energy data).

PAGE

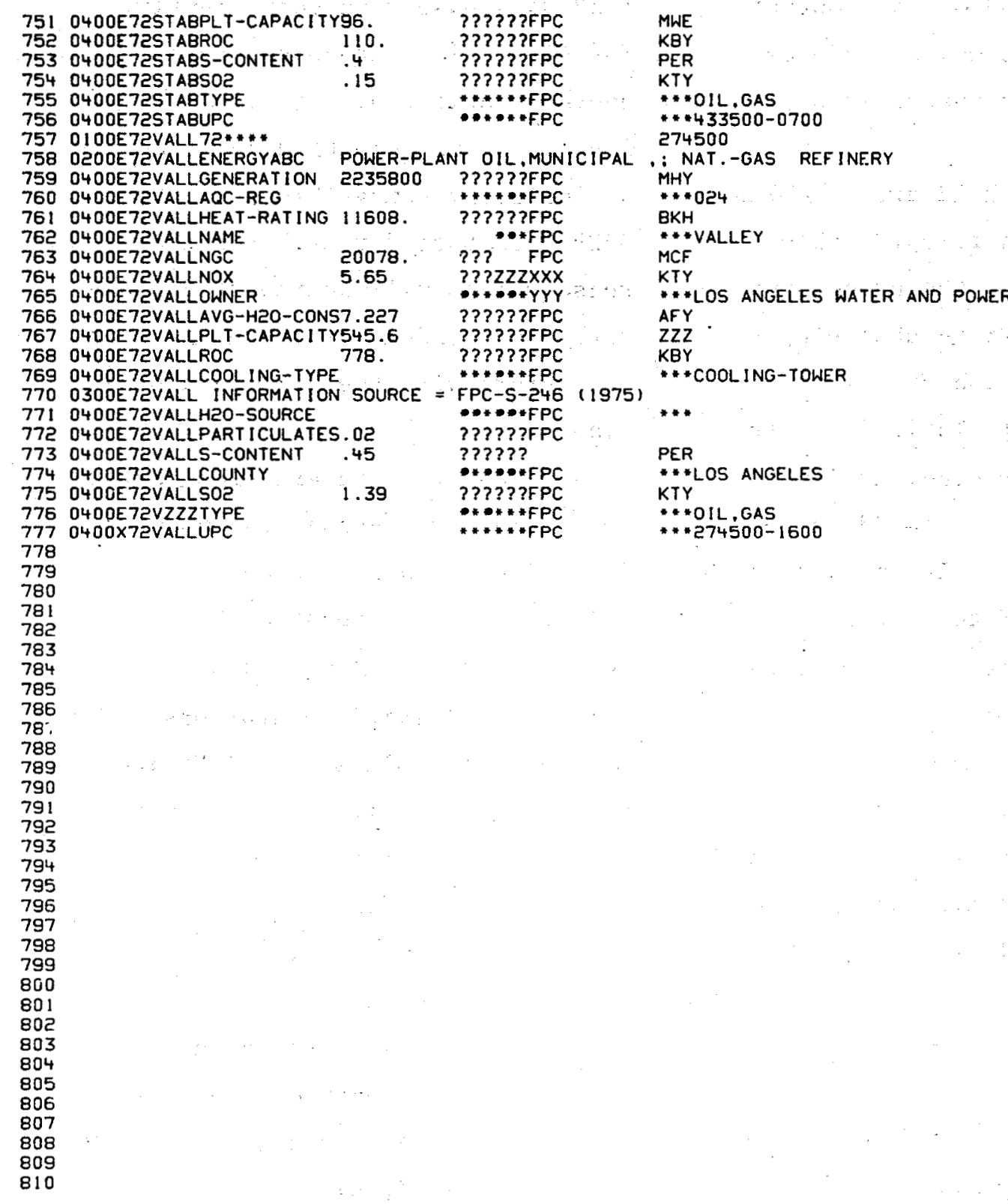

Note: There are 20 demonstration errors purposely entered here for sample E72VALL. The preprocessor will identify these errors (see Table 9b). 
Table 9b. Output file 1.1 (Output of input-data set Table 9a.)

PAGE

751 C400E 72STABPLT-CAPACITY96.

C4DDE72STABROC

753 C400E72STABS-CONTENT IIO.

754 C400E72STABSOZ

755 C4DOE $22 S T A B T Y P E$

756 C4ODE72STABUPC

757 MIOOET2VALL

758 MIOOE72VALL

759 EIOOE72VALL72***

760 M2OOET2VALL

761 MaOOETZVALL

762 MEOOET2VALL 'NAT.-GAS:

763 M200ET2VALL REF INERY:

764 E200E72VALLENERGYABC POWER-PLANT OIL,MUNICIPAL ;: NAT. -GAS REFINERY

765 C300E72VALL INFORMATION SOURCE = FPC-5-246 11975

766 M400E72VALLAOC-REG

767 E400E72VALLAQC-REG

768 C400E72VALLAVG-H2O-CONS7.227

769 C400E72VALLCOOLING-TYPE

770 C4DOET2VALLCOUNTY

771 M400E72VALLGENERATION

772 E400E 2 VALLGENERATION

773 M4O0E72VALLH2O-SOURCE

774 E4 OOE 72VALLHEO-SOURCE

775 C400E72VALLHEAT-RATING 11608.

776 M400E72VALLNAME

777 E400E 72 VALLNAME

778 M4O0E 72 VÁLLNGC

779 E400E72VALLNGC

780 M400E72VALLNOX

781 M4OOE72VALLNOX

782 E400E72VALLNOX

783 M4OOE 72 VALLOWNER

784 E400E 72VALLOWNER

785 M400E72VALLPARTICULATES

786 E400E72VALLPART ICULATES.02

79, M400E72VALLPLT-CAPACITY

-88 E400E72VALLPLT-CAPACITY545.6

789 C400E72VALLROC

790 M4O0E72VALLS-CONTENT

791 E4ODE T2VALLS-CONTENT

792 C4DOET2VALLSO2

793 M4OOE72VZZZ

794 C4OOE 2 VZZZZTYPE

795 M400X72VALL

796 M400X72VALL

$798 \mathrm{M}: 2760926$

$799 M \quad 2760926$

800 M Z760926

$801 \mathrm{M} 2760926$

802 M. 2760926

803

804.

805
806

807

809
37??73FPCNP760926MWE

??????FPCNP760926KBY

?3???3FPCNP760926PER

??????FPCNP760926KTY

?..... *FPCNP760926**0IL,GAS

* ** *FPCNP760926* * *33500-0700

274500

2235800 ??????FPC $\mathrm{MHY}$

n.....FPC , n...

??????FPCNP7609268KH

\#FPC \#VALLEY

20078. ??? FPC MCF

5.65 $\quad 37 ? Z Z Z X X X \quad K T Y$

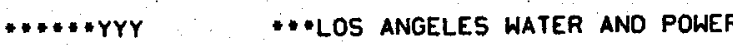

??????FPC

3ร7???FPC $2 z 2$

778

??????FPCNP760926KBY

$i .35$

??????

PER

2?????FPCNP760926KTY

\#*FPCNP760926**OLL,GAS

\#**FPCNP760926**274500-1600

TOTAL NUMBER CARDS READ= NUMBER DATA ENTRIES ATTEMPTED=

NUMBER CARDS ASSIGNED=

TOTAL NUMBER LINES WRITTEN= NUMBER ERRORS WRITTEN=
777

797

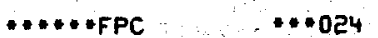

ERROR-- SITE CODE UNDEF INED ERROR-- NO LOCATION KNOWN

ERROR-- UNDEF INED SAMPLE TYPE ERROR-- SAMPLE TYPE NOT A KEY - UNDEF INED KEY. ERROR

ILLEGAL KEYWORD PAIR ERROR

ERROR-- UNDEF INED PARAMETER

ERROR-- BAD VALUE SPECIFIED

ERROR-- NO VALUE OR REMARK

ERROR-- BAD ERROR FORMAT

ERROR-- NO METHOD CODE

ERROR-- $B A D$ METHOD CODE $=2 Z Z$ ERROR-- BAD LAB CODE $=\quad X X X$

ERROR - $B A D$ LAB CODE $=$ YYY

ERROR--- NO UNIT CODE

ERROR-- BAD UNIT CODE $=Z Z Z$

ERROR-- NO LAB CODE

ERROR-- MISSING 100 TYPE CARD

ERROR-- GAD SAMPLE PROGRAM ID ERROR-- MISSING 100 TYPE CARD 
Table 9c. Output file 1.2 (Output of corrected data set Table 9b.)

PAGE

751 C400E72STABPLT-CAPACITY96.

752 C4DOE72STABROC

110

753 C4DOET2STABS-CONTENT . 4

754 C4DOET2STABSOZ

755 C4DOE T2STABTYPE

756 C4DOE72STABUPC

757 CI QOE 72 VALL $72, \ldots$

758 C2OOE 72 VALLENERG $Y$

759 C3OOE 72VALL INFORMATION

760 C4ODETEVALLAOC-REGION

761 C400E72VALLAVG-H20-CONS7.227

762 C4DOE 72 VALLCOOL ING-TYPE

753 C400E72VALLCOUNTY

764 C4ODE72VALLGENERATION 2235800

765 C4ODE72VALLH2O-SOURCE

766 C400E 72VALLHEAT-RATING 11608.

767 C400E72VALLNAME

768 C4OOE 72 VALLNGC

769 C4ODE T2VALLNOX

770 C4O0E 72 VALLOWNER

20078. .

5.65

.02

772 C400E 72VALLPLT-CAPACITY545.

773 CUDOE T2VALLROC

C4OOE72VALLROC PACITYS45.

774 C4 OOE 72VALLS-CONT
775 C4OOE 72 VALLSOZ

776 C400E72VALLTYPE

777 C4OOE72VALLUPC

778 M 2760926

$779 \mathrm{M} \cdot 2760926$

$780 \mathrm{M} \quad 2760926$

$781 \mathrm{M} \quad \mathrm{Z760926}$

782 M Z Z760926

783

784

785

786

787

788

789

791

795

793

794

7.95

796

797

798

799
800

801

805

$80 \mathrm{~s}$

804

805

806

807

808

809

810
??????FPCNP760925MWE

??????FPCNP760925KBY

??????FPCNP760926PER

??????FPCNP760926KTY

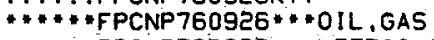

****FPCNP760925**"433500-0700

2745001600

POWER-PLANT : OIL: MUNICIPAL ; NATURAL-GAS

FPC-5-246 (1975)

\#.*.*FPCNP760926**024

??????FPCNP760926AFY

* ***FPCNP760926 * "COOL ING - TOWER

...*.*FPCNP760926***LOS ANGELES

??????FPCNP760926MHY

* ****FPCNP760926** "MUNICIPAL

??????FPCNP7609268KH

* *** *FPCNP760926* *VALLEY "...

??????FPCNP760926MCF

??????FPCNP760926KTY

* * *FPCNP760926** "LOS ANGELES WATER AND POWER

??????FPCNP760926KTY

??????FPCNP760926MWE

??????FPCNP760926KBY

??????FPCNP760926PER

??????FPCNP7609EEKTY

*****FPCNP760926** *0IL, GAS

****FPCNP760926***274500-1600

TOTAL NUMBER CAROS READ=

777

NUMBER DATA ENTRIES ATTEMPTED=
NUMBER CARDS ASSIGNED

NUMBER CARDS ASSIGNED=

NUMBER ERRORS WRITTEN=

777

777 
Table 9d. Output file 1.3 (Final output file - code-file updates indicated.)

PAGE
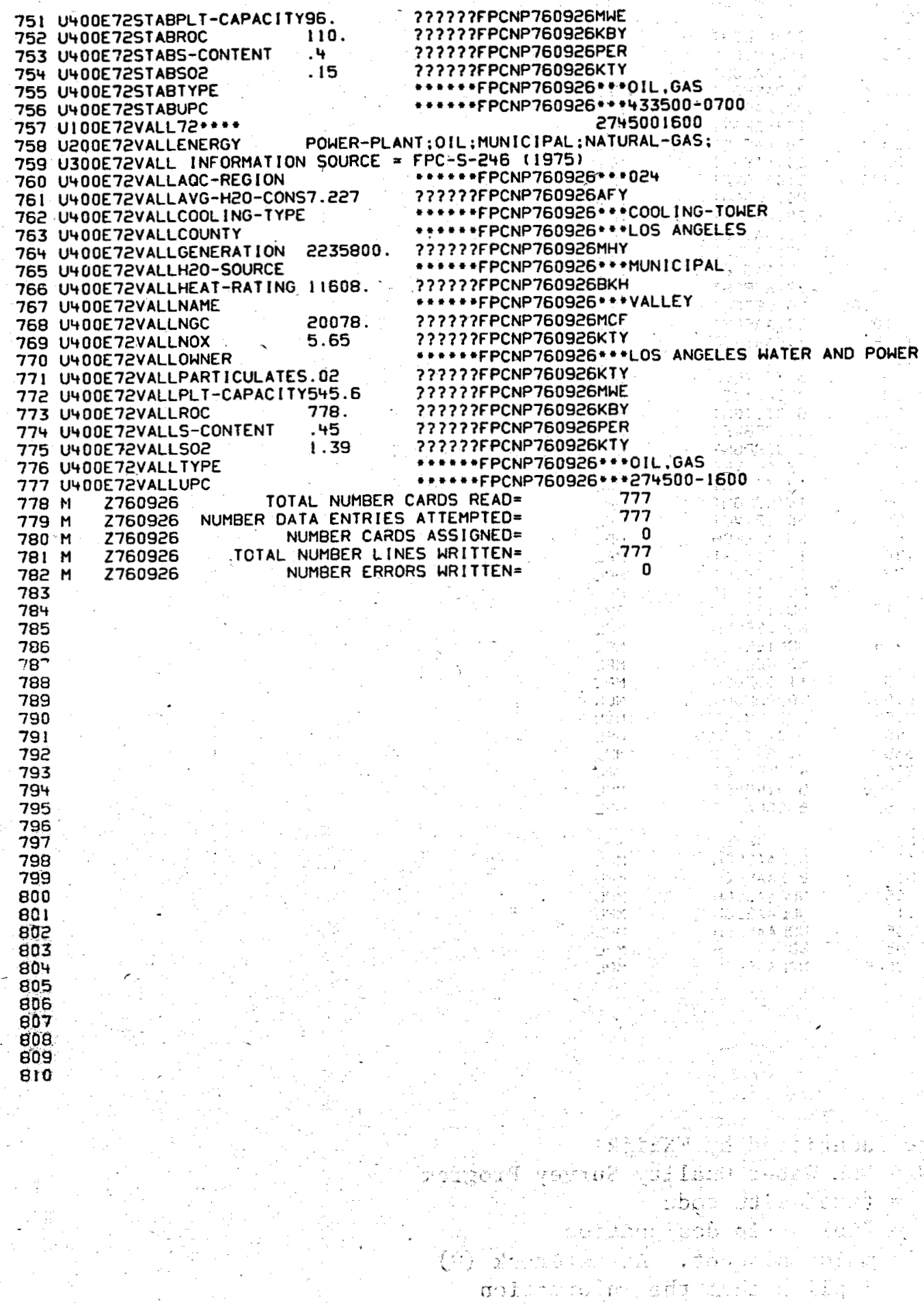
Table 10a. Data-input file 2 (LLL Water Quality Survey. Program.)

PAGE

1 C1OOWABO3* 7602251400
2 C2OOWABO3* WATER

3 C4OOWABO3: COND

4 C4OOWAB03* PH

5 C4OOWABO3* TEMP-SOURCE

6 C40OWABO3 3 VOLUME-LWA

7 C303WABO31 RAWUNF ILTERED

8 C4OOWABO31 AS

9 C4OOWAB031 B

10 C4DOWAB031 BA

11 C4DOWABO31 CD

12 C4OOWABO3! CO

13 C4OOWABO $31 \mathrm{CU}$

14 C4OOWAB0 $31 \mathrm{CU}$

15 C40OWAB031 FE

16 C400WAB031 FE

17 C4OOWABO3I HG

18 C4OOWABO31 MN

19 C4OOWAB031 MN

20 C4DOWAB031 NI

21 C40OWAB031 PB

22 C4OOWABO3I PB

23 C40OWABO31 SE

24 C400WAB031 ZN

25 C4OOWABO3! ZN

26 C40OWABO32 $\mathrm{B}$

27 C40OWABO32 CL

(2B C40OWABO32 CL

29 C4DOWABO32 CL

30 C4OOWABO3E COND

31 C4OOWABO32 COND

32 C4DOWABO32 CO3

33 C4OOWABO32 CO3

34 C4OOWABO32 F

35 C4OOWAB032 F

36 C40OWABO32 $\mathrm{F}$

37 C4OOWABE $32 \mathrm{HCO} 3$

38 C40OWABO32 $\mathrm{HCO} 3$

39 C40OWABO32 $\mathrm{NH}_{4}$

I J C4OOWABO32 NH4

41 C4OOWABO32 NH4

42 C4OOWABO32 NO3

43 C4DOWABO32 NO3

44 C4OOWABO32 NO3

45 C40OWAB032 PH

46 C4DOWABO32 PH

47 C40OWABO32 $\mathrm{SO}_{4}$

48 C4OOWABO32 $\mathrm{SO}_{4}$

49 C4OOWABO32 $\mathrm{SO}_{4}$

50 C4OOWABO32 TOS

51 C4OOWABO32 TOS

52 C30IWABO33 ACIDIFIED HCL

53 C302WABO34 ACIDIFIED HNO3

54 C4OOWABO34 BA

55 C4OOWABO34 CALCIUM 92

56 C40OWABO34 CD

57 C4OOWABO 34 CO

58 C4COWABO34 CU

59 C40OWABO34 FE

GO C4OOWABO34 HG

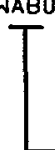

CANAL VAIL $4 /$ VAIL $4 A$

1.43 ???CBPLLW

???PHMLLW

8.3 ???TBTLLW

???VBFLLW

$.004 \quad$ ?P?COLGHT

$.35 \quad 14$. COLGHT

.12 20.AASGHT

?? ?ASPGHT

.005NDLAASGHT

.016 3??ASPGHT

.25 28.AASVET

.22 20. AASGHT

1.475 5.0AASVET

.0024 20.AASGHT

.0120. AASGHT

.1 40.AASVET

.027 .005 NDLAASGHT

.030 ???ASPGHT

.001 NDLCSPGHT

.010 20.AASGHT

1.14 3. OAASVET

16. COLGHT

19 5.3T ITLCH

199. ???AOAVET

200. 5.0TITGHT

1.6 2. OCBBVET

1650 . 3.0CBPGHT

13. 23.102VET

16.4 12. TITGHT

$\begin{array}{ll}.35 & 14 . \text { COLGHT }\end{array}$

$5530.121 \mathrm{VET}$

$.6 \quad 33$. ISELCH

140. 1.4 TITGHT

172. 1.7102VET

$.12^{.03}$ NDL TITGHT

.$^{12}$ NDLISEVET

4.4 NDLISEVET

.250. COLGHT

4.5 11. ISELCH

8.00 .

8.54 . 23 PHMVET

$.40 \quad 5.0 T I T L C H$

$335 . \quad 6.0$ GRAGHT

$385 . \quad 4.8156 \mathrm{VET}$

1090. 5.0148VET

052. 5.0GRAGHT

NOLAASLCH

2. $2 A A S L C H$

NDLAASLCH

NDLAASLCH

NDLAASLCH

NOLAASLCH

NOLAASLCH
GENTRY YOUNG

MMC

NUN

DGC

LIT

MPL

MPL

MPL

MPL

MPL

$M P L$
$M P L$
$M P L$

MPL

MPL

MPL

MPL

MPL

MPL

MPL

MPL

MPL

GPL

MPL

UMCCOMPENSATED TO $25 \mathrm{C}$

MPL

MPL

MPL

MPL

MPL

MPL

MPL

PPM

MPL

MPL

MPL

MPL

NUN

NUN

GPL

MPL

MPL

MPL

MPL

MPL

MPL

$M P L$

MPL

MPL

Site Code

Note: Samples are identified by WXYijk

where: $\quad W=$ LLL Water Quality Survey Program

$\mathrm{XY}=$ fixed site code

$i j=$ field trip designation

$\mathrm{k}=$ major aliquot: An asterisk (*) implies that the information

pertains to all $\mathrm{k}$. 
Table 10b. Output file 2.1 (Output of input-data set Table 10a.)

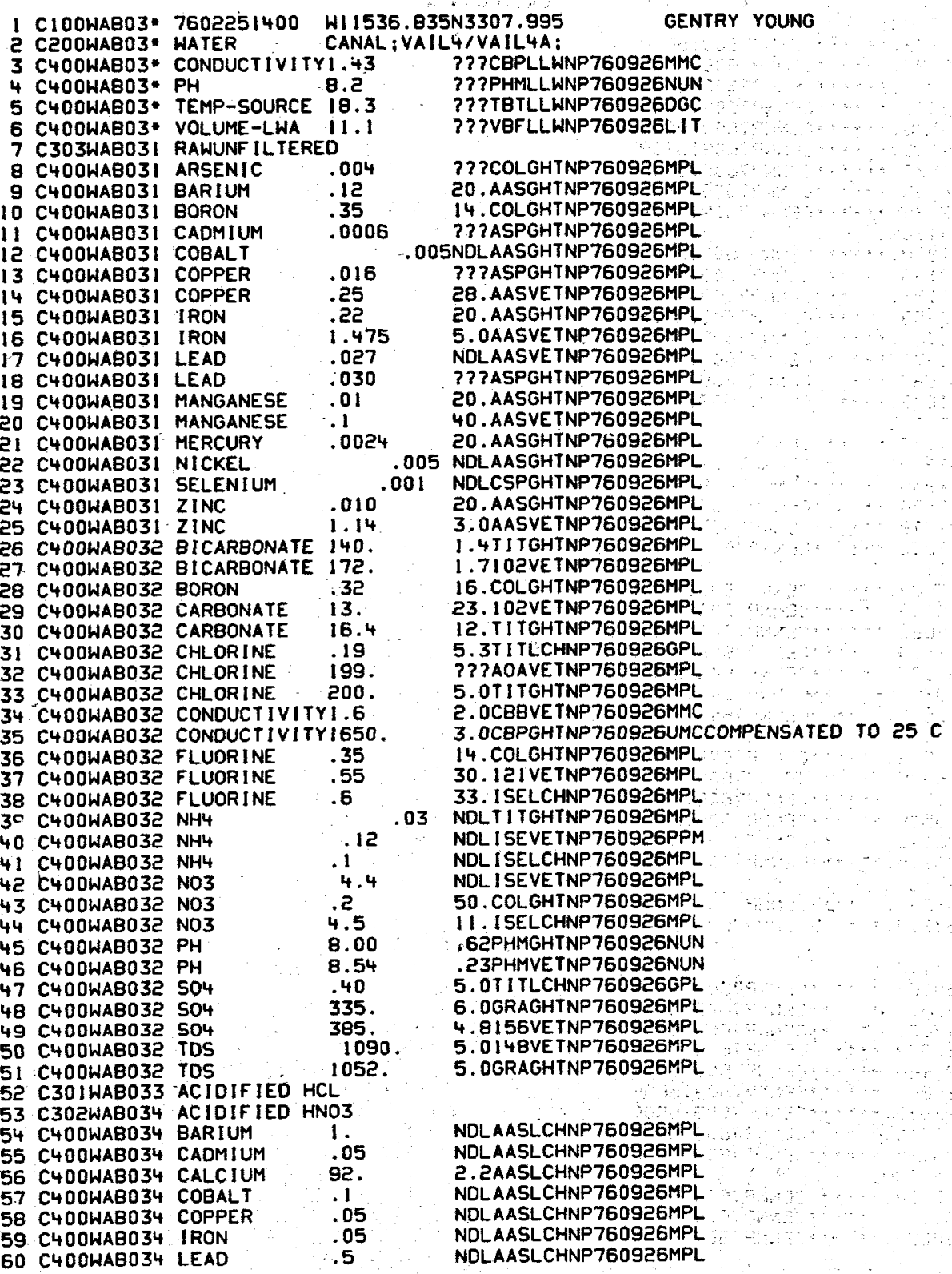

Note: 1) Preprocessor insertion of latitude/longitude information via the fixed-site code defined in Table 3.

2) Preprocessor insertion of the parameter via the synonyms defined in Table 5 . 
Table 1la. County social data (LLL Socioeconomic Program).

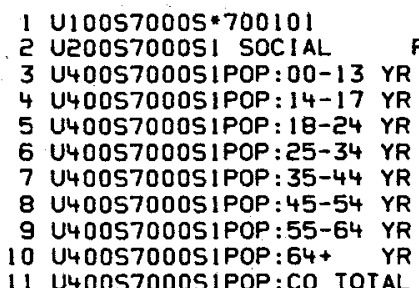

11 U400S7000SIPOP:CO TOTAL

12 U2005700052 SOCIAL

13 U4005700052POP:AMER-IND

14 U400S7000S2POP:BLACK

15 U400S7000S2POP:CHINESE

16 U400S7000S2POP:F ILIPINO

17 U400S7D00S2POP: JAPANESE

18 U400S7000S2POP:OTHER

19 U400S7000S2POP:SP-AMER

20 U40057000S2POP:WHITE

ट1 U200S7000S3 SOCIAL

22 U40057000S3ED-A: 00-07YR 23 U400S7000S3ED-A:08 YR 24 U400S7DDOS3ED-A:09-11YR 25 U40057000S3ED-A:12 YR 26 U400S7000S3ED-A: 13-15YR 27 U4005700CS3ED-A:16+ YR 28 U20057000S4 SOCIAL

29 U40057000S4IN-F: 00-04K\$ 30 U400S700054 IN-F: 04-06KS 31 U400S7000S4, IN-F:06-08KS 32 U40057000S4 IN-F:08-10KI 33 U400S7000S4 IN-F: 10-15KI 34 U400S7000S4 IN F : 15-25KS 35 U400S7000S4IN-F:25+ K\$ 36. U20057000S5 SOCIAL

37 U4005700055IN-I:00-04K\$ 38 U4005700055IN-I:04-06KI 3. U400S7000S5IN-I:06-08KS 40 U400S7000S5IN-1:08-10K9 41 U400S700055IN-I:10-15K 42 U4005700055IN-I:15+ KS 43 U200S7000S6 SOCIAL

44 U400S7000S6POVERTY:FAMS 45 U400S7000S6POVERTY: INDS 46 U100S7001S*700101

47 U2005700ISI SOCIAL

48 U400S7OOISIPOP:00-13 YR 49 U400S700ISIPOP: $14-17$ YR 50 U400S700 ISIPOP: $18-24$ YR 51 U400S7001SIPOP:25-34 YR 52 U400S700 ISIPOP: $35-44$ YR 53 U400S700ISIPOP:45-54 YR 54 U4005700 ISIPOP:55-64 YR 55 U400S7001SIPOP:64+ YR 56 U400S700ISIPOP:CO TOTAL 57 U2005700!S2 SOCIAL 58 U4005700 1 S2POP : AMER-IND 59 U400S700ISCPOP:BLACK 60 U4005700 IS2POP:CHINESE
POPULATION:

0500

CAL IFORNIA

5140376 *** *CENNP760915POP 1517023 ** * *ENNP7609I5POP $2424333 * *$ *CENNP760915POP $2664863 . * *$ *ENNP760915POP 2368576 ** * * CENNP760915POP 2324106 *** * CENNP760915POP $1711533 . * * *$ * CENNP7609I5POP $1806905 . * *$ *ENNP760915POP 9953134.** CENNP760915POP PPULATION:

$91018 * * *$ * CENNP760915POP $1400143 . * *$ *ENNP760915POP $170131 \ldots+$ CENNP760915POP $138859 * * * *$ *ENNP760915POP $213280 . * * *$ *ENNP760915POP $178671 * * *$ * *ENNP760915POP $3101589 . * *$ *ENNP760915POP $17761032 . * *$ CENNP760915POP EDUCAT ION:

1197277 * ***CENNP760915POP $953235 \ldots *$ * *ENNP760915POP $1911855 . * * *$ * CENNP760915POP 3566578.***CENNP760915POP $1784772 . * * *$ CENNP760915POP $1462266 . * *$ * *ENNP760915POP INCOME:

$619484 . * * *$ CENNP760915TAM $465188 . \ldots *$ CENNP760915F AM $558620 . * *$ *ENNP760915FAM $624520 . * *$ *ENNP760915F AM $1398973 * * *$ * CENNP760915FAM 1029394 . *** * CENNP760915FAM $305076 . * *$ CENNP7609 I5FAM NCOME :

329664 ****CENNP760915POP $316309 * *$ * CENNP750915POP $260871 . * *$ *ENNP760915POP 166534 ** *CENNP760915POP $175146 \ldots * *$ *ENNP760915POP $78975 * *$ * *ENNP760915POP POVERTY:

$421200 . * * *$ * CENNP760915POP $563218 . * * *$ * CENNP760915POP

POPULATION;

ALAMEDA

$260560 . * *$ *ENNP760915POP $76870 * *$ *ENNP760915POP $147101 . * * *$ CENNP760915POP $149779 . * * * *$ *ENNP760915POP $121426 . * * *$ *CENNP760915POP $125228 . \cdots *$ CENNP760915POP 92530.**** *ENNP760915POP $99710 . * *$ *CENNP760915POP $1073184 * * *$ *ENNP760915POP POPULATION:

5688.*** *CENNP760915POP $161282 . * *$ * *ENNP760915POP $20072 . * *$ * *ENNP760915POP

Note: County data is identified as SijmnAp

where: $\quad S=$ IVEP Socioeconomic Program

$i j$ = year for which the data applies

$\mathrm{mn}=$ county for which the data applies

$A=$ identifies Social, Fiscal, or Economic data type

$\mathrm{p}=$ data segment. An asterisk (*) implies the information pertains for all $p$ 
Table 11b. County fiscal data (LLL Socioeconomic Program).

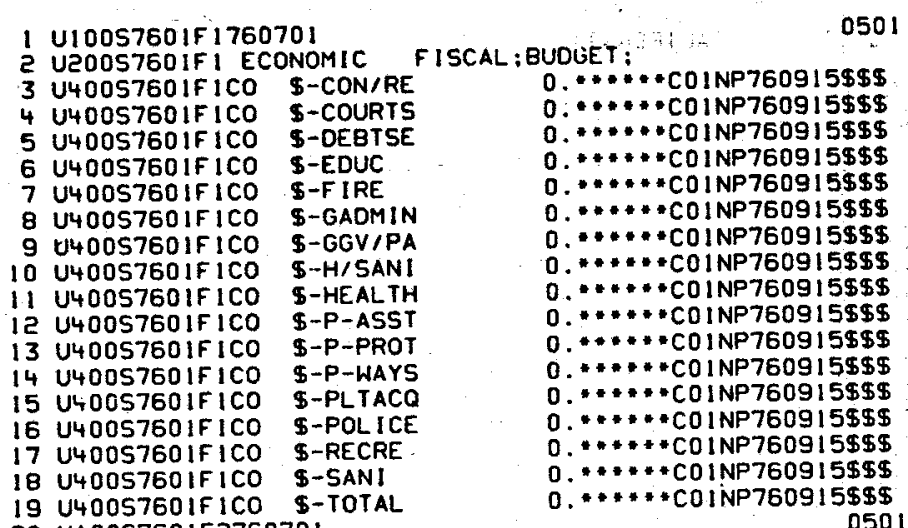

19 U400S760IFICO \$-TOTAL

20 U10057601F2760701

FISCAL:PC-BUDGET:

0501 ALAMEOA

21 U200S7601F2 ECONOMIC

23 U4005760IF2COPCS-COURTS

24 U40057601F2COPCS-DEBTSE

25 U4005760 IF 2 COPCS-EDUC

26 U4005760IF 2COPCS-FIRE

27 U400S760IF 2COPCS-GADMIN

28 U40057601F2COPCS-GGV/PA

29 U400S760IF2COPCS-H/SANI

30 U4005760IF2COPCS-HEALTH

31 U400S760 IF 2 COPCS-P-ASST

32. U400S7601F2COPCS-P-PROT

33 U40057601F2COPCS-P-WAYS

34 U40057601F2COPC\$-PLTACQ

35 U400S7601F2COPCS-POLICE

36 U400S760IF CCOPCS-RECRE

37 U400S760IF CCOPCS-SANI

38 U400S760IFZCUPCS-TOTAL

23 U10057602F 1760701

40 U20057602F I ECONOMIC

41 U400ST602F ICO \$-CON/RE

42 U400S7602F ICO \$-COURTS

43 U400S7602F ICO \$-DEBTSE

44 U400S7602F ICO \$-EDUC

45 U40GS7602F ICO \$-FIRE

45 U400S7602F ICO \$-GADMIN

47 U400S7602F ICO \$-GGV/PA

48 U40057602FICO \$-H/SANI

49 U400S7602F ICO \$-HEALTH

50 U40057602F ICO \$-P-ASST

51 U400S7602F ICO \$-P-PROT

52 U400S7602F ICO \$-P-WAYS

53 U40057602F1CO \$-PLTACO

54 U400S7602FICO \$-POLICE

55 U400S7602F ICO S-RECRE

56 U400S7602F ICO \$-SANI

57 U400S7602F ICO \$-TQTAL

58 U10057602F276070I

PC... COINP760915\$\$\$

$0 . \ldots *$ COINP760915\$\$S

$0 . . . . . . C O I N P 760915 \$ \$ \$$

0...**COINP760915\$\$\$

$0 . \cdots+C 01 N P 760915 \$ \$ \$$

$0 . * * *$ COINP760915\$\$\$

$0 . \cdots \cdots+C 01 N P 760915 \$ \$ \$$

$0 . * \ldots *$ COINP760915\$\$E

$0 . * * *$ *COINP760915\$\$\$

$0 \ldots \ldots$ COINP760915\$\$\$

0.*.... COINP760915\$\$\$

$0 . \ldots \ldots$ COINP760915\$SS

0.*..**COINP760915\$\$S

D.***COINP760915\$\$S

$0 \ldots \ldots$ COINP760915\$\$\$

0....... C01NP760915\$\$\$

$0 . * *$ * *OINP760915\$\$\$

ALAMEDA

ISCAL : BUDGET

$0502 \quad$ ALPINE

59 U200S7602F2 ECONOMIC

60 U400S7602F 2COPC\$-CON/RE

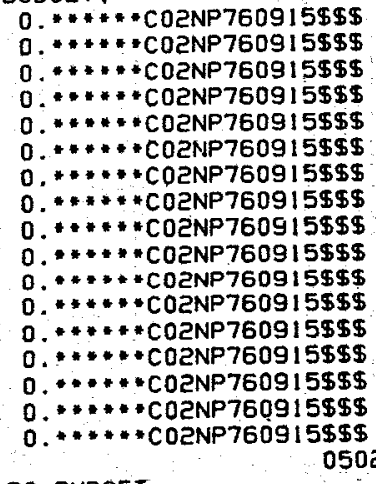

Note: County data is identified as SijmnAp

where: $\quad S=$ IVEP Socioeconomic Program

$i j=$ year for which the data applies

$\mathrm{mn}=$ county for which the data applies

$A=$ identifies Social, Fiscal, or Economic data type

$p=$ data segment. An asterisk (*)

implies the information

pertains for all $p$ 
Table 11c. County economic data (LLL Socioeconomic Program).

PAGE

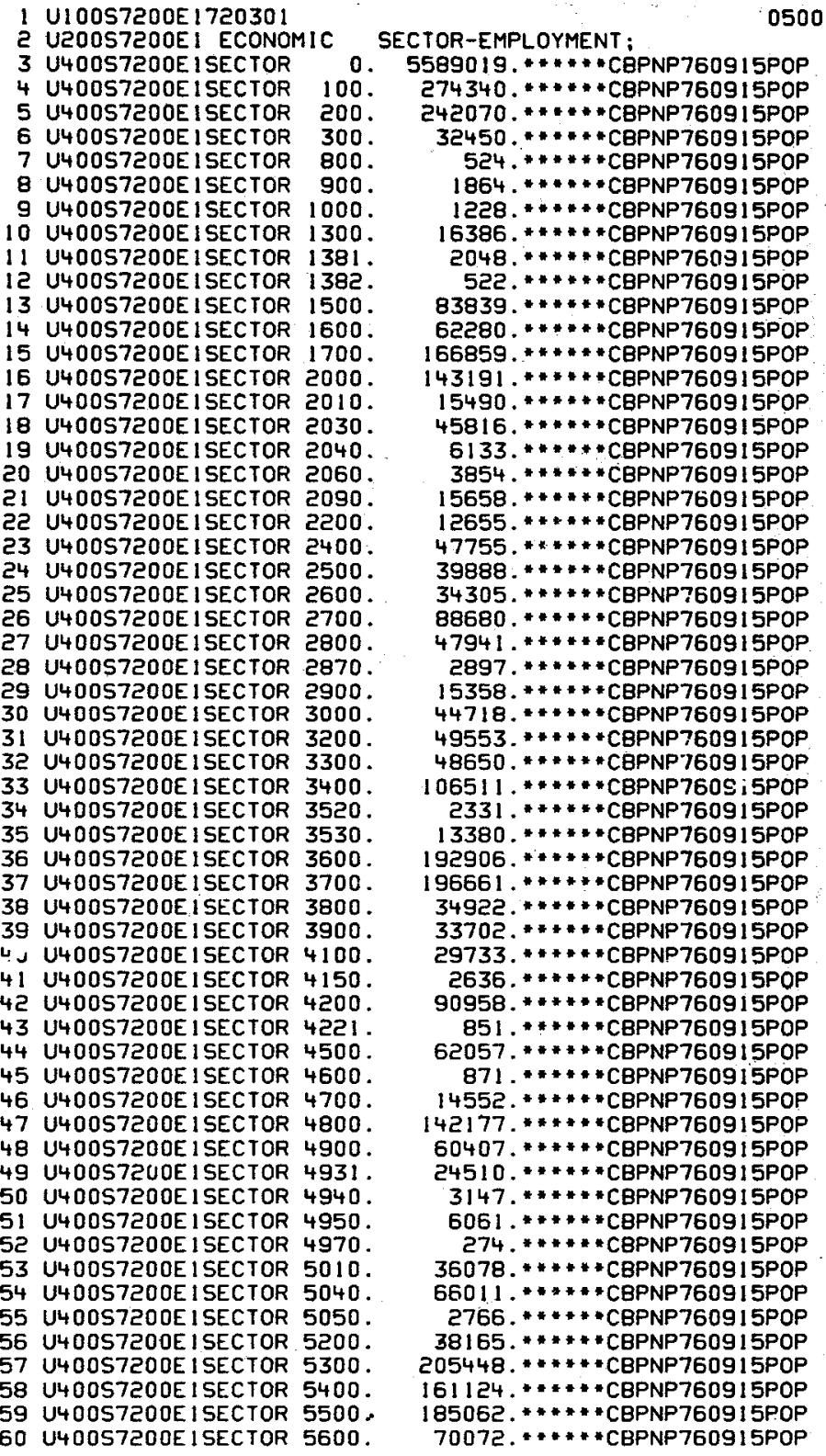

Note: County data is identified as SijmnAp

where: $\quad S=$ IVEP Socioeconomic Program

$i j=$ year for which the data applies

$\mathrm{mn}=$ county for which the data applies

$A=$ identifies Social, Fiscal, or Economic data type

$\mathrm{p}=$ data segment. An asterisk (*)

implies the information

pertains for all $\mathrm{p}$.

CALIFORNIA 
Table 12. Soil-sample data (LLL Ecological Systems Survey Program).

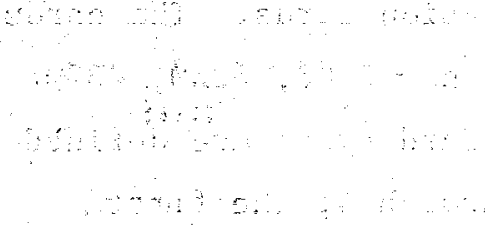

4648 U100VKSOOIA760203 4649 UEOOVKSOOIASOIL 4650 U399VK500 IAKAAD $341 \mathrm{~V}$ 4651 U4OOVKSOOIAALUMINUM 4652 U4 OOVKSOOIAANTIMONY 4653 U4 OCVKSOOIAARSENIC 4654 U4OCVKSOOIABARIUM 4655 U4DOVKSOOIABROMINE 4656. U4OOVKSOOIACALCIUM 4657 U4OOVKSOOIACERIUM 4658 U40OVKSOOIACESIUM 4659 U4OOVKSODIACHROMIUM 4660 V4OOVKSOO IACOBALT 4661 U40OVKSO01ADYSPROSIUM 4662 U4DOVKSOO I AEUROPIUM 4653 U40OVKSO0IAGALLIUM 4664 U4DOVKSOOIAHAFNIUM 4665 U4OOVKSOOIAIRON 4666 U400VKS001ALANTHANUM 4667 U4OOVKSOOIALUTETIUM 4668 U4DOVKSOOI AMAGNES IUM 4669 U400VKSODIAMANGANESE 4670 U4ODVKSOOI ANEOOYMIUM 4671 U40OVKSDO IAPOTASSIUM 4672 U4OOVKSOOIARUBIDIUM 4673 U40OVKSOOIASAMARIUM 4674 U4DOVKSOOIASCANDIUM 4675 U4DOVKSODIASODIUM 4676 U4DOVKSODIASTRONT IUM 4677 UHDOVKSOOIATANTAL UM 4678 U4DOVKSOOIATERBIUM 4679 U4DOVKSOOIATHORIUM 4680 U40OVKSOOIATITANIUM 4681 U4DOVKSOOIATUNGSTEN 4682 U4 DOVKSOOI AURANIUM 4683 U4OOVKSOOIAVERADIUM 4684 U4OOVKSOOIAYTTERBIUM 4685 U40OVKSOOIAZINC 46F 3 U4OOVKSODIAZIRCONIUM 4687 U100VKS001B760203 4688 UZOOVKSOO IBSOIL 4689 UIOOVKSO02A760203 4690 U20OVKSODZASOIL 4691 U399VKSO02AKAAO35I 4692 U4DOVKSODZAALUMINUM 4693 U4OOVKSODZAANT IMONY 4694 U4OOVKSOOZAARSENIC 4695 U400VKSO02ABARIUM 4696 U400VKSOOZABROMINE 4697 U4DOVKSOOZACALCIUM 4698 U4DOVKSODZACERIUM 4699 U400VKSODZACESIUM 4700 U4 OOVKSOOZACHLORINE 4701 U4OOVKSOOZACHROMIUM 4702 U40OVKSODZACOBALT 4703 UUDOVKSODZADYSPROSIUM 4704 U4OOVKSOOEAEUROPIUM 4705 U400VKSOOZAGALLIUM 4706 U400VKSOOZAHAFNIUM 4707 U4OOVKSOOZAINDIUM
003 ALFALFA;ORY;0D3; COLLECT-PLANT: IS13E27N IVS150I VKSODIA $5.703 E+04$ ASDMTOLCHNP76092600IKAAO34 FINXKAAOI $3.139 E+03$ 8. 263E-DIASOMTDLCHNP76092600IKAA034 9.323E+ OOASDMTDLCHNP760925001KAA034 $4.883 E+02 A S D M T D L C H N P 760926001 K A A 034$ $0.000 E+0$ OASDMTDLCHNP76UB26001KAAD34 $5.039 E+04$ ASDMTDLCHNP760926001KAAD34 6.582E+ 01 ASDMTOLCHNP76092600IKAAO34 $7.239 E+00 A S D M T D L C H N P 760926001 K A A 034$ $4.723 E+01$ ASDMTDLCHNP760926001KAAO34 1.030E+0I ASDMTDL CHNP.76092600IKAA034 4. 396E+ O0ASDMTOLCHNP760926001KAAO34 8 91 3E-DIASDMTOLCHNP760926001KAA034 1. $997 E+01$ ASDMTOLCHNP760926001KAA034 4.869E+ DOASDMTOLCHNP76092600IKAAD34 2.727E+04ASDMTDLCHNP76092600 1 KAAD 34 $3.471 E+01$ ASDMTOLCHNP760926001KAA034: 5.653E-D 1 ASDMTDLCHNP760926001KAA034 $0.000 E+00 A 5 D M T O L C H N P 760926001$ KAAO 34 4.681E+02ASDMTDLCHNP760926001KAAO34 $2.976 E+01$ I ASDMTDLCHNP76092600 IKAAD 34 $1.814 E+04$ ASDMTOLCHNP760926001KAAO34 $1.192 E+02 A S D M T O L$ CHNP760926001KAAO34 $5.514 E+00 A$ SDMTDLCHNP760926001KAAO34 9.888E+ DOASOMTDLCHNP760926001KAAD34 5. $242 E+03 A S D M T D L C H N P 760926001 K A A 034$ $2.531 E+02 A 50 M T D L C H N P 760926001 K A A 034$ 1. 079E+00ASDMTOLCHNP760926001KAA034 6. B20E-0 1 ASDMTDLCHNP76092600 1 KAA034 $1.059 E+01$ ASOMTDLCHNP76092600 IKAA034 $3.579 E+03$ ASDMTDLCHNP76092600 IKAA03 9,761E-01ASOMTOLCHNP760926001KAA034 3. $233 E$ + DOASOMTDLCHNP760926001KAAD34 5.816E+OIASDMTDLCHNP7609260CIKAA034 2.649E+00ASDMTOLCHNP76092600IKAA034 8.353E+0 IASDMTDLCHNP760926001KAA034 1. 199E+02ASDMTOLCHNP760926001KAA034 FINXKAAO 1 - $9.876 E-02$ FINXKAAO 1 6.899E-0 FINXKAAOI $2.2 B 9 E+0$ FINXKAAOI $1.617 E+00$ F. NXXKAAOT $5.648 E+03$ FINXKAAOI $1510 E+00$ FINXKAAOI $1.373 E-01$ FINXKAAOI $1.447 \mathrm{E}+00$ FINXKAAOI 2.158E-01 FINXKAAOI 1.349E-0I FINXKAAOI $2.473 E-02$ FINXKAADI $5.511 E+00$ FINXKAAOI 1.166E-OI FINXKAADI 2.927E+02 FINXKAADI 5.256E-0 1 FINXKAAOI $3.714 E-02$ FINXKAAOI $5,318 E+04$ FINXKAAD! $3: 796 E+00$ FINXKAADI $1.879 E+00$ FINXKAAO 1 1.068E+03 FINXKAAD $14.170 E+00$ FINXKAADI 2.134E-01 FINXKAAOI $7.960 E-02$ FINXKAAD 1 5.992E+0I FINXKAADI 5.732E+OI FINXKAADI $7.124 E-02$ FINXKAAOI 5.1B3E-02 FINXKAAOI 1.682E-0I FINXKAAO I 1.235E+03 FINXKAADI 7.487E-DI FINXKAAOI $1919 E-01$ FINXKAADI $2.36 I E+0 I$ FINXKAADI 1.06IE-0I FINXKAAOI 7.120E+DO FINXKAAOI 4.966E+0! ALFALFA : ORY; 306 ; COLLECT-PLANT;

BARE; DRY CRUST : 003 : OOJ IIS13E330 IVS150Z

502 0-3INCH SOIL VKSOOZA

5.480E+04ASOMTDLCHNP760926001 KAA035 8.922E-0 IASOMTOLCHNP760926001KAA035 9.289E+00ASDMTDLCHNP76092600 IKAA035 $4.730 E$ + 02ASDMTOLCHNP76092600 IKAA035 $0.000 E+00 A$ SDMTDLCHNP76092600 IKAA035 $5.284 E+04$ ASDMTDLCHNP76092600 IKAA035 $6.844 E+01$ I SDMTOLCHNP76092600 IKAA035 7.295E+00ASDMTOLCHNP76092600.1 KAA035 8.923E+02ASDMTDLCHNP76092600 1 KAA035 4.881E+ O I ASOMTDLCHNP76092600 IKAA035 $1.057 E+01$ ASOMTDL CHNP760926001KAA035 4. $243 E+00 A S O N T T L C H N P 760926001$ KAAO35 9.245E-0 IASDMTDLCHNP76092600 IKAAD35 $2.414 E+01$ ASDMTOLCHNP76092600 IKAA035 $5.441 E+00 A 50 M T D L C H N P 760926001 K A A 035$ 1. 124 E-DIASDMTDLCHNP76092600 IKAA035
FINXKAAOI $1.426 E+03$ FINXKAAOI 9 127E-02 FINXKAAO 1 4.273E-01 FINXKAAOI $2.932 E+0 I$ FINXKAAOI $1.534 E+00$ FINXKAAOI $1.544 E+03$ FINXKAAOI $2.054 E+00$ FINXKAAOI 1.306E $\div 01$ FINXKAADI $711 E+00$ FINXKAAO1 1.898E-01 FINXKAAOI 1 910E-01 - FINXKAAOI 2.576E-02 FINXKAAOI $3.765 E+00$ FINXKAAOI $1.249 E-01$ FINXKAAOI 1. 103E-01 FINXKAAOI 1.5B5E+02

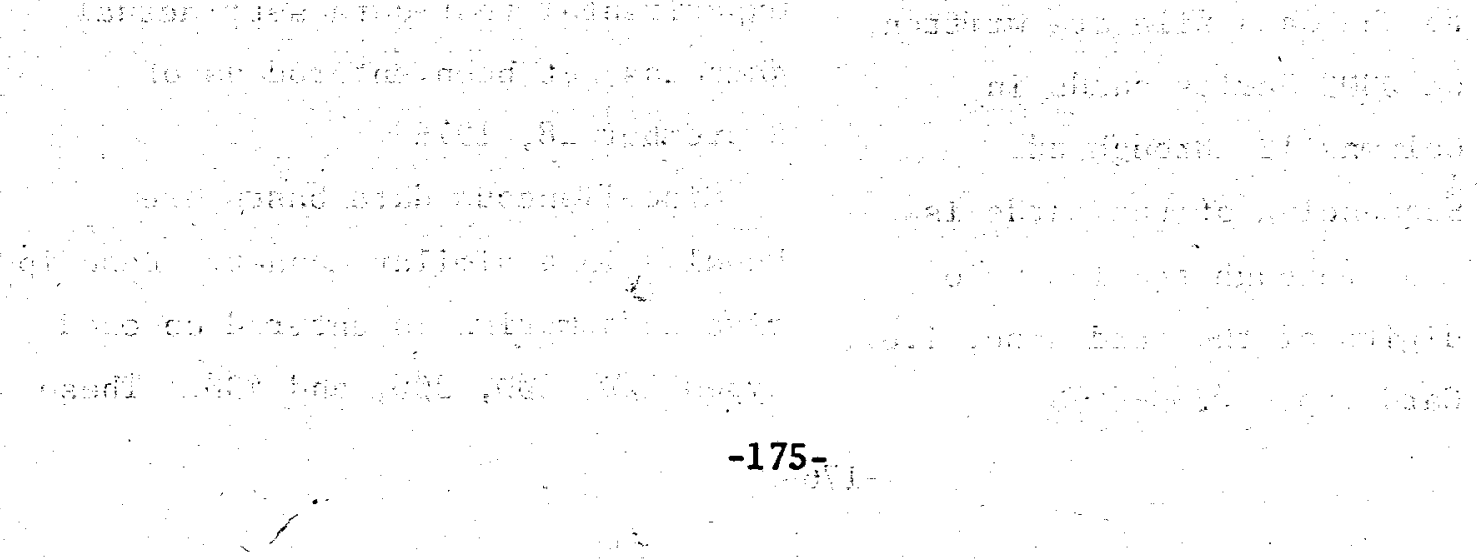


Associated with each data file is a set of information cards. The cards are of four types - $\emptyset 1 \emptyset \emptyset, \emptyset 2 \emptyset \emptyset, \emptyset 3 \emptyset \emptyset$ Series, $\emptyset 4 \emptyset \emptyset$. Card types are defined in Columns 1 through 4; the first seven characters of the fixed-sitedata file $A^{* * Y M D D m d d}$ resides in Columns 5 through 11 on all card types.

Card Type $\emptyset 1 \emptyset \emptyset-$ Cols. 12-14: contain the last three characters of the fixed-site-data file $A^{* * \text { YMDDmdd. }}$

Cols. 15-17: always contain asterisks $(* * *)$.

Co1s. 43-50: contain the aboveground level at which data were collected. Units are decimal-meters.

Card Type $\emptyset 2 \emptyset \emptyset$ - There exists one or more type $\emptyset 2 \emptyset \emptyset$ cards for each data file.

Cols. 12-23: contain the data type - METEOROLOGIC or GAS.

Cols. 24-8Ø: contain the spacecomma-, or semi-colondelimited parameters associated with the data type defined.

Card Type $\emptyset 3 \emptyset \emptyset$ Series - All noteworthy comments pertaining to the data file are written on $\emptyset 3 \emptyset \emptyset$ Series cards in Columns 12 through $8 \emptyset$. Sequencing of the cards is made through the last two digits of the card type, i.e., Card Types $\emptyset 3 \emptyset \emptyset-\emptyset 399$.
Card Type $\emptyset 4 \emptyset \emptyset$ - Card Type $\emptyset 4 \emptyset \emptyset$ is a data-format-description card. There exists one type $\emptyset 4 \emptyset 0$ card for each parameter written into the data file. Cols. 12-23: contain the parameter name.

Cols. 34-36: contain the percent error associated with that parameter.

Cols. 37-39: contain the code of the method used to measure that parameter.

Cols. 40-42: contain the code of the Laboratory that is responsible for those data values.

Cols. 51-53: contain the code of the unit in which the data are reported.

Cols. 54-8Ø: remark on the columns and format in which the data is written, for example: ASCII F1Ø.3 in $21-3 \emptyset$.

This set of information cards per data file contribute to the contents of an index file that does conform with the IVEP Data-Base Plan. Table 13 contains information related to an experimental test-data set; actual data has not been entered as of September 28, 1976.

Miscellaneous data bases are handled in a similar manner. Descriptive information is entered on card types $1 \emptyset \emptyset, 2 \emptyset \emptyset, 3 \emptyset \emptyset$, and $4 \emptyset \emptyset$. These 
cards are then entered into an index file of all miscellaneous data bases. Table 14 is an up-to-date listing of that file.

\section{Data Management}

The usual problem of data storage assoclated with large data bases is of no real significance on the octopus System at the Lawrence Livermore Laboratory. The IBM Photostore, one component of the system, provides sufficient avallable storage with rapid access and modest reliability at a cost-effective price. However, data-handling problems related to manipulation, selective retrieval, analysis, and display are problems that will plague this project. For this reason, action has been taken to evaluate the long-term solution to data-management needs of the IVEP.

An investigation into the avai1ability of a data-base-management system compatible with LLL's computer facility and capable of providing such desirable features as subfile extraction, concurrent retrleval, etc. has thus far led to consideration of the following software packages:

1. Master Control - developed by Lawrence Livermore Laboratory

2. Feudal - developed by Lawrence Livermore Laboratory

3. System 2000 - developed by MRI Corp. of Austin, Texas

As yet, no formal assessment of the above candidates has been made. It is, however, generally agreed upon that Feudal will be experimentally implemented because of its avallability and low overhead cost.

Until any one data-base-management system is extensively tested by IVEP researchers, it will not be accepted as the official operating system.

At this time, data storage continues to make use of the Photostore. Retrieval is made possible through several multipurpose Fortran codes. Data manipulation and analysis require special purpose programs.

The availability of geocoded software packages for data display has also been investigated. Information is currently being gathered on all known avallable systems. 
Tab1e 13. Index file to air-quality data (LLL Air Quality Survey Program).

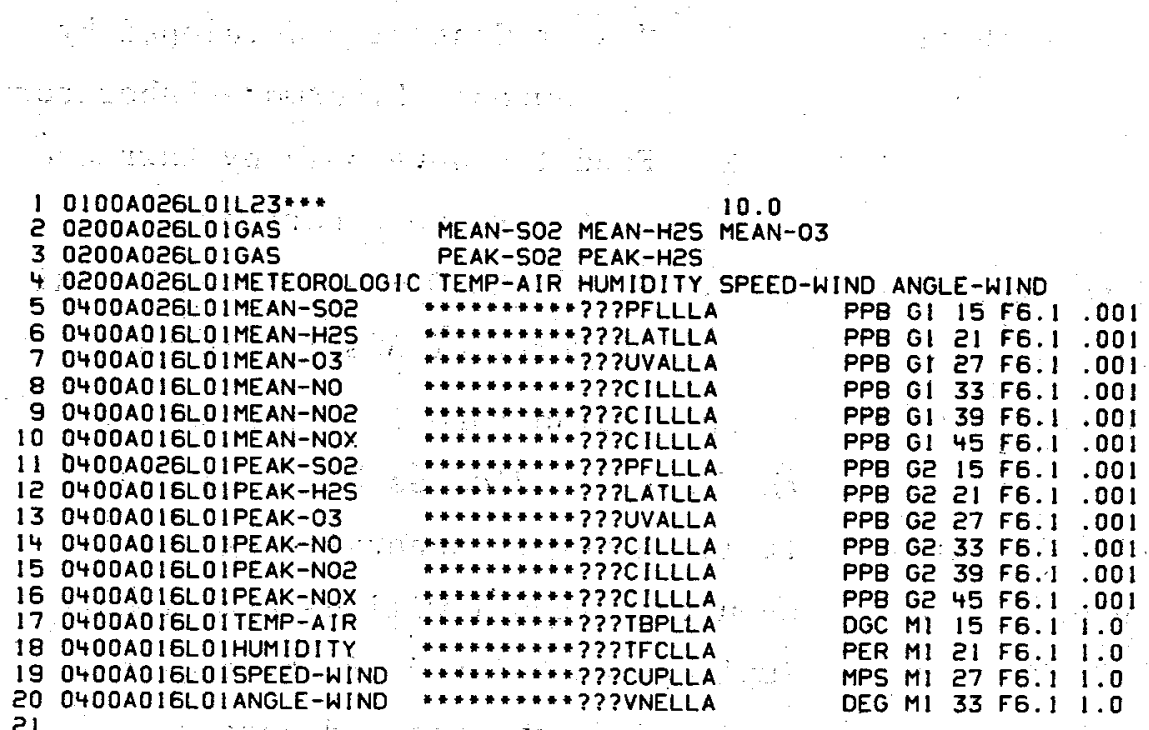


Table 14. Index file to miscellaneous data bases.

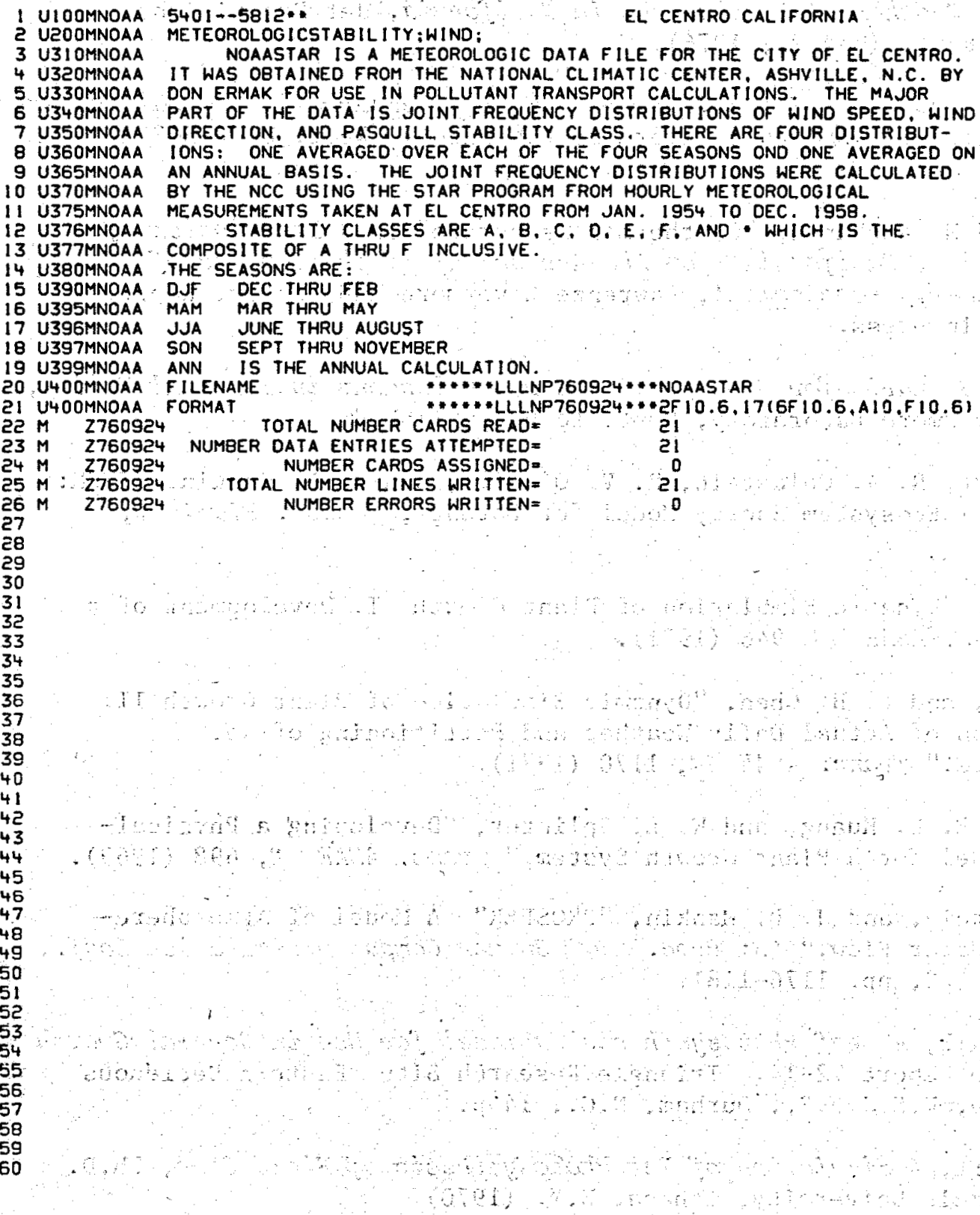




\section{References}

1. D. W. Layton and D. L. Ermak, Eds., A Description of Imperial Valley, California, for Assessment of the Impacts of Geothermal Energy Development; Lawrence Livermore Laboratory, Rept. UCRL-52121, in press.

2. C. Davis, D. J. Kerrisk, L. Leibowitz, and K. K. Tang, Preliminary Scenario for Geothermal Development in California, Jet Propulsion Laboratory, Rept. (May 21, 1976).

3. D. Towse, An Estimate of the Geothermal Energy Resource in the Salton Sea Trough, California, Lawrence Livermore Laboratory, Rept. UCRL-51851 (1975).

4. D. Ermak and M. Buchanan, "Geothermal Resources" in A Description of Imperial Valley, California, for the Assessment of the Impacts of Geothermal Energy Development, Lawrence Livermore Laboratory, Rept. UCRL-52121, in press.

5. D. Ermak, A Scenario for Geothermal Power Development in Imperial Valley, Lawrence Livermore Laboratory, Rept. to be published.

6. H. H. Shugart, R. A. Goldstein, R. V. O'Neill, and J. B. Mankin, "TEEM: A Terrestrial Ecosystem Energy Model for Forests," Decol. Plant. 9, 231 (1974).

7. R. B. Curry, "Dynamic Simulation of Plant Growth. I. Development of a Mode1," Trans. ASAE 14, 946 (1971).

8. R. B. Curry, and L. H. Chen, "Dynamic Simulation of Plant Growth II. Incorporation of Actual Daily Weather and Partitioning of Net Photosynthate," Trans. ASAE 14, 1170 (1971).

9. L. H. Chen, B. K. Huang, and W. E. Splinter, "Developing a PhysicalChemical Model for a Plant Growth System," Trans. ASAE 12, 698 (1969).

10. R. A. Goldstein, and J. B. Mankin, "PROSPER" A Model of AtmosphereSoil-Plant Water Flow," in: Proc. 1972 Summer Computer Simulation Conf., San Diego, 1972, pp. 1176-1181.

11. T. R. Sinclair, A Leaf Photosynthesis Submodel for Use in General Growth Models, Memo Report 72-14. Triangle Research Site, Eastern Deciduous Forest Biome, U.S.J.B.P., Durham, N.C., 14 p.

12. D. W. Stewart, A Simulation of Net Photosynthesis of Field Corn, Ph.D. Thesis, Cornell University, Ithaca, N.Y. (1970).

13. J. H. M. Thornley, and J. D. Hesketh, "Growth and Respiration in Cotton Balls," J. Appl. Ecol. 9, 315 (1972).

14. J. H. Bennet, and A. C. Hill, "Inhibition of Apparent Photosynthesis by Air Pollutants," J. Environ. Qual. 2, 526 (1973). 
15. California State Water Resources Control Board, Water Quality Control Policy on the Use and Disposal of Inland Waters Used for Power Plant Cooling, (1975).

16. Modesto Properties Co. v. State Water Rights Bd., 1960, 4 Cal. Rptr. 226, 179.C.A.2d 856 .

17. J. C. Wharton and D. W. Layton, "Geothermal Laws," in Description of Imperial Valley, California, for the Assessment of the Impacts of Geothermal Energy Development, Lawrence Livermore Laboratory; Rept. UCRL-52121 (in press).

18. 30 U.S. Code, Sec. 1001 et seq.

19. 30 U.S. Code Sec. 181 et seq.

20. 30 U.S. Code Sec. 1002 .

21. 30 U.S. Code Sec. 1014.

22. 30 U.S. Code Sec. 1020.

23. California Public-Resources Code Sec. 6903.

24. Section 3742.2. Californta Public Resources Code Sec. 3742.2.

25. California Water Code Sec. 13710, Division 7.

26. 42 U.S. Code Sec. 4321 et seq.

27. J. C. Wharton, Judicially Enforceable Substantive Rights Under NEPA, Lawrence Livermore Laboratory, Rept. UCRL-51828 (1975).

28. J. C. Wharton and M. Lewis, Legislative History of the Califormia Environmental Quality Act, Lawrence Livermore Laboratory, Preprint UCRL-78262 (1976).

29. U.S. Code of Congressional and Administrative News, 1970, pp. 5128-5131.

30. California Public Resources Code Sec. 25541.

31. California Pubilic Resources Code Sec. 25120.

32. A. D. Busse and J. R. Zimmerman, User's Guide for the Climatological Dispersion Model, Environmental Protection Agency, Rept. R4-73-024 (1973).

33. D. L. Ermak, "An Analytical Model for Air Pollutant Transport and Deposition from a Point Source," Atmos. Environ., in press.

34. R. Lange, ADPIC, A Three-Dimensional Computer Code for the Study of Pollutant Dispersal and Deposition Under Complex Conditions, Lawrence Livermore Laboratory, Rept. UCRL-51462 (1973). 
35. M. C. McCracken, User's Guide to the LIRAQ Model: An Air Pollution Model for the San Francisco Bay Area, Lawrence Livermore Laboratory, Rept. UCRL-51983 (1976).

36. R. E. Meyers and R. T. Cederwa11, "BNL Transport Mode1," in Regional Energy Studies Annual Report, Brookhaven National Laboratory, Rept. BNL-50478 (1975).

37. M. H. Dickerson, A Three-Dimensional Mass-Consistent Atmospheric Flux Model for Regions with Complex Topography, Lawrence Livermore Laboratory, Preprint UCRL-76157 (1975).

38. J. W. Knapp, and F. L. Leistritz, "Water for Energy in the Yellowstone River Basin and Adjacent Coal Areas," presented at the Twelfth Am. Water Resources Conf., Chicago, Illinois, Sept. 21, 1976. 


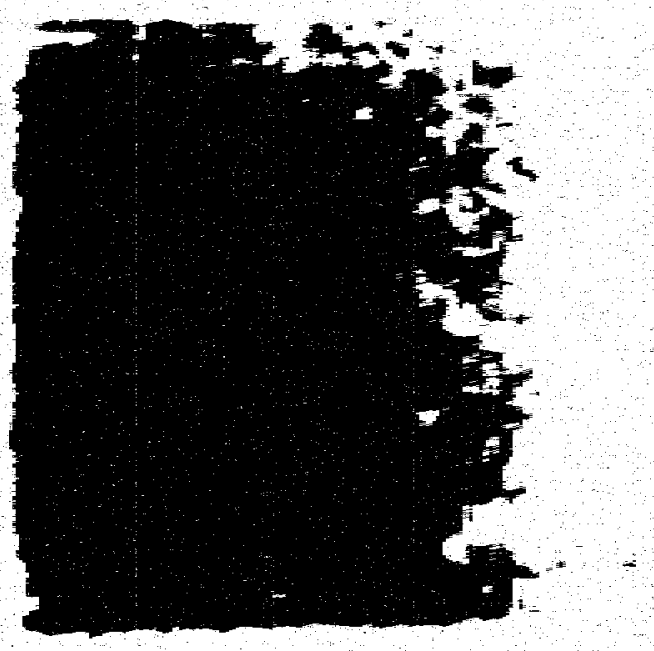




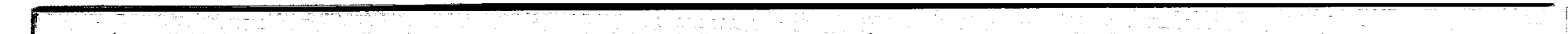


IMPERIAL VALLEY ENVIRONMENTAL PROJECT

Remote Sensing 
REMOTE SENSING

Thomas D. Palmer

The Imperial Valley Environmental Project (IVEP) is currently receiving remote sensing support from EG\&G, Inc., Las Vegas, Nevada, for continuing projects in the Salton Trough area. Support activities are under the direction of Project Scientist, Jerry Lackey. EG\&G airborne remote sensing capabilities provided under this support are summarized as

\section{fo1lows:}

- Conventional color and black and white photography at low to high altitude using fixed wing aircraft.

- Multispectral aerial photography using four band camera systems mounted on fixed-wing aircraft.

- Airborne radiometric surveys using fixed-wing or helicopter aircraft.

- Thermal infrared mapping at various wavelengths from fixed-wing aircraft.

- A flying platform for guest experiments such as airborneparticulate sampling.

Direct support to the IVEP consists of the following activities:

\section{Airborne Sampling:}

The Air Quality element of the IVEP is preparing to utilize EG\&G aircraft and air-collection equipment to collect gas and particulate samples over Imperial Valley.
Results are of interest to Imperial Valley meteorology-modeling activities in progress. Additionally, EG\&G is preparing to conduct airborne remotesensing flights to evaluate vertical concentrations of airborne pollutants such as plumes generated at geothermal test sites.

\section{Airborne Radiometric Survey}

Various elements of the IVEP are planning to utilize information derived from airborne surveys, such as mapping brine-intrusion areas and definition of geological features. EG\&G has completed a low-level detailed survey of the Niland geothermal test site and plans to survey other geothermal test sites throughout the Imperial Valley in the Heber, East Mesa, and Brawley areas. The survey of the East Mesa area will be completed by January 1977 and the other areas will be done later in the year. EG\&G is preparing to evaluate effluent-source terms for geothermal test sites utilizing helicopter aircraft to monitor test-site plume distribution. This work will coincide with the first scheduled continuous operation of the San Diego Gas \& Electric test site.

\section{Airborne Photography}

EG\&G has completed large-format photography of the entire Salton Trough area including the Coachella 


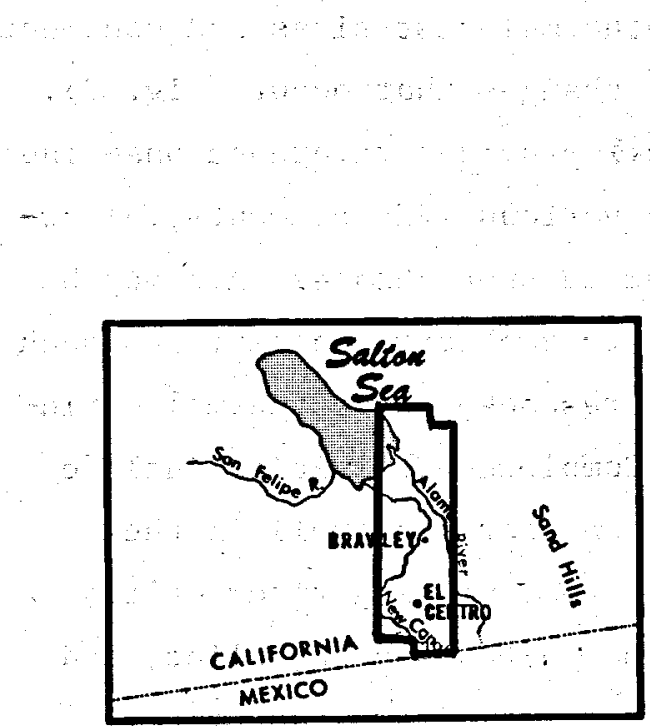

FLIGHT PATH LOCATION

Fig. 1. A representative "shingle" of large-format photography available for the Imperial Valley area. 
Valley, Salton Sea, Imperial Valley, East Mesa, and West Mesa areas

(Fig. 1). These photographs have been used to prepare a large, highaltitude, color mosaic map of the entire area. This photographic map is being utilized by IVEP elements for regional reference work. Largeformat photography is also being conducted on a site-designated basis to provide working base maps at a 1:24,000 scale. These maps are of particular value in mapping various baseline data such as croplands, refuge areas, irrigation systems, and general 1and-use patterns.

Large-format photography is of high value to the IVEP as a documentation tool to periodically record natural and cultural changes surrounding specific geothermal sites. EG\&G is periodically producing highresolution photographs of operating geothermal sites and various other sites of interest. Oblique photography will also be provided of the six IVEP meteorology stations, the San Diego test site, Mosquite Lake, Brawley test site, Heber test site, East Mesa test site, and the USDA Brawley field station.

Thermal Imaging

EG\&G has provided images of specified areas in the Imperial Valley, using thermal infrared technology for the purpose of mapping existing thermal conditions surrounding geothermal test sites and documenting any changes that occur (Fig. 2). This work provides reference baseline data to various IVEP elements, allowing them to spot changes that may be related to geothermal activities such as crop response to geothermal effluents. Completed activities include imaging an operating we11 in the Brawley area, mapping river deltas along the Salton Sea shoreline, and imaging the San Diego test site. Future work will involve a periodic resurvey of the same areas. EG\&G will also provide single thermal images of the Mesquite Lake area to determine fault-line location and of Salton Sea circulation patterns to determine temperature-distribution patterns and identification.

\section{Mu1tispectral Imaging}

EG\&G has completed imaging of several geothermal test sites in the Niland and Brawley areas using multispectral photography. This work has provided baseline reference data for IVEP studies that require a knowledge of normal crop and seasonal changes in lands surrounding geotherma1 test sites. Response by plants to geothermal pollutants can be determined by comparison to original photos (Fig. 3). This type of basic multispectral documentation will be conducted at other Valley-wide 


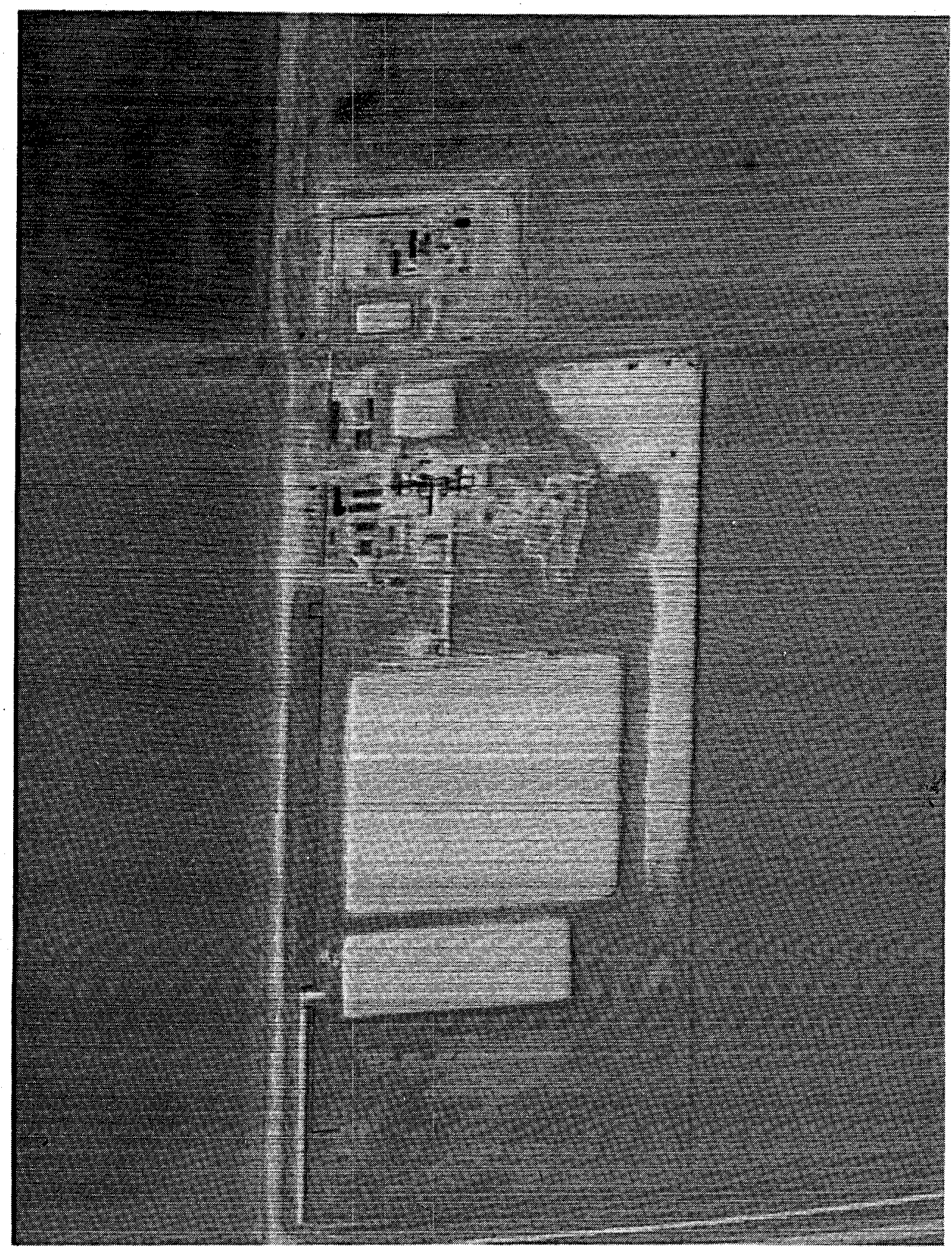

Fig. 2. Thermal infrared imagery of the SDG\&E/ERDA Geothermal Loop Test Facility near Niland, California. Light areas (cool) correspond to the brine holding ponds, spray pond, settling pond, and at the right to flood waters resulting from heavy rains. Dark areas (hot) correspond to buildings and various pipelines. 


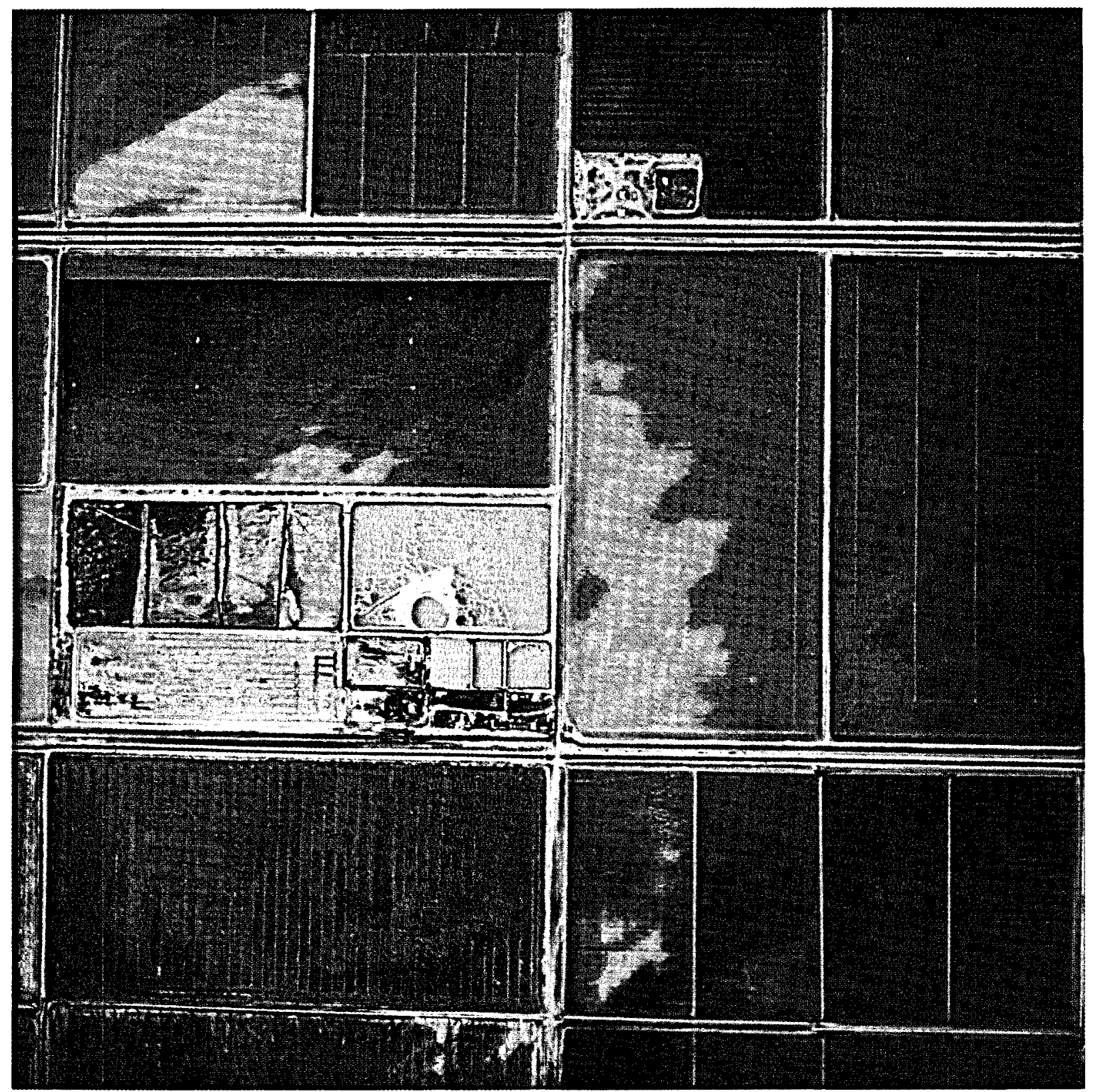

Fig. 3. A partial example (false color) of multispectral imagery of the Sinclair $\$$ 作 geothermal well site near Niland, California. Prominent features are the brine holding ponds (middle left) and agricultural crops (lower right). The patchy appearance of agricultural crops is typical of the Valley and is generally due to salt accumulation problems caused by poor drainage. 
geothermal sites this year.

Additional multispectral imaging

will be taken on a one-time basis

of a known fault location, a known brine spill, and a known cropdamage location for the purpose of providing reference data on known areas. 




\section{RESEARCH SUPPORT CONTRACTS}

Thomas D. Palmer

\section{Research Support Contracts}

The following summarizes IVEP research-support contracts totaling $\$ 467,800$ that are currently placed with various universities and government agencies as ERDA-designated "directed procurements." These contracts were placed during FY 1976, but most of the work will be done in FY 1977. We anticipate that several additional research-support contract will be placed in 1977.

\section{Air Quality}

Characterization of airborne particulates throughout the Imperial Valley area.

Calibration and standardization of air-quality analytical equipment and gases.

Manpower assistance for air-quality monitoring stations.

\section{Subsidence/Seismicity Effects}

Establishment of a subsidence-monitoring network around the SDG\&E/ERDA Test Facility.

Installation of a 6-station seismic-monitoring network around the Salton Sea Geothermal Field.

Resurvey of the Imperial Valley Subsidence Detection Network. (This represents a contribution to a large network, which is also funded by government agencies and private developers.)
University of

California/Davis

\$100K

State of California

Air and Industrial

Hygiene Laboratory

$$
\$ 25 \mathrm{~K}
$$

County of Imperial

\$16K

County of Imperial

$\$ 12 \mathrm{~K}$

U.S. Geological

Survey

$\$ 69 \mathrm{~K}$

State of California

Division of $0 i 1$ and

Gas

$\$ 35 \mathrm{~K}$ 
Fiscal impacts in Imperial County due to geothermal development$$
\text { a }
$$

Leadership, community decisions, and geothermal energy development: Imperial County.

Analysis of Salton Sea recreational uses and potentlal impacts from local geothermal development.

Ecosystem Quality

Analysis of solute movement in soils following geothermal brine spills.

Analysis of Pileworm-larval success at elevated Salton Sea salinity.

Analysis of Yuma clapper Rail ecology for Imperial Valley geothermal areas.

Analysis of geothermal pollutant effects upon honeybee production and mortality.

Supplemental fumigation studies of geothermal pollutant effects on Imperial Valley crops.

Analysis of Imperial valley crop-water use and a regional comparison.

Trace-metal speciation of geothermal brine following contamination of soils.
University of Califor-

nia, Berkeley

\$16K

University of

California, Riverside $\$ 20 \mathrm{~K}$

University of

California, Berkeley

$\$ 7.6 \mathrm{~K}$

University of

California, Riverside

$\$ 15 \mathrm{~K}$

Pomona College

$\$ 10 \mathrm{~K}$

Arizona State

University

$\$ 10 \mathrm{~K}$

University of

California, Riverside

$\$ 5 \mathrm{~K}$

University of

California, Riverside:

$\$ 10 \mathrm{~K}$

University of

California, Davis

$\$ 3.2 \mathrm{~K}$

University of

California, Riverside

$\$ 15 \mathrm{~K}$ 
Effects on w11d1ife-refuge areas from geothermal development activities, particularly noise

Analysis of Imperial Valley evapotranspiration and crop ecology.

Fish-sampling program in Salton Sea area for baseline characterization.

Analysis of effects from geothermal power-plant effluents on Salton Sea organisms.

Imperial Valley crop sampling for baseline characterization.

Evaluation of toxicity from geothermal brines and pollutants to Gambusia affinis.

Evaluation of the synergistic effects of hydrogen sulfide, carbon dioxide, and ozone on Imperial Valley crop yields.

Workshop on potential ecological problems and needed research in Imperial Valley.
St. Mary's College, Moraga

$\$ 19 \mathrm{~K}$

U.S. Dept. Agriculture Brawley Research

Station

$\$ 10 \mathrm{~K}$

State of California

Department of Fish \& Game

$\$ 4.6 \mathrm{~K}$

California State

College, Hayward

$\$ 26 \mathrm{~K}$

State of California

Agricultural Extension

Service

$\$ 9.8 \mathrm{~K}$

North Carolina

Centra1 University

$\$ 10 \mathrm{~K}$

University of

California, Davis

$\$ 9.9 \mathrm{~K}$

University of

California, Riverside

$\$ 9.7 \mathrm{~K}$ 


\section{Imperial Valley Environmental Project}

Advisory Panel 


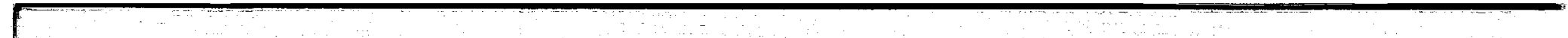




\title{
Imperial Valley Environmental Project Advisory Panel
}

\author{
Lynn R. Anspaugh
}

INTRODUCTION

During initial planning for the Imperial Valley Environmental Project (IVEP), it was strongly recommended by the funding agency, the Energy Research and Development Administration, that an Advisory Pane1 be established. LLL management agreed and esțablished such a panel. It reports to Dr. Roger Batzel, Director of the Laboratory, through Dr. Mortimer Mendelsohn, Laboratory Program Director for Biomedical and Environmental Research. It was agreed that the Panel would have four primary

functions:

- Review the research plans for adequacy and relevance,

- Monitor the progress of the research,

- Provide a mechanism for Informing other agencies of detailed research plans and results in a timely fashion, and

- Serve as a focus of coordination to avoid needless duplication of effort.

\section{PANEL SELECTION}

An at tempt was made to select

Panel members from organizations who had already established geothermal programs in Imperial County, who have specific regulatory or general environmental responsibilities in Imperial Valley, who had already established applicable environmental programs related to geothermal energy, or who have general interests in the energy and environment area. Because we desired to have a relatively small interactive group, designated individuals were requested to represent all the interests of their parent organizations.

Early in CY 1976, letters were sent to the following individuals requesting that they either serve on the Advisory Panel or name a representative.

Dr. James L. Liverman

Assistant Administrator for

$\vartheta$ Ervironment and Safety

Energy Research and Development Administration

Washington, D.C.

Dr. Wilson K. Talley.

Assistant Administrator for Research and Development Environmental Protection Agency Washington, D.C.

Dr. Cyril L. Comar

Director, Environmenta1 Assessment Department

Electric Power Research Institute Palo Alto, California

Mr. Willard M. Spaulding, Jr.

Nationa1 Geothermal Environmenta1 Advisor

U.S. Fish and Wildlife Service

Sacramento, California; 
Dr. Claire T. Dedrick

Secretary for Resources

State of California

Sacramento, California

Mr. J. B. Moore

Vice President, Advanced Engineering

Southern California Edison Company

Rosemead, California

Mr. Joseph F. Dietz

Manager, Environmental

Coordination

San Diego Gas \& Electric Company

San Diego, California

Mr. David E. Pierson

Director of Public Works

County of Imperial

E1 Centro, California

Mr. Michael McCloskey

Executive Director

Sierra Club

San Francisco, California

Mr. Reid T. Stone

Area Geothermal Supervisor

U.S. Geological Survey

Menlo Park, California

Mr. Loyd H. Forrest

Executive Director

Energy Resources Conservation and Development Commission

State of California

Sacramento, California

Dr. Ralph Perhac

Program Manager

Advanced Environmental Research and Technology

National Science Foundation

Washington, D.C.

\section{FIRST ADVISORY PANEL MEETING}

The first meeting of the Advisory Panel was held on April 15, 1976, at the Lawrence Livermore Laboratory in Livermore, California. The specific purposes of this first meeting were to review the research plans for the
IVEP and to achieve a better coordination of the research of several organizations with overlapping interests and goals.

Those attending the first Panel meeting were

\section{Pane1 Members}

Mr. David E. Pierson, Chairman (pro tem)

Director of Public Works

County of Imperial

E1 Centro, California

Mr. James W. Burns

Assistant to the Secretary

The Resources Agency

State of California

Sacramento, California

Dr. Sie Ling Chiang

Chief, Environmental and Safety Section

Conservation Division

U.S. Geological Survey

Menlo Park, California

Mr. E. Ross Deter

Senior Environmental Planner

Energy Resources Conservation and Development Commission

Sacramento, California

Mr. Joseph F. Dietz

Manager, Environmental Coordination

San Diego Gas \& Electric Company

San Diego, California

(Mr. Dietz also represented the Geothermal Resources Council.)

Dr. Ralph Perhac

Program Manager

Advanced Environmental Research and Technology

Nationa1 Science Foundation

Washington, D.C.

(Dr. Perhac also represented the Electric Power Research Institute, his present employer.) 
Mr. Willard M. Spaulding, Jr.

National Geothermal Environmental Advisor

U.S. Fish and Wildlife Service

Sacramento, California

Dr. Ian Straughan

Environmental Investigations

Section

Research and Development Office.

Southern California Edison Company

Rosemead, California

Mr. Hodge $\mathrm{R}$. Wasson

Acting Manager, Geotherma1/Solar

Division of Technology Overview

Energy Research and Development Administration

Washington, D.C.

Dr. G. Bruce Wiersma

Chief, Pollutant Pathways Branch

Environmental Monitoring and

Support Laboratory

Environmental Protection Agency

Las Vegas, Nevada

Panel Alternates

Dr. Douglas A. James

Environmental Programs

Division of Biomedical and

Environmental Research

Energy Research and Development Administration

Washington, D.C.

Mr. Ronald R. Loose

Chief, Environmental Studies Branch

Division of Geothermal Energy

Energy Research and Development Administration

Washington, D.C.

Mr. Gary B. Stacey

Region V

Department of Fish and Game

State of California

Long Beach, California

Mr. Reid T. Stone

Area Geothermal Supervisor

Conservation Division

U.S. Geological Survey

Menlo Park, California

\section{Observers}

Mr. Perry L. Herrgesell

Region V.

Department of Fish and Game

9. State of California

Long Beach, California

Mr. Lowell A. Miller

Environment and Safety Division

Energy Research and Development Administration

San Francisco, Calïfornia

Mr.W.J. O'Brien

Manager, Technology Overview

Environment and Safety Group

The Aerospace Corporation

Germantown, Maryland

Mr. Car1 M. York

Consultant (Under contract to ERDA)

Oakland, California

The Sierra Club had nominated

Professor Hamilton Hess to serve on

the Advisory Panel. However,

Professor Hess, who volunteers his

time for Sierra Club activities,

subsequently declined to serve

because of conflicting commitments.

Professor Philip R. Pryde of San

Diego State University was then

designated, but at a date too late to

attend the April 15 meeting.

The agenda for the first Panel

meeting included presentations by all

leaders of the IVEP and an Executive

Session where Panel Members were

invited to provide candid comments.

The comments were generally favorable to the Project, but many con-

structive criticisms were also

received. Concern was expressed that

the overall image of the Project is 
negative with too much emphasis on possible adverse impacts and not enough on the positive impacts of geothermal development. In particular, it was recommended that the Project move positively to facilitate the achievement of beneficial impacts. Concern was also expressed that there was too much emphasis on the Salton Sea and peripheral issues at the expense of the agricultural system including the critical issues of water quantity and quality. The Panel recommended that more attention be given to quality assurance efforts and to validation of models. Both the Socioeconomic Effects and the
Integrated Assessment programs were criticized as being unfocused and unbounded. Numerous more specific recommendations were also provided by the Panel.

LLL management has responded by implementing many of the recommendations. Quality-assurance efforts have been expanded, and beneficial possibilities of geothermal development are being emphasized. Management changes have taken place in both the Socioeconomic Effects and Integrated Assessment programs, although not as a direct result of the Panel's recommendations. 


\section{Imperial Valley Environmental Project}

Schedule 


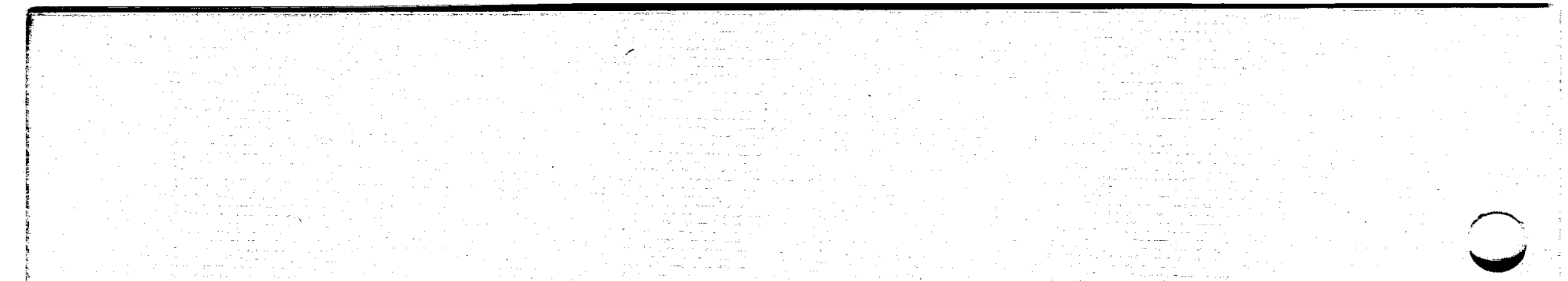




\section{Imperial Valley Environmental Project Schedule}

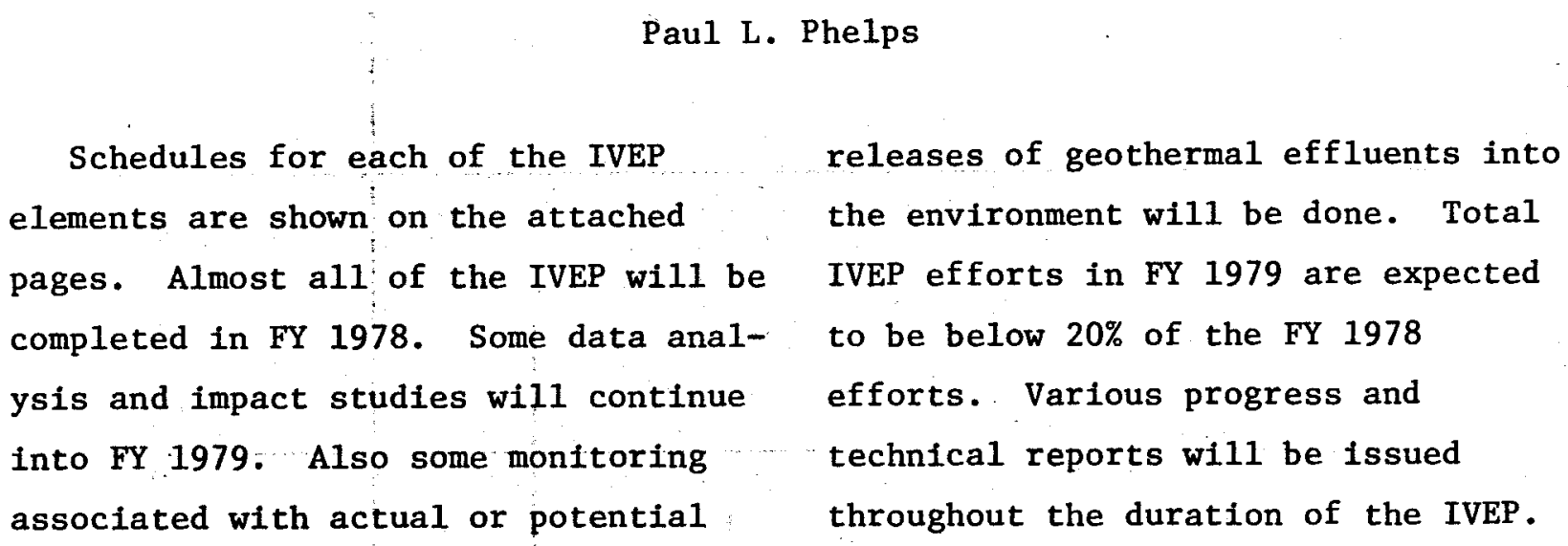

$\mathrm{BKI} / \mathrm{gw} / \mathrm{vt}$ 


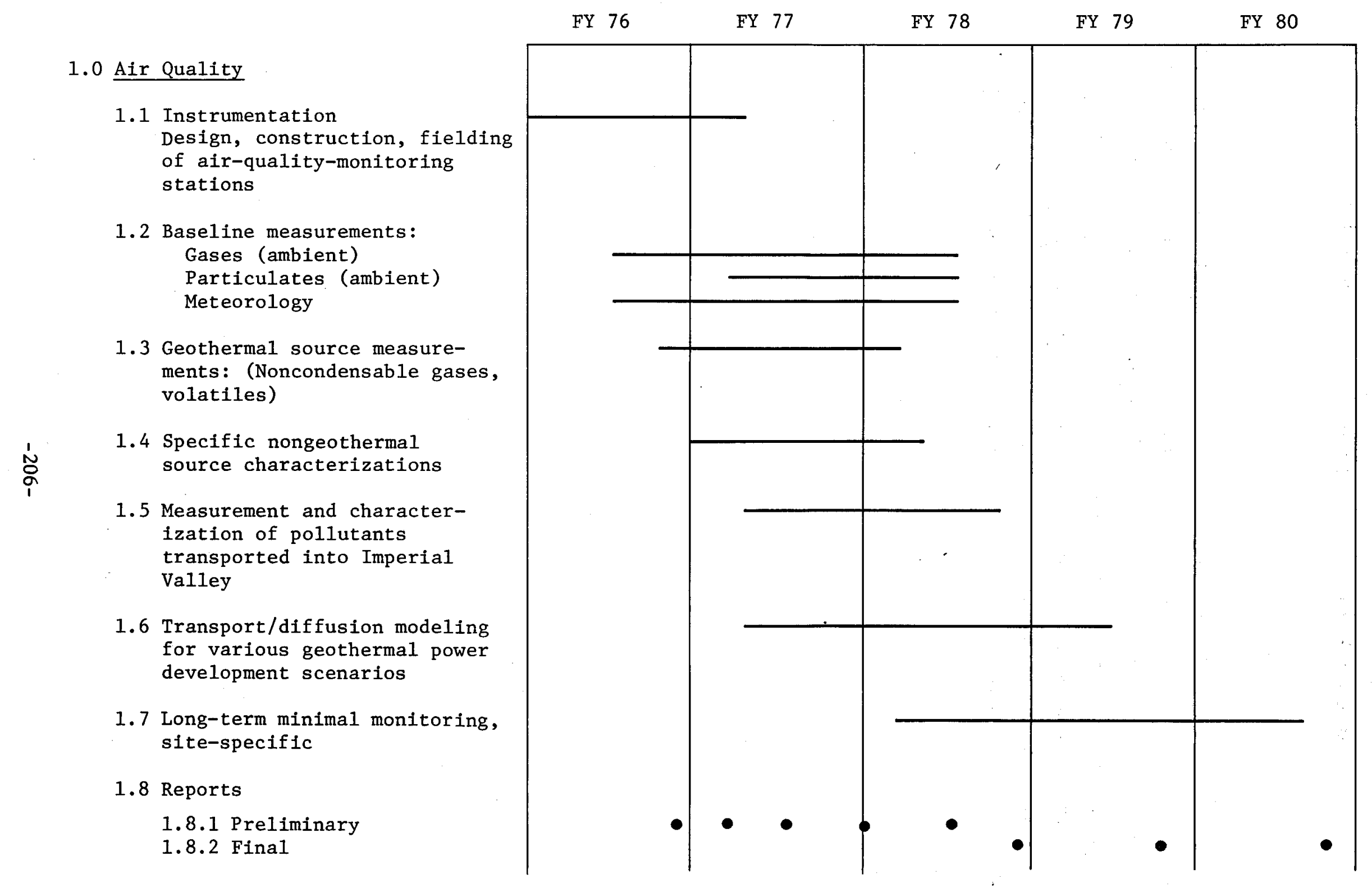



FY 76 FY 78 FY 79

2.0 Water Quality (Continued)

2.2 Evaluation of impacts from water management options for cooling towers and injection

2.3 Reports

2.3.1 Preifminary

2.3. 2 Final

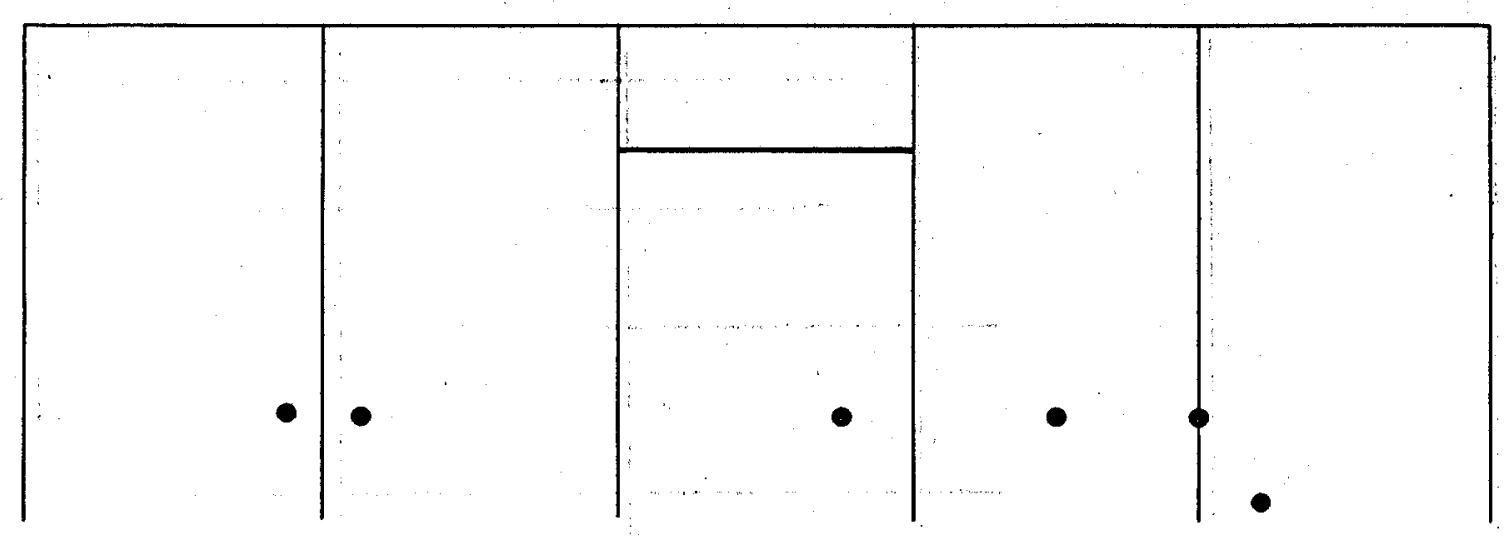




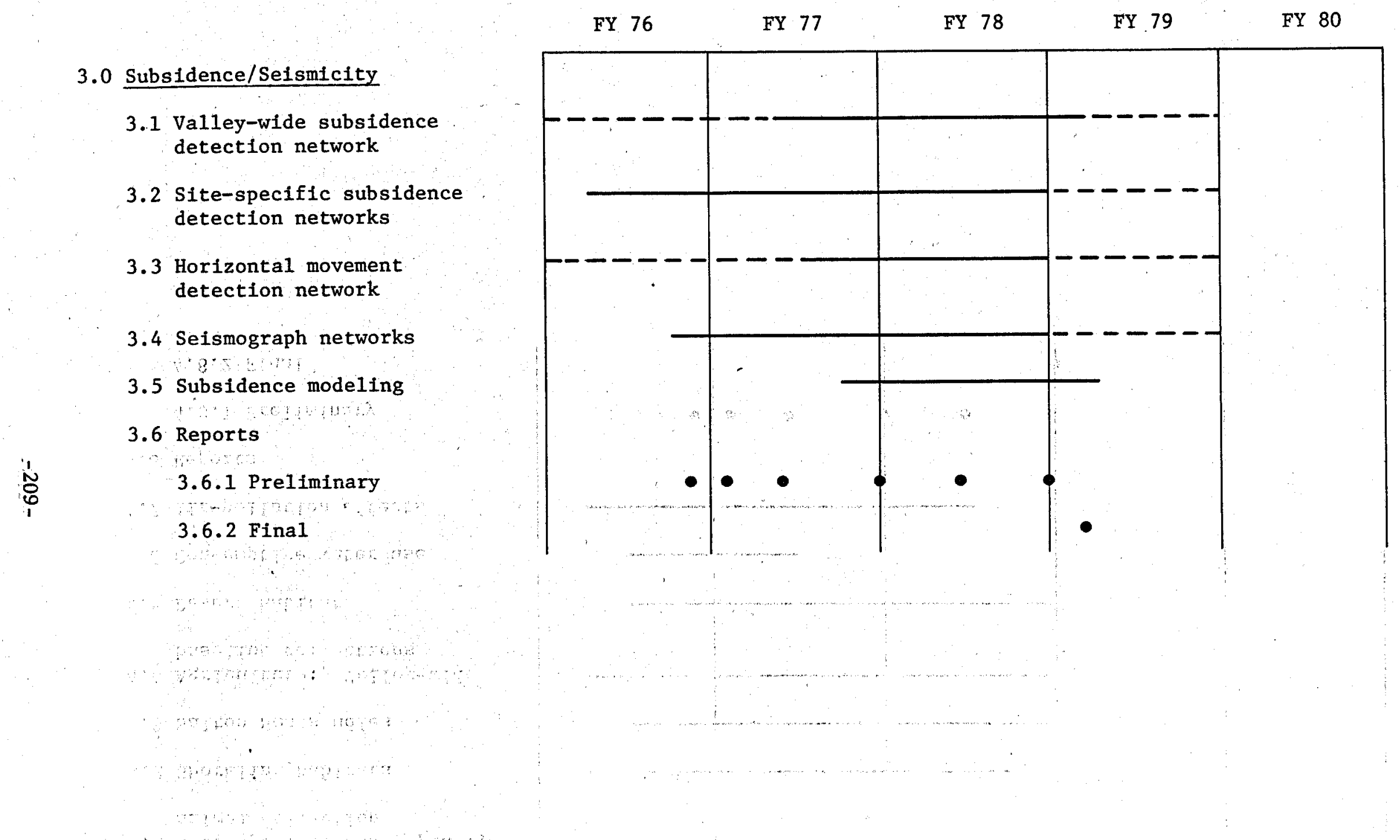


4.0 Ecosystem Quality

4.1 Site-specific soil, plant, animal collection

4.2 Shoreline habitats

4.3 Salton Sea studies

4.4 Agriculture: Valley-wide baseline collections

4.5 Desert habitat

4.6 Consumptive water use

$\stackrel{1}{0}$

\subsection{Reports}

4.8.1 Preliminary

4.8.2 Final

FY 76

FY 77

FY 79

FY 80

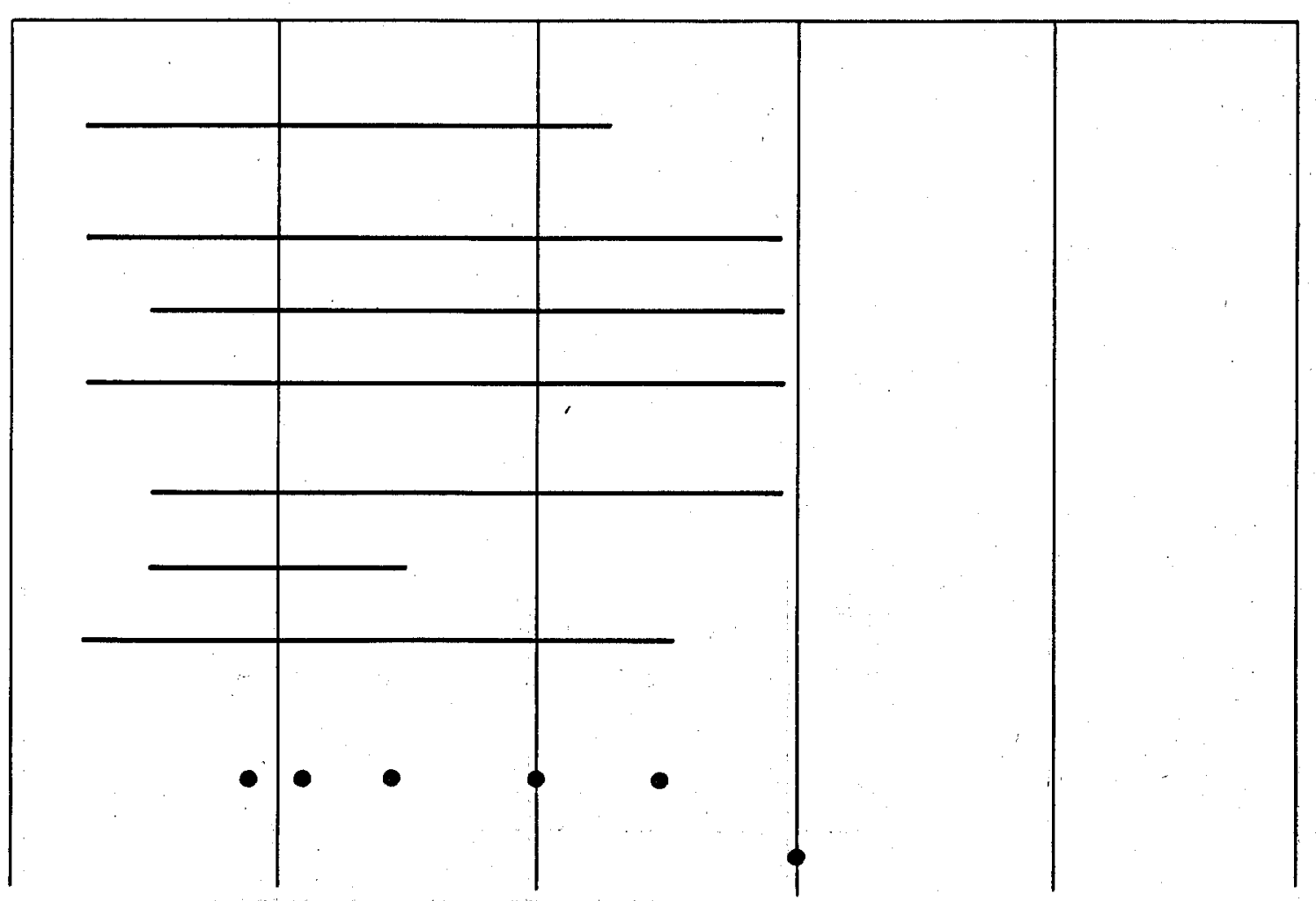




\subsection{Socioeconomics}

5.1 Imperial Va1ley fiscal, economic, social, and energy-systems

characterizations

\subsection{Initial development} scenarios

\subsection{Recreation study}

5.4 Service-demands study

5.5 Tax study

\subsection{Reports}

5.6.1 Preliminary

5.6 .2 Final

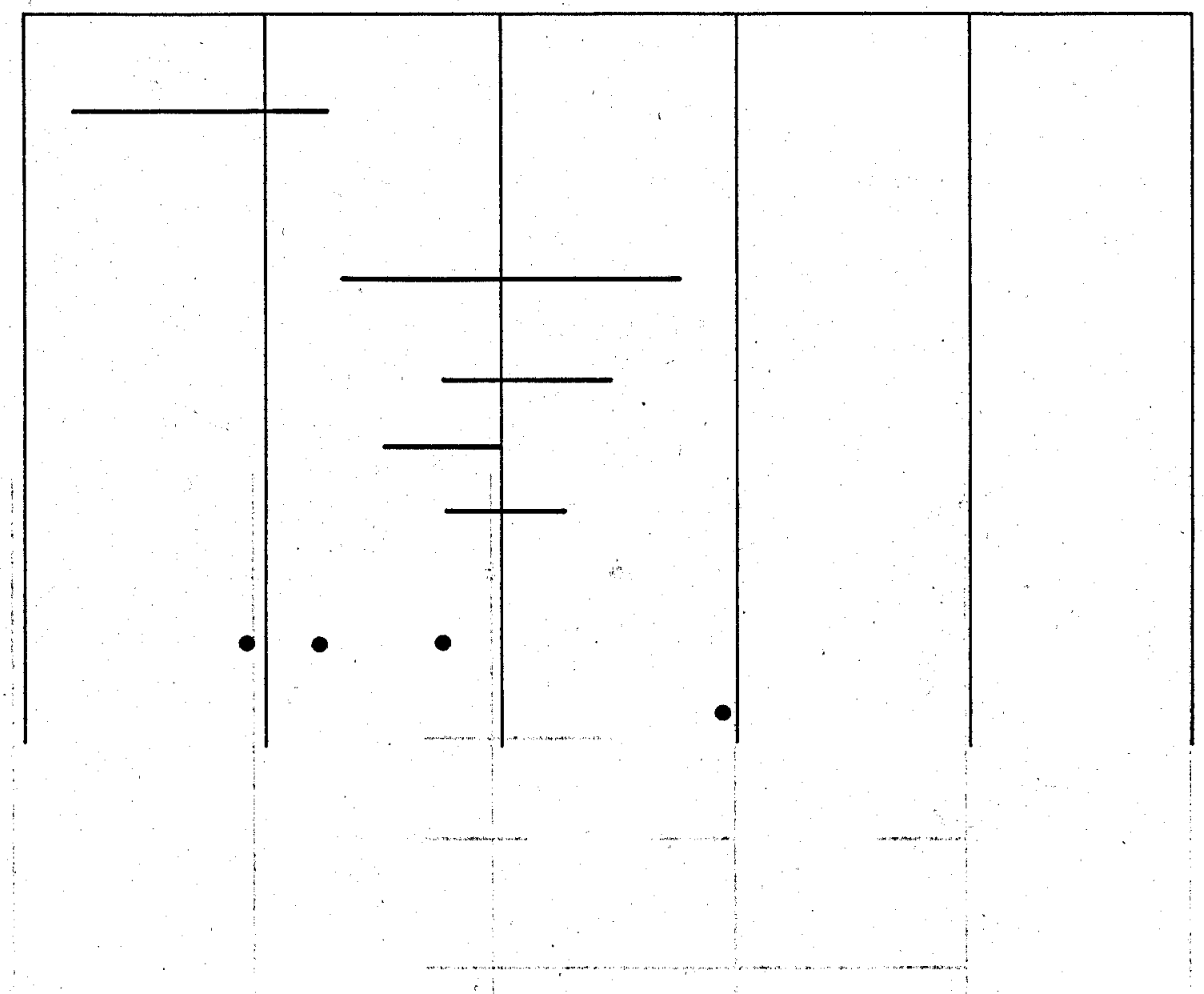




\subsection{Health Effects}

6.1 Ranking of pollutants: Possible health effects Dose-response curves

6.2 Set up and maintain exemplary Health Statistics Program in Imperial Valley

6.3 Conduct communityresponse surveys

6.4 Review occupational health programs

\subsection{Reports}

\subsubsection{Preliminary 6.5 .2 Final}

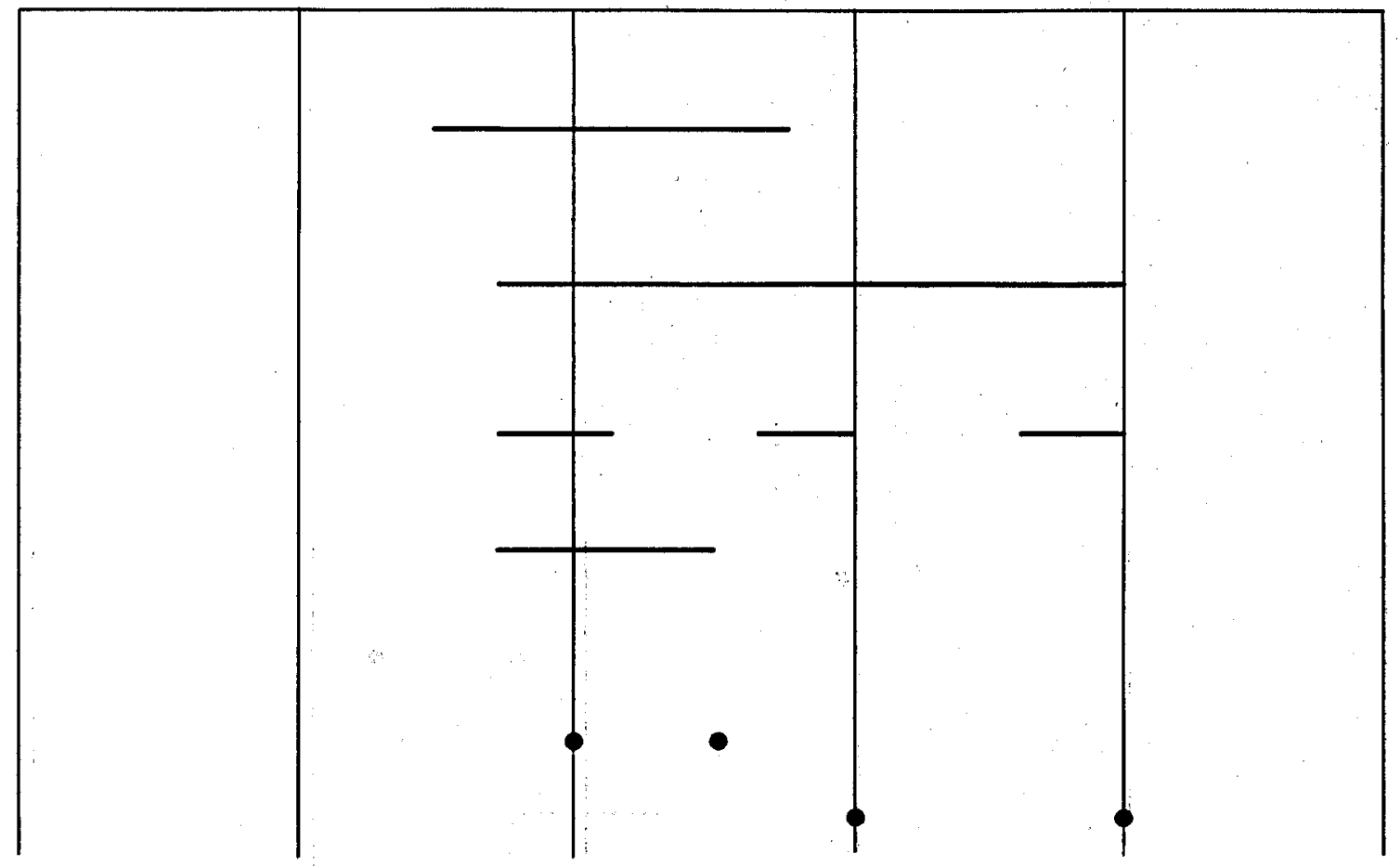




\subsection{Integrated Assessment}

7.1 Describe the Imperial Valley System from existing data

7.2 Develop geothermal energy scenarios for the Imperial Valley

7.3 Establish an informationmanagement system for existing and future information and data transfer

7.4 Develop a crop model of photosynthesis, growth, and yield as a function of environmenta1 variables and gaseous pollutants

7.5 Compare the effectivenes of federal and state geothermal lease laws on resource development

7.6 Atmospheric mode 1 . modification for Imperial Valley

7.7 Evaluate air-pollutant changes in the Imperial Valley due to proposed geothermal development

FY 76

FY 78

FY 79

FY 80

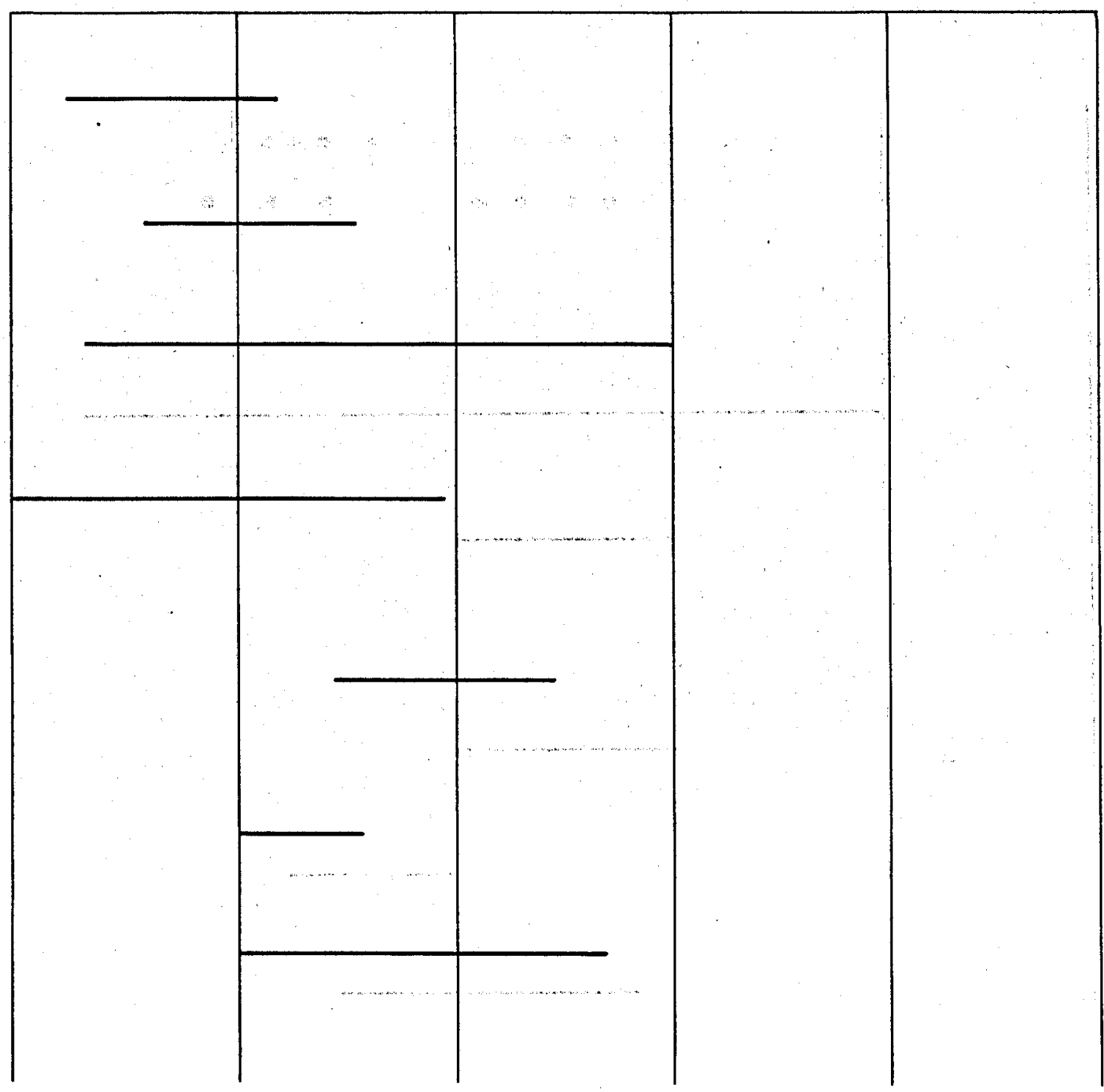




\subsection{Integrated Assessment (Continued)}

7.8 Analyze the legal and institutional constraints on geothermal development

7.9 Assess the impacts of alternative water-management plans

7.10 Perform an integrated assessment of geothermal energy development in the Imperial Valley using the results of the various research programs

7.11 Assess the impacts of a major accident (e.g., well blowout, brine spili)

7.12 Transfer assessment information to decisionmakers (county, state, and federal) and developers

7.13 Reports

\subsubsection{Preliminary}

7.13.2 Final

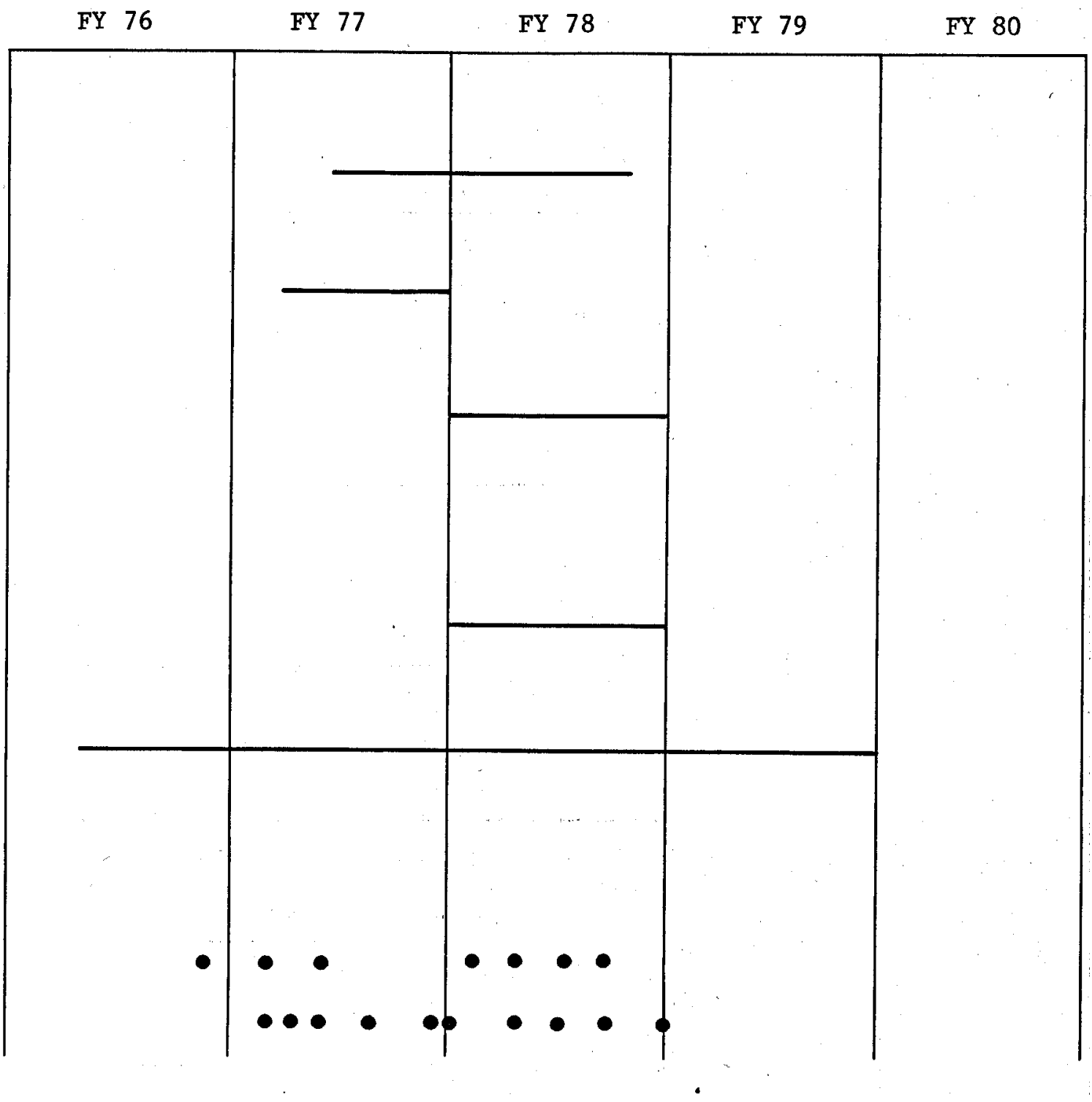

